Ground Stress in Mining (Part 1):

Measurements and Observations at Two Western U.S. Longwall Mines

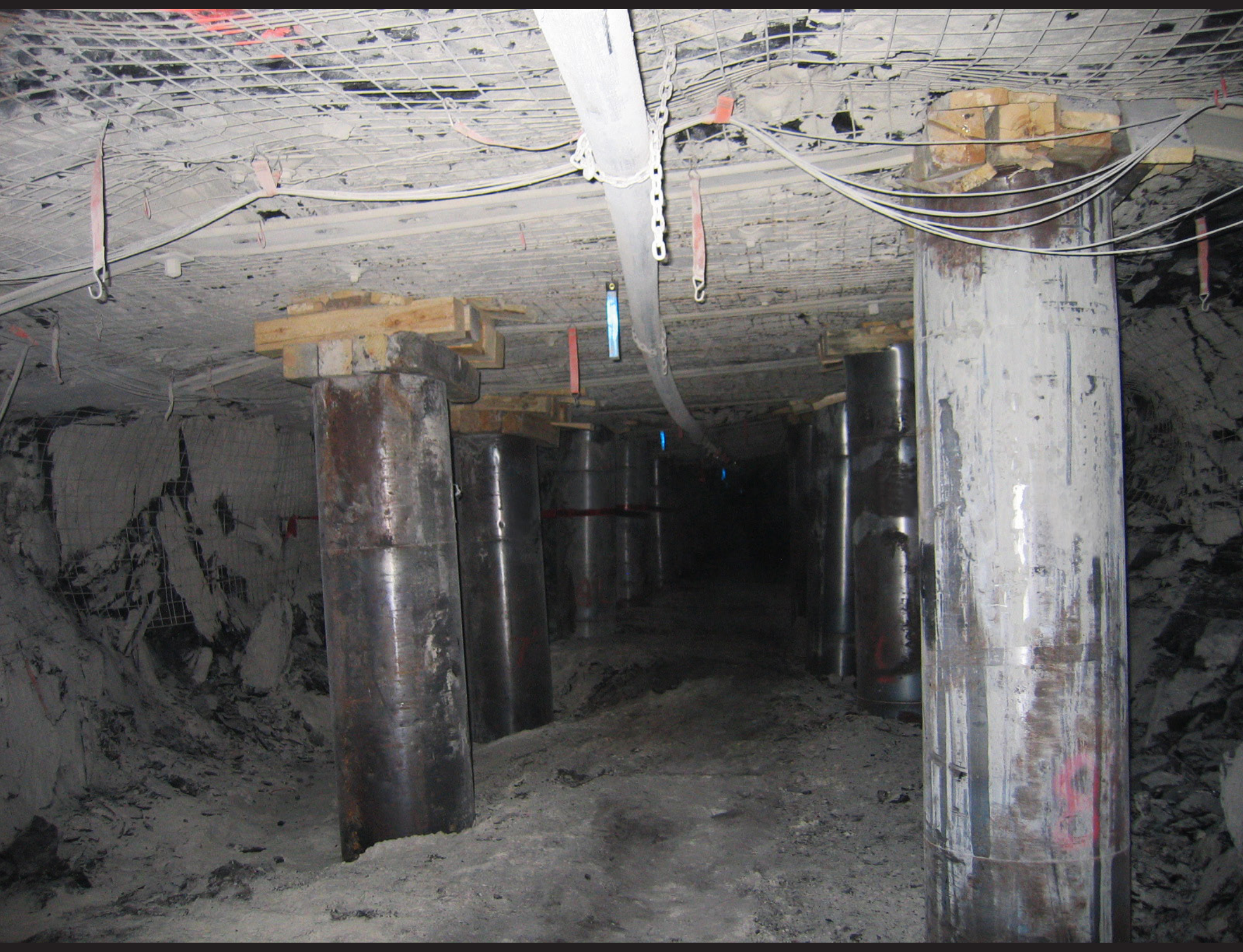


Report of Investigations 9702

Ground Stress in Mining (Part 1): Measurements and Observations at Two Western U.S. Longwall Mines

Mark K. Larson, Heather E. Lawson, Eric G. Zahl, and Tristan H. Jones 


\section{This document is in the public domain and may be freely copied or reprinted.}

\section{Disclaimer}

Mention of any company or product does not constitute endorsement by the National Institute for Occupational Safety and Health (NIOSH). In addition, citations to websites external to NIOSH do not constitute NIOSH endorsement of the sponsoring organizations or their programs or products.

Furthermore, NIOSH is not responsible for the content of these websites. All web addresses referenced in this document were accessible as of the publication date.

\section{Get More Information}

Find NIOSH products and get answers to workplace safety and health questions:

1-800-CDC-INFO (1-800-232-4636) | TTY: 1-888-232-6348

CDC/NIOSH INFO: cdc.gov/info | cdc.gov/niosh

Monthly NIOSH eNews: cdc.gov/niosh/eNews

\section{Suggested Citation}

NIOSH [2020]. Ground stress in mining (part 1): measurements and observations at two Western U.S. longwall mines. By Larson MK, Lawson HE, Zahl EG, Jones TH. Spokane, WA: U.S. Department of Health and Human Services, Centers for Disease Control and Prevention, National Institute for Occupational Safety and Health, DHHS (NIOSH) Publication No. 2020-103, RI 9702.

https://doi.org/10.26616/NIOSHPUB2020103

DOI:https://doi.org/10.26616/NIOSHPUB2020103

DHHS (NIOSH) Publication No. 2020-103

January 2020

Front cover photo by NIOSH. 


\section{Table of Contents}

ABSTRACT
INTRODUCTION
FIELD SITE DESCRIPTION
MINE A
MINE B
OBSERVATIONS
MINE A
MINE B
MINE A
MEASUREMENTS
MINE A

DISTANCE TO FIRST DETECTION OF MINING-INDUCED

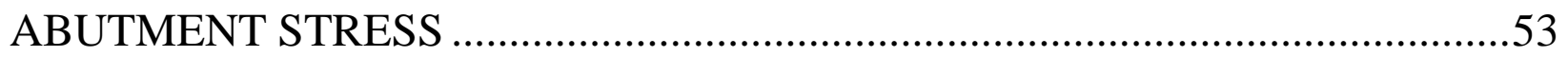

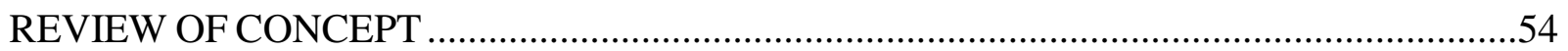

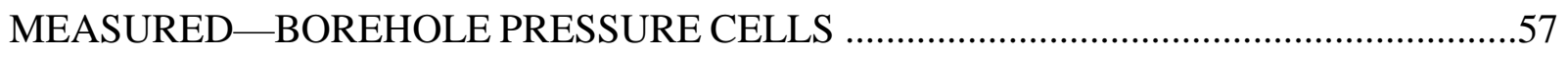

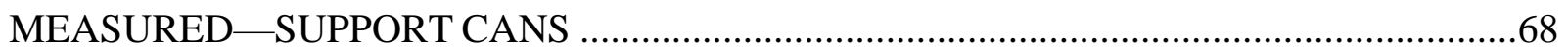

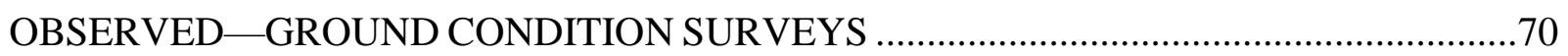

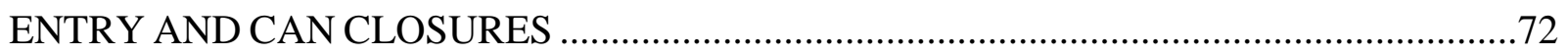

SUMMARY OF FIRST DETECTION OF FIRST ARRIVAL OF MINING-INDUCED

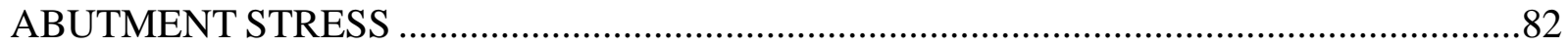

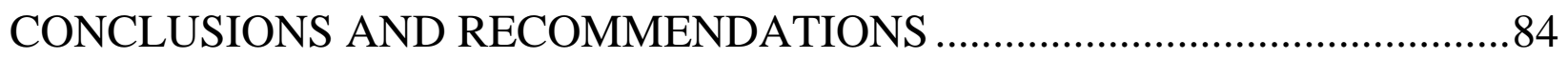

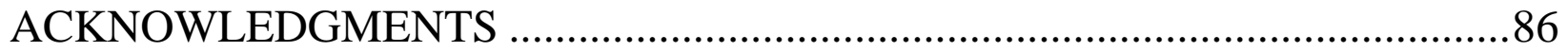

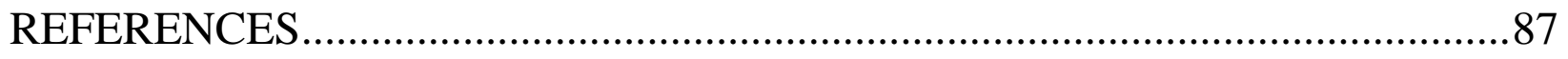

APPENDIX A: MINE A-BOREHOLE PRESSURE CELL

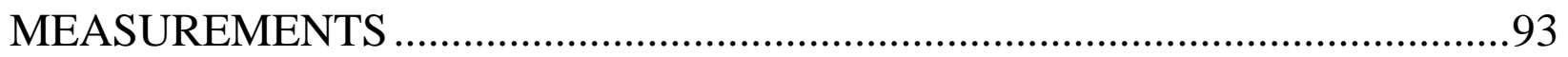

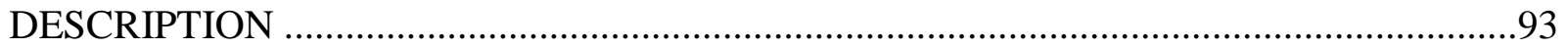

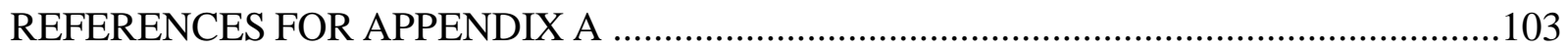

APPENDIX B: MINE A—SUPPORT CAN MEASUREMENTS .......................105 
DESCRIPTION 105

APPENDIX C: MINE A-ENTRY CLOSURE AND ROOF SAG MEASUREMENTS 109

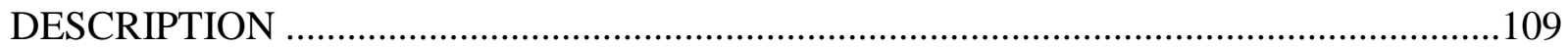

APPENDIX D: MINE A —GROUND CONDITION SURVEYS ........................125

DESCRIPTION .125

APPENDIX E: MINE B-BOREHOLE PRESSURE CELL MEASUREMENTS

DESCRIPTION

EXPERIENCE AND FACTORS CONTRIBUTING TO DECREASE IN

MEASUREMENT QUALITY

MEASUREMENTS. 134

REFERENCES FOR APPENDIX E 140

APPENDIX F: MINE B-SUPPORT CAN LOAD MEASUREMENTS 141 DESCRIPTION 141

APPENDIX G: MINE B-ENTRY CLOSURE MEASUREMENTS 143 DESCRIPTION

APPENDIX H: MINE B-MISCELLANEOUS MEASUREMENTS: GROUND CONDITION SURVEYS, AND ROOF AND RIB EXTENSOMETERS.

DESCRIPTION 


\section{Figures}

Figure 1. Distribution of overpanel weight for supercritical and subcritical panels......................3

Figure 2. Generalized stratigraphic column provided by Mine A ..............................................8

Figure 3. Mine map of Mine A with overlain mapped and projected faulting ............................9

Figure 4. A stratigraphic column constructed from core taken in the B-12 headgate at crosscut 23 in Mine B

Figure 5. The locations of instrument sites in the B-11 and B-12 panel gate roads at Mine B

Figure 6. Fence diagrams of near-seam stratigraphic structure at Mine A, determined from geophysical logs of gob vent boreholes .16

Figure 7. Sample photograph of rating 3 roof deterioration .20

Figure 8. Sample photograph of rating 1.5 rib deterioration ................................................20

Figure 9. Sample photograph of rating 4 floor heave

Figure 10 . View of entry 3 at crosscut 10 in 1 North, showing a typical 1 North condition of no significant floor heave

Figure 11 . View of entry 2 at crosscut 30 in 2 North, showing typical floor heave as the face approached .22

Figure 12. Instrumentation as installed at the 1 North inby site. .26

Figure 13. Enclosure with Campbell Scientific 21XQM datalogger and components for reading BPC pressure transducers and the string potentiometers of roof extensometers

Figure 14. Hydraulic lines, manifolds, hydraulic gauges, pressure transducers, and cabling installed on the rib near the collars of BPC boreholes at the 2 North inby site

Figure 15. Instrumentation as installed at the 2 North inby site ............................................28

Figure 16. Instrumentation as installed at the 1 North outby site

Figure 17. Installed three-point roof extensometer (indicated with blue arrow) with string potentiometers mounted on red collar brackets that are partially covered with rock dust .30

Figure 18. Instrumentation as installed at the 2 North outby site

Figure 19. The 2 North outby instrumentation site at Mine A showing locations of instrumented support Cans and their labels identified in zoomed-in sketches

Figure 20. Map showing detail of instruments installed at the T39 station in the tailgate of the B-12 panel at Mine B

Figure 21. Map showing detail of instruments installed at the T33 and T34 stations in the tailgate of the B-12 panel

Figure 22. Map showing detail of instruments installed at the T20 and T21 stations in the tailgate of the B-12 panel. 
Figure 23. Map showing detail of instruments installed at the $\mathrm{H} 42$ and $\mathrm{H} 43$ stations in the headgate of the B-12 panel

Figure 24. Map showing detail of instruments installed at the H21 and H22 stations in the headgate of the B-12 panel

Figure 25. Cell pressure of BPCs in barrier pillar with distance from face at the 1 North outby instrument station.

Figure 26. Cell pressure of BPCs in south pillar with distance from face at the 1 North outby instrument station.

Figure 27. Cell pressure of BPCs in north pillar with distance from face at the 1 North outby instrument station

Figure 28. Cell pressure of BPCs in south pillar with distance from face at the 2 North outby instrument station...

Figure 29. Cell pressure of BPCs in north pillar with distance from face at the 2 North outby instrument station

Figure 30. Cell pressure of BPCs in barrier pillar with distance from face at the 2 North outby instrument station

Figure 31. Load increase versus distance from face on support Cans in entry 3 at crosscut 10 in 2 North during mining of Panel 1

Figure 32. Load increase versus distance from face on support Cans in entry 3 between crosscuts 9 and 10 in 2 North during mining of Panel 1 .

Figure 33. Deterioration ratings between crosscuts 8 and 9, entry 2, in 1 North, an instrumented location relative to the longwall face .46

Figure 34. Changing index ratings in the roof, ribs, and floor in the 2 North gate roads during Panel 1 mining in entry 2 between crosscuts 11 and 12

Figure 35. Buckling failure of the type observed in the 2 North gate road.

Figure 36 . The varying index ratings in the roof, ribs, and floor in an anomalous zone near crosscut 24 in entry 2 of the 2 North gate roads during Panel 1 mining

Figure 37. BPC pressure versus distance to the face of instruments at the T21 site in entry 3 of the B-12 panel tailgate at Mine B

Figure 38. BPC pressure versus distance to the face of instruments at the H22 site in entry 3 of the B-12 panel headgate at Mine B

Figure 39. Outby support Can load with distance to the face in entry 3 at the H21 site in the B-12 panel headgate at Mine B

Figure 40. Entry and roof-to-Can midheight closures versus distance to face at the T34 and T20 sites in the B-12 tailgate

Figure 41. Measured load transfer distance versus seam depth for several cases in the eastern United States 
Figure 42. Typical raw BPC pressure versus location of longwall face with respect to the $\mathrm{BPC}$ instrument line.

Figure 43. Relative position of BPCs in 1 North when the stress-increase threshold was reached

Figure 44. Relative position of BPCs in 2 North when stress-increase threshold was reached

Figure 45. BPC in the pillar at $14.0 \mathrm{~m}$ (46 ft) with distance from face at T21 site at Mine B

Figure 46. BPC in the pillar at $3.7 \mathrm{~m} \mathrm{(12} \mathrm{ft)} \mathrm{with} \mathrm{distance} \mathrm{from} \mathrm{face} \mathrm{at} \mathrm{T21} \mathrm{site} \mathrm{at} \mathrm{Mine} \mathrm{B} \mathrm{.......63}$

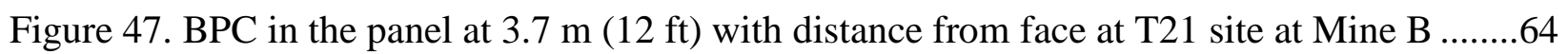

Figure 48. BPC in the pillar at $14.6 \mathrm{~m} \mathrm{(48} \mathrm{ft)} \mathrm{with} \mathrm{distance} \mathrm{from} \mathrm{face} \mathrm{at} \mathrm{H} 22$ site at Mine B

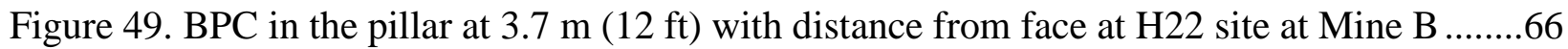

Figure 50. BPC in the panel at $3.7 \mathrm{~m}(12 \mathrm{ft})$ with distance from face at $\mathrm{H} 22$ site at Mine B.......66

Figure 51. Relative position of support Cans along with BPCs in 2 North when the load-increase threshold was reached.

Figure 52. Load on outby support Can at $\mathrm{H} 21$ at Mine B, indicating the distance from face at which first arrival of mining-induced abutment stress was detected .70

Figure 53. Relative range, with respect to the face within which a ground condition rating increased, indicating the arrival of abutment load in 1 North.

Figure 54. Relative range, with respect to the face within which a ground condition rating increased, indicating the arrival of abutment load in 2 North.

Figure 55. Closure at support Cans and at roof-to-floor measurement points in 2 North, entry 3 , at crosscut 10 at Mine A

Figure 56. Closure at support Cans and at roof-to-floor measurement points in 2 North, entry 3, at mid-pillar between crosscuts 9 and 10 at Mine A

Figure 57. Closure rates at support Cans and at roof-to-floor measurement points in 2

North, entry 3, at mid-pillar between crosscuts 9 and 10 at Mine A

Figure 58. Zoomed-in view of initial closure at support Cans and at roof-to-floor measurement points in 2 North, entry 3, at crosscut 10 at Mine A

Figure 59. Zoomed-in view of initial closure at support Cans and at roof-to-floor measurement points in 2 North, entry 3, at mid-pillar between crosscuts 9 and 10 at Mine A .76

Figure 60. Initial part of select curves of Can and roof-to-floor closures versus face position at mid-pillar in entry 3, at crosscut 10 in 2 North at Mine A .77

Figure 61. Initial part of select curves of Can and roof-to-floor closures versus face position at mid-pillar in entry 3, between crosscuts 9 and 10 in 2 North at Mine A 
Figure 62. Relative position of BPCs, support Cans, range of ground condition, and closure meters in 2 North at Mine A when the threshold for first arrival of abutment stress was reached

Figure 63. Closure of entry with distance to face at inby T34 site at Mine B

Figure 64. Closure of Can (roof to mid-height of Can) with distance to face at inby T34 site at Mine B

Figure 65. Closure of Can (roof to mid-height of Can) with distance to face at outby T20 site at Mine B .81

Figure 66. Closure of entry with distance to face at outby T20 site at Mine B

Figure A1. BPC pressures with time for cells in barrier pillar of 1 North inby site during

Panel 1 retreat at Mine A

Figure A2. BPC pressures with time for cells in south pillar of 1 North inby site during

Panel 1 retreat at Mine A

Figure A3. BPC pressures with time for cells in north pillar of 1 North inby site during Panel 1 retreat at Mine A

Figure A4. BPC pressures with time for cells in south pillar of 2 North inby site during

Panel 1 retreat at Mine $\mathrm{A}$

Figure A5. BPC pressures with time for cells in north pillar of 2 North inby site during

Panel 1 retreat at Mine A

Figure A6. BPC pressures with time for cells in barrier pillar of 2 North inby site during

Panel 1 retreat at Mine A

Figure A7. BPC pressures with time for cells in south pillar of 2 North inby site during

Panel 2 retreat at Mine A

Figure A8. BPC pressures with time for cells in north pillar of 2 North inby site during Panel 2 retreat at Mine A

Figure A9. BPC pressures with time for cells in barrier pillar of 2 North inby site during

Panel 2 retreat at Mine A

Figure A10. BPC pressures with time for cells in barrier pillar of 1 North outby site during Panel 1 retreat at Mine A.

Figure A11. BPC pressures with time for cells in south pillar of 1 North outby site during Panel 1 retreat at Mine A

Figure A12. BPC pressures with time for cells in north pillar of 1 North outby site during

Panel 1 retreat at Mine A

Figure A13. BPC pressures with time for cells in south pillar of 2 North outby site during Panel 1 retreat at Mine A

Figure A14. BPC pressures with time for cells in north pillar of 2 North outby site during 
Figure A15. BPC pressures with time for cells in barrier pillar of 2 North outby site during Panel 1 retreat at Mine A.

Figure A16. BPC pressures with time for cells in south pillar of 2 North outby site during Panel 2 retreat at Mine A

Figure A17. BPC pressures with time for cells in north pillar of 2 North outby site during Panel 2 retreat at Mine A

Figure A18. BPC pressures with time for cells in barrier pillar of 2 North outby site during Panel 2 retreat at Mine A.

Figure B1. Load on support Cans with time for support Cans located in 2 North gate roads at intersection of entry 3 and crosscut 10 at Mine A

Figure B2. Load on support Cans with time for support Cans located in 2 North gate roads at mid-pillar in entry 3 between crosscuts 9 and 10 at Mine A. .106

Figure B3. Closure of support Cans with time for support Cans located in 2 North gate roads in entry 3 at crosscut 10 at Mine A

Figure B4. Closure of support Cans with time for support Cans located in 2 North gate roads in entry 3 at mid-pillar between crosscuts 9 and 10 at Mine A.

Figure B5. Manual roof-to-floor closure measurements taken near support Cans at Mine A

Figure C1. Entry closure with time of manually read stations at 1 North inby instrumentation site at Mine A.

Figure C2. Entry closure with time of manually read at 2 North inby instrumentation site at Mine A

Figure C3. Entry closure with time of manually read stations at 1 North outby instrumentation site at Mine A.

Figure C4. Entry closure with time of manually read stations at 2 North outby instrumentation site at Mine A.

Figure C5. Relative displacements between collar and anchors in roof over time at MPBX stations at 2 North inby instrumentation site at Mine A

Figure C6. Relative displacements between collar and roof anchors at string potentiometer extensometer set 1 at 1 North outby instrumentation site at Mine A

Figure C7. Relative displacements between collar and roof anchors at string potentiometer extensometer set 2 at 1 North outby instrumentation site at Mine A

Figure C8. Relative displacements between collar and roof anchors at string potentiometer extensometer set 3 at 1 North outby instrumentation site at Mine A

Figure C9. Relative displacements between collar and roof anchors at string potentiometer extensometer set 4 at 1 North outby instrumentation site at Mine A

Figure C10. Relative displacements between collar and roof anchors at string potentiometer extensometer set 5 at 1 North outby instrumentation site at Mine A 
Figure C11. Relative displacements between collar and roof anchors at string potentiometer extensometer set 1 at 2 North outby instrumentation site during Panel 1 retreat at Mine A

Figure C12. Relative displacements between collar and roof anchors at string potentiometer extensometer set 2 at 2 North outby instrumentation site during Panel 1 retreat at Mine A

Figure C13. Relative displacements between collar and roof anchors at string potentiometer extensometer set 3 at 2 North outby instrumentation site during Panel 1 retreat at Mine $\mathrm{A}$

Figure C14. Relative displacements between collar and roof anchors at string potentiometer extensometer set 4 at 2 North outby instrumentation site during Panel 1 retreat at Mine A

Figure C15. Relative displacements between collar and roof anchors at string potentiometer extensometer set 5 at 2 North outby instrumentation site during Panel 1 retreat at Mine A

Figure C16. Relative displacements between collar and roof anchors at string potentiometer extensometer set 1 at 2 North outby instrumentation site during Panel 2 retreat at Mine A

Figure C17. Relative displacements between collar and roof anchors at string potentiometer extensometer set 2 at 2 North outby instrumentation site during Panel 2 retreat at Mine A

Figure C18. Relative displacements between collar and roof anchors at string potentiometer extensometer set 3 at 2 North outby instrumentation site during Panel 2 retreat at Mine A

Figure C19. Relative displacements between collar and roof anchors at string potentiometer extensometer set 4 at 2 North outby instrumentation site during Panel 2 retreat at Mine A

Figure C20. Relative displacements between collar and roof anchors at string potentiometer extensometer set 5 at 2 North outby instrumentation site during Panel 2 retreat at Mine A

Figure C21. Nominal depths of anchors installed for sonic probe instruments used in this study at 1 North outby and 2 North outby instrumentation sites at Mine A

Figure C22. Displacements versus initial depth of anchor into borehole, relative to deepest anchor.

Figure C23. Displacements versus initial depth of anchor into borehole, relative to deepest anchor.

Figure C24. Displacements versus initial depth of anchor into borehole, relative to deepest anchor.

Figure C25. Displacements versus initial depth of anchor into borehole, relative to deepest anchor. 
Figure D1. Results of walking survey of average roof condition ratings by location in the 1 North gate roads at Mine A...

Figure D2. Results of walking survey of average rib condition ratings by location in the 1 North gate roads at Mine A.

Figure D3. Results of walking survey of average floor condition ratings by location in the 1 North gate roads at Mine A.

Figure D4. Results of walking survey of average roof condition ratings by location in entry 2 of the 2 North gate roads at Mine A

Figure D5. Results of walking survey of average rib condition ratings by location in entry 2 of the 2 North gate roads at Mine A

Figure D6. Results of walking survey of maximum rib condition ratings by location in entry 2 of the 2 North gate roads at Mine A

Figure D7. Results of walking survey of average floor condition ratings by location in entry 2 of the 2 North gate roads at Mine A

Figure D8. Results of walking survey of average roof condition ratings by location in entry 3 of the 2 North gate roads at Mine A ....

Figure D9. Results of walking survey of average rib condition ratings by location in entry

3 of the 2 North gate roads at Mine A

Figure D10. Results of walking survey of maximum rib condition ratings by location in entry 3 of the 2 North gate roads at Mine A .

Figure D11. Results of walking survey of average floor condition ratings by location in entry 3 of the 2 North gate roads at Mine A

Figure E1. Vertical section of idealized BPC target installation at Mine B

Figure E2. BPC pressure with time at T34 site at Mine B

Figure E3. BPC pressures with time at T33 site at Mine B 136

Figure E4. BPC pressures with time at T21 site at Mine B

Figure E5. BPC pressure with time at T20 site at Mine B

Figure E6. BPC pressure with time at $\mathrm{H} 43$ site at Mine B 138

Figure E7. BPC pressures with time at $\mathrm{H} 42$ site at Mine B. 138

Figure E8. BPC pressures with time at $\mathrm{H} 22$ site at Mine B

Figure E9. BPC pressure with time at $\mathrm{H} 21$ site at Mine B

Figure F1. Loads on support Cans at Mine B sites

Figure G1. Target closure measurements with string potentiometers, shown along centerline of entry, in phase 1 of the field study at Mine B 144

Figure G2. Closure with time as measured with string potentiometers at and near support Can at Phase 1 site of T6 in B-11 panel tailgate at Mine B.... 
Figure G3. Closure with time as measured with string potentiometers at and near support

Can at Phase 1 site of T5 in B-11 panel tailgate at Mine B

Figure G4. Closure with time as measured with string potentiometers at and near support Can at Phase 1 site of T16 in B-11 panel headgate at Mine B.

Figure G5. Closure with time as measured with string potentiometers at and near support Can at Phase 1 site of T15 in B-11 panel headgate at Mine B

Figure G6. Target closure measurements with string potentiometers, shown along centerline of entry, in phase 2 of the field study at Mine B.

Figure G7. Closure with time as measured with string potentiometers at and near support Can at T39 in B-12 panel tailgate at Mine B ....

Figure G8. Closure with time as measured with string potentiometers at and near support Can at T34 in B-12 panel tailgate at Mine B 148

Figure G9. Closure with time as measured with string potentiometers at and near support Can at T33 in B-12 panel tailgate at Mine B

Figure G10. Closure with time as measured with string potentiometers at and near support Can at T21 in B-12 panel tailgate at Mine B

Figure G11. Closure with time as measured with string potentiometers at and near support Can at T20 in B-12 panel tailgate at Mine B

Figure G12. Manually measured entry height (floor anchor to roof anchor) plotted with location, with symbols indicating time of measurement

Figure G13. String potentiometer closures versus manually measured entry closures at Mine B

Figure H1. Ground condition ratings plotted with location in the B-11 tailgate at Mine B

Figure H2. Ground condition ratings plotted with location in the B-11 headgate at Mine B......154

Figure H3. Displacement between collar and roof extensometer anchors at H42

at Mine B, plotted with time

Figure H4. Displacement between collar and rib extensometer anchors at H42

at Mine B, plotted with time 


\section{Tables}

Table 1. Summary of in situ stress measurements in area as reported by Agapito et al..............6

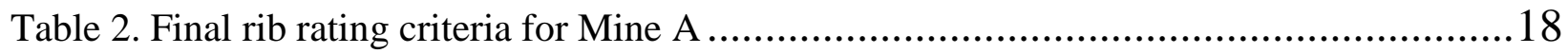

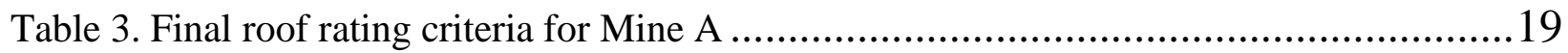

Table 4. Final floor rating criteria for Mine A …........................................................... 19

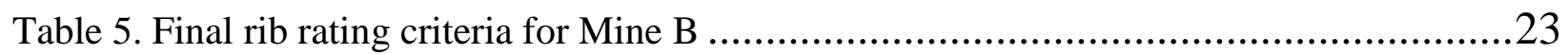

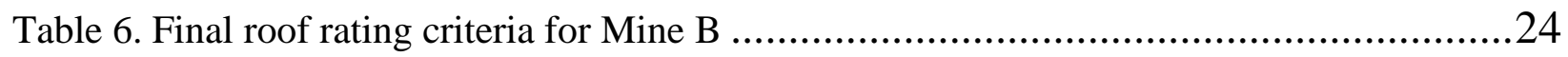

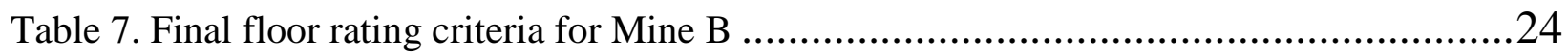

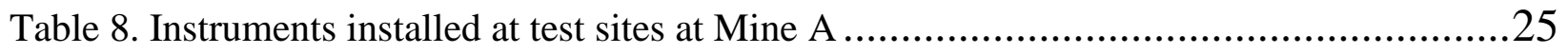

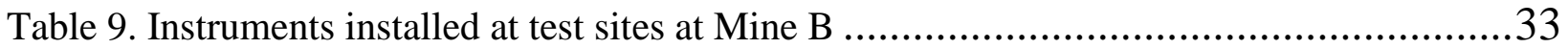

Table 10. Distances from face along gate road of first indication of arrival of abutment stress at BPCs at 1 north outby station and resulting distance to gob corner-method of

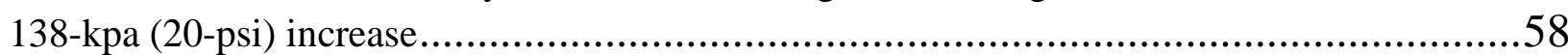

Table 11. Distance from face along gate road of first indication of arrival of abutment stress at BPCs at 2 north outby station and resulting distance to gob corner-method of

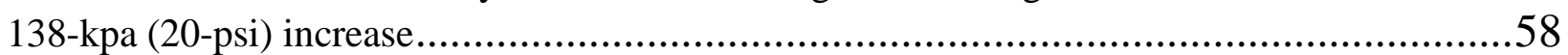

Table 12. Summary of distance to face at first arrival of mining-induced abutment stress as measured with BPCs at Mine B

Table 13. Distance from face along gate road of first indication of arrival of abutment load at instrumented support Cans at 2 north outby station at Mine A and resulting distance to gob corner - method of 0.267-kn (0.03-ton) increase

Table 14. Distance from face along gate road of first indication of arrival of abutment load at outby instrumented support Can at H21 station at Mine B and resulting distance to gob corner. This distance was determined by the method using the first sustained load

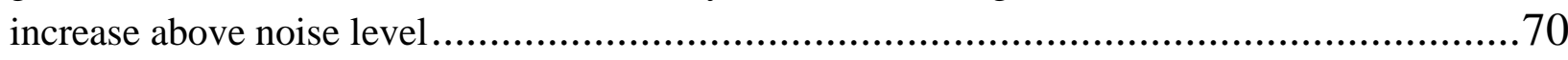

Table 15. Range indication when abutment load was sensed by observation with ground condition ratings at instrumented outby sites at Mine A .

Table 16. Distance from face along gate road of first indication of arrival of abutment stress at closure meters in entry 3 near the 2 north outby station and resulting distance to gob corner - method of -2.54-mm (-0.01-in) threshold departure from initial closure trend .......78

Table 17. Summary of distance to face and to gob corner when first arrival of mining-induced abutment stress was first detected, as determined with closure

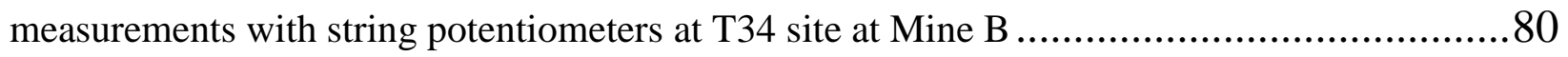

Table 18. Summary of distance to gob corner at Mine A by instrument and location...............83

Table 19. Summary of distance to gob corner at Mine B by instrument and location ...............84 


\section{ACRONYMS AND ABBREVIATIONS}

ALPS

BPC

CMRR

LTD

MPBX

NA

$\mathrm{NIOSH}$

pot.

Std. dev.
Analysis of Longwall Pillar Stability

borehole pressure cell

Coal Mine Roof Rating

load transfer distance

Multiple Position Borehole Extensometer

not available

National Institute for Occupational Safety and Health

potentiometer

standard deviation

\section{UNIT OF MEASURE ABBREVIATIONS}

$\begin{array}{ll}\mathrm{cm} & \text { centimeter or centimeters } \\ \mathrm{ft} & \text { foot or feet } \\ \mathrm{hr} & \text { hour or hours } \\ \mathrm{in} & \text { inch or inches } \\ \mathrm{kip} \text { or kips } & \text { kilopound or kilopounds } \\ \mathrm{kN} & \text { kilonewton or kilonewtons } \\ \mathrm{kPa} & \text { kilopascal or kilopascals } \\ \mathrm{lb} & \text { pound or pounds } \\ \mathrm{m} & \text { meter or meters } \\ \mathrm{mm} & \text { millimeter or millimeters } \\ \mathrm{MN} & \text { Meganewton or Meganewtons } \\ \mathrm{MPa} & \text { Megapascal or Megapascals } \\ \mathrm{N} & \text { Newton or newtons } \\ \mathrm{oz} & \text { ounce or ounces } \\ \mathrm{psi} & \text { pounds per square inch } \\ \text { ton } & \text { English ton or tons } \\ \text { tonnes } & \text { metric ton or tonnes }\end{array}$




\title{
Ground Stress in Mining (Part 1): Measurements and Observations at Two Western U.S. Longwall Mines
}

\author{
Mark K. Larson, ${ }^{1}$ Heather E. Lawson, ${ }^{2}$ Eric G. Zahl, ${ }^{3}$ and Tristan H. Jones ${ }^{4}$
}

\begin{abstract}
Researchers from the National Institute for Occupational Safety and Health (NIOSH) have been conducting research with the goal of gaining a better understanding of ground stress redistribution resulting from mining. The research involves representing stress redistribution using empirical equations or numerical models that are calibrated to observations and measurements. Numerical models are then used to calculate ground stress in mines.

NIOSH researchers compiled data sets from two coal mines in western Colorado, herein referred to as Mine A and Mine B. These data sets include observations and measurements as successive, adjacent panels of coal were retreated at each mine. The data sets specifically include general observations of ground behavior, observations from ground condition surveys, measurements of pressure change with borehole pressure cells (BPCs), measurements of load and closure of instrumented support Cans ${ }^{5}$, manual and datalogger-monitored measurements of roof-to-floor entry closures, manual and datalogger-monitored measurements of roof sag with extensometer, and manual measurements of roof sag using sonic probes. These data sets are described in detail in this report.

Methods were established to determine load transfer distance with various methods by detecting with borehole pressure cells, instrumented support Cans, closure measurements, and ground condition surveys the distance ahead of the face at which a mining-induced load is first sensed in the pillars and abutments. A knowledge of load transfer distance is important for calibrating numerical models for evaluating mine layout design to reduce risk of ground instabilities. Load transfer distance also forms a basis for empirical methods. Measuring first arrival of mining-induced abutment stress is necessary to determine load transfer distance.

In detecting first arrival of mining-induced stress, BPCs required the most installation effort, were most sensitive to abutment load, and yielded information about behavior of the pillars. Support Can loads, entry closures, and Can closures generally were not consistent enough to yield a reasonable degree of success in detecting first arrival of mining-induced abutment stress. Ground condition surveys were least sensitive to abutment stress but are the least costly option. Such surveys might be used alongside limited instrumentation to discern variations in the first arrival of abutment stress.
\end{abstract}

${ }^{1}$ Mining Engineer, Ground Control Branch, NIOSH Mining Program, Spokane, Washington. 2Physical Scientist, Ground Control Branch, NIOSH Mining Program, Spokane, Washington. ${ }^{3}$ Retired Civil Engineer, Ground Control Branch, NIOSH Mining Program, Spokane, Washington. ${ }^{4}$ Formerly Research Fellow, Ground Control Branch, NIOSH Mining Program, Pittsburgh, Pennsylvania.

${ }^{5} \mathrm{~A}$ secondary support consisting of a thin-walled, metal can, filled with cementitious material, and placed in the entry to minimize roof-to-floor closure. It was originally developed by Burrell Mining Products as "The CAN." In this report, the first letter is capitalized because other manufacturers have developed similar versions. 


\section{Introduction}

Designing and evaluating coal mine layout remains a tremendous challenge because of complex, variable geology and mining of deep seams. Appropriate coal strength and pillar strength formulas and methods [Gaddy 1956; Holland 1964; Obert and Duvall 1967; Bieniawski and Van Heerden 1975; Hustrulid 1976; Wilson and Ashwin 1972; Wilson 1981; Barron and Pen 1992; Bieniawski 1981; Mark and Chase 1997] are necessary and have been used in the design and analysis processes.

Understanding the redistribution of ground stress with mining progress is fundamental to determining a good mine layout design. Proper design of mines is necessary to ensure stable ground and to preserve a safe working environment for mine workers. Mark [1987] developed an empirical method, Analysis of Longwall Pillar Stability (ALPS), to calculate stability factors for longwall gate roads and built a database to determine a critical stability factor that statistically predicts the margin between successful and unsuccessful layouts. The method created a database of cases for which stability factors were determined for a given gate road, panel geometry, and overburden height. Mark et al. [1994] determined that a critical stability factor equation, which reasonably separates successful gate road designs from those that were not successful, is dependent upon the sites' Coal Mine Roof Rating (CMRR), described by Molinda and Mark [USBM 1994] as

$$
S F_{\text {crit }}=1.76-0.014(C M R R)
$$

where $\quad S F_{\text {crit }}=$ critical stability factor, and

$C M R R=$ Coal Mine Roof Rating.

Mark and Chase [1997] extended the empirical system to room-and-pillar retreat mining with another database and program, Analysis of Retreat Mining Pillar Stability (ARMPS), based on the same assumptions. Here, the critical stability factor was determined to be dependent upon height of the overburden.

Such empirical systems are valuable because they compare cases statistically to determine whether a design is likely to be suitable for a situation. Such assessment is quick and reduces the time required to perform the assessment. The authors of this report gratefully acknowledge the work that has produced these empirical databases and the value of the quick answers they provide. However, a caution is appropriate when conditions depart significantly from the basic assumptions of the method and the underlying cases, and caution is appropriate also when mechanisms are present that merit more detailed observation, measurement, study, and assessment. The duty of the researcher is to continually improve the method or use a method that more appropriately assesses significant mechanisms. Sometimes, using another assessment tool is necessary to assess specific risk.

One basic assumption for the empirical method is that load transfer distance is represented reasonably well by the equation of Peng and Chiang [1984] — that is,

$$
L T D=9.3 \sqrt{H}
$$

where $L T D=$ load transfer distance in $\mathrm{ft}$, and

$$
H \quad=\text { height of the overburden, also in } \mathrm{ft} .
$$

Although this equation was based on measurements with borehole pressure cells and stressmeters, the number of cases was small and all were located either in Appalachia or the Illinois Basin. 
Another assumption is the overpanel load distribution. With reference to Figure 1, Mark [1987] determined that a value of the angle $\beta$ of $21^{\circ}$ would be sufficiently conservative to represent the amount of load transferred to the abutment. Lastly, for distribution of the load on the abutment, [Mark 1987] used the following equation, representing the stress added to the abutment from the edge of the gob to the load transfer distance:

$$
\sigma_{a}=\frac{3 L}{L T D^{3}}(L T D-x)^{2}
$$

where $\sigma_{a}=$ mining-induced stress on abutment,

$L=$ amount of overpanel weight transferred to the abutment $\left(L_{S}\right.$ or $\left.L_{S S}\right)$,

$L T D=$ load transfer distance, and

$x=$ distance from mined panel.
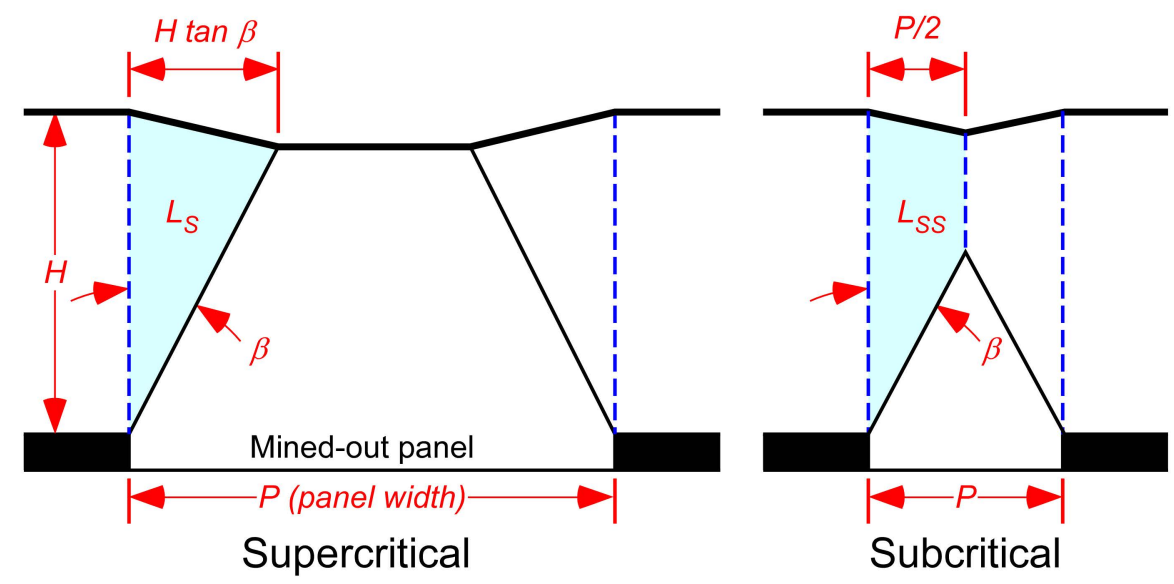

Figure 1. Distribution of overpanel weight for supercritical and subcritical panels. The weight of the shaded region is transferred to the adjacent abutment. Figure after ideas of King and Whittaker [1970].

While it is important to compare stability factors on the same basis, it is appropriate to acknowledge that significant departure of a case's conditions from the majority of underlying conditions in the database may cause one to question relevance of the calculated stability factor. For example, Lawson et al. [2013] found tailgate load concentration factors to be significantly sensitive to the site-specific $\beta$ and LTD, but such is not taken into account in the empirical method. Such sensitivity might be significant, for example in the case of the Deer Creek Mine, near Huntington, Utah, where the LTD had surpassed the distance to the next gate roads $229 \mathrm{~m}$ $(750 \mathrm{ft})$ away from the panel being mined [Goodrich et al. 1999].

Numerical methods have been used and have increasingly played a role in the analysis of mine layout stability. Displacement discontinuity methods such as Mulsim [USBM 1992a, 1992b] and LaModel [Heasley 1998, 2010] and the finite difference codes, FLAC [Itasca Consulting Group 2011] and FLAC ${ }^{3 D}$ [Itasca Consulting Group 2013], calculate different stress distributions and have specific limitations in following failure mechanics. Indeed, Larson and Whyatt [2009] found that choice of tool affected the solution space for stress distribution.

One important item for all of these tools is load transfer distance (LTD). It is used to calibrate stiffness of the rock mass or members of the rock mass. Although knowledge of the stressincrease profile is more desirable closer to the panel, such information is difficult to measure. Measurement of LTD is relatively easy. It is, therefore, very important to know the LTD in any 
mining case. It is not reasonable to expect that an equation can be fitted to nine measurements from a subset of cases that is not representative of all coal mining regions and expect that the whole population of sites conform to that equation. The measurements of LTD summarized by Abel [1988], including 55 measurements from 17 sources, does not contradict the empirical equation (Equation 2). However, Larson et al. [2015] found that instruments used can have different sensitivities, and the locations of the instruments with respect to the mining panel were ahead of the face in all of the data reported by Abel [1988], and not to the side of the panel, as LTD was defined by Peng and Chiang [1984]. In fact, Larson et al. [2015] concluded from this and other LTD data available that geology of the overburden has a significant effect on LTD. Clearly, the number of measurements of LTD needs to increase, and the methods of measurement standardized.

It may be possible to estimate LTD using any one of various methods. One such method might be to take advantage of beaming formula using an approach explained by Lucas et al. [1973, pp. 13-23]. However, that method is very site-specific to geology and material properties, particularly in relation to the stratigraphic members in proximity with the seam being mined. Another method might be to employ pressure arch theory. However, the underlying cases for the empirical equations are based on cases in the United Kingdom having different geology, and this theory would predict LTD to be less than that calculated by the Peng and Chiang equation. If estimation of LTD is the only means available, then using equations appropriate to overburden geology (i.e., whether the overburden has a semi-massive or massive member or not) as shown by Larson et al. [2015] may be an alternative.

Longwall acceleration position, the point where gate road closure rate is $10 \mathrm{~mm}$ per week, has been used in Australia in assessing support design and support density [Thomas and Wagner 2006] in longwall gate roads. While the longwall acceleration point might be linked to loading profile in some way, which would be very useful to calibration of models, that link has not yet been established.

MSHA [2009] issued guidance for using numerical models to evaluate mine stability where calibration of models is based on observations - presumably of ground conditions. This method is an alternative to using empirical methods to justify mine layout design. However, this guidance does not address using measurements of various types, for calibration of numerical models.

Data sets of measurements and observations can be used to measure LTD and to gain insight into stress redistribution that results from mining. Obtaining measurements and other possible members of such data sets vary in their cost in time, effort, and expenditures, and their usefulness likely varies.

This report is written in two parts, with Part 2 herein referred to as Ground Stress in Mining Part 2 and cited as NIOSH 2020. The purpose of this two-part report is to present measurements and observations that were obtained at two mines in western Colorado, to demonstrate how to determine LTD with that data, to gain insights of the ground behavior from that data, and to determine best paths forward in calibrating numerical tools to measurements and observations. The amount of information was extensive enough to require a division into two parts. In this report (Part 1), analyses are presented to evaluate the effectiveness and benefits of the various kinds of measurements that were conducted in this study and what they indicate about stress redistribution. This report focuses on the measurements made and the determination from these measurements of the first detection of the arrival of mining-induced abutment stress. In Ground Stress in Mining Part 2 [NIOSH 2020], these first arrivals are converted to load transfer distance 
at the side of the longwall panel, and various models are evaluated with respect to the measurements.

The results of this study will improve coal mine stability design by establishing recommended standards for measuring load transfer distance, using LTD to calibrate numerical models that provide improved predictions of pillar stability and pillar behavior, and revealing how to infer pillar material strength models from a measurements data set. Finally, gaps that still exist in evaluating pillar stability and predicting risk of ground control problems, including mining-induced microseismic events, will be described.

\section{Field Site Description}

Mines A and B are both located within the Piceance Creek depositional basin in the southern part of Colorado near the towns of Paonia and Somerset. The area is located within the North Fork Valley and is subject to dramatic topographic relief characterized by mountainous terrain and stream dissection. Minable seams are located within Paonia and Bowie Shale members of the Mesa Verde formation. Historically, coal seams A through F have been mined [Eakins et al. 1998], but current economically minable seams are limited primarily to the B Seam and the D Seam. Part of this column is represented in Figure 2.

Agapito et al. [2005] described that in earlier geologic times, various transgressions and regressions of the seashore over time in the area of these mines caused various depositional gradings of sandstone, shale, mudstone, and coal. Resulting from this depositional history, stratigraphic members often do not extend far laterally, but instead, pinch out. Predominant cleats in the coal seams are oriented from $\mathrm{N}^{\circ} 8^{\circ} \mathrm{E}$ to $\mathrm{N}^{\circ} 5^{\circ} \mathrm{E}$ [Carroll 2003]. Phillipson [2005] described bedding-plane and extensive thrust faulting in the Piceance Basin, which was interpreted to be related to tectonic compression associated with the Laramide orogeny. He mentioned predominant regional faulting having strike of $\mathrm{N} 70^{\circ} \mathrm{E}$. Harris et al. [2002] described various characteristics of faults above an igneous cupola at the West Elk Mine. Igneous intrusions occur in various places in the region; in this case, through the Mancos Shale, but near the West Elk Mine, an intrusion forms a cupola below the Rollins Sandstone, and affects fault formation above it. Carroll [2003] stated that primary joints in the near-seam sandstones in the area average $\mathrm{N} 76^{\circ} \mathrm{E}$ with $82^{\circ} \mathrm{SE}$ dip. In addition, he referred to secondary joints averaging $\mathrm{N} 18^{\circ} \mathrm{W}$ with $84^{\circ} \mathrm{SW}$ dip. Other processes perturbed the deposition. For example, faults perturbed the stress field during cleat formation [Robeck 2005].

Horizontal in situ stress measurements in the area of both mines were reported by Agapito et al. [2005]. Table 1 lists those measurements and includes gravitational horizontal stress calculated with an assumed Poisson's ratio of 0.28. Because of such high topographic relief in the area and a valley running slightly north of east, the minor principal stress might have been lowered by release of confinement from the presence of the valley. The major horizontal stress was an average of 2.9 times the gravitational stress, such that tectonic stress approximately parallel to the valley was not insignificant. The minor horizontal stress was an average of 0.99 times the gravitational stress.

In situations of high relief, horizontal stresses can concentrate below valleys and stresses measured below valley floors may be more indicative of regional tectonic stresses. Stresses measured to the side of valleys but above their floor elevation may experience relief from tectonic stresses, particularly in the direction perpendicular to the long axis of the valley. 
Therefore, measurements of stress at about the expected level of horizontal stress resulting from the weight of overburden and the Poisson effect is not surprising. A more accurate description of measurement location with respect to topography and status of completed excavations at the time of stress measurement would be required to develop an accurate regional stress model.

Coal Mine Roof Rating (CMRR) was not provided at either mine.

Table 1. Summary of in situ stress measurements in area as reported by Agapito et al. [2005]

\begin{tabular}{|c|c|c|c|c|c|c|c|c|c|c|c|}
\hline $\begin{array}{l}\text { Cover } \\
\text { depth, } \\
\text { m }\end{array}$ & $\begin{array}{l}\text { Cover } \\
\text { depth, } \\
\mathrm{ft}\end{array}$ & $\begin{array}{l}\text { Coal } \\
\text { seam }\end{array}$ & $\mathrm{P}, \mathrm{MPa}$ & $\mathbf{P}, \mathrm{psi}$ & $\mathrm{Q}, \mathrm{MPa}$ & $Q, p s i$ & $\begin{array}{c}\text { Azimuth } \\
\text { of } P\end{array}$ & $\begin{array}{c}P / Q \\
\text { ratio }\end{array}$ & $\begin{array}{l}\sigma_{h g}, \\
\mathrm{MPa}\end{array}$ & $\begin{array}{l}\sigma_{h g} \\
\text { psi }\end{array}$ & $\begin{array}{l}\mathrm{P} / \sigma_{h g} \\
\text { ratio }\end{array}$ \\
\hline 107 & 350 & B & 8 & 1165 & 1.9 & 273 & 69 & 4.2 & 1.05 & 153 & NC \\
\hline 496 & 1625 & B & 12.2 & 1768 & 4.2 & 612 & 97 & 2.9 & 4.90 & 710 & 2.49 \\
\hline 381 & 1250 & B & 9.8 & 1419 & 2.3 & 333 & 69 & 4.3 & 3.77 & 546 & 2.60 \\
\hline 274 & 900 & C & 4.5 & 655 & 1.9 & 275 & 98 & 2.4 & 2.71 & 393 & 1.67 \\
\hline 305 & 1000 & D & 9.2 & 1335 & 1.7 & 245 & 85 & 5.4 & 3.01 & 437 & 3.05 \\
\hline 320 & 1050 & B & 11.9 & 1725 & 5.8 & 840 & 67 & 2.1 & 3.16 & 459 & 3.76 \\
\hline 640 & 2100 & $B$ & 24.2 & 3510 & 5.5 & 800 & 78 & 4.4 & 6.33 & 918 & 3.82 \\
\hline \multicolumn{12}{|c|}{ Average: } \\
\hline
\end{tabular}

$\mathrm{P}=$ Major horizontal secondary principal stress

$\mathrm{Q}=$ Minor horizontal secondary principal stress

$\sigma_{h g}=$ Horizontal stress resulting from gravity, assuming Poisson's ratio $=0.28$

$\mathrm{NC}=$ Not calculated

Bumps and bursts occur in the region. Although solving such problems is beyond the scope of this report and its companion report, it is useful to describe what is known of bursts and bumps in the area of the field studies of this report.

Turnipseed and Reeves Jr [1976] described the occurrence of bumps and sudden floor heave at Mid-Continent Resource's Dutch Creek \#1 Mine. Hooker et al. [1974] reported that bounce areas tend to release rock noise well in advance of failure and that the rock noise rate changes dramatically preceding failure. They surmised that, with experience, it might be possible to determine where and when bounces would occur. Leighton and Steblay [1976] confirmed that rock noise rate at a deep western Colorado mine can be used to estimate when and where a failure would take place.

Fiscor [1994] reported no problems with rib bursting or bouncing when mining a thick seam at the West Elk Mine, in Colorado. However, Mark [2009] reported bumps in several room-andpillar mines in the U.S., including in the North Fork Valley of Colorado. Sears and Heasley [2009] acknowledged first-time bump events at the Bowie and Elk Creek Mines in the Piceance Basin. Harvey et al. [2009] described a rib support system designed to absorb some of the kinetic energy released from violent ejection of coal from ribs.

Mark et al. [2012] reported that many bumps have occurred in the area using different mining methods. They described the roof as often being shale instead of sandstone, and bump occurrences typically located some distance from high stress areas. They also concluded from mapping that bumps were often associated with low-angle faults and areas of well-defined highdensity jointing having little associated displacement. They described cleats as being present throughout the area of this study with a predominant orientation of $\mathrm{N} 70^{\circ} \mathrm{E}$. 
Because the ultimate goal of this report and its companion report together is to develop or recommend guidelines toward numerical model calibration that more accurately reflect loading, solving and mitigating bursting and bump problems is beyond the scope of these reports. However, reducing the risk of bumps is an important goal at both mines where this study was done. Calibrating and verifying loading is a necessary step before seismic events can be well understood in this region.

\section{Mine A}

Observation and measurements at Mine A were limited to two sets of gate roads on either side of a single panel. Ground control concerns had driven a significant change in pillar design between the two gate roads, offering a unique opportunity to observe ground behavior characteristics in two gate roads of different designs (see Figure 3) but with similar geologic conditions and in close geographic proximity to each other.

At the time of this study, Mine A was excavating the upper split of the D Seam (DU Seam), with an estimated average thickness from 3.4 to $4.3 \mathrm{~m}$ (11 to $14 \mathrm{ft}$ ). Entry height was cut to 3.0 to $3.4 \mathrm{~m}$ (10 to $11 \mathrm{ft}$ ), with coal left in the floor. The D Seam is vertically continuous in some areas and may exceed $6.2 \mathrm{~m}(20 \mathrm{ft})$ in thickness. Multiple seam mining, although present in other areas of the underground workings, was not a factor in or near the study area. 


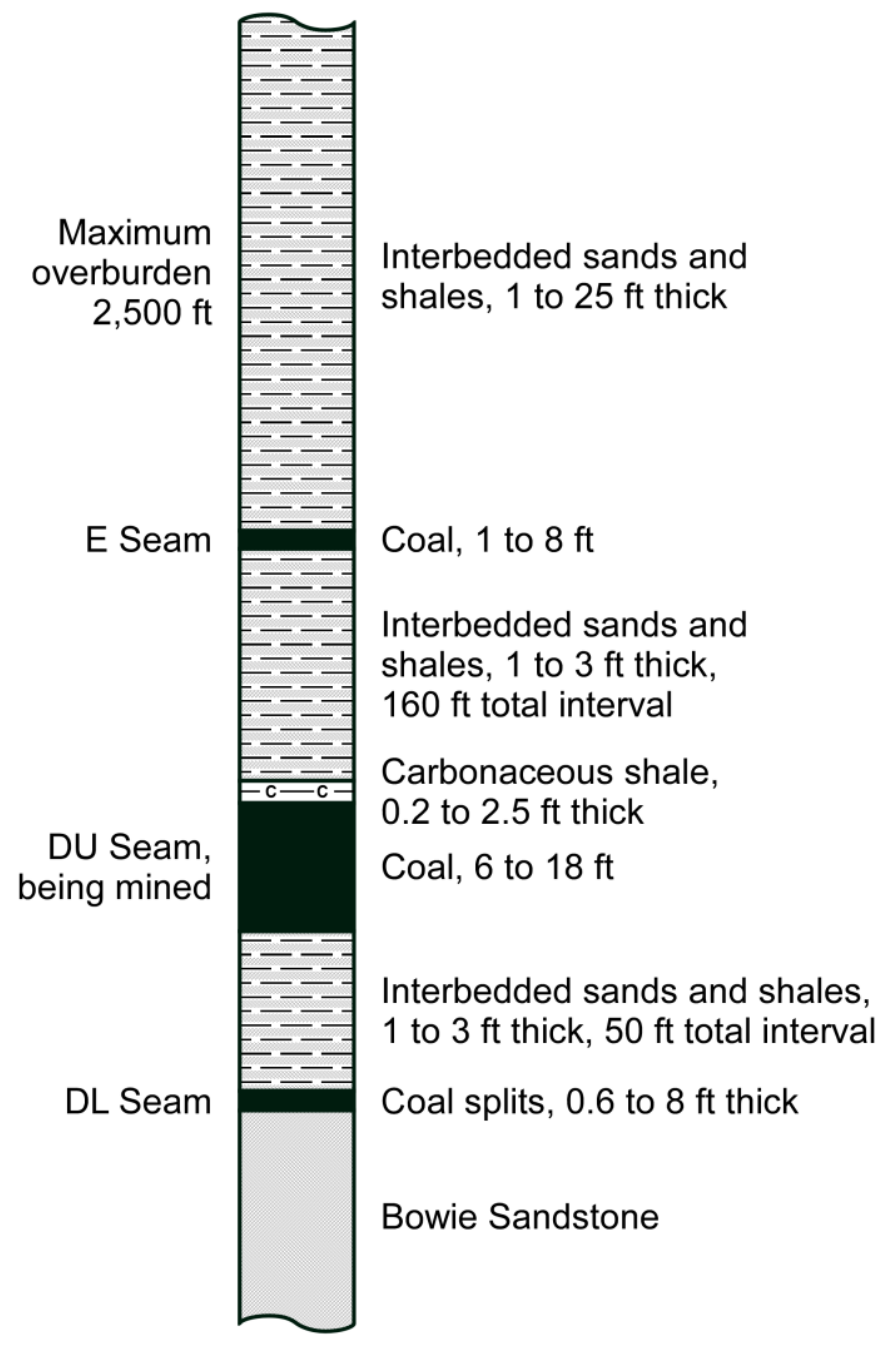

Figure 2. Generalized stratigraphic column provided by Mine A.

Frequent transgressive-regressive episodes have resulted in a stratigraphic column characterized by rapid lithologic shifts. Typical rock types include sandstones, siltstones, mudstones, carbonaceous mudstones, bone coal, and coal. Beds in close proximity to the coal seam are generally relatively thin, less than $6.1 \mathrm{~m}(20 \mathrm{ft})$ thick, and more frequently on the scale

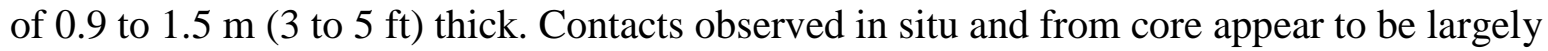
gradational, and lithologic variations occur rapidly over relatively short lateral distances. 


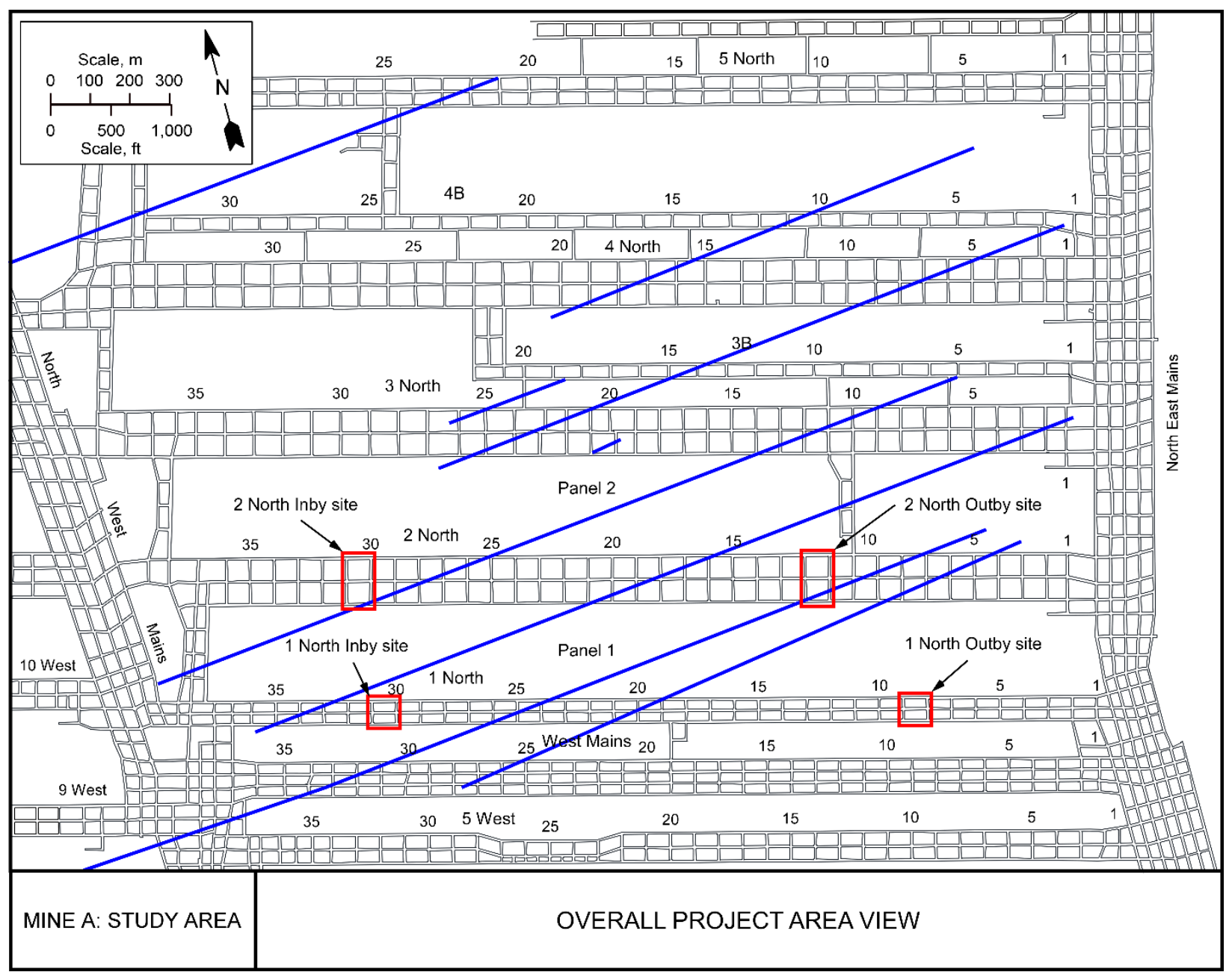

Figure 3. Mine map of Mine A with overlain mapped and projected faulting. Blue lines indicate both mapped and projected faults. Red boxes indicate location of main instrument sites in this study.

Roof lithology overlying 1 North gate roads and 2 North gate roads is extremely variable. In general, the immediate roof is characterized by some depth of mudstone followed by a silty to sandy interval. The mudstone extends into the roof for a variable distance and may or may not

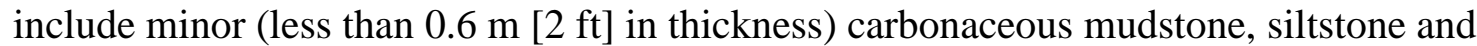
sandstone beds, and coal stringers. Four cored roof holes and analysis of the 15 and 16 series gob vent boreholes indicate that the interval of mudstone-dominated roof rock ranges from 2.4 to 9.8 $\mathrm{m}(8$ to $32 \mathrm{ft})$ at the drilled locations. This mudstone-dominated interval does not represent a massive mudstone, but rather an interbedded unit in which mudstone is the dominant lithology.

The overall character of the roof in 1 North gate roads is muddier in nature than the roof in 2 North gate roads. The mudstone appears to thin in a westward direction, ranging from approximately 9.8 to $5.8 \mathrm{~m}$ (32 to $19 \mathrm{ft}$ ) in thickness.

The 2 North gate roads, by contrast, are overlain by a depth of mudstone which appears to be variable, and differences in thickness appear to be localized rather than to follow an overall thinning or thickening trend. The mudstone appears to vary from 2.4 to $5.2 \mathrm{~m}$ ( 8 to $17 \mathrm{ft}$ ) in thickness and to be overlain by a silty to sandy unit which may be associated with a channel deposit. A scour contact encountered between crosscuts 30 and 31 in entry 2 followed by an 
approximately $1.1-\mathrm{m}(3.5-\mathrm{ft})$ thick sandstone grading upwards to a muddy siltstone further suggests that the western region of 2 North gate roads is subject to the influence of an overlying sandstone channel or channels. Similar features may account for some of the localized variations in roof lithology across 2 North gate roads.

In September of 2009 a series of holes were drilled by NIOSH personnel into the floor using a handheld drill in the 1 and 2 North gate roads to determine the depth of floor coal. Chip analysis consistently indicates a depth of floor coal ranging from approximately 0.6 to $1.5 \mathrm{~m}$ (2 to $5 \mathrm{ft}$ ), underlain by a hard mudstone unit for an unknown distance. Analysis of gob vent borehole geophysical logs indicates that a split between the upper and lower D Seam (referred to as DU Seam and DL Seam in this report) may be encountered in 1 North gate roads. Information regarding floor lithology is fairly limited. However, based upon the available information, it appears that the seam may begin to split near crosscut 11 in 1 North gate roads. Interburden thickness appears to increase to the north and west. The split is firmly established and begins to thicken rapidly towards 2 North gate roads. Insufficient data was available to identify the thickness of the split, but it was in excess of $4.6 \mathrm{~m}(15 \mathrm{ft})$ in some locations.

Structurally, the mine area is characterized by several parallel, steeply dipping, roughly eastwest trending regional faults [Agapito et al. 2005]. These faults appear to have no surface expression. Normal offset is generally $3.0 \mathrm{~m}(10 \mathrm{ft})$ or less. Smaller, localized normal faulting was also observed and may have been the result of differential compaction around depositional features, such as kettlebottoms. These smaller faults were observed to have minimal impact on entry deterioration.

The regional faulting, oriented at approximately N80E, was extremely difficult to locate in the mine shortly following development. During the development phase, on clean working faces, faulting was obvious and easy to identify. Our personnel were not present during the entire development of the gate roads and were left to identify faulting after identification became more problematic. Vertical offsets were generally small, less than $3.0 \mathrm{~m}(10 \mathrm{ft})$, and clear marker beds or partings were not available for correlation. Sloughing began almost immediately after the ribs were cut. These factors, in combination with rock dusting, serve to obscure the visibility of fault planes in the roof and ribs almost immediately after development. Regional faulting was most easily identified by areas of unusually deteriorated conditions in conjunction with structure mapping conducted by the mine during development. The deterioration often took the form of significantly more deteriorated rib and floor conditions, and some level of roof deterioration. Roof deterioration was relatively uncommon in the 2 North gate roads and served as an indicator that faulting may be present.

Figure 3 shows a plan view of the study area in Mine A. Prominent faults that were dipping $80^{\circ}$ to $85^{\circ}$ are indicated. Pillars instrumented with BPCs are outlined in red. The depth of the seam near the two eastern instrumented sites averaged about $686.9 \mathrm{~m}(2,253.5 \mathrm{ft})$.

\section{Mine B}

Mine B operates within the same depositional basin as Mine A, within close geographic proximity. As such, the geologic setting described earlier in this document also pertains to Mine B. Differences between the two sites result primarily from differences in mining practice and design, and geologic variability on a local scale.

Figure 4 shows a stratigraphic column constructed from core taken in the B-12 gate road at crosscut 23. The mine, at the time of observation, operated within the upper B Seam, below the 
D Seam. Mining had taken place in both the D Seam and the B Seam at various points in the mine's history, but multiple seam mining interactions were not a factor in the gate roads slated for investigation. Figure 5 shows the instrumentation site locations in relation to the panel layout. The immediate roof and floor at these locations are composed of coal. A mudstone unit overlies the coal left in the roof during development. Seam depth at the Phase 2 sites averages $295 \mathrm{~m}$ (969 ft) but is approximately $335 \mathrm{~m}(1,100) \mathrm{ft}$ at the $\mathrm{H} 22$ site. This last depth was important for modeling by Larson et al. [NIOSH 2020] in Ground Stress in Mining Part 2 because it was more representative of the depth of the next panel. 


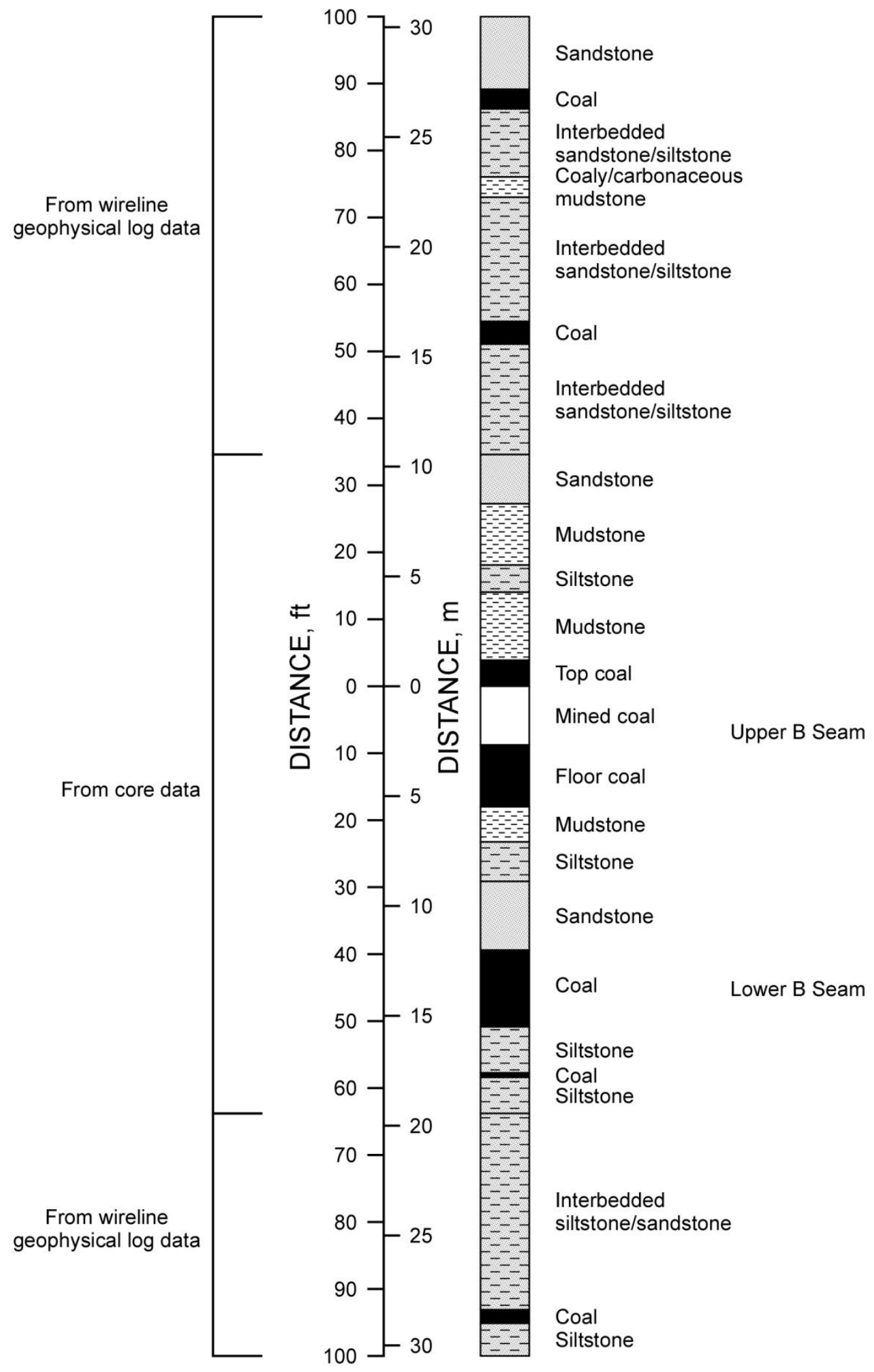

Figure 4. A stratigraphic column constructed from core taken in the B-12 headgate at crosscut 23 in Mine B. 


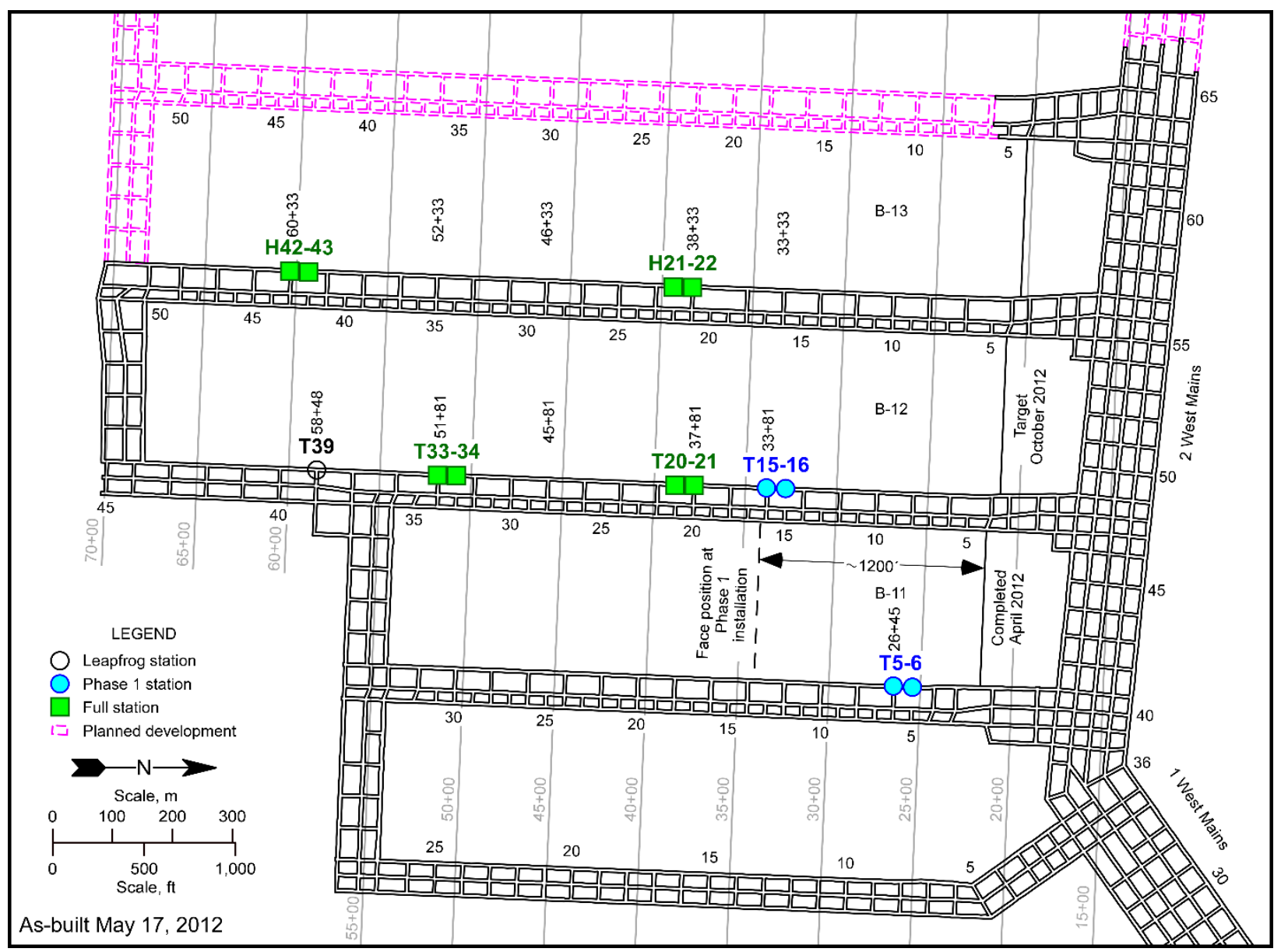

Figure 5. The locations of instrument sites in the B-11 and B-12 panel gate roads at Mine B.

Although Mine A and Mine B shared the same geologic setting, the following distinctions between the two with respect to design and lithology were identified as potentially contributing to the manner in which deterioration would manifest:

- The B Seam is more brittle and more heavily faulted than the overlying D Seam.

Additionally, faulting may have a more visually far-reaching effect than faulting in the D

Seam; cleat orientation within the B Seam has been documented to realign with fault orientation for a distance of up to $500 \mathrm{~m}(1,640 \mathrm{ft})$ away from the discontinuity plane [Robeck 2005]. This phenomenon was not observed by NIOSH researchers in the D Seam in Mine A.

- Mine B has adopted the practice of leaving $0.46 \mathrm{~m}$ (18 in) of head coal to prevent the soft overlying mudstone from failing. This means that the roof/rib interface is unlikely to separate. This was a key beginning stage stress indicator at Mine A, where the ribs and roof were delineated by a bedding plane between two different rock types.

- The overall roof lithology at Mine B appeared to be significantly muddier than that at Mine A.

- Mine B gate roads are oriented in such a way that the entries are parallel to the butt cleat, and crosscuts are parallel to the face cleat. At Mine A, cleat orientation was oblique to both crosscuts and entries. This difference in relative interception of cleat in the rib impacted the degree and nature of skin failures on the pillars. 


\section{Observations}

Mine A

\section{Observations of Ground Behavior}

Observations of ground behavior were made in three ways. Relative observations were made by the crew who drilled boreholes for BPCs. Observations of caving were made by one of the authors. Finally, more detailed observations of ground deterioration were made via ground conditions surveys of the floor, ribs, and roof. The following sections describe those observations. For the ground condition surveys, the method is first described, and the results follow.

\section{Observations of Drilling}

Agapito and Associates, Inc. (AAI) was contracted by Mine A to design the instrumentation plan, to drill the boreholes for the BPCs, to install the BPCs, to drill and install Multiple Position Borehole Extensometers (MPBXs) in the roof at one site, and to take core from the floor and roof. Mine personnel drilled holes for other sag meters - string potentiometers and sonic probes. NIOSH participated by providing and supporting dataloggers to read the BPCs and sag meters. In the process of drilling boreholes and installing the BPCs, AAI crew members commented to more than one of the authors of this study about their relative experience of drilling in this area. The consensus was that, in all locations where they drilled as part of this study, the DU Seam was softer and weaker than the B Seam, which they had drilled in earlier studies. They based this judgment mostly on how fast the borehole would close or deform, thus making cell installation very difficult and sometimes impossible so that sometimes a hole had to be abandoned. Differences in overburden stress did not account for the difference in borehole behavior.

The conclusions of the drilling crew may not have been accurate. Borehole closure may occur because of inelastic behavior of the coal. Although the observation of more borehole closure in the DU Seam with respect to the B Seam is important, especially in terms of instrument installation, the cause may not necessarily be attributed to a less stiff or weaker DU Seam.

\section{Observations of Caving}

One of the authors observed during mining of the first half of Panel 1 that caving was gradual, but it took place immediately behind the face. Caved material could be observed looking inby from the \#3 entry of the tailgate. However, when the face was near the outby instrument site in the tailgate of Panel 1, the roof was observed to have markedly different behavior-it did not cave. On April 20, 2010, and again the next day, the roof was observed by the same author to sag down until it met the floor, with increased sagging with distance away from the face and the tailgate pillars. Shining a cap lamp down the \#3 entry inby, one could see approximately $90 \mathrm{~m}$ (300 ft) and detect that the same sagging phenomenon was consistent, but roof sag increased with distance behind the face. Although the roof behind the face was intact, there was small, localized rubble observed that had fallen from the roof, but otherwise, the roof remained relatively smooth, but sagged as described instead of caving. The location along the tailgate where no caving began was never observed by the authors. 
Localized failure of the roof was observed on April 20-21, 2010, but no more than about 23 $\mathrm{m}$ (75 ft) outby the face in entry \#3 and inby from there. Entry \#2 had a zipper-like failure in the mesh at the entry centerline that extended about $30 \mathrm{~m}(100 \mathrm{ft})$ and dumped a significant amount of rubble on the floor- $1.8 \mathrm{~m}(6 \mathrm{ft})$ wide at the base, having a height of 0.3 to $0.6 \mathrm{~m}$ ( 1 to $2 \mathrm{ft}$ ). On April 21, entry \#1 became closed at crosscut 9. Also, several support Cans in entry \#3 outby the face exhibited knee (buckling) failure.

During this time, the panel was excavated such that the floor was about $1.2 \mathrm{~m}(4 \mathrm{ft})$ below the elevation of the tailgate floor. The roof was observed, again from the \#3 entry of the tailgate looking inby, to stay intact and sag. Eventually, the roof sagged enough to make contact with the panel floor at some distance behind the face and away from the tailgate.

\section{Geophysical Logs}

Given the caving observations, indicating at least a change in roof structure, geophysical logs were examined to determine significant lithologic differences at various boreholes over Panel 2, but near 2 North gate roads. Because the range of density logs was limited, interpretation could be accurate only for a small horizon surrounding the DU Seam. Figure 6 is a fence diagram showing the lithology at each of those boreholes, with borehole location shown on a map. In the horizon of these logs, no significant sandstone channel exists that would suggest a reason for the difference in caving. 


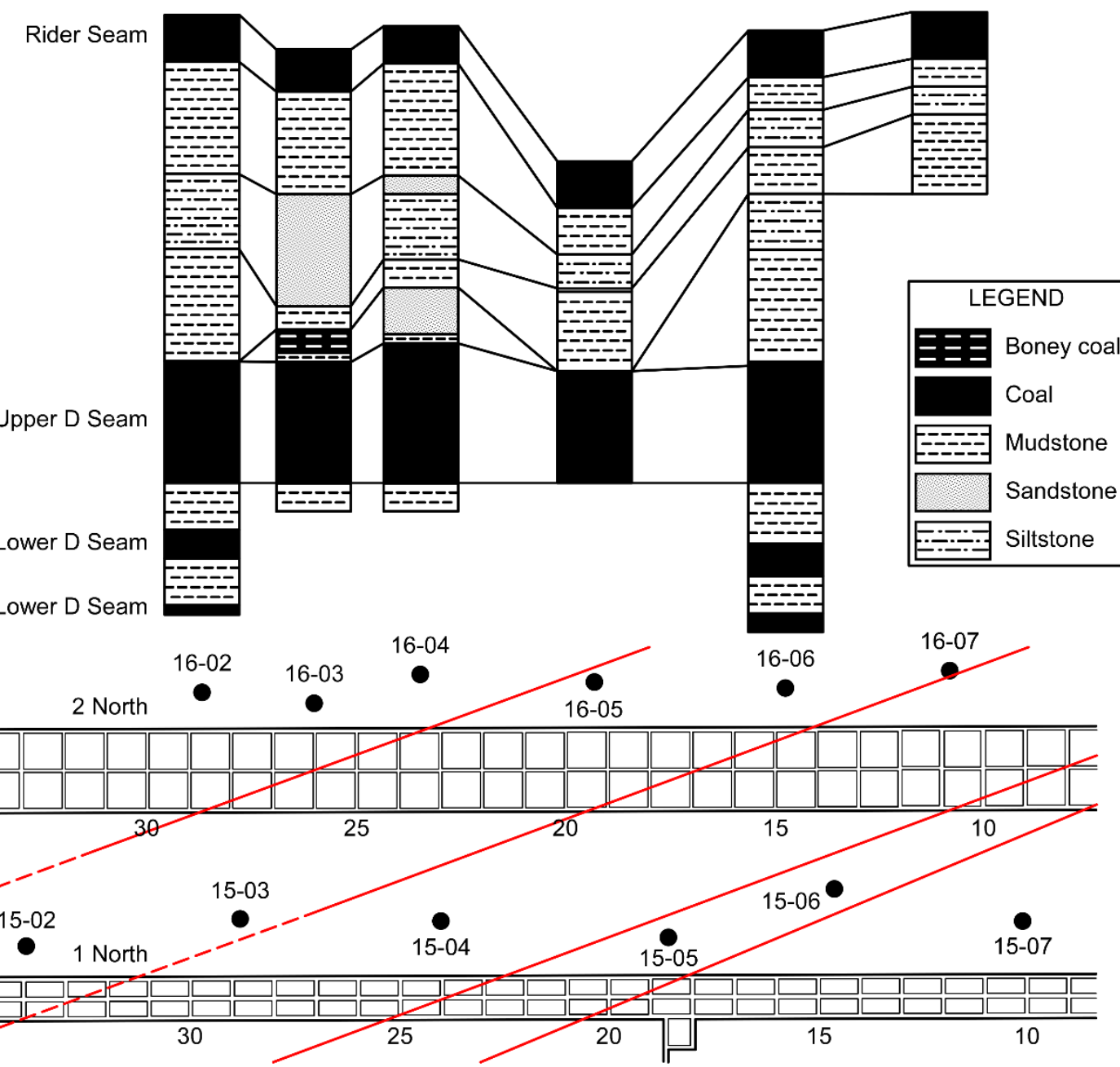

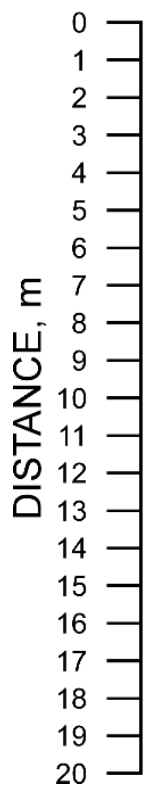

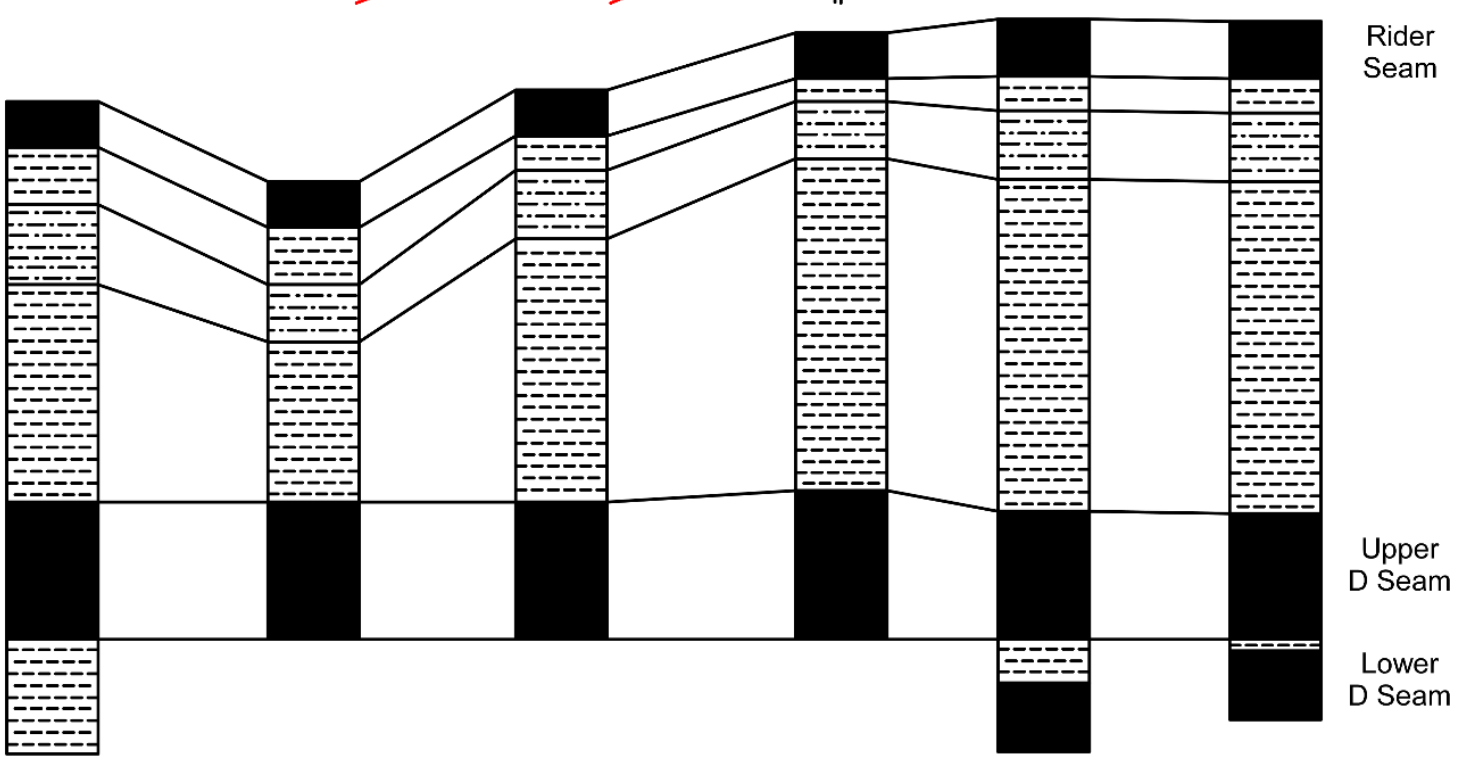

Figure 6. Fence diagrams of near-seam stratigraphic structure at Mine A, determined from geophysical logs of gob vent boreholes. 


\section{Ground Condition Surveys}

The intention of deterioration surveying was to rate the visible changes indicative of geotechnical instability over time in the roof, ribs, and floor independently of one another and to allow meaningful interpretation of instrument measurements. This rating system was developed at Mine A in response to local observations [Lawson et al. 2012]. Taking into account that early warning signs of instability may vary from mine to mine, dependent upon local changes in geologic setting, design/support practices, or mining orientation, the individual criteria used to rate deterioration at Mine A were specifically tailored to this mine based upon observation over time and input from mine personnel.

In setting out to design a rating system for this particular study site, a number of other factors were deemed essential to success. These include:

- Ratings must be clear and consistent - in both development and later interpretation. That is, subjective interpretation by both raters and users should be minimized so that there is a clear and consistent understanding of the conditions at a rated location. The addition of quantitative standards, wherever possible, should be undertaken.

- Ratings need to be relatively simple, so as to be easily learned and applied by both raters and users. To this end, it is useful to "tune" rating criteria to the failure modes that are both active at and important to the study site.

- The rating scheme should be flexible. It needs to be reviewed periodically to evaluate whether modifications are needed to incorporate new modes of deterioration. This is a particular concern where local geologic conditions may drive significantly different or more intense deterioration. Conditions outside the expected range should be carefully noted.

- Finally, the safety, time expenditure, and training of those conducting the surveys should be taken into consideration.

It was also necessary to account for differing backgrounds of individual observers. Ideally, the system can be implemented by geologists, engineers, and production staff with varying amounts of experience. By describing, in detail, conditions of concern, the influence of a specific observer's background is reduced. Where rating participants fell short of this ideal, occasional cooperative mapping was used to synchronize ratings.

The frequency of deterioration surveys would ideally be based on the rate of face advance. In this instance, limited travel opportunities restricted survey frequency to about once every 4-6 weeks, although greater frequency would have been preferable.

Entry surveys were conducted by observers walking the entry length, taking care to observe conditions in the ribs, roof, and floor. An average rating was recorded for an interval spanning between crosscuts. For instance, beginning at crosscut 1, an observer may walk down entry 2, ending the first interval at crosscut 2. Suppose that the ribs on average appear to have shed

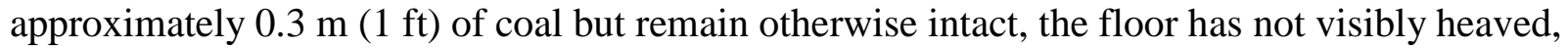
and the roof does not sag, but joint apertures are open by $1.3 \mathrm{~cm}(1 / 2 \mathrm{in})$ and a large slick runs subparallel to the entry for a distance of $15 \mathrm{~m}(50 \mathrm{ft})$. These conditions would result in a rib rating of 1 , a floor rating of 0 , and a roof rating of 1 . Because ratings are an average over this interval, they do not necessarily reflect the worst condition encountered. For example, the floor heave rating roughly correlates with the amount that the floor has uplifted. But, with averaging,

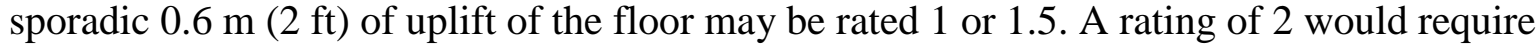
consistent heave in the interval between crosscuts. Subsequent grading of the floor may reduce 
the level of apparent heave, and thus the rating. The results of surveys conducted during the course of this study were intended for characterization and possible subsequent correlation with numerical models, not hazard mapping. In the event of hazard mapping, averaging ratings are not recommended.

Two types of rib deterioration were found suitable for rating. The first was "sloughed," a creation of large onion-skin-like sheets of coal, and the second was "rubblized," coal broken into small pieces. In addition, the rib/roof interface was inspected for detachment (i.e., formation of a gap).

Ribs were consistently bolted and meshed. Sloughed layers were contained by the screen, preventing the accumulation of large slough piles at the base of ribs. Rubblized coal material was often small enough to slip through screen and accumulate. However, rubble was regularly removed from entries. Removal of rubblized coal from the entry floor may change the apparent rating and should be noted. For these reasons, estimated depth of coal loss into the pillar was a more reliable indicator of rib deterioration than accumulation of a slough pile at this mine. Different rib control and entry maintenance practices at other mines may result in different rating criteria. Final rating criteria for the ribs, roof, and floor are presented in Tables 2, 3, and 4, respectively. Ratings were given in 0.5 increments.

When roof deterioration was low, surveys focused on the presence of discontinuities. Subsequently, creation of new tension fractures and the opening of all discontinuities were tracked. Ratings for slickensided discontinuities were increased by one because of inherent weakness in shear. Higher ratings also consider the degree of roof and rib support failure.

\section{Table 2. Final rib rating criteria for Mine A}

\begin{tabular}{|c|c|}
\hline Rating & Description \\
\hline 0 & No sloughing. \\
\hline 1 & $\begin{array}{l}\text { Ribs show minor sloughing, with sloughing extending an average of less than } 0.5 \mathrm{~m}(1.5 \mathrm{ft}) \text { into the rib. } \\
\text { Sloughing appears to be limited to the pillar skin. Large dislodged blocks are not observed or are } \\
\text { infrequent. Rubblized zones are not observed. Rib/roof contacts are largely intact, although minor } \\
\text { separation may occur. }\end{array}$ \\
\hline 2 & $\begin{array}{l}\text { Ribs show moderate sloughing, extending an average of less than } 0.9 \mathrm{~m}(3 \mathrm{ft}) \text { into the ribs. Blocks of } \\
\text { coal may begin to separate from the rib but are not rubblized and remain in place. These blocks may be } \\
\text { slightly rotated, disturbing apparent cleat orientation. The roof/rib interface is often separated on at } \\
\text { least one side. }\end{array}$ \\
\hline 3 & 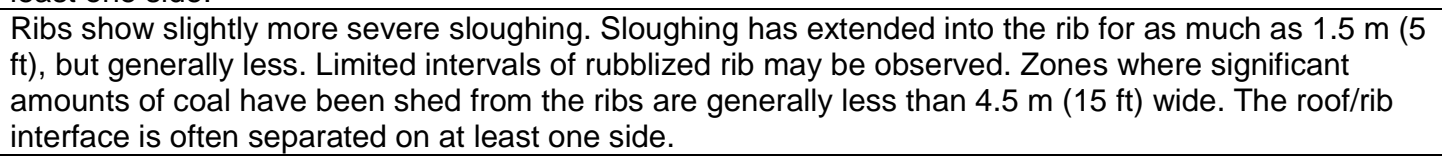 \\
\hline 4 & $\begin{array}{l}\text { Ribs show severe sloughing. Intervals of rubblized rib are extensive, and rubble locally spills out of rib } \\
\text { mesh. Walkways are narrowed by accumulation of shed rib material. Depth of sloughing locally } \\
\text { exceeds } 1.5 \mathrm{~m} \text { ( } 5 \mathrm{ft} \text { ). Mesh and/or rib bolts may be damaged by sloughing rib material. Rib/roof } \\
\text { interfaces have separated. }\end{array}$ \\
\hline 5 & $\begin{array}{l}\text { Ribs show severe sloughing. Accumulated rib material at the Can line is significant- } 0.5 \mathrm{~m}(1.5 \mathrm{ft}) \text { deep } \\
\text { or more. Travel may be unsafe. }\end{array}$ \\
\hline
\end{tabular}


Table 3. Final roof rating criteria for Mine A

\begin{tabular}{l|l}
\hline Rating & Description \\
\hline 0 & $\begin{array}{l}\text { The roof shows no signs of deterioration. There is no sagging, tension cracking, deformation of roof } \\
\text { bolts and mesh, or visible yield in standing support. Joint apertures are tight, and there are no exposed } \\
\text { slicks in the roof. }\end{array}$ \\
\hline 1 & $\begin{array}{l}\text { Tension cracks begin to form; most are parallel or subparallel to entries. Existing joints and newly } \\
\text { formed tension cracks open slightly, with apertures smaller than } 1.3 \mathrm{~cm} \text { (1/2 in). Open joint apertures are } \\
\text { much more common than tension cracks. Tight slickensided discontinuities also justify this rating. } \\
\text { These often occur as concentrations of radial and/or linear slicks, prebolting falls, and other local } \\
\text { geological features. The roof does not sag, and there is no observable yield on roof support. }\end{array}$ \\
\hline 2 & $\begin{array}{l}\text { Tension cracks extend and are more common. Discontinuity apertures open to an average of 1.3 to } 2.5 \\
\text { cm (1/2 to 1 in). Local distortion of roof support may be evident. }\end{array}$ \\
\hline 3 & $\begin{array}{l}\text { Tension cracks and joint apertures open to an average of } 2.5 \text { cm (1 in) or greater. The roof is beginning } \\
\text { to sag locally. Tension cracks are pervasive. Minor, local loss of roof material is apparent in the roof } \\
\text { mesh. Bolt anchorage, however, is unaffected. Roof support may be yielding. }\end{array}$ \\
\hline 4 & $\begin{array}{l}\text { The mesh is visibly bagged with roof rock. Roof failure locally extends to and above the bolting horizon. } \\
\text { Mesh and other support materials are locally damaged by dislodged roof rock. Roof support is yielding. } \\
\text { Roof conditions are locally hazardous. }\end{array}$ \\
\hline 5 & $\begin{array}{l}\text { Roof failure is extensive, not merely local. Bolt anchorage and mesh are at least locally compromised } \\
\text { and have fallen along with broken roof rock. Roof conditions are hazardous through most of the entry. }\end{array}$ \\
\hline
\end{tabular}

\section{Table 4. Final floor rating criteria for Mine A}

\begin{tabular}{l|l}
\hline Rating & Description \\
\hline 0 & There is no visible floor heave, and the floor does not produce a hollow sound. \\
\hline 1 & $\begin{array}{l}\text { The floor may show no visible heave but may produce a hollow sound or there may be very limited } \\
\text { heave. Floor heave may not be continuous throughout the entry and is uplifted by generally } 0.3 \mathrm{~m} \text { (1 } \mathrm{ft}) \\
\text { or less. }\end{array}$ \\
\hline 2 & $\begin{array}{l}\text { There is some limited floor heave. Floor heave is generally less than } 0.8 \mathrm{~m}(2.5 \mathrm{ft}) \text { uplifted and may or } \\
\text { may not be continuous. }\end{array}$ \\
\hline 3 & $\begin{array}{l}\text { Floor heave is more or less continuous throughout the observed area and is uplifted by an average of } \\
0.9 \mathrm{~m}(3 \mathrm{ft}) .\end{array}$ \\
\hline 5 & $\begin{array}{l}\text { Floor heave is continuous throughout the observed area and is uplifted by greater than } 0.6 \mathrm{~m}(2 \mathrm{ft}) \text { but } \\
\text { less than } 1.4 \mathrm{~m}(4.5 \mathrm{ft}) .\end{array}$ \\
\hline
\end{tabular}

The photograph in Figure 7 is an example of "rating 3" roof deterioration. Although no tension cracks are visible in the photograph, the roof is clearly sagging. Rubblized roof material is contained in the mesh, causing it to bulge outward.

The photograph in Figure 8 is an example of "rating 1.5." rib deterioration. The rib is sloughing less than $0.5 \mathrm{~m}(1.5 \mathrm{ft})$ of material, which is effectively contained in the rib mesh. The dislodged material has detached in large slabs and has not rubblized.

The photograph in Figure 9 is an example of "rating 4" floor deterioration. Floor heave in the

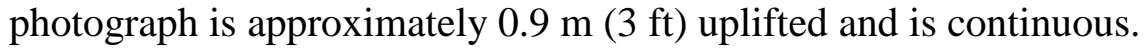

Because these are surveys, though observations are reportable as measurements, results are found in the Measurements section of this report. 


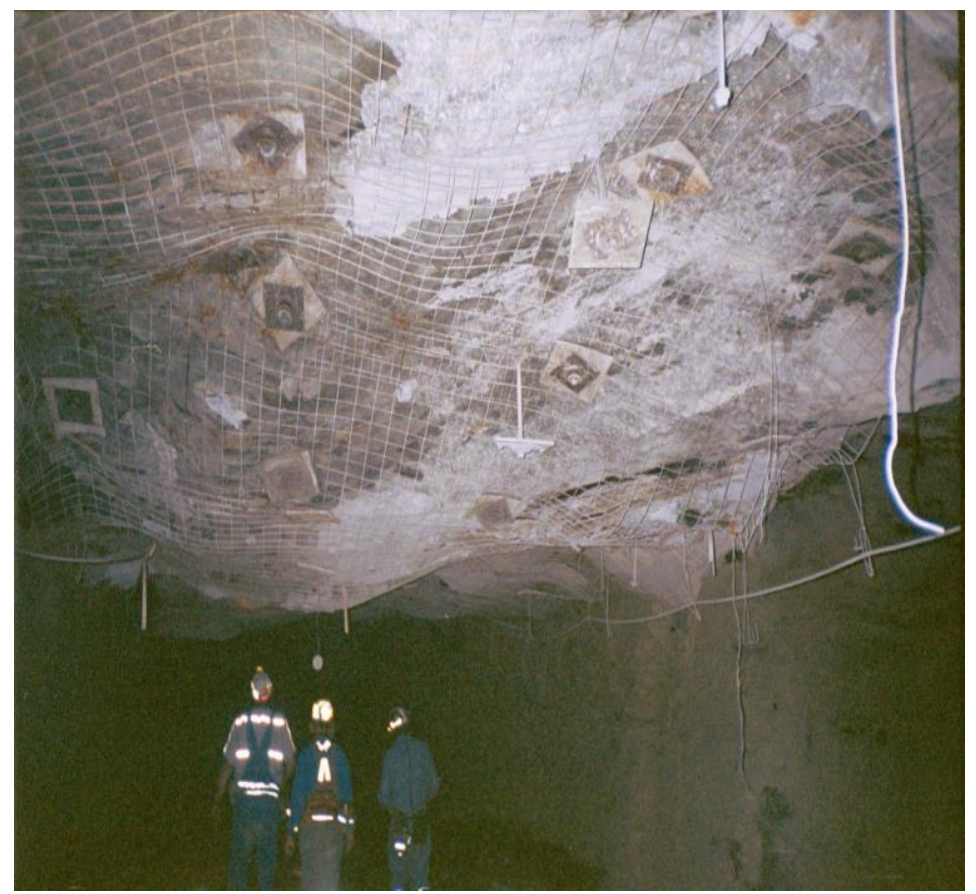

Figure 7. Sample photograph of rating 3 roof deterioration. The roof is sagging greatly in places and appears loose-only held up by mesh and roof bolts.

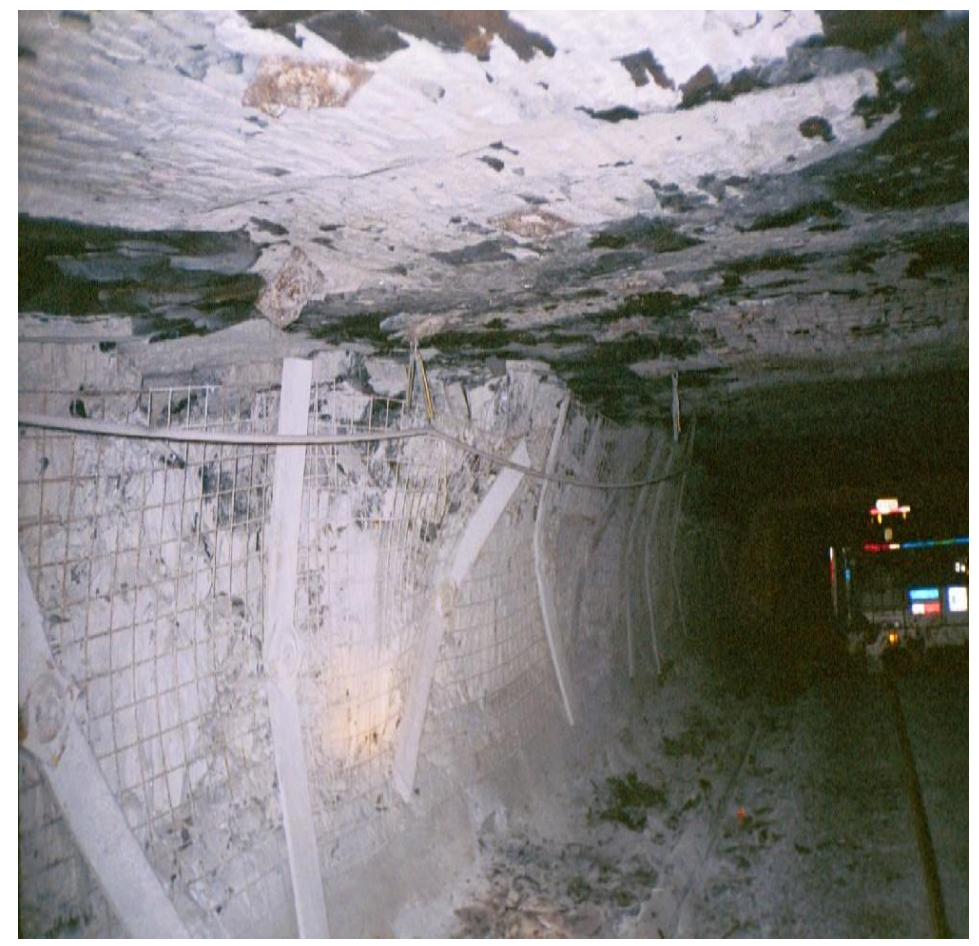

Figure 8. Sample photograph of rating 1.5 rib deterioration. 


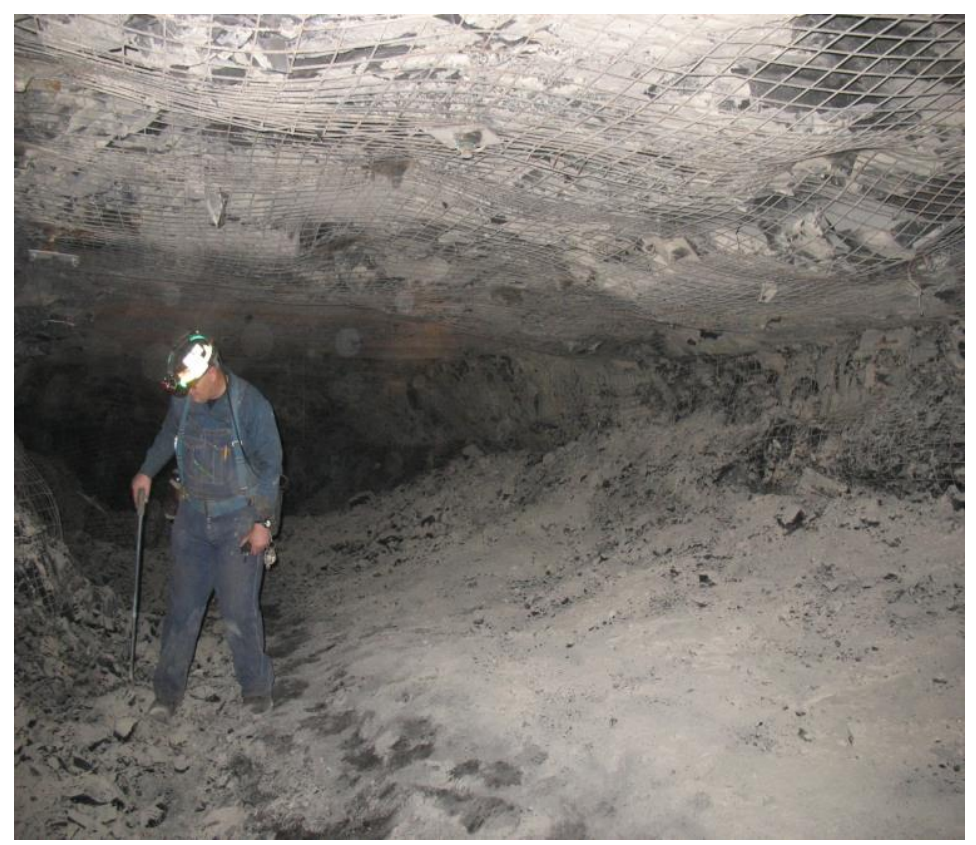

Figure 9. Sample photograph of rating 4 floor heave.

\section{Floor Heave}

Even without quantifying movement of the floor through ground condition surveys, it was obvious to the casual observer that floor heave in the 1 North gate roads of Mine A was generally insignificant (see Figure 10), whereas floor heave in the 2 North gate roads was very significant (see Figure 11). As the face approached, floor heave generally occurred within at least two crosscuts outby the face. Although support Cans were used to help prevent entry closure, floor heave was significant enough that floor rubble cleanup was almost constantly in motion. This observation was verified with ground condition surveys, as reported in the Measurements section of this report. 


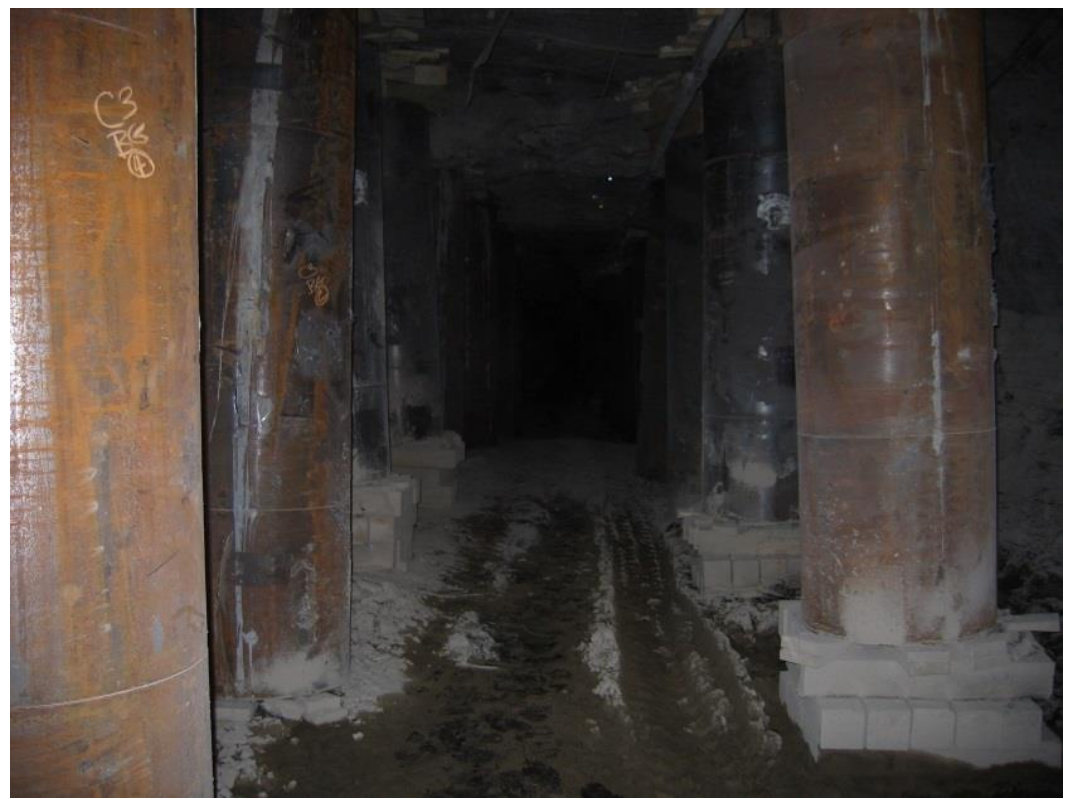

Figure 10. View of entry 3 at crosscut 10 in 1 North, showing a typical 1 North condition of no significant floor heave.

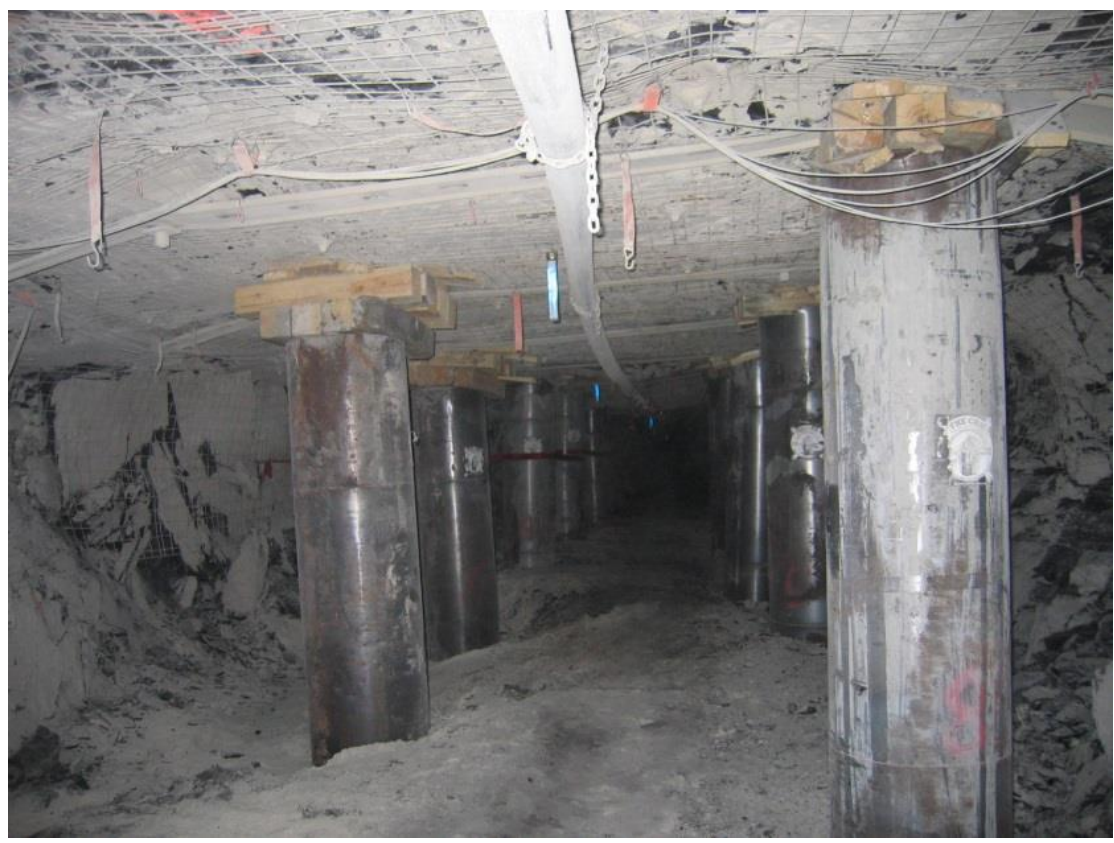

Figure 11. View of entry 2 at crosscut 30 in 2 North, showing typical floor heave as the face approached. 
Mine B

\section{Observations of Drilling}

At Mine B, drilling was not accomplished the same way as at Mine A. Because of the lack of water and compressed air lines at the mine, holes were drilled by the mine and NIOSH personnel using a handheld Turmag drill with an auger bit. Moreover, the borehole pressure cells were not pre-encapsulated; therefore, a comparison of installation difficulty as a result of hole closure could not be determined.

\section{Ground Condition Surveys}

The following deterioration index scale in Tables 5, 6, and 7 was created as a prototype for observation at Mine B, with the understanding that certain aspects of it would be significantly altered as the project progressed. It is similar to the scale used for Mine A but has taken into account some of the variation in local geotechnical factors that were anticipated to affect ground behavior. Observation using this tool, however, was relatively limited, and this prototype was never modified during the course of the project.

Table 5. Final rib rating criteria for Mine B

\begin{tabular}{l|l}
\hline Rating & Description \\
\hline 0 & No sloughing. \\
\hline 1 & $\begin{array}{l}\text { Ribs show minor sloughing, with sloughing extending an average of less than } 0.3 \mathrm{~m} \text { (1 ft) into the rib. } \\
\text { Sloughing appears to be limited to the pillar skin. Large dislodged blocks are not observed or are } \\
\text { infrequent. Rubblized zones are not observed. }\end{array}$ \\
\hline 2 & $\begin{array}{l}\text { Ribs show moderate sloughing, extending an average of less than 1 } \mathrm{m} \text { (3 ft) into the ribs. Sloughing } \\
\text { appears to be limited to the pillar skin. Large dislodged blocks are not observed or are infrequent. } \\
\text { Rubblized zones are not observed. }\end{array}$ \\
\hline 3 & $\begin{array}{l}\text { Ribs show slightly more severe sloughing. Sloughing has extended into the rib for as much as } 1.5 \mathrm{~m} \text { (5 } \\
\mathrm{ft}), \text { but generally less. Limited intervals of rubblized rib may be observed. Zones where significant } \\
\text { amounts of coal have been shed from the ribs are generally less than 4.6 m (15 ft) wide. }\end{array}$ \\
\hline 5 & $\begin{array}{l}\text { Ribs show severe sloughing. Intervals of rubblized rib are extensive, and rubble locally spills out of rib } \\
\text { mesh. Walkways are narrowed by accumulation of shed rib material. Depth of sloughing locally } \\
\text { exceeds } 1.5 \mathrm{~m} \text { (5 ft). Mesh and/or rib bolts may be damaged by sloughing rib material. }\end{array}$ \\
\hline 5 & $\begin{array}{l}\text { Ribs show severe sloughing. Accumulated rib material at the Can line is significant and is generally } \\
0.46 \mathrm{~m}(1.5 \mathrm{ft}) \text { deep or more. Travel may be unsafe. }\end{array}$ \\
\hline
\end{tabular}


Table 6. Final roof rating criteria for Mine B

\begin{tabular}{l|l}
\hline Rating & Description \\
\hline 0 & $\begin{array}{l}\text { The roof shows no signs of deterioration. There is no sagging, tension cracking, deformation of roof } \\
\text { bolts and mesh, or visible yield in standing support. Joint or cleat apertures are tight and there are no } \\
\text { exposed slicks in the roof. }\end{array}$ \\
\hline 1 & $\begin{array}{l}\text { Tension cracks begin to form. Existing joints/cleats and newly formed tension cracks open slightly, with } \\
\text { apertures smaller than } 1.3 \mathrm{~cm}(0.5 \text { in). Open joint/cleat apertures are much more common than tension } \\
\text { cracks. Tight slickensided discontinuities also justify this rating. The roof does not sag and there is no } \\
\text { observable yield on roof support. }\end{array}$ \\
\hline 3 & $\begin{array}{l}\text { Tension cracks extend and are more common. Discontinuity apertures open to an average of 1.3 to } 2.5 \\
\text { cm (0.5 to 1 in). Local distortion of roof support may be evident. }\end{array}$ \\
\hline 4 & $\begin{array}{l}\text { Tension cracks and joint/cleat apertures open to an average of 2.5 cm (1 in) or greater. The roof is } \\
\text { beginning to sag locally. Cracks and open cleats are pervasive. Minor, local loss of roof material is } \\
\text { apparent in the roof mesh. Bolt anchorage, however, is unaffected. Roof support may be yielding. }\end{array}$ \\
\hline $\begin{array}{l}\text { The mesh is visibly bagged with roof rock. Roof failure locally extends to and above the bolting horizon. } \\
\text { Mesh and other support materials are locally damaged by dislodged roof rock. Roof support is yielding. } \\
\text { Roof conditions are locally hazardous. }\end{array}$ \\
\hline 5
\end{tabular}

Table 7. Final floor rating criteria for Mine B

\begin{tabular}{|c|c|}
\hline Rating & Description \\
\hline 0 & There is no visible floor heave, and the floor does not produce a hollow sound. \\
\hline 1 & $\begin{array}{l}\text { The floor may show no visible heave but may produce a hollow sound or there may be very limited } \\
\text { heave. Floor heave may not be continuous throughout the entry and is uplifted by generally } 0.3 \mathrm{~m}(1 \mathrm{ft}) \\
\text { or less. }\end{array}$ \\
\hline 2 & $\begin{array}{l}\text { There is some limited floor heave. Floor heave is generally less than } 0.76 \mathrm{~m}(2.5 \mathrm{ft}) \text { uplifted and may or } \\
\text { may not be continuous. }\end{array}$ \\
\hline 3 & $\begin{array}{l}\text { Floor heave is more or less continuous throughout the observed area and is uplifted by an average of } \\
1.5 \mathrm{~m}(3 \mathrm{ft}) \text {. }\end{array}$ \\
\hline 4 & $\begin{array}{l}\text { Floor heave is continuous throughout the observed area and is uplifted by greater than } 0.6 \mathrm{~m}(2 \mathrm{ft}) \text { but } \\
\text { less than } 1.4 \mathrm{~m}(4.5 \mathrm{ft}) \text {. }\end{array}$ \\
\hline 5 & Floor heave is continuous and uplifted by greater than $1.4 \mathrm{~m} \mathrm{(4.5 \textrm {ft } ) .}$ \\
\hline
\end{tabular}

\section{Instruments Installed}

Mine A

Several instruments were installed as part of this study in four locations - two each in the 1 North gate roads and in the 2 North gate roads. Figure 3 shows the location of these sites. In each set of gate roads, the two sites were distinguished by the designations of "inby" and "outby." Thus, the sites were called 1 North inby, 1 North outby, 2 North inby, and 2 North outby sites. Each of these sites had arrays of instruments. Table 8 lists the instruments installed at each site and how each was measured. As noted earlier, AAI designed the BPC instrumention plan. NIOSH personnel from both the Spokane and Pittsburgh offices added extensometers, sonic probes, closure meters, instrumented cans, and dataloggers to the plan. An AAI crew installed the BPCs. NIOSH crews from the Spokane and Pittsburgh offices installed all other instruments. 
However, mine personnel used the roof bolter to drill the upholes for instruments installed in the roof.

Table 8. Instruments installed at test sites at Mine A

\begin{tabular}{|c|c|c|c|c|c|}
\hline Instrument & $\begin{array}{c}\text { Number } \\
\text { installed at } \\
1 \text { North inby } \\
\text { site }\end{array}$ & $\begin{array}{c}\text { Number } \\
\text { installed at } 2 \\
\text { North inby } \\
\text { site }\end{array}$ & $\begin{array}{c}\text { Number } \\
\text { installed at } 1 \\
\text { North outby } \\
\text { site }\end{array}$ & $\begin{array}{c}\text { Number } \\
\text { installed at } 2 \\
\text { North outby } \\
\text { site }\end{array}$ & $\begin{array}{c}\text { How } \\
\text { measured }\end{array}$ \\
\hline $\begin{array}{l}\text { Borehole } \\
\text { pressure cell }\end{array}$ & 13 & 17 & 13 & 17 & $\begin{array}{c}\text { Campbell } \\
\text { Scientific } \\
21 X Q M \\
\text { datalogger }\end{array}$ \\
\hline Closure station & 8 & 5 & 7 & 8 & $\begin{array}{c}\text { Tape } \\
\text { extensometer, } \\
\text { manually }\end{array}$ \\
\hline $\begin{array}{c}\text { 3-point MPBX in } \\
\text { roof }\end{array}$ & 0 & 4 & 0 & 0 & $\begin{array}{l}\text { Readout box, } \\
\text { manually }\end{array}$ \\
\hline $\begin{array}{c}\text { Three-point } \\
\text { string } \\
\text { potentiometer } \\
\text { extensometer in } \\
\text { roof }\end{array}$ & 0 & 0 & 5 & 5 & $\begin{array}{c}\text { Campbell } \\
\text { Scientific } \\
21 X Q M \\
\text { datalogger }\end{array}$ \\
\hline $\begin{array}{l}\text { 16-point sonic } \\
\text { probe }\end{array}$ & 0 & 0 & 2 & 2 & $\begin{array}{l}\text { Readout box, } \\
\text { manually }\end{array}$ \\
\hline $\begin{array}{l}\text { Instrumented } \\
\text { support Can }\end{array}$ & 0 & 0 & 0 & 10 & $\begin{array}{c}\text { Campbell } \\
\text { Scientific } \\
20 X Q M \\
\text { datalogger }\end{array}$ \\
\hline
\end{tabular}

Figure 12 is a sketch of locations of instruments installed at the 1 North inby site. Because installation took place around the same time as the start of Panel 1 mining, the emphasis was placed on installing BPCs. BPC target pressures for initialization were determined by using an average overburden pressure of $0.02488 \mathrm{MPa} / \mathrm{m}(1.100 \mathrm{psi} / \mathrm{ft})$ of overburden depth. Cells were manually pressurized to the target pressure using an in-line dial gauge as reference. Pressure in each of the cells was monitored with a pressure transducer whose measureable range of 0 to 15,000 psi was indicated in the range of $0.5 \mathrm{~V}$ to $5.5 \mathrm{~V}$. This voltage was reduced with a 11:10 ratio voltage divider at the datalogger so that the readable range was $0.4545 \mathrm{~V}$ to $5.000 \mathrm{~V}-$ thereby the maximum of the reduced instrument range matched the maximum readable range of the datalogger. Figure 13 shows a datalogger used to monitor instruments at one of the sites. Sensitivity of the datalogger in that range of the pressure transducers corresponded to approximately $13.8 \mathrm{kPa}(2 \mathrm{psi})$. Figure 14 is a photograph of an example plumbing configuration of manifold blocks with hydraulic gauge and pressure transducer mounted on the rib near the collar of boreholes. The only other instruments installed at the 1 North inby instrumentation site were closure points, executed by a crew from Agapito and Associates, consisting of floor anchor points located directly below a roof bolt. These points were checked infrequently with a manual tape extensometer. 


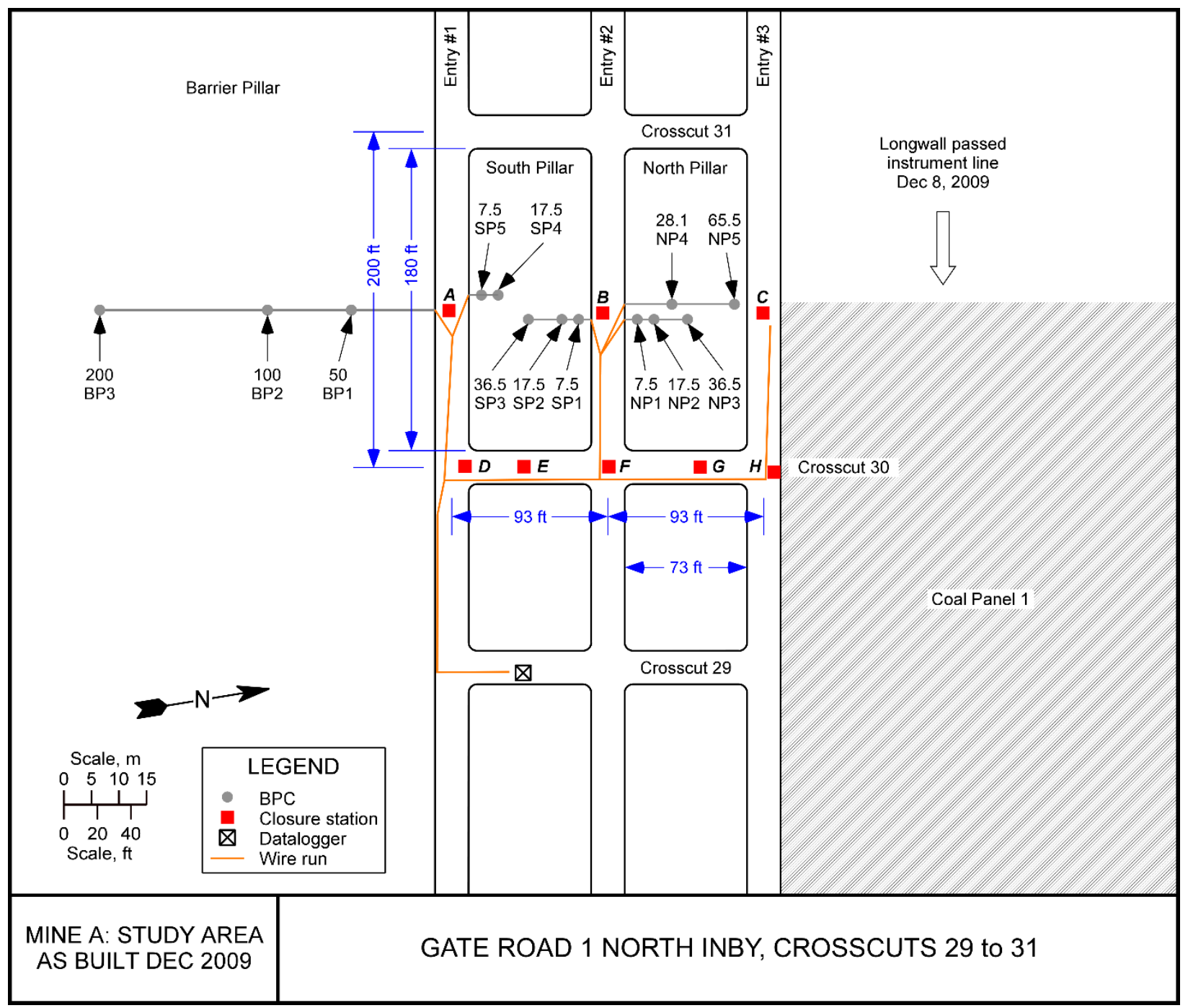

Figure 12. Instrumentation as installed at the 1 North inby site. Pillars between crosscuts 29 and $\mathbf{3 0}$ have incorrect lengths by scale. They have the same lengths as the other pillars. 


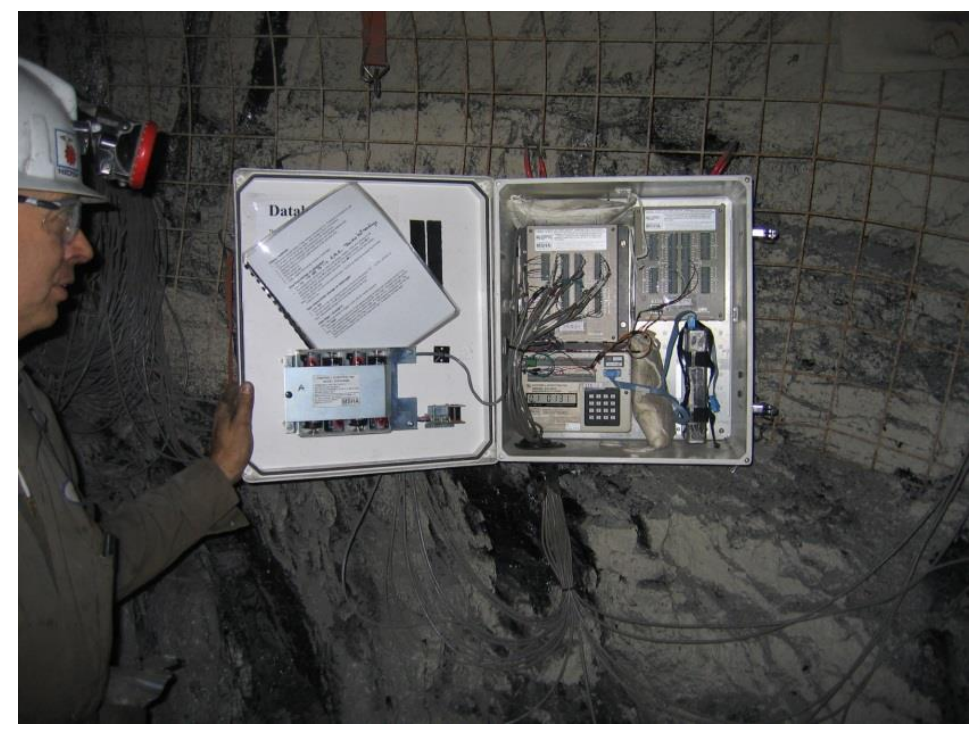

Figure 13. Enclosure with Campbell Scientific 21XQM datalogger and components for reading BPC pressure transducers and the string potentiometers of roof extensometers.

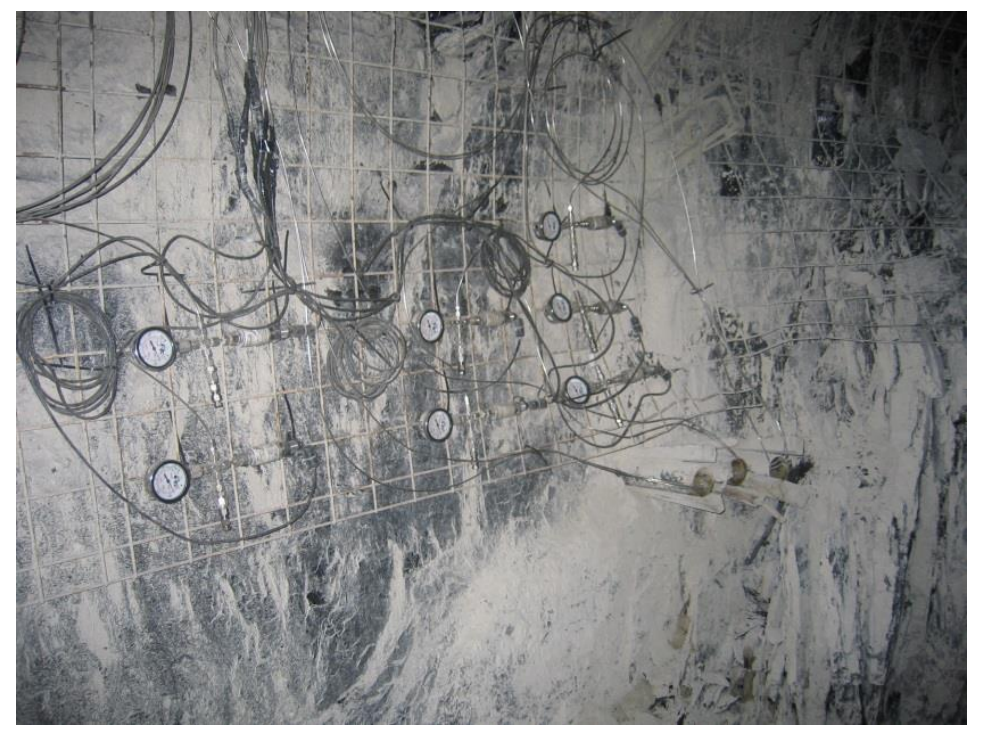

Figure 14. Hydraulic lines, manifolds, hydraulic gauges, pressure transducers, and cabling installed on the rib near the collars of BPC boreholes at the 2 North inby site.

Figure 15 shows the location of instruments installed at the 2 North inby site. In addition to BPCs and closure stations, MPBXs were installed. These extensometers had up-hole mechanical

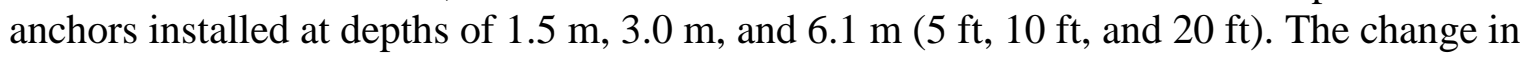
distance between the collar and each anchor was measured manually with a dial gauge. 


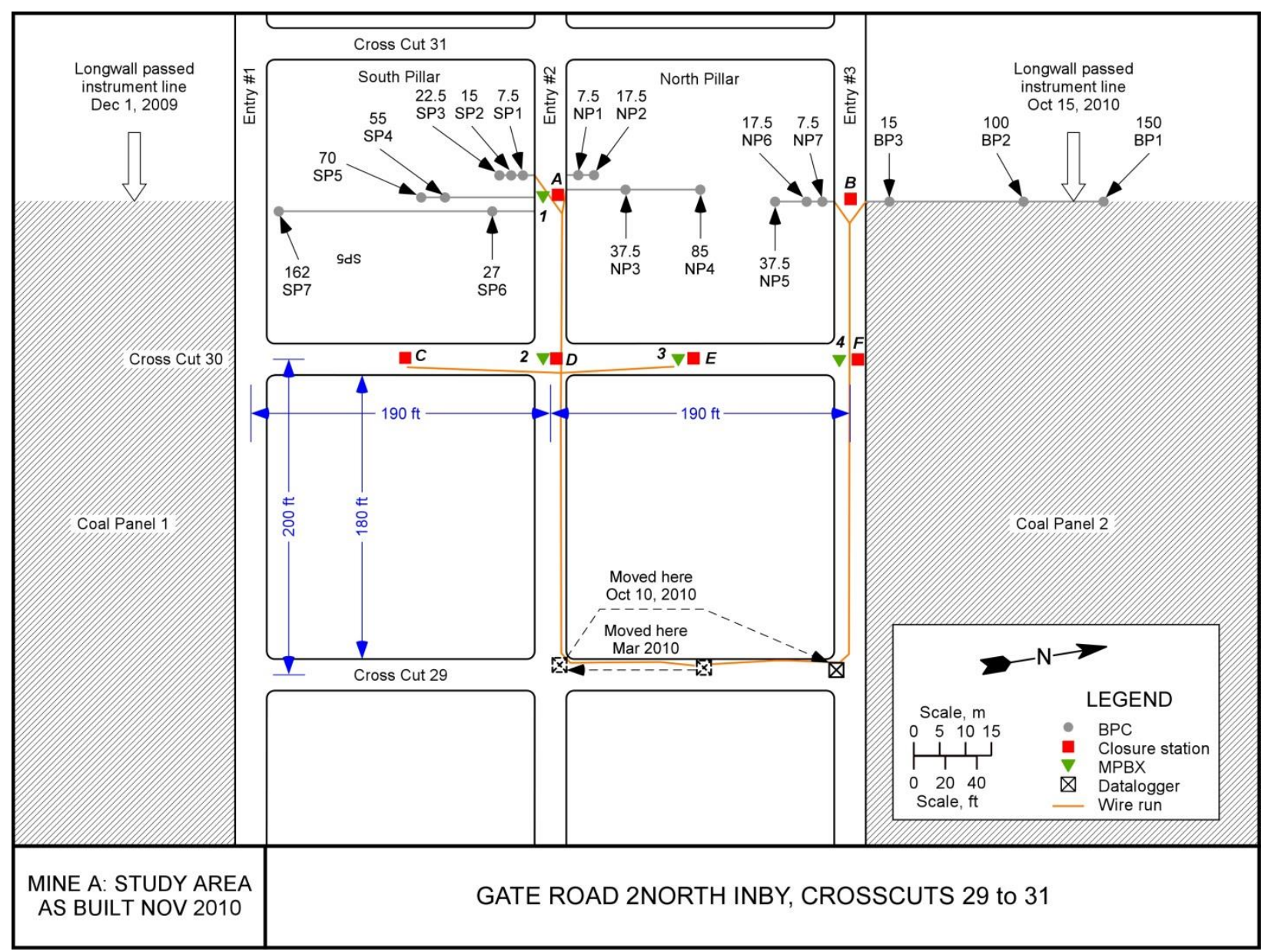

Figure 15. Instrumentation as installed at the 2 North inby site.

Figure 16 shows the location of instruments installed at the 1 North outby site. This site was installed when the Panel 1 face was 790 to 1,065 $\mathrm{m} \mathrm{(2,600} \mathrm{to} \mathrm{3,500} \mathrm{ft)} \mathrm{away-well} \mathrm{beyond} \mathrm{what}$ one might reasonably expect to be the range of influence of panel mining on redistribution of stress. Therefore, roof extensometers that could be monitored more frequently by a datalogger were assembled, installed, and monitored instead of manually read MPBXs. These instruments, shown installed in Figure 17, involved a collar assembly holding string potentiometers that were bolted to the roof near the collar with small anchors. Stiff spring anchors were placed up an EX (approximately 38-mm-diameter [1.5-in-diameter]) hole at the same nominal depths as were the MPBX anchors at the 2 North inby site. Piano wire ran separately from each anchor to an individual string potentiometer outside the collar of the borehole. Cables ran to the datalogger for monitoring the string potentiometers. Two sonic probes were installed in $6.1-\mathrm{m}$-deep (20-ftdeep) holes. Anchors with magnets around the probe sleeve were installed such that the first anchor was placed at a depth of about $3.3 \mathrm{~cm}$ (8.5 in), anchors 2 through 10 were roughly spaced at 4.7-cm (12-in) intervals, and anchors 11 through 16 were placed at approximately $7.1-\mathrm{cm}$ (18in) intervals. Anchor positions of the sonic probes were monitored infrequently with a manual sonic probe readout box. 


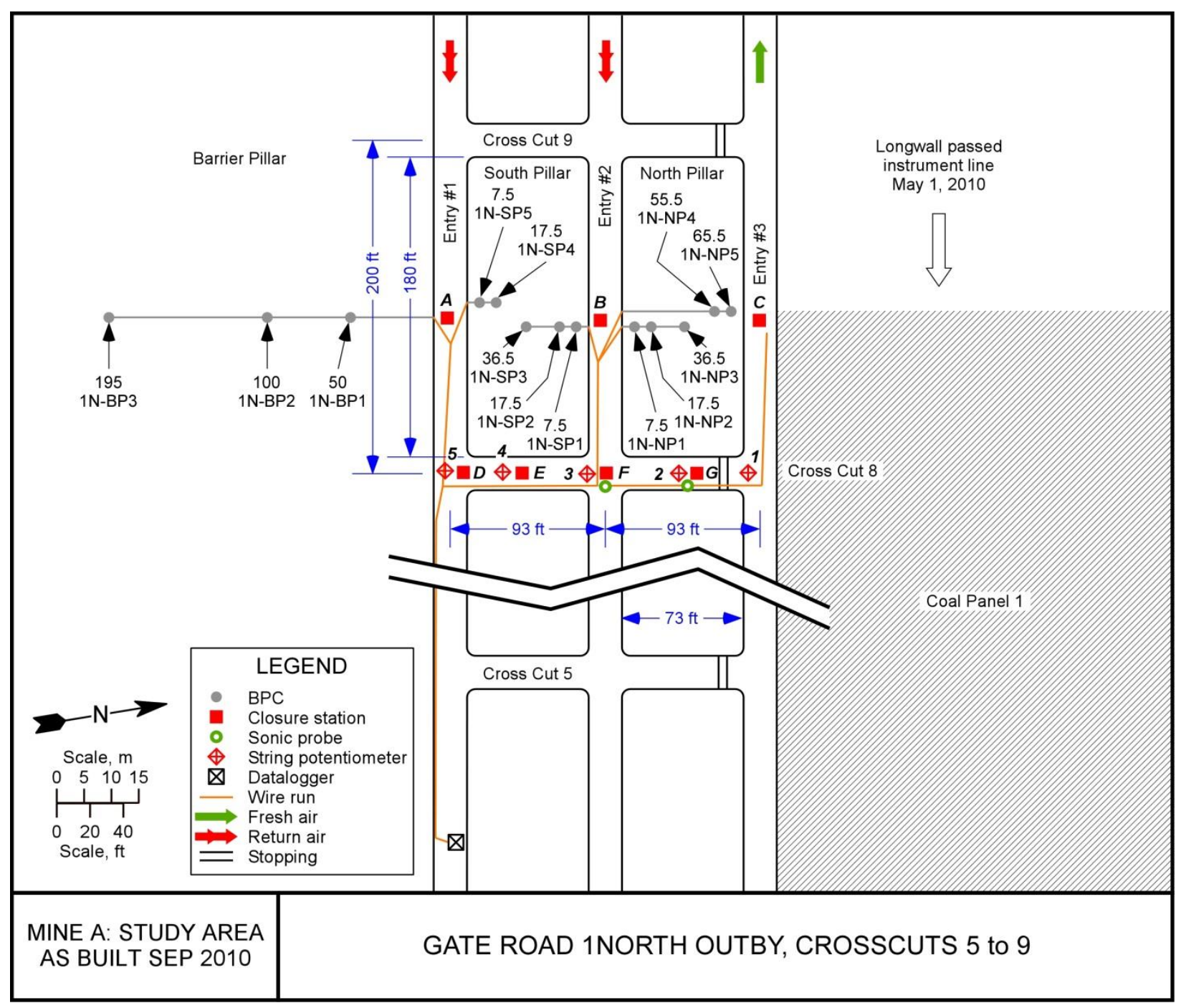

Figure 16. Instrumentation as installed at the 1 North outby site. 


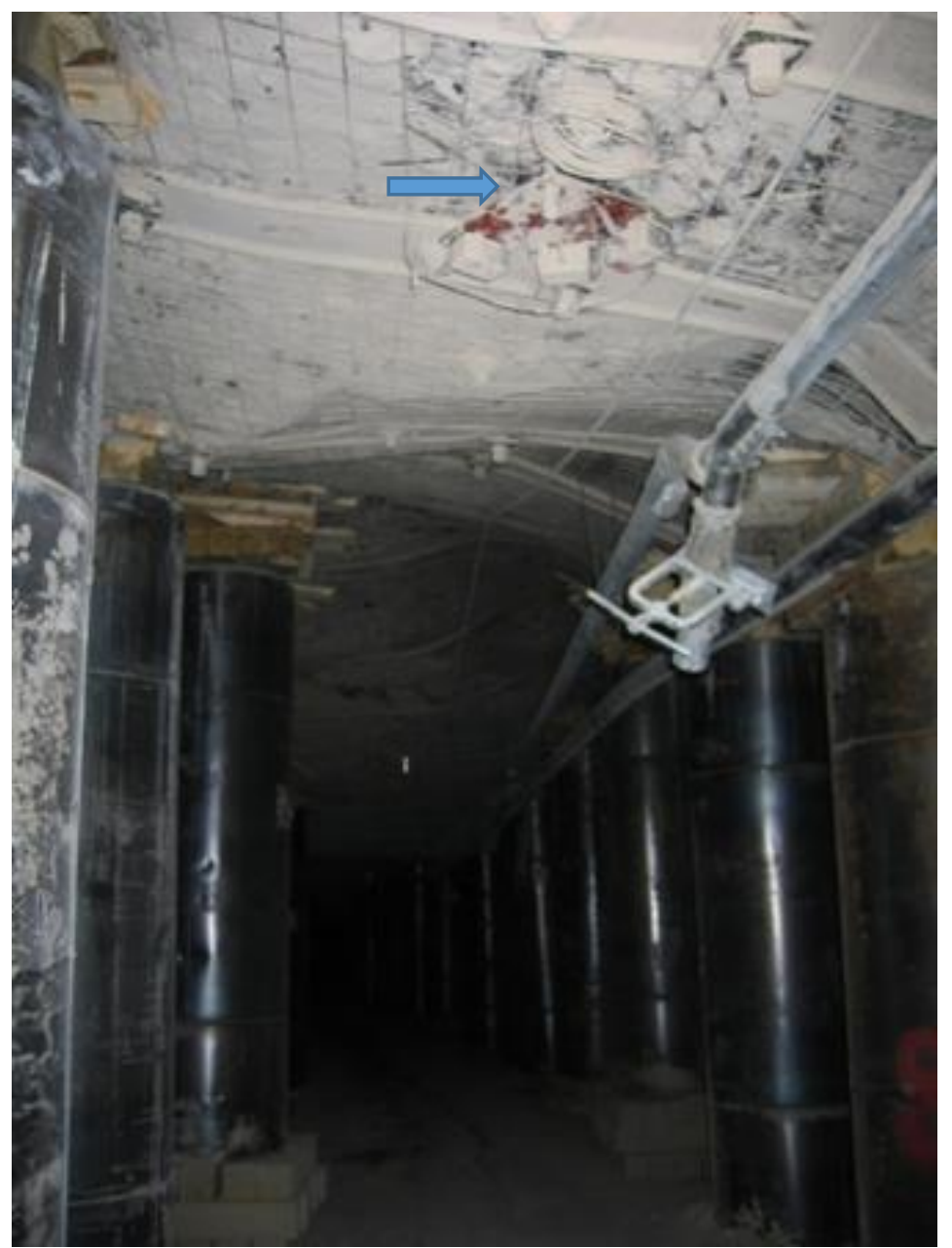

Figure 17. Installed three-point roof extensometer (indicated with blue arrow) with string potentiometers mounted on red collar brackets that are partially covered with rock dust.

Figure 18 shows locations of instruments installed at the 2 North outby site. The same instrument types used at the 1 North outby site were installed at this site with some modifications in location. The BPC installation was especially troublesome even before drilling was completed at this site because loading of the coal and deteriorating coal conditions caused the BX (60-mmdiameter [2.36-in-diameter]) holes to not maintain their shape to the degree that sometimes the BPCs could not be placed at the desired locations. BPCs labeled SP6 and BP1 had to be installed well short of target locations. 


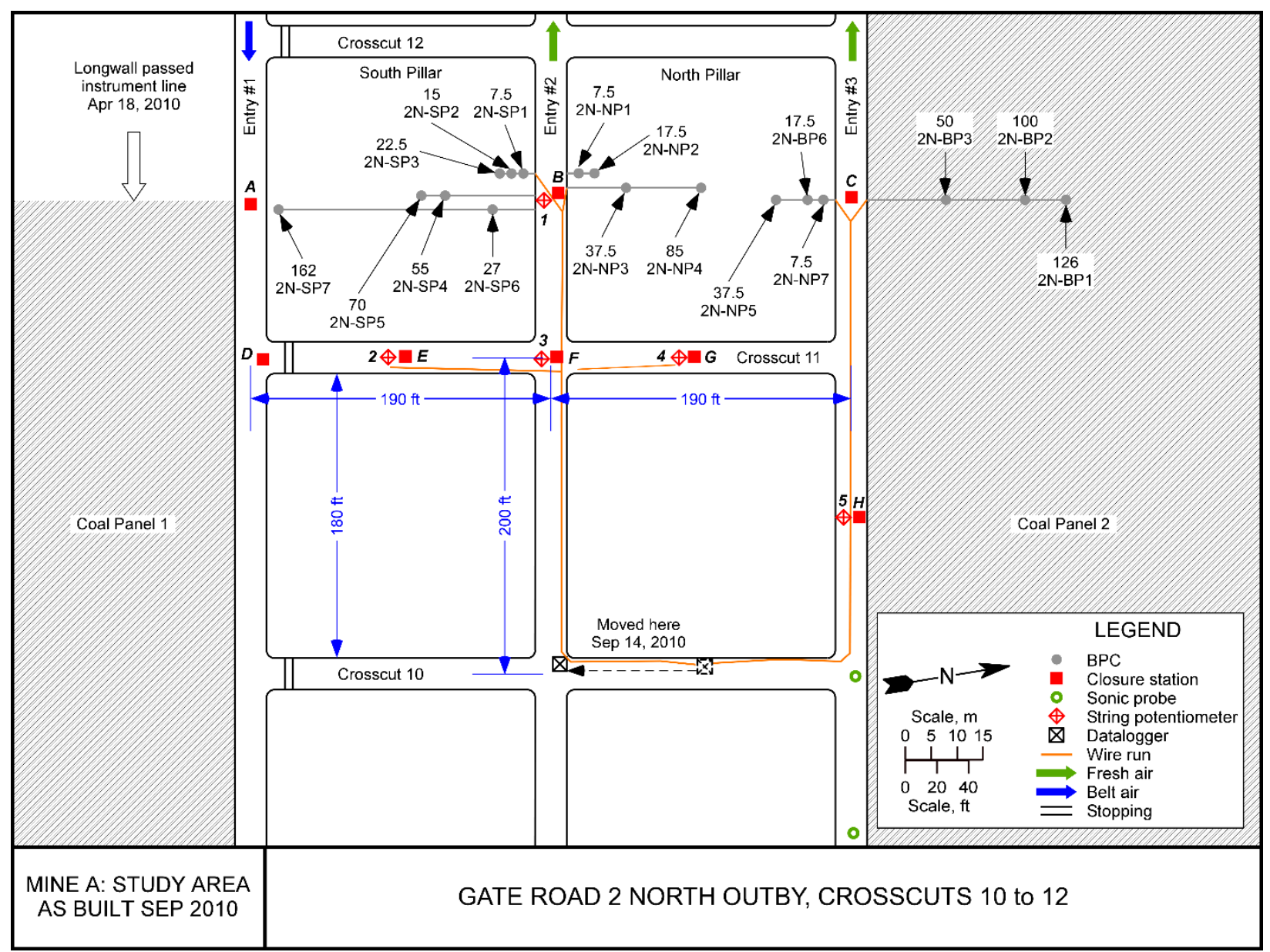

Figure 18. Instrumentation as installed at the 2 North outby site.

Figure 19 shows locations of instrumented support Cans in entry 3 near the main part of the 2 North outby instrumentation site. These Cans were $11.0 \mathrm{~cm}$ (28 in) or $11.8 \mathrm{~cm}$ (30 in) in diameter. A bladder was placed between two thick plates of plywood in line with the Can and wooden cribs and wedges at the top of the Cans. Pressure transducers monitored hydraulic pressure in the bladders, but the transducers were calibrated to load in tonnes (tons) at the NIOSH Mine Roof Simulator test facility in Bruceton, PA. 


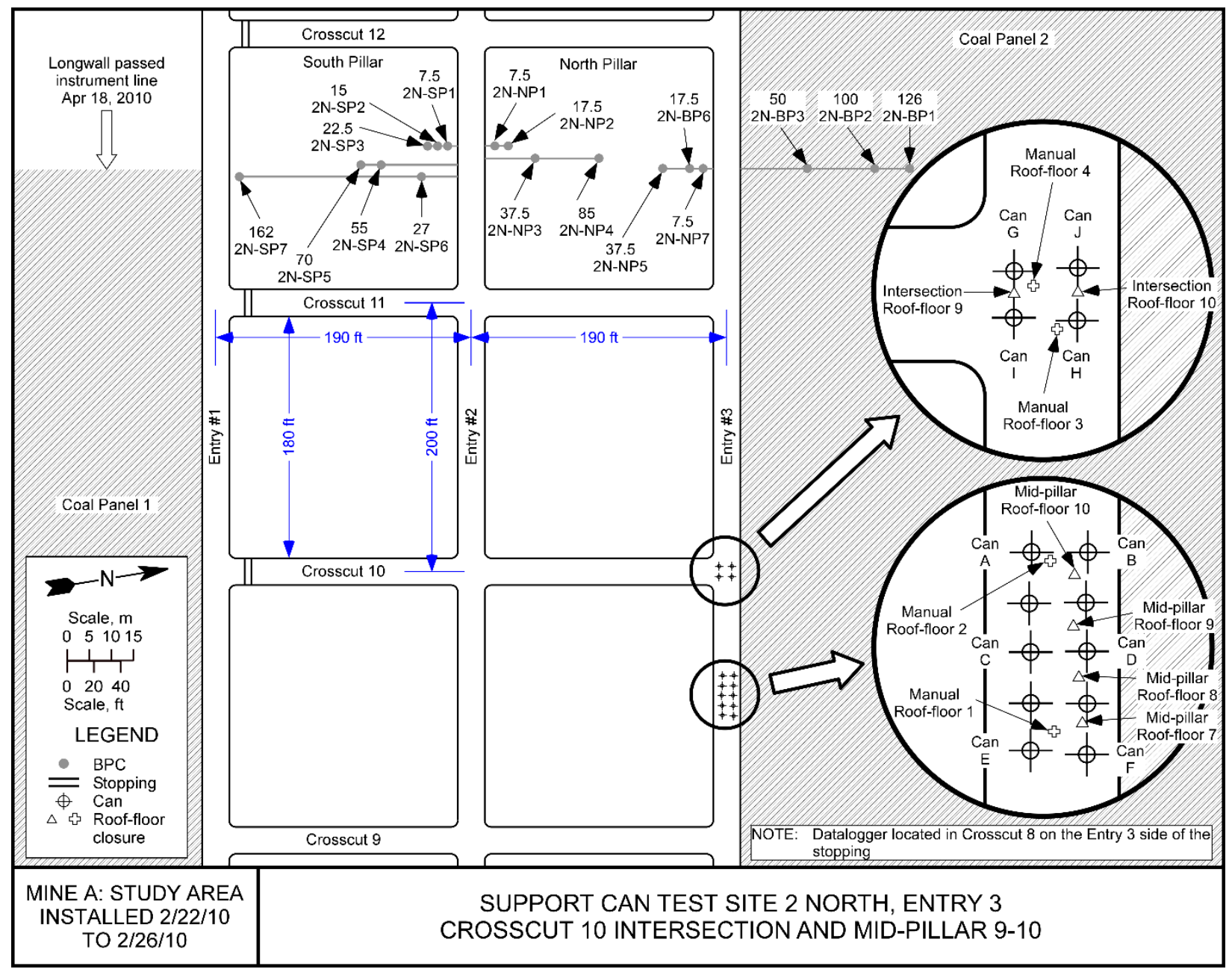

Figure 19. The 2 North outby instrumentation site at Mine A showing locations of instrumented support Cans and their labels identified in zoomed-in sketches. Also shown are locations of roof-to-floor closure stations.

Mine B

The instrumentation plan at Mine B was somewhat experimental. After the experience of measurements at Mine A, it was decided to include essential elements of the Mine A plan (i.e., BPCs and instrumented support Cans), but also to further test whether Can closure might be feasible as an indicator of the arrival of abutment stress resulting from mining. In addition, the idea was appealing of spreading out the locations in the gate road systems where distance to first arrival of abutment stress was measured instead of concentrating all measurements at one or two sites. These ideas were considered and an instrumentation plan was designed and installed by NIOSH personnel from the Spokane office. Mine engineers were in agreement with the plan. Mine engineering personnel assisted with the installation, including drilling with the Turmag drill.

Testing of this concept was initiated in the headgate and tailgate of the B-11 panel at stations T5-6 and T15-16 (called Phase 1 installations), as indicated in Figure 5, but the panel was partially mined, and no good baseline was established for that panel. 
Table 9 lists the instruments installed at each site. More instrumented stations with multiple kinds of instruments were installed well ahead of the mining face for the B-12 panel. These instruments included BPCs, support Can closures and entry closures in the tailgate, instrumented support Cans in the headgate (load), and roof extensometers and rib extensometers at the $\mathrm{H} 42$ and $\mathrm{H} 43$ stations in the headgate. Closure stations were originally planned for the headgate stations but were not carried out. Figures 20-24 show the instruments installed and their locations at the T39, T33-34, T20-21, H42-43, and H21-22 sites, respectively. A measurement station was also installed at T28 in the B-12 panel tailgate, but it was considered a "leapfrog" station with only closure measurements conducted. The instruments were only monitored for a short time, and the data were not consistent or useful, and therefore, are not reported here.

Table 9. Instruments installed at test sites at Mine B

\begin{tabular}{|c|c|c|c|c|c|c|c|c|}
\hline Instrument & T5-6 & $\begin{array}{l}\text { T15- } \\
16\end{array}$ & T39 & $\begin{array}{l}\text { T33- } \\
34\end{array}$ & $\begin{array}{l}\text { T20- } \\
21\end{array}$ & $\begin{array}{l}\mathrm{H} 42- \\
43\end{array}$ & $\begin{array}{l}\mathrm{H} 21- \\
22\end{array}$ & How read \\
\hline BPCs & 0 & 0 & 0 & 5 & 6 & 5 & 5 & $\begin{array}{l}\text { MIDAS } \\
\text { datalogger }\end{array}$ \\
\hline Support Cans & 0 & 0 & 0 & 0 & 0 & 4 & 4 & \begin{tabular}{|l|} 
MIDAS \\
datalogger
\end{tabular} \\
\hline $\begin{array}{l}\text { Closure string } \\
\text { potentiometers } \\
\text { on Cans }\end{array}$ & 5 & 5 & 2 & 2 & 4 & 0 & 0 & $\begin{array}{l}\text { MIDAS } \\
\text { datalogger }\end{array}$ \\
\hline $\begin{array}{l}\text { Closure string } \\
\text { potentiometers in } \\
\text { entry }\end{array}$ & 2 & 0 & 2 & 2 & 4 & 0 & 0 & $\begin{array}{l}\text { MIDAS } \\
\text { datalogger }\end{array}$ \\
\hline Manual closure & 4 & 1 & 2 & 4 & 4 & 0 & 0 & \begin{tabular}{|l|} 
Tape \\
extensometer
\end{tabular} \\
\hline $\begin{array}{l}\text { 3-point roof } \\
\text { extensometers }\end{array}$ & 0 & 0 & 0 & 0 & 0 & 2 & 0 & \begin{tabular}{|l|} 
MIDAS \\
datalogger
\end{tabular} \\
\hline $\begin{array}{l}\text { 4-point rib } \\
\text { extensometers }\end{array}$ & 0 & 0 & 0 & 0 & 0 & 1 & 0 & $\begin{array}{l}\text { MIDAS } \\
\text { datalogger }\end{array}$ \\
\hline
\end{tabular}

MIDAS = Miniature data acquisition system [Sunderman et al. 2003; Jones 2012] 


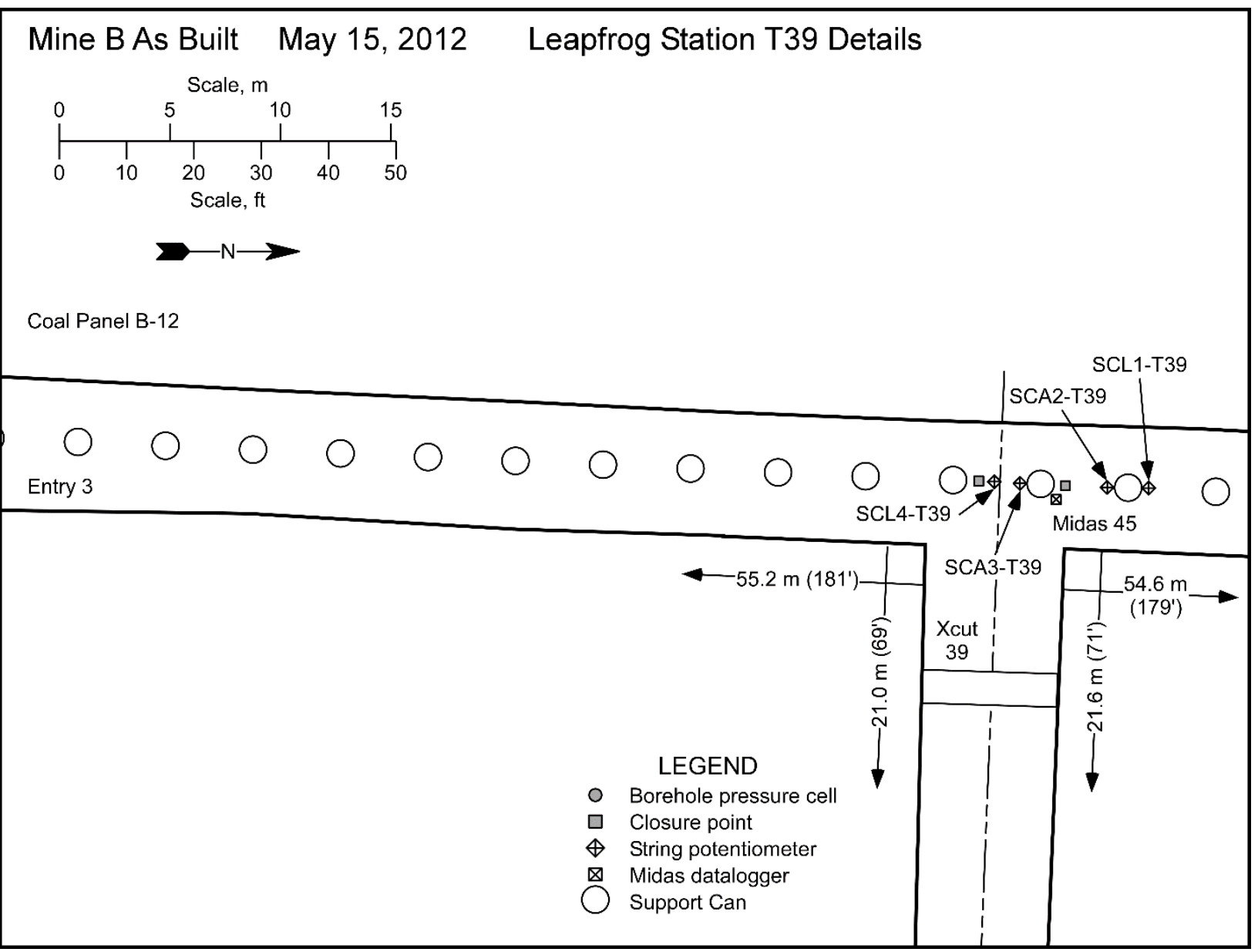

Figure 20. Map showing detail of instruments installed at the T39 station in the tailgate of the B-12 panel at Mine B. 


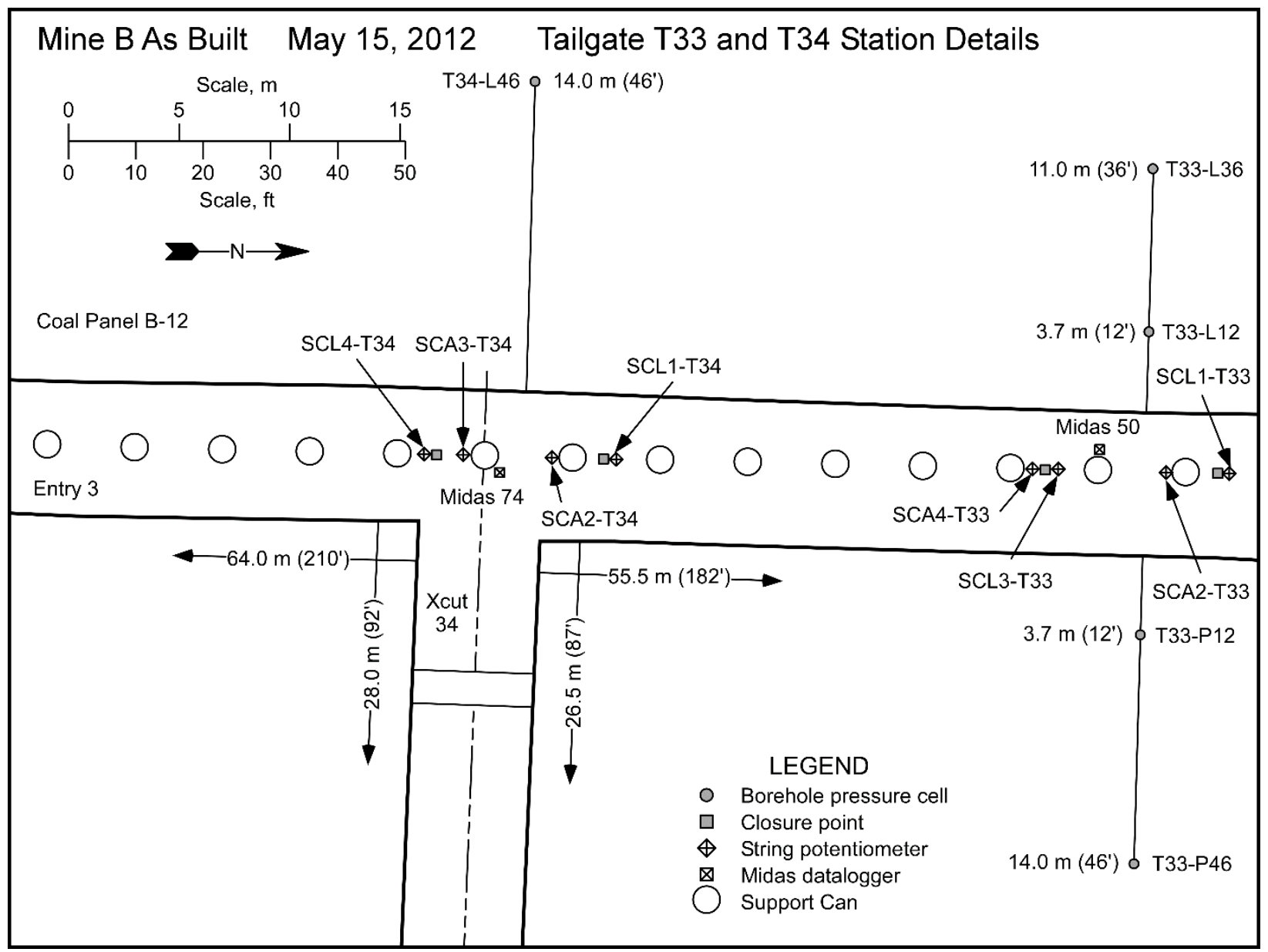

Figure 21. Map showing detail of instruments installed at the T33 and T34 stations in the tailgate of the B-12 panel. 


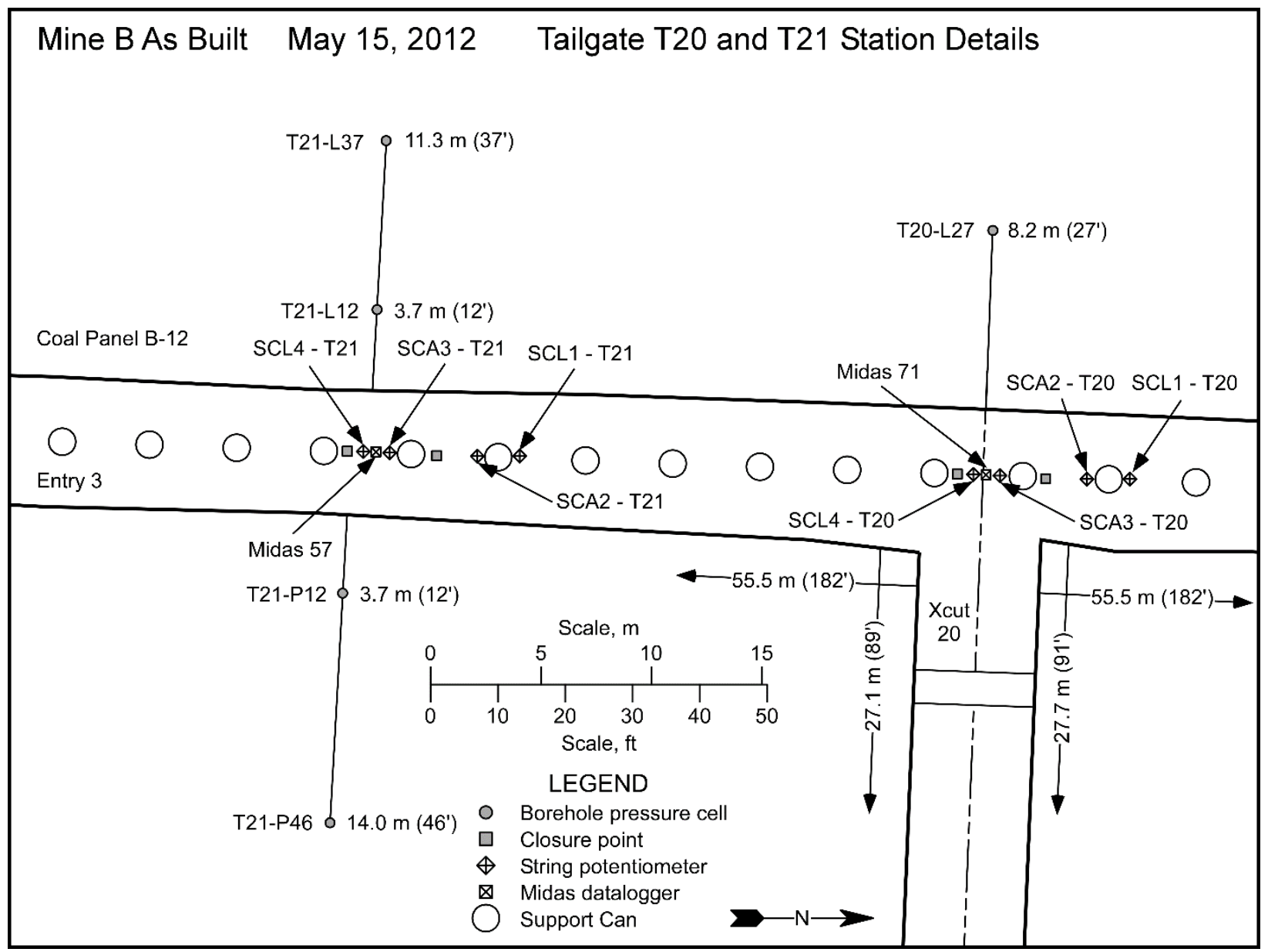

Figure 22. Map showing detail of instruments installed at the T20 and T21 stations in the tailgate of the B-12 panel. 


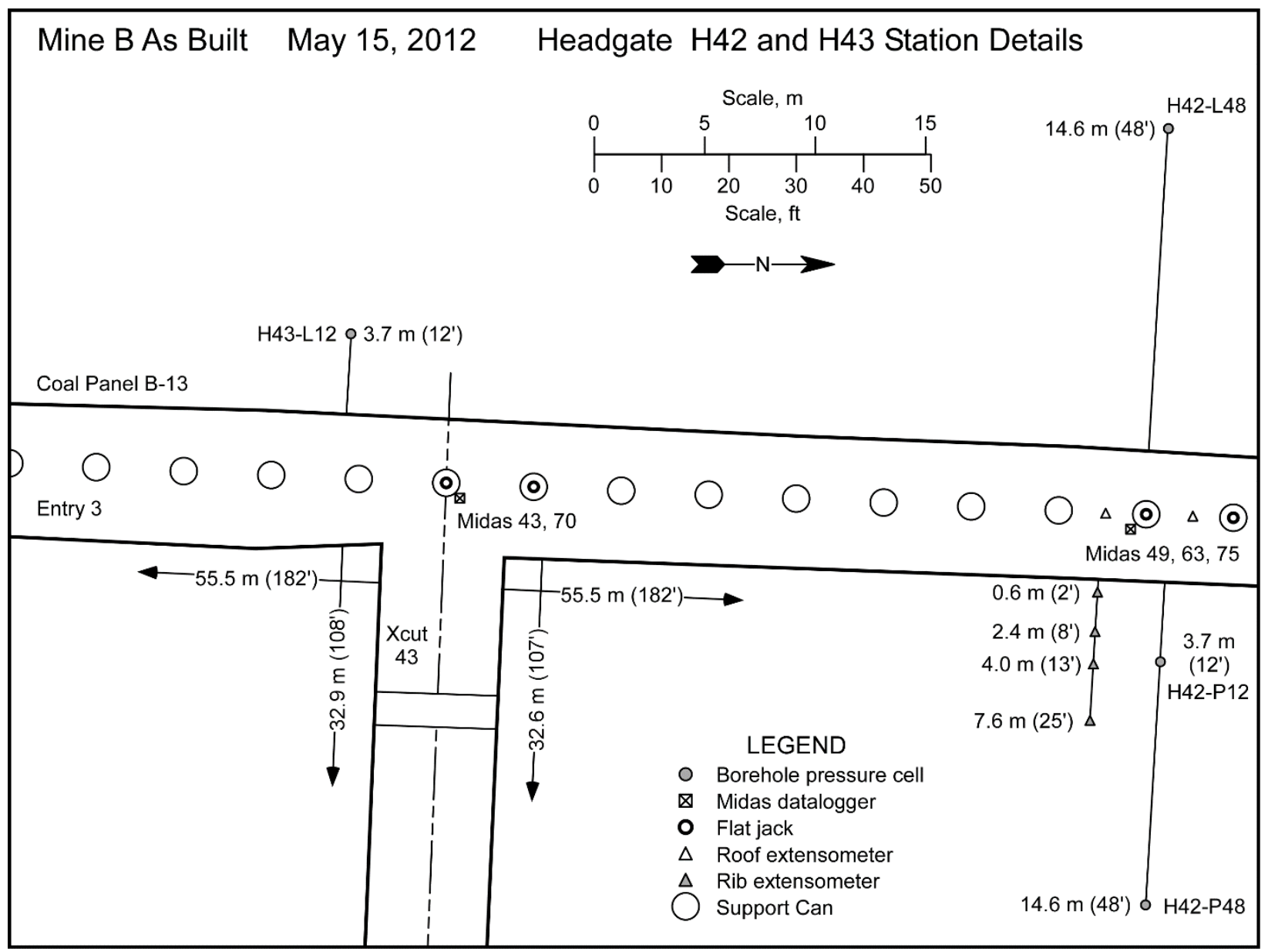

Figure 23. Map showing detail of instruments installed at the $\mathrm{H} 42$ and $\mathrm{H} 43$ stations in the headgate of the B-12 panel. 


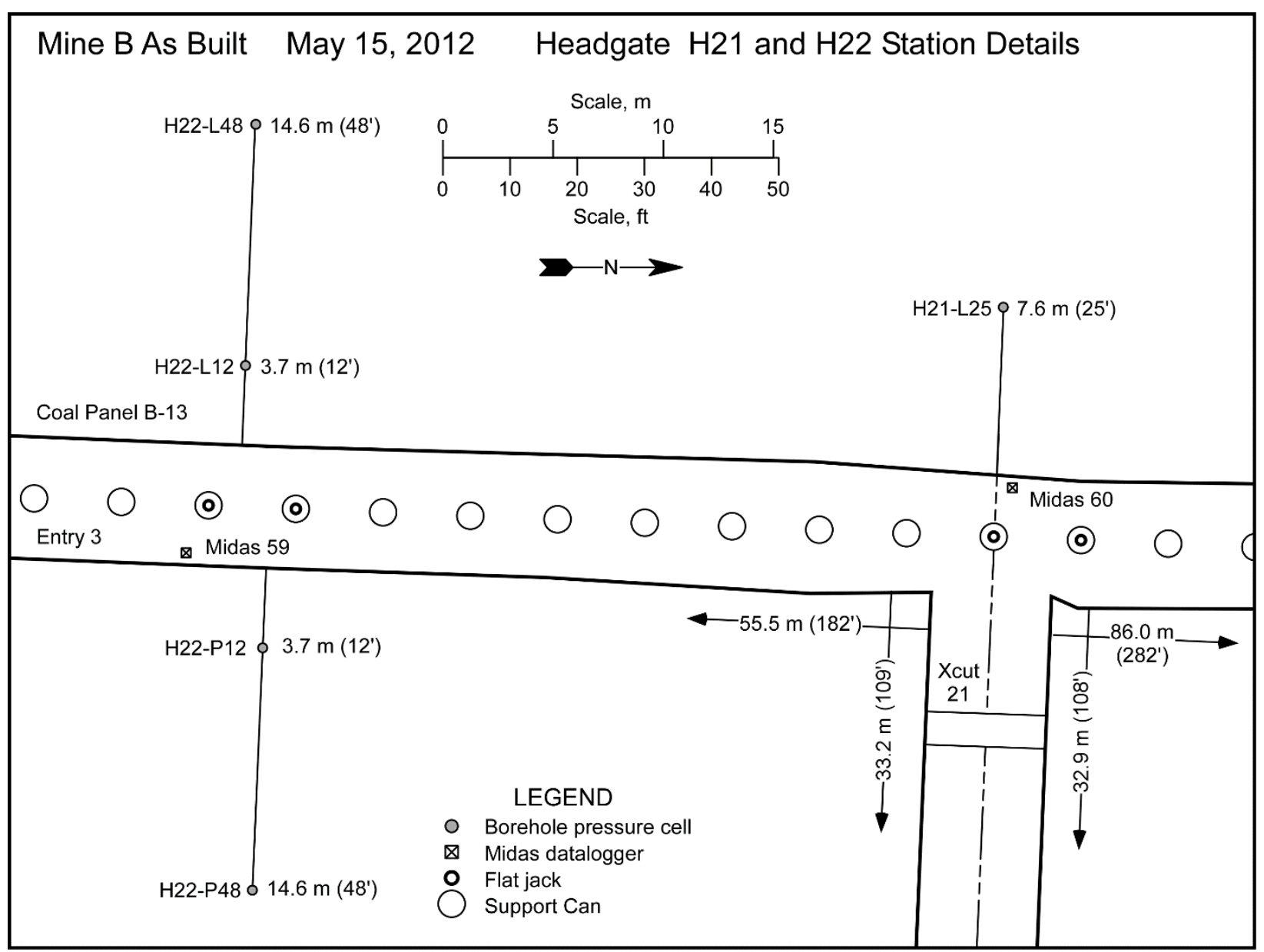

Figure 24. Map showing detail of instruments installed at the $\mathrm{H} 21$ and $\mathrm{H} 22$ stations in the headgate of the B-12 panel.

\section{Measurements}

Measurements from Mine A and Mine B are presented in this section. For Mine B in particular, the measurements presented are those that have relevance to determining the distance ahead of the face at which first arrival of mining-induced abutment stress can be detected. BPC density at any installation site was not high enough to infer much about pillar behavior at Mine B.

\section{Mine A}

\section{Borehole Pressure Cells}

For purposes of this study, particularly for displaying data and convenience in associating face position, the time of midnight on the morning of November 3, 2009, was selected as "zero time." Also, the longwall panel between 1 North and 2 North gate roads is referred to in this report as Panel 1, and Panel 2 is between 2 North and 3 North gate roads. Mining of Panel 1 
longwall had already begun before zero time. Measurements of BPC internal pressure (as sensed at pressure transducers outside of the boreholes) versus time are shown in Appendix A for all four sites. These measurements as shown have already undergone a smoothing technique. That is, each point is an average of the measurement taken at that particular time plus four measurements before it and four measurements after it. Measurements were generally taken hourly. Exceptions to this were at both 2 North instrument sites where the measurement interval became 5 minutes as the Panel 2 face approached each instrument site.

The figures in Appendix A include plots of BPC pressure curves from all four instrumentation sites. A summary of the measurement trends across the measurement cross section shown in the figures of Appendix A is described here. Afterward, cell pressures with distance from the face are plotted for the outby site cells because those sites were located sufficiently far from the startup room to be able to sense first arrival of mining-induced abutment stress.

At the 1 North inby site, the only BPC pressure that peaked and decreased was the cell closest to the panel. In the north pillar, the largest cell pressures were about $5.33 \mathrm{~m}(17.5 \mathrm{ft})$ in from each rib. In the south pillar, the largest cell pressure was in the cell nearest the rib on the panel side. In general, cell pressures in that pillar tapered down with distance from the mined panel, except that the BPC nearest the rib on the side away from the panel appeared to have some concentration of stress above that of the next two cells closer to the panel. BPC pressures in the barrier pillar did not register much pressure increase as a result of mining.

Different trends in cell pressure behavior were present at the 2 North inby site. Here during mining of Panel 1, all but one of the BPCs in the south pillar reached peak pressures and began to decrease. Yielding seemed to occur early, as indicated by cell pressures of BPCs located near the rib, and yielding appears to occur deeper into the rib on the Panel 1 side of the pillar. The same yielding pattern near the rib occurred in the north pillar, but other BPCs' pressures seemed to level off and hold pressures instead of yielding. Installation problems seemed to affect two of the three BPCs in the barrier pillar (next panel). During mining of Panel 2, the cell pressures, shown in Appendix A, showed a general trend of a gradual decrease in cell pressure, followed by an increase in pressure as the face neared. Cells failed as the face was very near or had just passed by the instruments. The exception was BP2, which showed only an increase until monitoring ceased.

At the 1 North outby site, the cell pressures in the barrier pillar were consistent, with the order of largest stress increase corresponding with distance from the mined panel. The stress increases were generally lower than that of any cell in the pillars. The north pillar, which was next to Panel 1, showed more load increase, as expected. The peak cell pressures indicate that the largest stresses were $5.33 \mathrm{~m}(17.5 \mathrm{ft})$ from each rib. In the pillars, all cell pressures peaked, and all but one cell in the middle of the north pillar eventually failed and lost all pressure. However, pressure in that one surviving cell had peaked and had decreased to about 9.65 MPa (1,400 psi). In the pillars, the cells nearest the panel peaked first. The order of occurrence of peak stresses was from right to left in the north pillar (from nearest the panel and progressing away from the panel). In the south pillar, the cell nearest the rib on the panel peaked first, followed by the cell next to it at $5.33 \mathrm{~m}(17.5 \mathrm{ft})$. Then the order continued from the other side of the pillar and progressed inward. This pattern is consistent with the expected qualitative shape of the abutment loading curve in combination with yielding near the ribs.

At the 2 North outby site, all BPCs installed in the south pillar failed at some point during mining of Panel 1. It is likely that seam conditions and trouble with installation compromised the 
integrity of the cells. Borehole pressure cells SP2 and SP3 could not be set to target pressures. However, the trends of the remaining cell pressures do suggest yielding near the ribs and highest stresses in the middle of the pillar. In the north pillar during Panel 1 retreat, the cell nearest the south rib, NP1, failed early, losing all pressure, but loaded and lost pressure repeatedly. NP2 may have been set too high, or at least it had increased in pressure significantly before datalogger monitoring began. That cell took much load and then lost all pressure. NP3 through NP7 survived enough to establish some trends. The cell closest to the north rib, NP7, peaked at about $34.5 \mathrm{MPa}(5,000 \mathrm{psi})$ and then decreased to a residual value of about $27.6 \mathrm{MPa}(4,000 \mathrm{psi})$. Higher stress was found in the middle of the pillar and toward the south side at $11.43 \mathrm{~m}(37.5 \mathrm{ft}$ ) from that rib. In the barrier pillar (Panel 2) during Panel 1 retreat, BP3 at $15.2 \mathrm{~m}(50 \mathrm{ft}$ ) showed some stress increase, but not as much as the cells at $30.5 \mathrm{~m} \mathrm{(100} \mathrm{ft)} \mathrm{and} 38.4 \mathrm{~m}(126 \mathrm{ft})$. The trend is not consistent, and therefore, BP cell pressures cannot be considered reliable for determination of first arrival of abutment stress.

During retreat of Panel 2, all BPCs in the south pillar at the 2 North outby site had already failed. In the north pillar, all cells but NP2 and NP3 continued at high and slightly increasing pressures. However, a seismic event occurred at approximately 11,321.78 hr. All cells in the north pillar but NP7 were depressurized as a result of that event. Cells in the barrier pillar survived the event, but the two deeper cells were compromised just before monitoring ceased. Overall, the trends of all cells in the barrier pillar were similar through mining of both panels, even though BP3 seemed to have lost some initial pressure before datalogger monitoring began.

Figures 25-27 show the cell pressures with distance from the face for BPCs in the barrier pillar, south pillar, and north pillar, respectively, at the 1 North outby instrument station during mining of Panel 1. A negative distance means that the face was inby the line of BPCs. These graphs show that the cells began to take pressure well ahead of passage of the face. The cells in the closest pillar to the panel (north pillar) failed before, at, or soon after passage of the longwall face. The cells in the south pillar experienced increased pressure well after the face had passed, except near the ribs where early yielding took place. All of these cells eventually lost pressure, the hydraulic lines of some probably damaged by passing equipment. BPCs in the barrier pillar saw no significant increase in stress until the face was near. The pressure in these cells continued to rise after passage of the longwall face, but eventually these cells were compromised, again probably by equipment passing by the hydraulic lines.

Figures 28-30 show the cell pressures with distance from the face for BPCs in the south pillar, north pillar, and barrier pillar, respectively, at the 2 North outby instrument station during mining of Panel 1. Similar trends exist with proximity of the pillar to the mined panel. However, in this case, with large pillars, the pillar nearest the mined panel was able to sustain substantial stress well after passage of the longwall face on the interior of the pillar than could the smaller pillars of 1 North. The north pillar also sustained substantial load everywhere except near the ribs. The barrier pillar only saw small increases in stress over time as the longwall passed. At this site, damage from passing equipment was not a problem. Any lapses in data resulted from problems in keeping the datalogger running with sufficient battery power. 


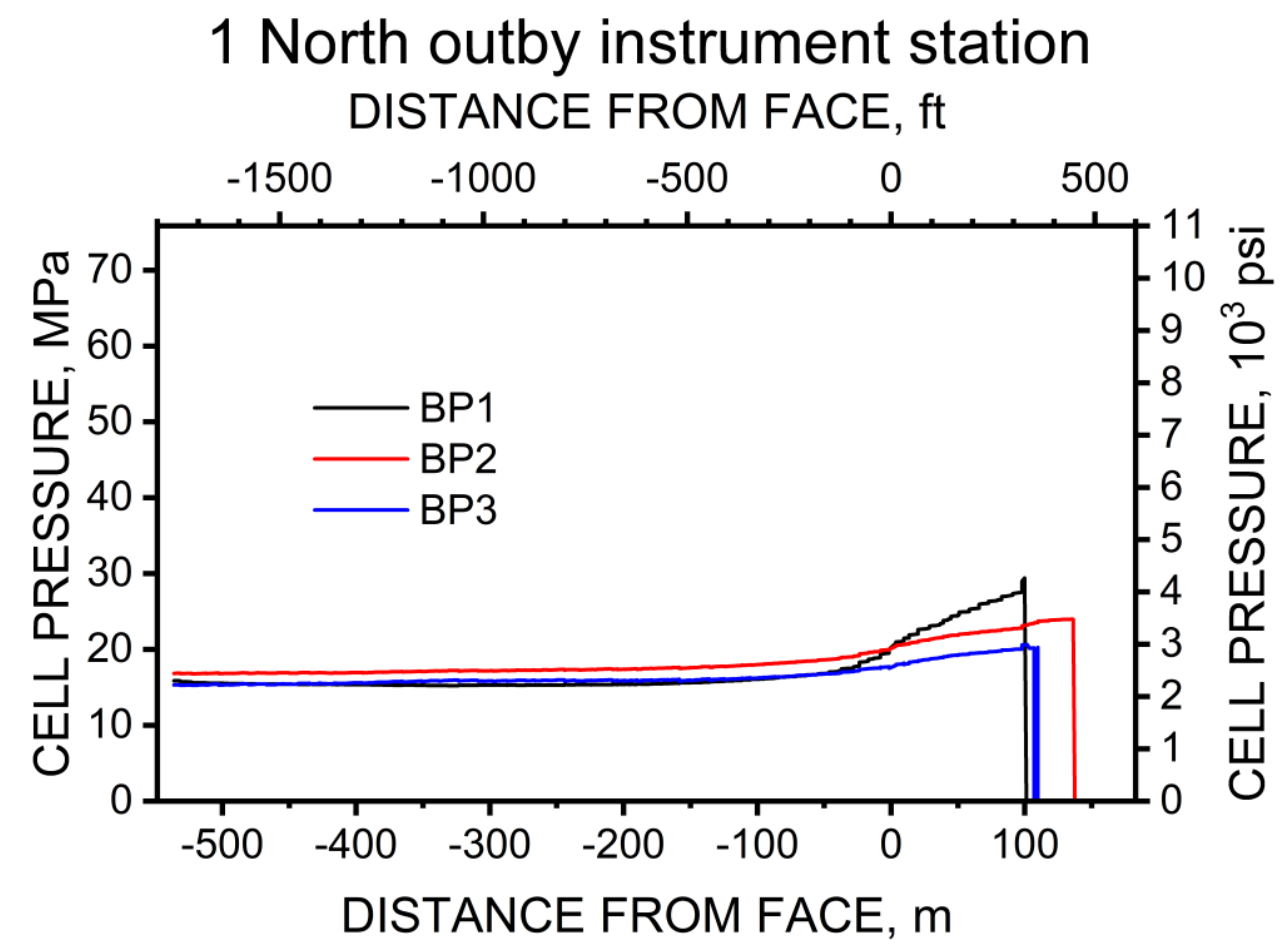

Figure 25. Cell pressure of BPCs in barrier pillar with distance from face at the 1 North outby instrument station.

1 North outby instrument station DISTANCE FROM FACE, $\mathrm{ft}$

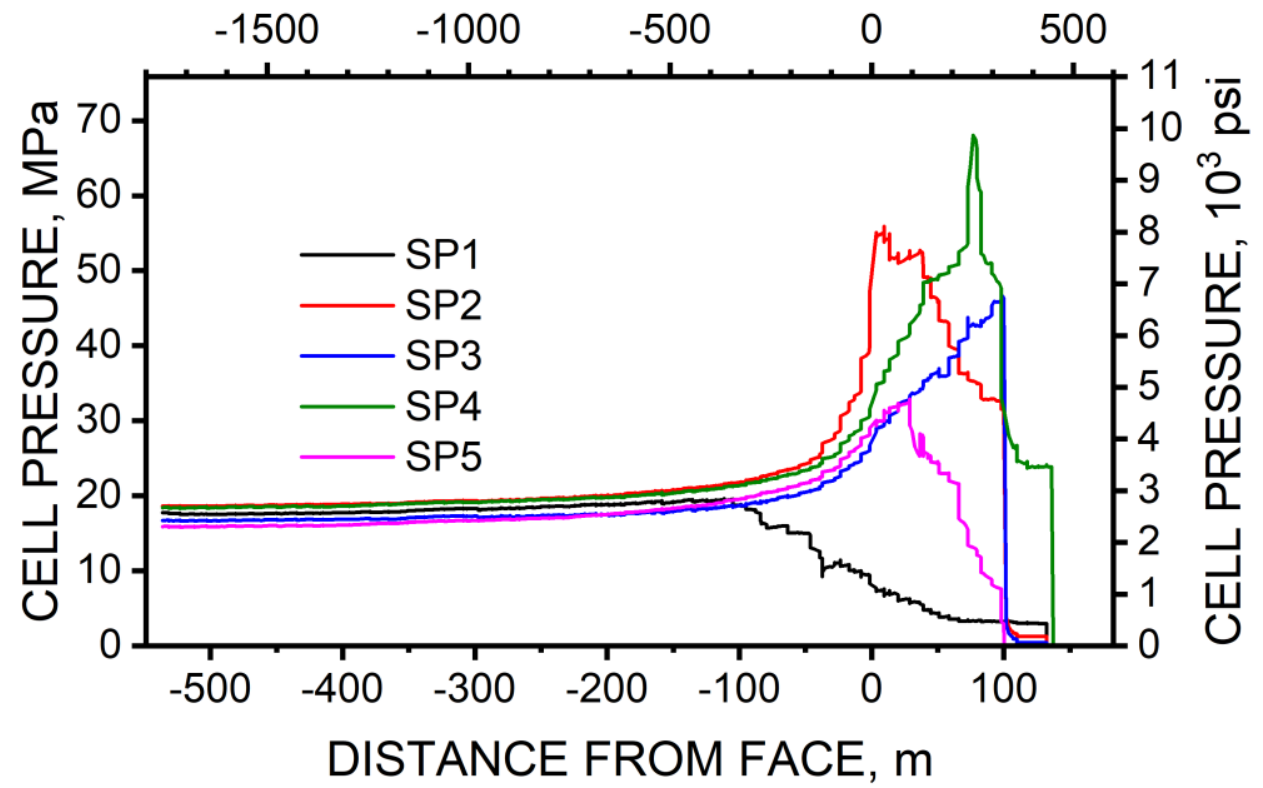

Figure 26. Cell pressure of BPCs in south pillar with distance from face at the 1 North outby instrument station. 


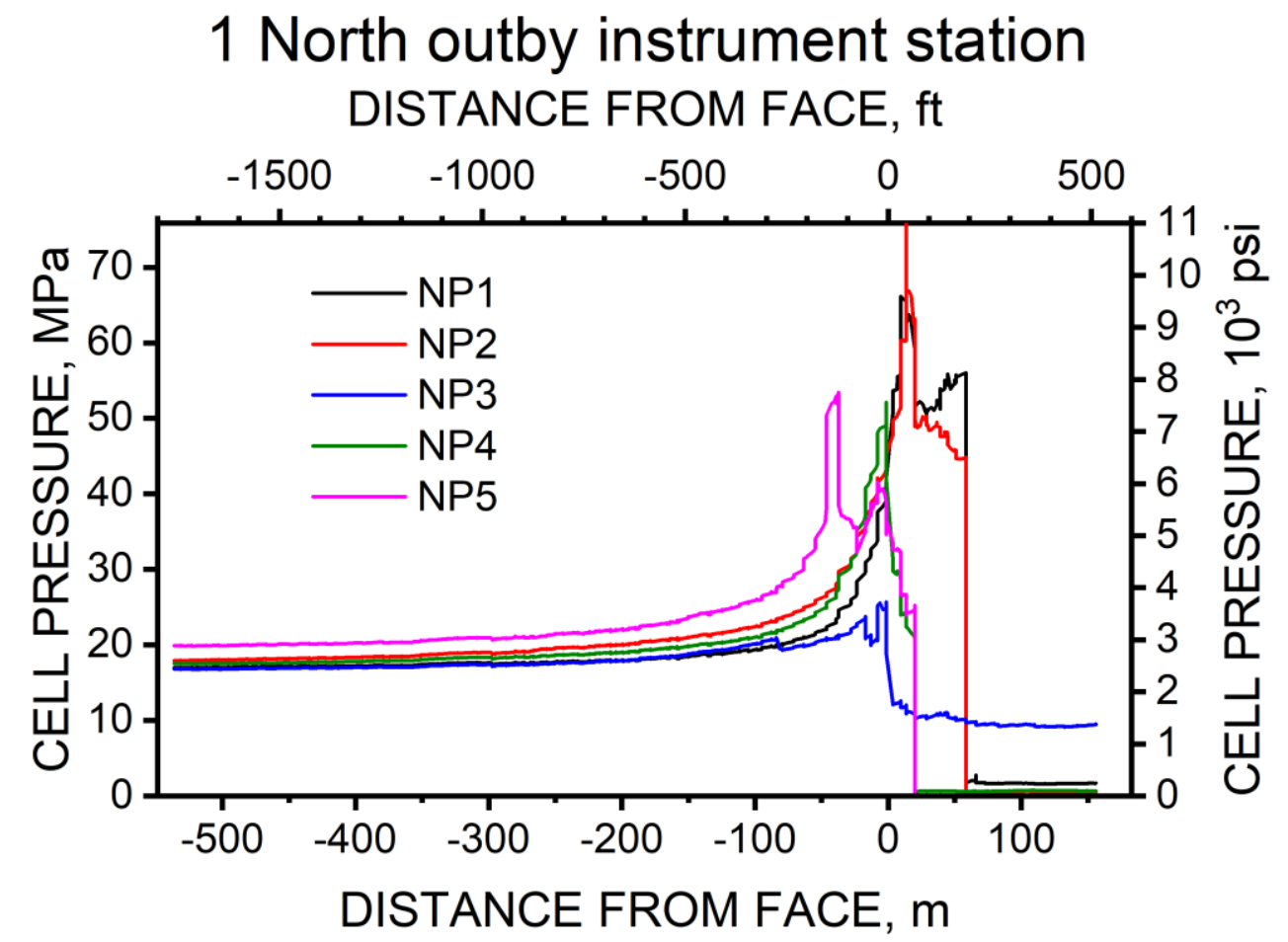

Figure 27. Cell pressure of BPCs in north pillar with distance from face at the 1 North outby instrument station.

2 North outby instrument station DISTANCE FROM FACE, $\mathrm{ft}$

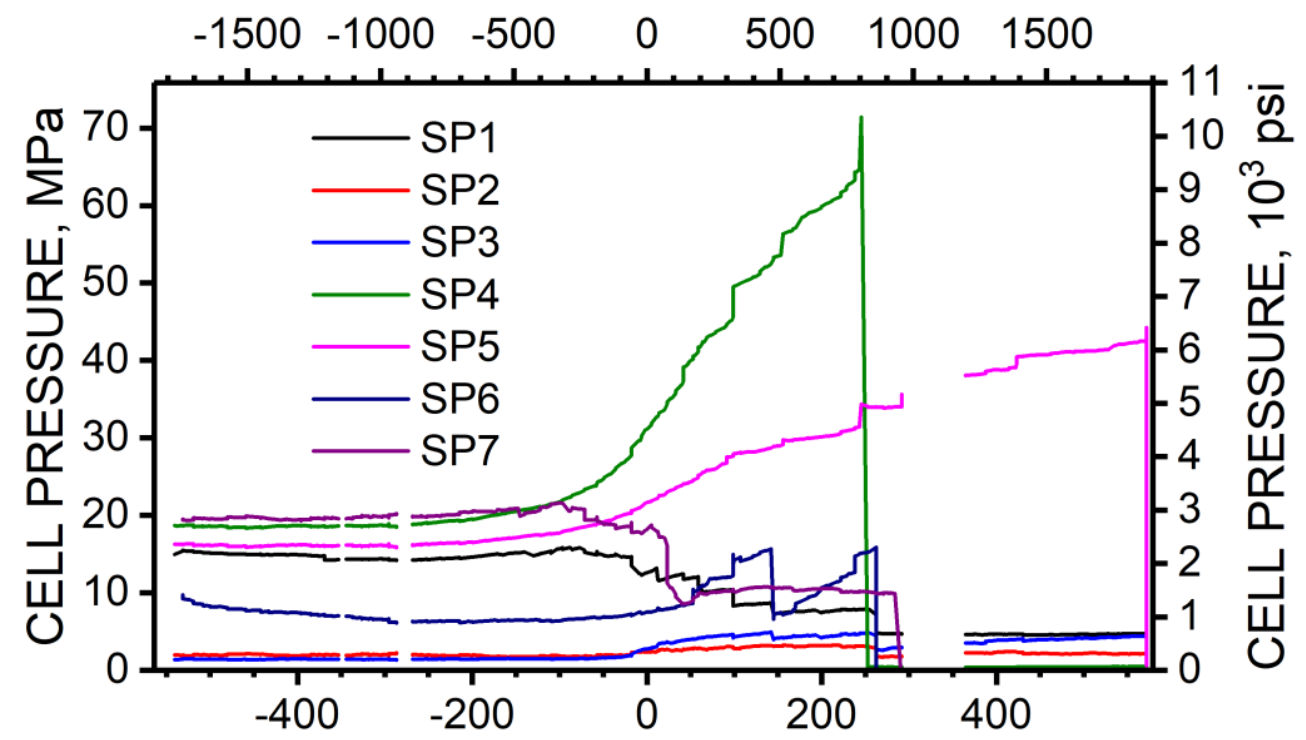

DISTANCE FROM FACE, $m$

Figure 28. Cell pressure of BPCs in south pillar with distance from face at the 2 North outby instrument station. 


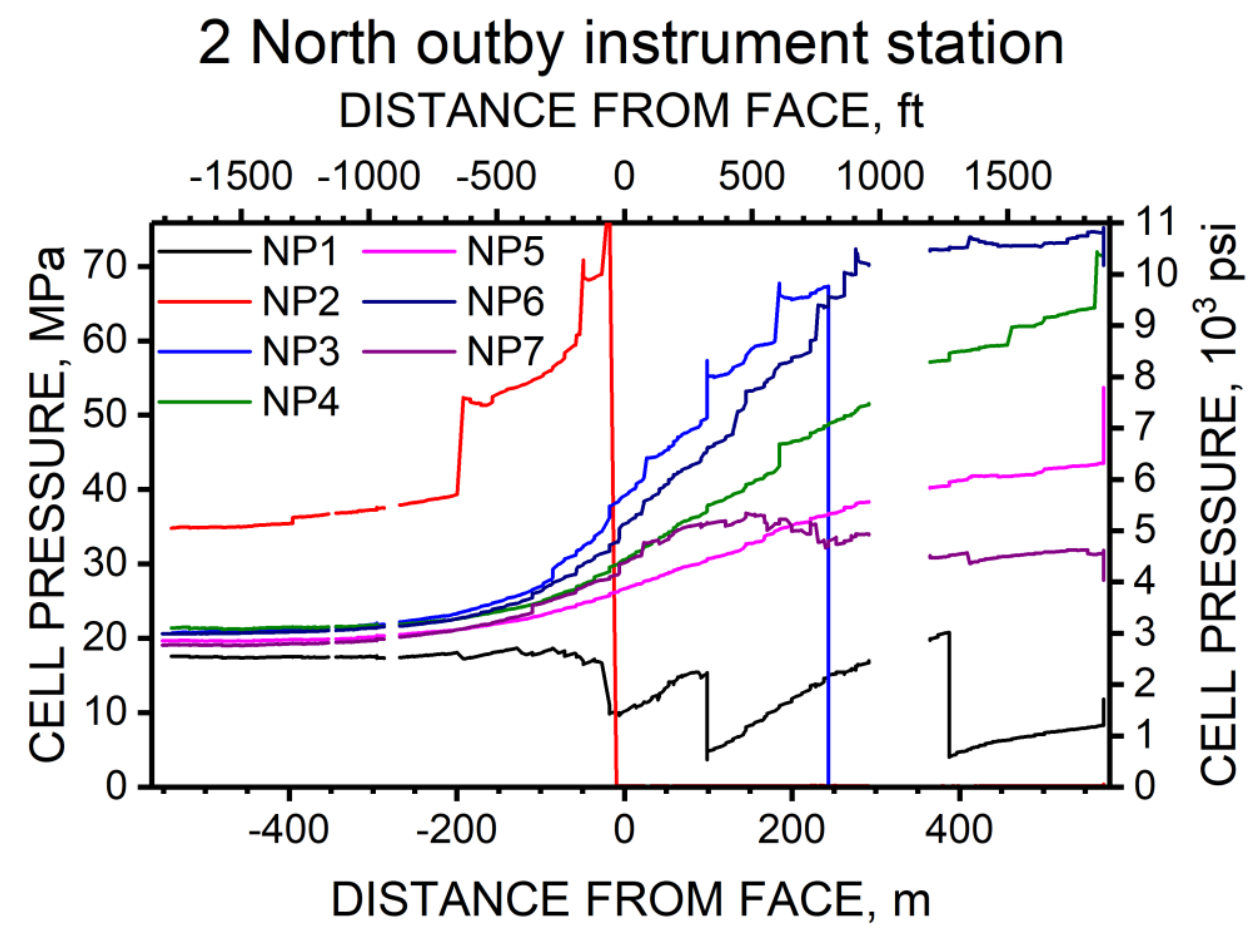

Figure 29. Cell pressure of BPCs in north pillar with distance from face at the 2 North outby instrument station.

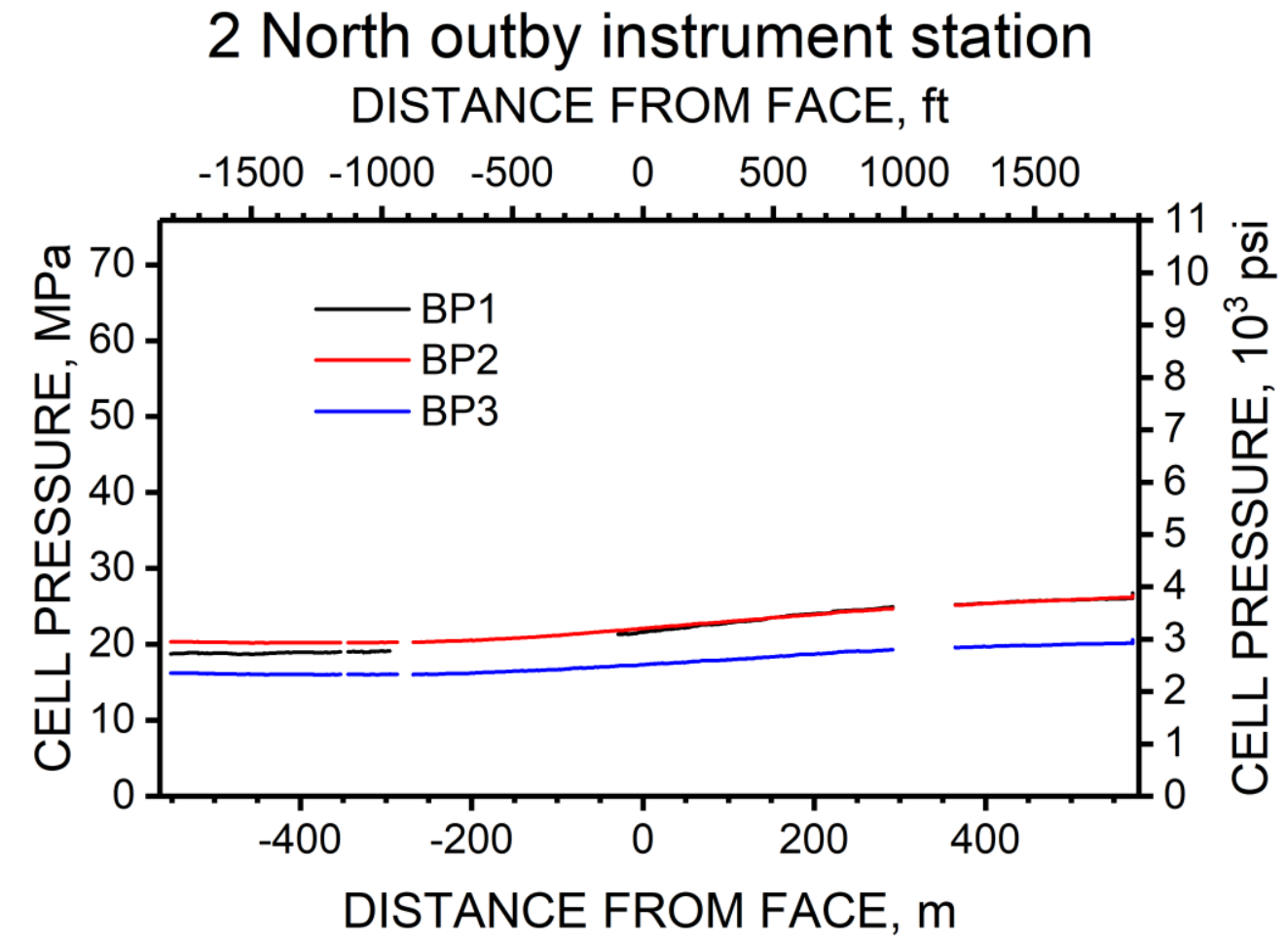

Figure 30. Cell pressure of BPCs in barrier pillar with distance from face at the 2 North outby instrument station. 


\section{Support Cans}

Results of load increase on instrumented support Cans with time are found in Appendix B. Figures 31 and 32 show load increase with distance to the face during mining of Panel 1 for Cans in the intersection of entry 3 and crosscut 10 and in entry 3 between crosscuts 9 and 10 , respectively (see Figure 19), where, again, a negative distance means that the longwall face is inby the site of the Cans. These figures show some load increase as the face approached, but substantial loading after it passed.

All instrumented Cans, both at the intersection of entry 3 and crosscut 10 and in entry 3 at mid-pillar between crosscuts 9 and 10, were installed in time to establish a stable baseline. Afterward, all Cans registered an increase in load resulting from approach of the Panel 1 face. After passing of the face, a steady, but gradual increase in load continued, even during the mining of Panel 2 (see figures in Appendix B). The increase in stress resulting from approach of Panel 2 had not yet registered before a seismic event took place on February 17, 2011. All of the instrumented support Cans were loaded significantly because of that event. Compatible trends were observed in measurements of Can closures during the entire monitoring period. Entry closure amounts, as expected, were greater than the Can closure amounts. Manual closure measurements were consistent with closures measured with string potentiometers. Interestingly, the increase in Can loads resulting from the seismic event was two to three times the increase in Can loads caused by mining up until just before the bump.

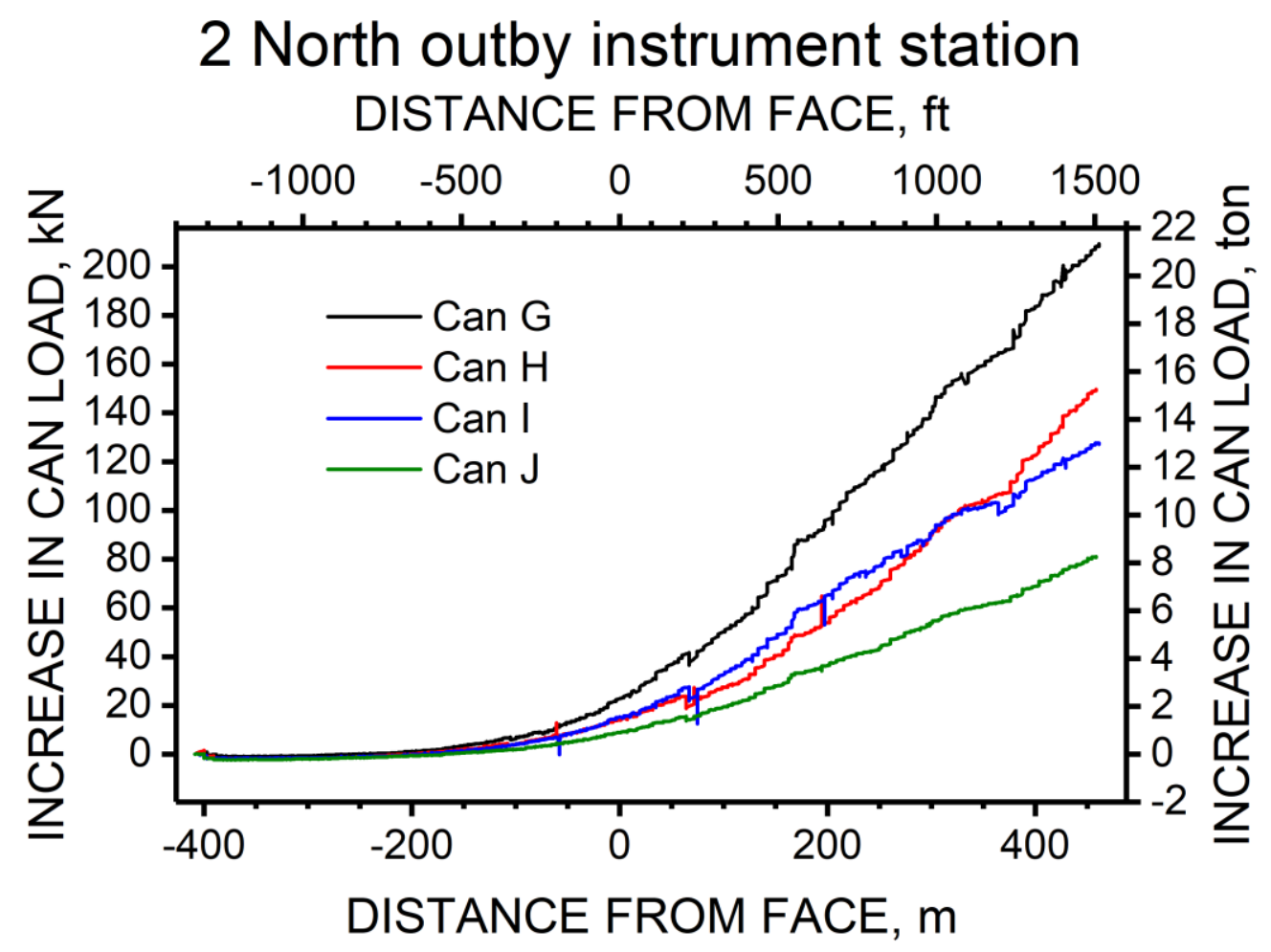

Figure 31. Load increase versus distance from face on support Cans in entry 3 at crosscut 10 in 2 North during mining of Panel 1. 


\section{North outby instrument station DISTANCE FROM FACE, $\mathrm{ft}$}

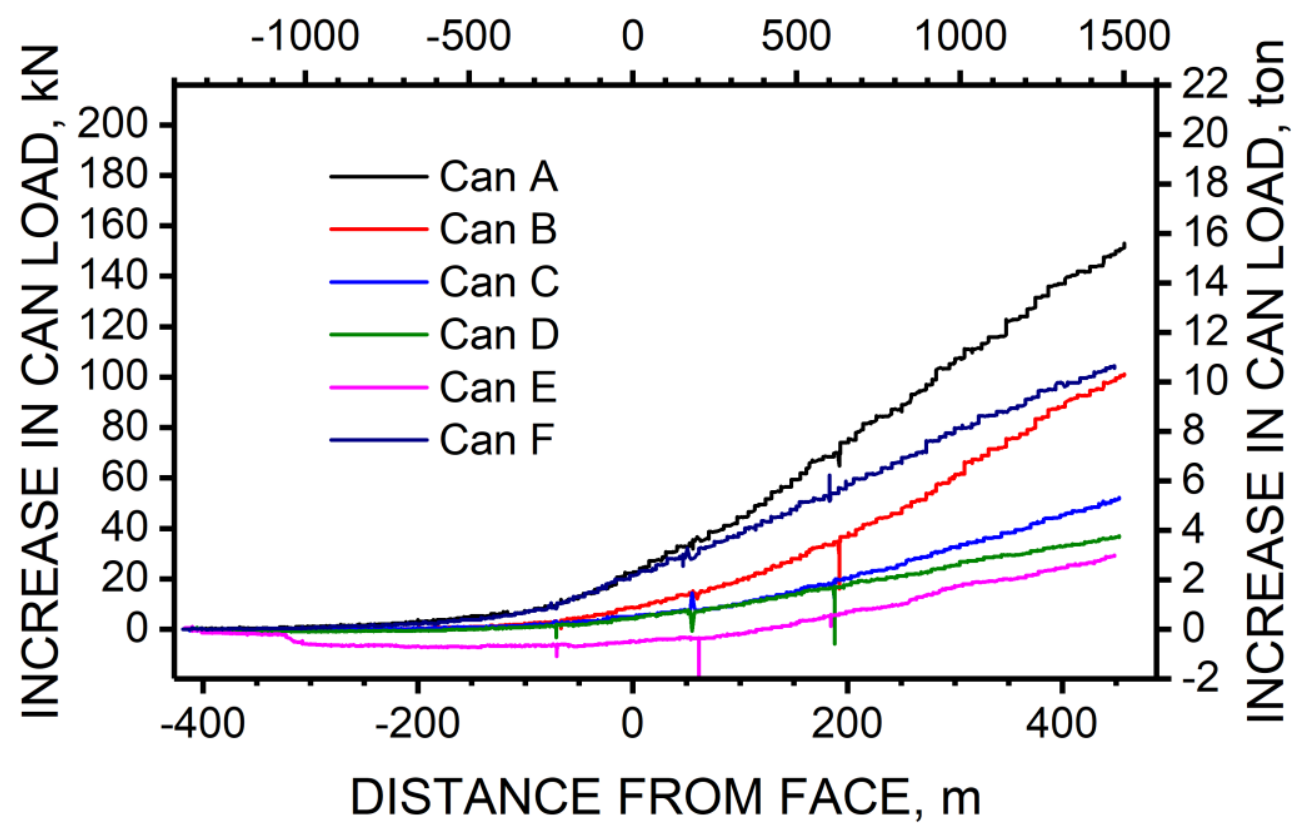

Figure 32. Load increase versus distance from face on support Cans in entry 3 between crosscuts 9 and 10 in 2 North during mining of Panel 1.

\section{Entry Closure and Roof Sag}

Graphs of measurements of closure and roof sag are found in Appendix C. The appendix points out some trends or lack of them. However, in general, these measurements suggest that either the instrument installations and measurements were problematic or that roof and floor stratigraphy was generally not constant but quite variable, especially in the 2 North gate roads. The latter explanation seems to be more likely because some measurements in 1 North were consistent. The inconsistency registered by these instruments are also likely caused by deteriorating ground conditions because of proximity to intersecting faults, shown in Figure 3.

\section{Ground Condition Surveys}

Results of ground condition surveys were characterized through three phases of mining progress: development, longwall approach, and side gob development. The approach of the longwall face provided ever-increasing loading of pillars. Conditions stabilized quickly after development and remained static for many months prior to startup of longwall panel mining.

\section{North Gate Roads}

Conditions began changing as the longwall approached, as can be clearly seen in plots of deterioration against distance to the longwall face. Such plots can be compared to model results. A plot typical of the middle entry in the 1 North gate roads at a specific location between crosscuts 8 and 9 is presented in Figure 33. The effect of longwall loading was evident about 305 $\mathrm{m}(1,000 \mathrm{ft})$ inby as first roof and then rib deteriorated. The floor remained intact. This pattern 
was found to be typical of about $80 \%$ of the 1 North gate roads. Ground response began to vary by entry as the longwall passed and the side gob became increasingly important.

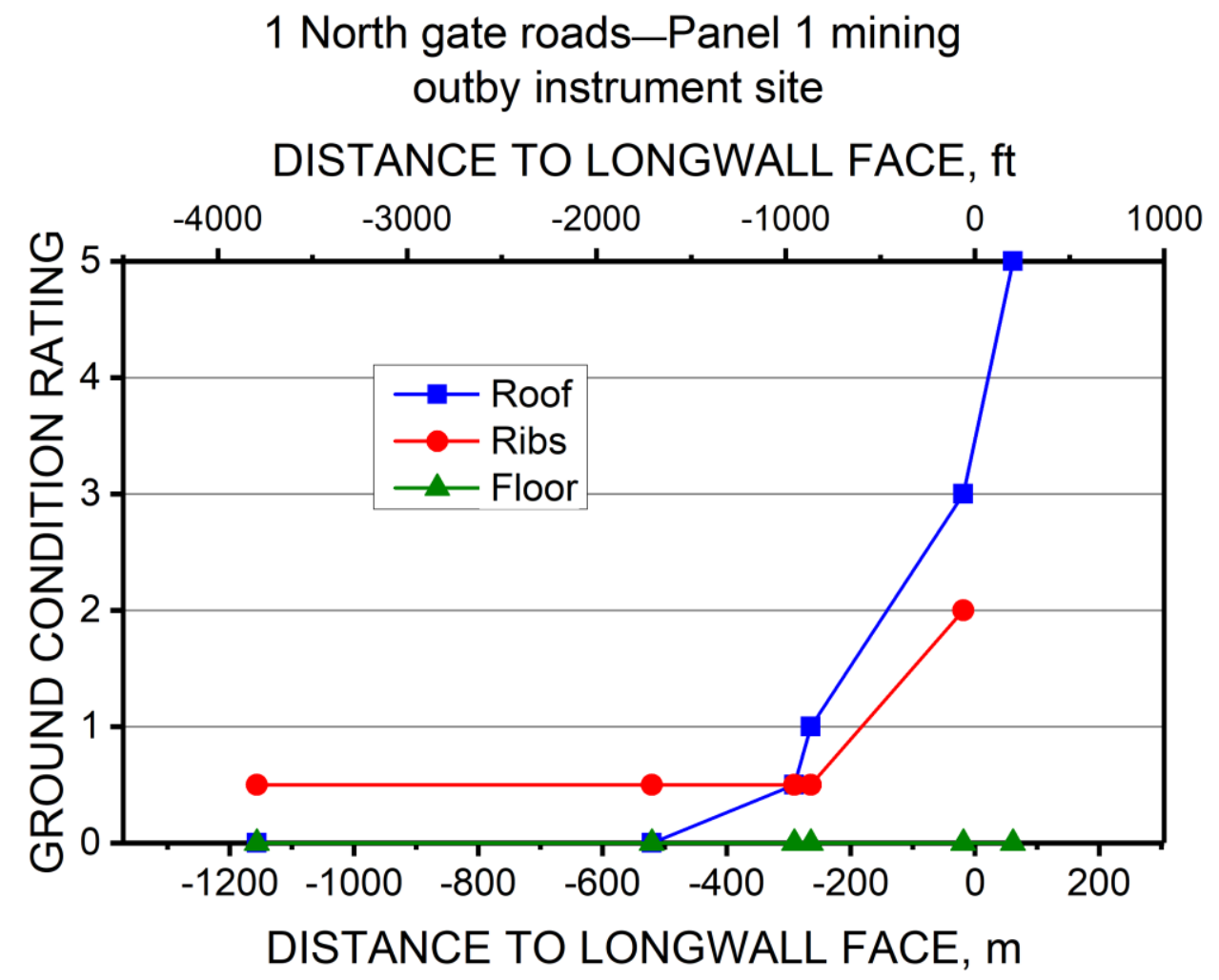

Figure 33. Deterioration ratings between crosscuts 8 and 9 , entry 2 , in 1 North, an instrumented location relative to the longwall face.

Notes on the mechanism of roof deterioration were taken during entry surveys as well. A consistent pattern of roof deterioration was observed in the middle entry with approach and passage of the longwall face. Roof sag became pronounced with face advance, developing from isolated to continuous. Sag was accompanied by further opening of roof joints and creation of deep tension cracks oriented parallel to the gate road to subperpendicular to jointing.

Rubblization of the roof was focused between the two centermost roof bolts, creating an obvious bulge in the mesh. This bulge eventually split, spilling rubble onto the floor. Mesh bagging and failure was consistent rather than local, appearing as a "zipper-like" failure along the length of the entry. Roof straps were kinked at their centers as if they had been laterally compressed. Further caving and rib degradation closed the entry entirely, typically within $61.0 \mathrm{~m}(200 \mathrm{ft})$ inby of the face line.

The remaining $20 \%$ of the gate road deteriorated in a markedly different fashion. These areas, defined as "anomalous" zones, typically span several pillars. These areas usually departed from the norm in both the degree and kind of deterioration. For instance, one such zone in the 1 North gate road suffered very minor, but noticeable, floor heave. This contrasted strongly with the majority of experience where no noticeable floor heave was observed (e.g. Figure 33). The nature of these zones is being investigated but appears to be influenced by local geologic features. They do not correlate with depth of overburden. Also noteworthy may be the observations that in both the inby and outby anomalous zones there were discrete (no greater 
than $3 \mathrm{~m}$ [10 ft] in length) areas of unusual rib failure - it was deeper, more abrupt, and had mylonite (red powder) [Australian Coal Association Research Program 2014] on some of the fracture planes.

\section{North Gate Roads}

The 2 North gate roads, which were to serve as a future tailgate as well as the headgate for the first panel, were developed with significantly larger pillars to withstand the additional load resulting from mining both adjacent panels. The increase in pillar capacity might be expected to improve gate road conditions. This was evident in index readings of entry 2 between crosscuts 11 and 12 (see Figure 34) as the face passed, which reached a maximum value of two (as opposed to three in Figure 33). However, deterioration unexpectedly was absent altogether in the roof although appearing in the floor. Heave occurred in the middle of the entry with passing of the longwall. It occurred in a manner similar to buckling failure as illustrated in Figure 35. This behavior was typical of about $80 \%$ of the 2 North gate roads. Such pillar foundation failure is widespread in some regions [Gadde and Peng 2009].

\section{North gate roads-Panel 1 mining outby instrument site}

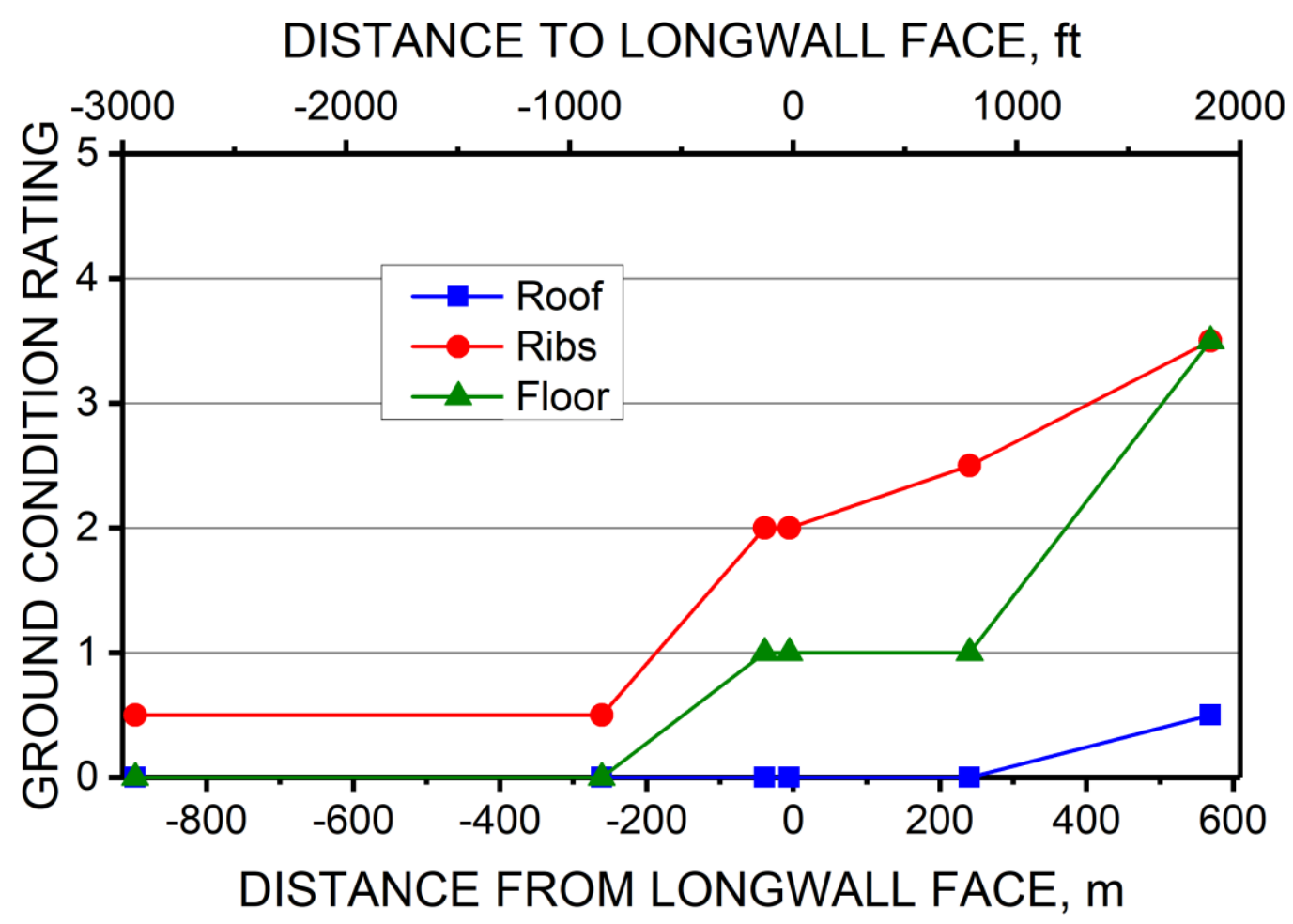

Figure 34. Changing index ratings in the roof, ribs, and floor in the 2 North gate roads during Panel 1 mining in entry 2 between crosscuts 11 and 12 . 


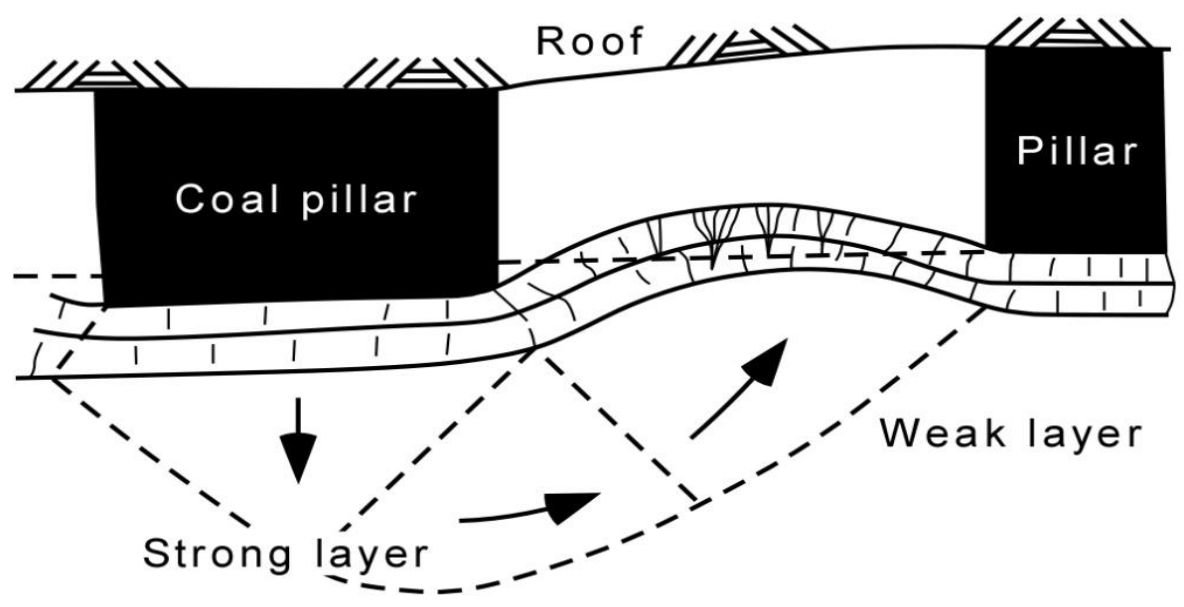

Figure 35. Buckling failure of the type observed in the 2 North gate road (after Rockaway and Stephenson [1979]).

Anomalous conditions were observed in two segments of the 2 North Gate roads, each several crosscuts in length, soon after passing of the longwall face. Deterioration in these areas was further advanced and included the roof. Figure 36 is an example of one of these zones in the vicinity of crosscut 24 in entry 2 . These segments appeared to be associated with particular faults, but not all intersecting faults produced anomalous zones. This association was not evident in the first set of gate roads (1 North). It is possible that another structure is indicated, especially with higher baseline ratings, as suggested in Appendix D.

2 North gate roads, entry 2 , panel 1 mininganomalous zone from crosscut 24 to crosscut 28

DISTANCE TO LONGWALL FACE, $\mathrm{ft}$

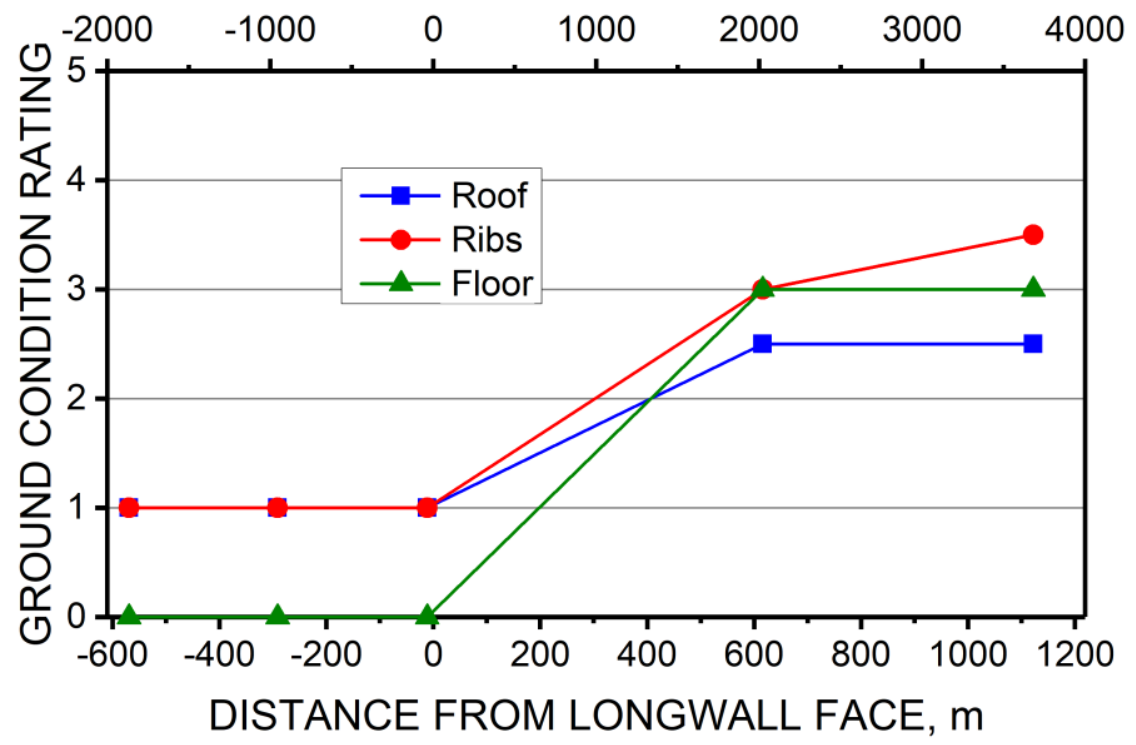

Figure 36. The varying index ratings in the roof, ribs, and floor in an anomalous zone near crosscut 24 in entry 2 of the 2 North gate roads during Panel 1 mining. 


\section{Summary of Survey Results_Floor Heave}

The regularity of the occurrence of floor heave differed between the two sets of gate roads. In the 1 North gate roads, floor heave was an unusual event and was the only qualifying characteristic of the 1 North "anomalous zone." This heave occurred prior to longwall startup, while the 2 North gate roads were still being developed. The floor had been rehabilitated prior to the beginning of ground condition surveys, and as such, was given an initial baseline rating of 0 throughout the length of 1 North gate road. This baseline rating did not change during the course of observation, indicating that the initial reported heave was not linked to stresses induced by the longwall.

In the 2 North gate road, by contrast, normal (i.e., not falling within the boundaries of an anomalous zone) floor heave was observed in advance of the longwall face by about 1 to 2

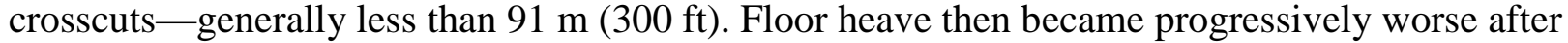
the passage of the longwall. In these areas, floor heave was accompanied by very minimal roof deterioration. The floor and ribs appeared to be the weakest links of the system. In anomalous zones, floor heave began at approximately the same location relative to longwall progression as areas where deterioration was more typical. However, in areas that deteriorated anomalously, the deterioration progressed more rapidly and was accompanied by deteriorating roof conditions as well. Details of these changes are provided in Appendix D.

\section{Mine B}

\section{Borehole Pressure Cells}

The results of BPC measurements unfortunately were less than ideal, but every attempt was made to extract some useful information from the data. Of the 19 BPCs that were installed, as described in Appendix E, seven are candidates to be used for determining the distance ahead of the face where first arrival of mining-induced abutment stress can be detected. These are P46, $\mathrm{P} 12$, L12, and L37 at the T21 site and P48, P12, and L12 at the $\mathrm{H} 22$ site. To remain a candidate for determining the distance at which mining-induced abutment stress is first detected, an initial trend, which may be slightly downward, must be followed by an upward departure from that trend. Also, the amount of cell pressure must be near the expected in situ stress level for that site.

Figure 37 shows BPC cell pressures that have been smoothed using a 9-point running average with distance to the face along the entry at the T21 site. After solving the problems of hydraulic leaks at connections and repressurizing the cells, all curves but one met the criteria for continued candidacy. The curve of the cell in the panel at $11.3 \mathrm{~m}(37 \mathrm{ft})$ does not show a departure from the initial trend, and therefore, it was eliminated from further candidacy. The

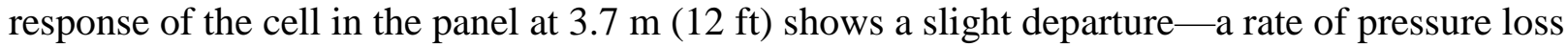
that is less than that of the initial trend. Therefore, its indication of first arrival of abutment stress may not be very clear, but it still remains a candidate. 


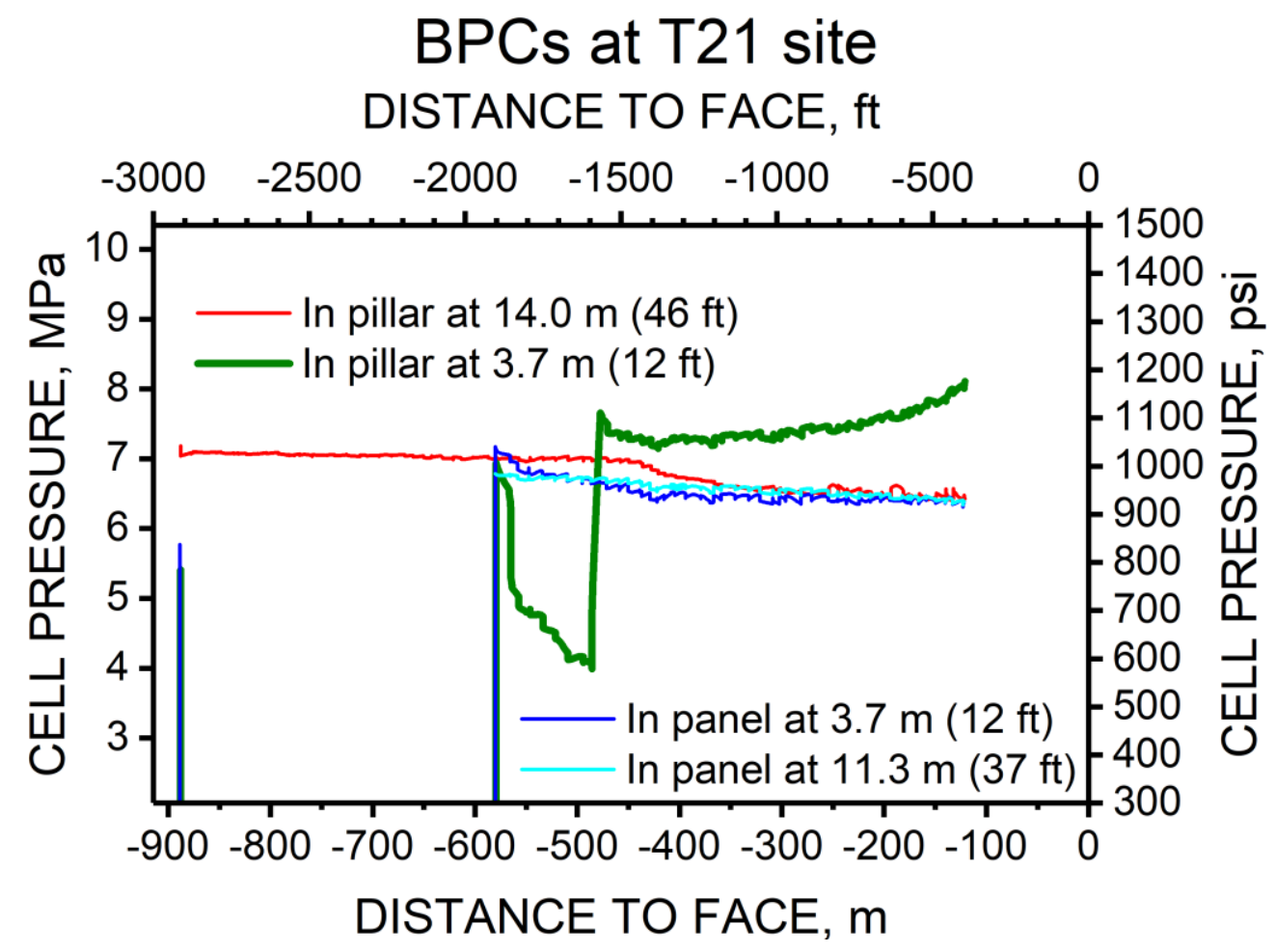

Figure 37. BPC pressure versus distance to the face of instruments at the T21 site in entry 3 of the B-12 panel tailgate at Mine B.

Figure 38 shows BPC pressures at the $\mathrm{H} 22$ site using the 9-point rolling average smoothing technique for candidate instruments with distance to the face. All of these curves meet the criteria to remain candidates for determining first arrival of abutment stress.

The density of BPCs at each site was not enough to use the trends to make any conclusions about pillar behavior, unlike the BPCs at Mine A. Therefore, their results are only used for determining first arrival and are not used hereafter to determine anything about pillar behavior. 


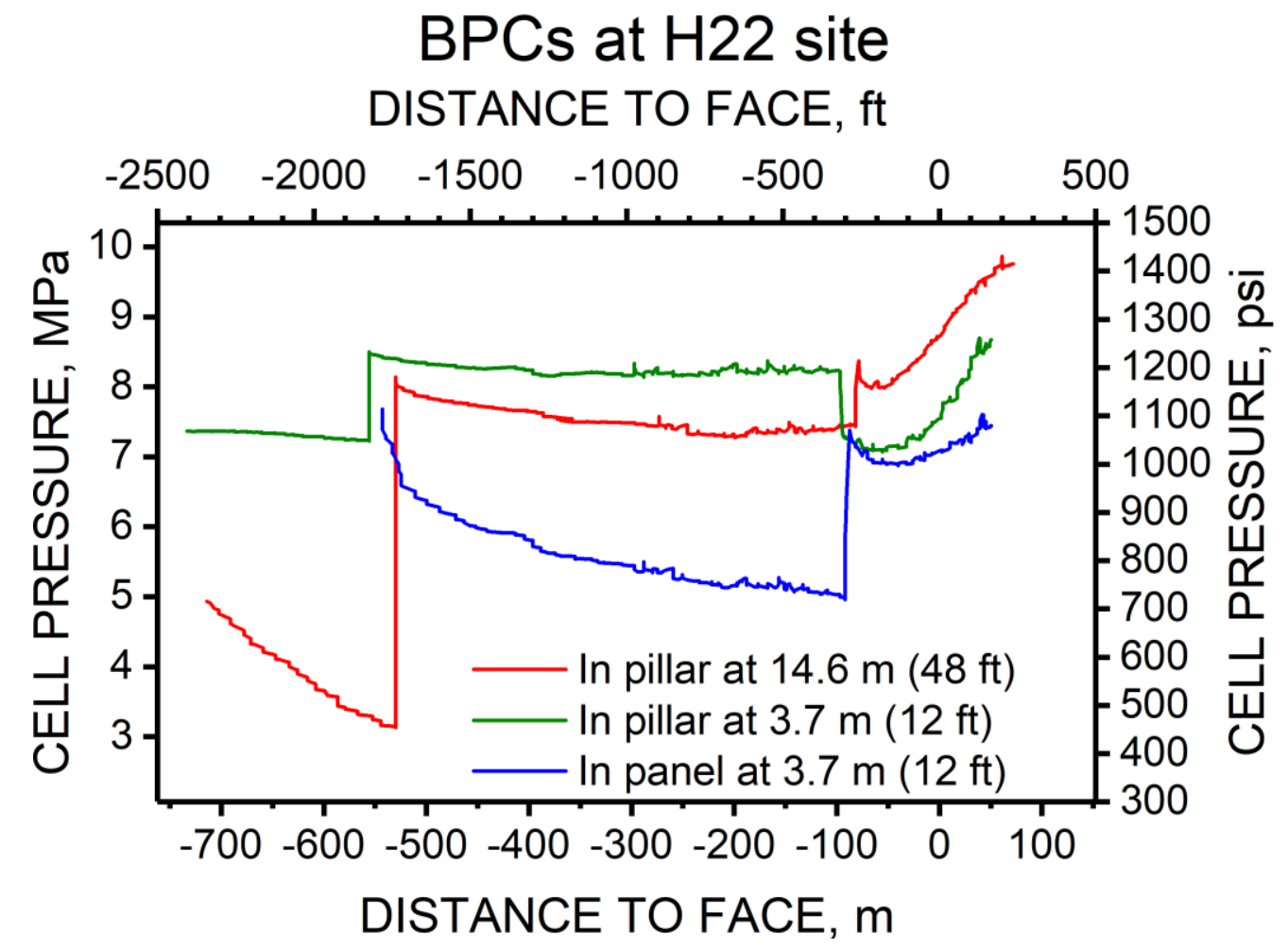

Figure 38. BPC pressure versus distance to the face of instruments at the $\mathrm{H} 22$ site in entry 3 of the B-12 panel headgate at Mine B.

\section{Support Can Loads}

Appendix F describes the support Can loads that were measured in the B-12 headgate \#3 entry. Only the outby Can at the $\mathrm{H} 21$ site is a candidate for determining the distance to the face at detection of first arrival of mining-induced abutment stress. Figure 39 shows measurements of load applied to that Can with distance to the B-12 panel face. The curve was very noisy, but it was smoothed in this figure using the 9-point rolling average. Although the sensitivity for measurement here was less than at Mine A, using the same threshold as that at Mine A is desirable for consistency in determining first arrival of abutment stress. However, the noise level was well above that threshold. Even so, it appears that a first arrival would most likely be welldefined by the sudden increase of load on the Can when the face was approximately $525 \mathrm{~m}$ $(1,723 \mathrm{ft})$ before the Can. 


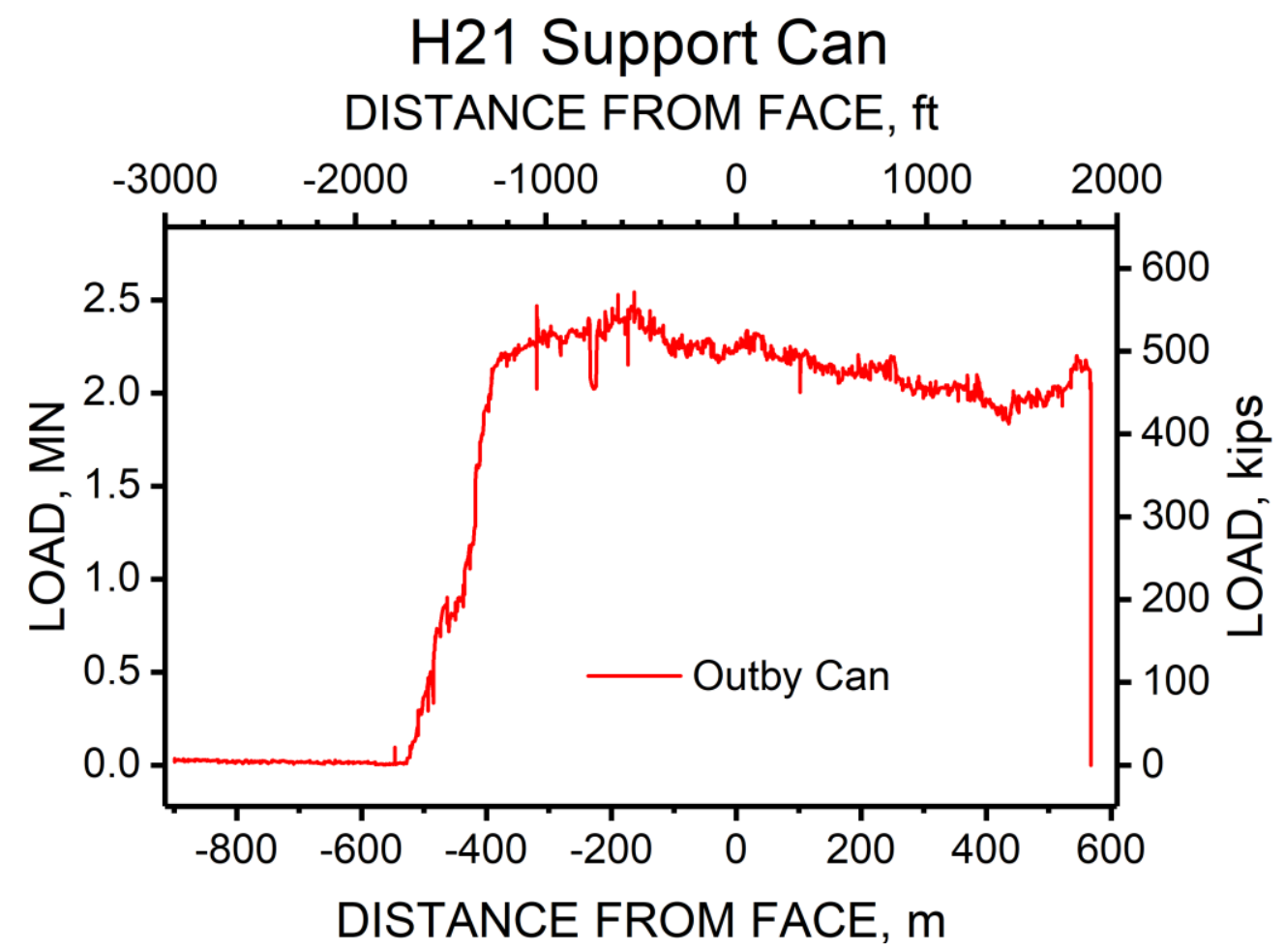

Figure 39. Outby support Can load with distance to the face in entry 3 at the $\mathrm{H} 21$ site in the B-12 panel headgate at Mine B.

\section{Entry and Support Can Closures}

Appendix G describes the details of these measurements in entry \#3 of the B-12 tailgate. The only candidates for determining the distance from the face of first arrival of mining-induced abutment stress are the outby entry and roof-to-mid-height of Can closures at T34 and the inby entry and roof-to-mid-height of Can closures at T20. Figure 40 shows these measurement curves plotted with distance from the face along the entry. All four curves show an initial constant closure rate before the rate of closure increased as a result of mining of the B-12 panel. The point of departure is less certain with the measurements at the T20 site because the amount of closure is much smaller, and thus, the sensitivity to first arrival of abutment stress is reduced. 


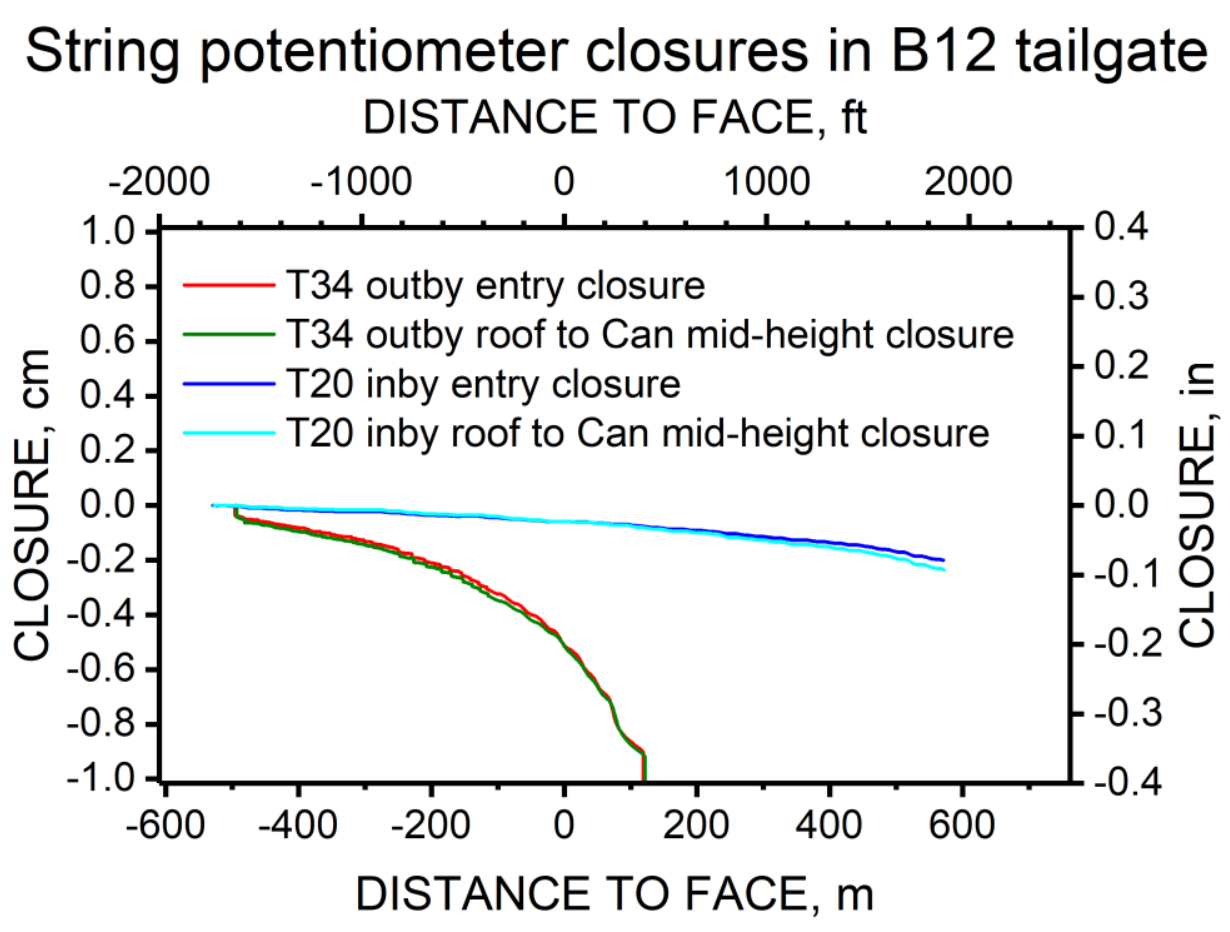

Figure 40. Entry and roof-to-Can midheight closures versus distance to face at the T34 and T20 sites in the B-12 tailgate.

\section{Other Measurements}

Appendix H contains measurements such as ground condition surveys, roof sag, and rib displacement. Ground conditions surveys were not conducted with sufficient frequency to be able to detect any first arrival of mining-induced abutment stress. The roof and rib extensometer measurements were conducted at the $\mathrm{H} 42$ site, which was too close to the startup room to be useful in detecting first arrival of abutment stress because the full abutment stress distance had not yet extended to full distance. The measurements are shown in Appendix $\mathrm{H}$ for completeness of the measurement record.

\section{Distance to First Detection of Mining-induced Abutment Stress}

The measurements already presented in this report-BPC pressures, support Can loads, support Can closure, entry closure, roof sag, rib dilation, and deteriorating ground conditionsshow changes with time. Such measurements can be indicative of the arrival of increase of abutment stress resulting from mining of longwall panels. The distance from a longwall panel at approximately its midlength at which time mining-induced stress increase can be detected is called the load transfer distance, as will be illustrated in the next section. The preceding cases show possibility to detect some indication of load transfer distance, although measurements with each set of instruments likely have different sensitivities in detecting load transfer distance. To be clear, we cannot directly measure load transfer distance because our measurements are not located at the side of the panel. However, by measuring the distance ahead of the face where such stress, displacement, or load increases are detected, such distances might be converted to 
equivalent side load transfer distance by using an appropriate numerical model that calculates the location of such stress increases to the side and ahead of the face. Thus, there is a ratio of distances to the threshold contour of mining-induced stress increase. Such conversion will not be demonstrated in this report but will be shown by Larson et al. in Ground Stress in Mining Part 2 [NIOSH 2020].

The ratio between the two distances allows calculation of the equivalent load transfer distance. Larson and Whyatt [2012] demonstrated the technique with similar measurements when calibrating the rock mass stiffness of a panel model using the displacement discontinuity modeling computer program LaModel. Larson and Whyatt [2013] also found that the technique could be used for calibrating the rock mass stiffness using another displacement discontinuity modeling computer program Mulsim, which may be a more appropriate tool when load transfer distances are significantly greater than those calculated with the empirical Peng and Chiang equation (described in the section that follows). A review of the concept of measuring load transfer distance follows in the next section. Thereafter, the suitability of each type of instrument to detect load transfer distance is discussed and such determinations are made, if appropriate.

\section{Review of Concept}

Load transfer distance is a measure of the extent that overpanel weight is transferred to the abutment as a result of panel mining. It is important because it is used to calibrate the stiffness or stiffnesses of various members of the geologic column in numerical models. It is measured to the side of the panel, at far enough distance from the panel ends that end effects are negligible. The concept was advanced by Peng and Chiang [1984], who made several determinations of load transfer distance in eastern U.S. coal mines with measurements, as shown in Figure 41, and was represented with the empirical Equation 2, which is repeated here as

$$
L T D=9.3 \sqrt{H}
$$

where $L T D=$ load transfer distance in $\mathrm{ft}$, and

$H=$ height of the overburden in $\mathrm{ft}$.

In a longwall mine layout, it is practical to measure first arrival of the abutment load ahead of the face in the pillars, the panel, or the next panel or barrier pillar. The distance to gob must then be converted to an equivalent side load transfer distance with the use of a model. That conversion is beyond the scope of this report, but it is described and executed by Larson et al. in Ground Stress in Mining Part 2 [NIOSH 2020].

The sensitivity to load transfer distance for each kind of instrument is unique for a specific set of conditions. Larson and Whyatt [2012] established a threshold of cell pressure increase for the borehole pressure cell to indicate first arrival of abutment load, and hence, determine equivalent load transfer distance. To determine the threshold, two guiding principles were used in the form of questions: (1) What can the instrument and datalogger (or measuring method) consistently sense that indicates the arrival of the abutment load? (2) What threshold would be consistent with the measuring method sensitivity of those measurements considered by Peng and Chiang (for which a description is absent from their work)?

Figure 42 shows a typical BPC curve from Mine A with smoothing of the data accomplished using a 9-point rolling average. If the lowest pressure is taken as the datum and increases in pressure are noted after that point, the figure shows how various stress increase thresholds would affect the determination of distance ahead of the face at which mining-induced abutment load is detected. Larson and Whyatt [2012] determined that for their system of sensors and dataloggers, 
a 69-kPa (10-psi) threshold was possible, where sensitivity with a pressure transducer range with a 14-bit datalogger system resulted in the ability to distinguish readings in increments of about $14 \mathrm{kPa}$ ( $2 \mathrm{psi}$ ). Considering the unknown but likely sensitivity of measurements considered by Peng and Chiang from over 30 years ago (possibly with chart recorders or manual readout boxes), Larson and Whyatt ultimately decided on the 138-kPa (20-psi) threshold for BPCs. Parallel analysis of the support Can systems, where the sensitivity of the system was around $6 \mathrm{lb}$, led to establishing the instrumented support Can threshold at $267 \mathrm{~N}(60 \mathrm{lb})$, or 0.3 tons. For ground condition surveys, Larson and Whyatt [2012] examined survey data taken at the outby sites and decided that a rating index increase of 0.5 in any of the roof, ribs, or floor at these specific locations might be tested as an indicator of the arrival of mining-induced stress. They found that of these three methods, measuring BPC pressures provided the most sensitivity, followed by support Cans, and lastly, ground condition surveys. The frequency of ground condition surveys did not permit accurate comparison of ground condition surveys with other methods as an indicator of the first arrival of mining-induced abutment stress.

Observations and measurements at Mine B for determining first arrival of abutment load and equivalent load transfer distance have not been published previously. Here, in addition to BPC cell pressures, support Can loads, entry closures, and ground condition surveys, one additional method was tested to determine whether it could reasonably sense the arrival of the mininginduced abutment stress. The method was measuring closure of various parts of the support Cans. Therefore, this method is assessed and compared with the other methods used at Mine A, some of which were previously published [Larson and Whyatt 2012].

Finally, a recent technical audit of production reports at Mine A resulted in updating several face longwall positions at the beginning and ending of shifts. Accordingly, measurements of distance of the face from the instrument line when the threshold was met may have some slight differences compared to that reported earlier [Larson and Whyatt 2012]. Hourly face position data were obtained by using beginning and ending shift face positions from production reports, reconciling obvious errors, and then assuming that the face advanced at a maximum rate of 1.9 $\mathrm{m} / \mathrm{hr}(6.25 \mathrm{ft} / \mathrm{hr})$ until the end-of-shift position was reached. The reason for this assumption was, through the observation of the authors, that most production occurred from the start of the shift onward until the level of methane that was released because of mining became too high for mining to continue safely. Most of the time, mining did not resume for the rest of the shift. By comparison, the production rate at Mine B was assumed to be constant between beginning and ending of shift face position. 


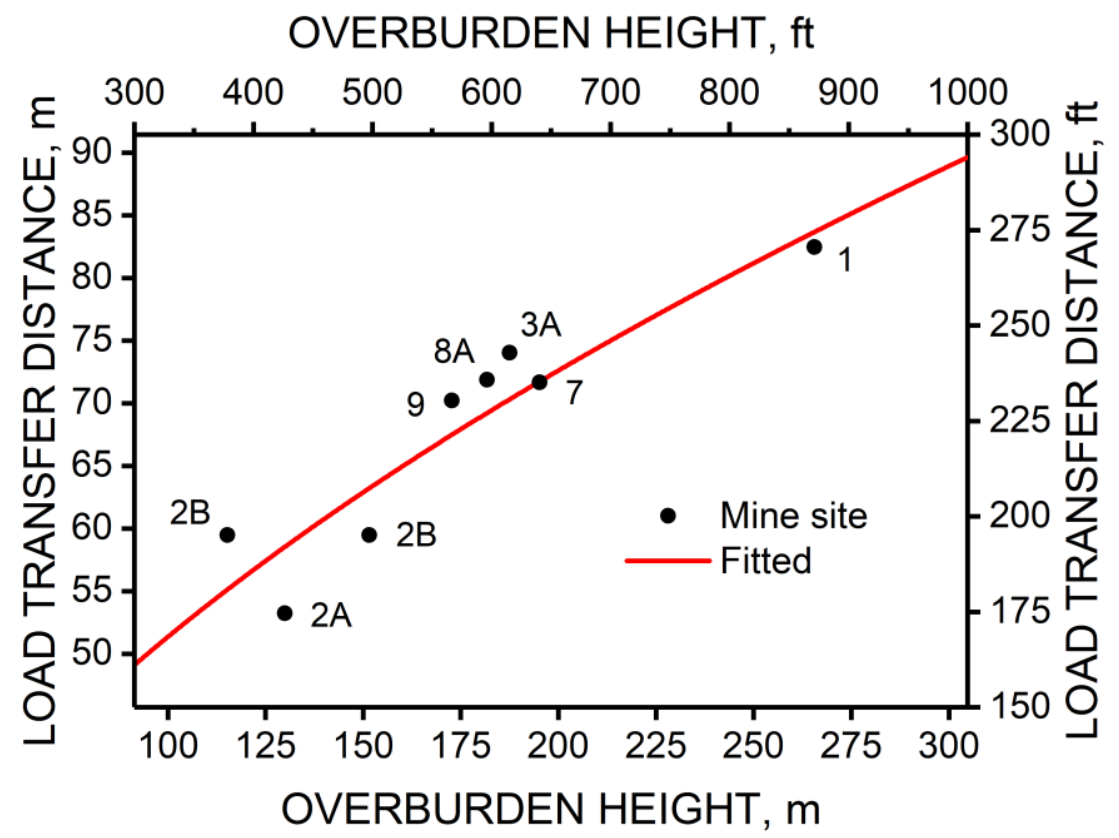

Figure 41. Measured load transfer distance versus seam depth for several cases in the eastern United States. A fitted line resulted in the empirical equation for load transfer distance. After Peng and Chiang [1984].

LOCATION OF FACE WITH RESPECT TO BPC LINE, ft

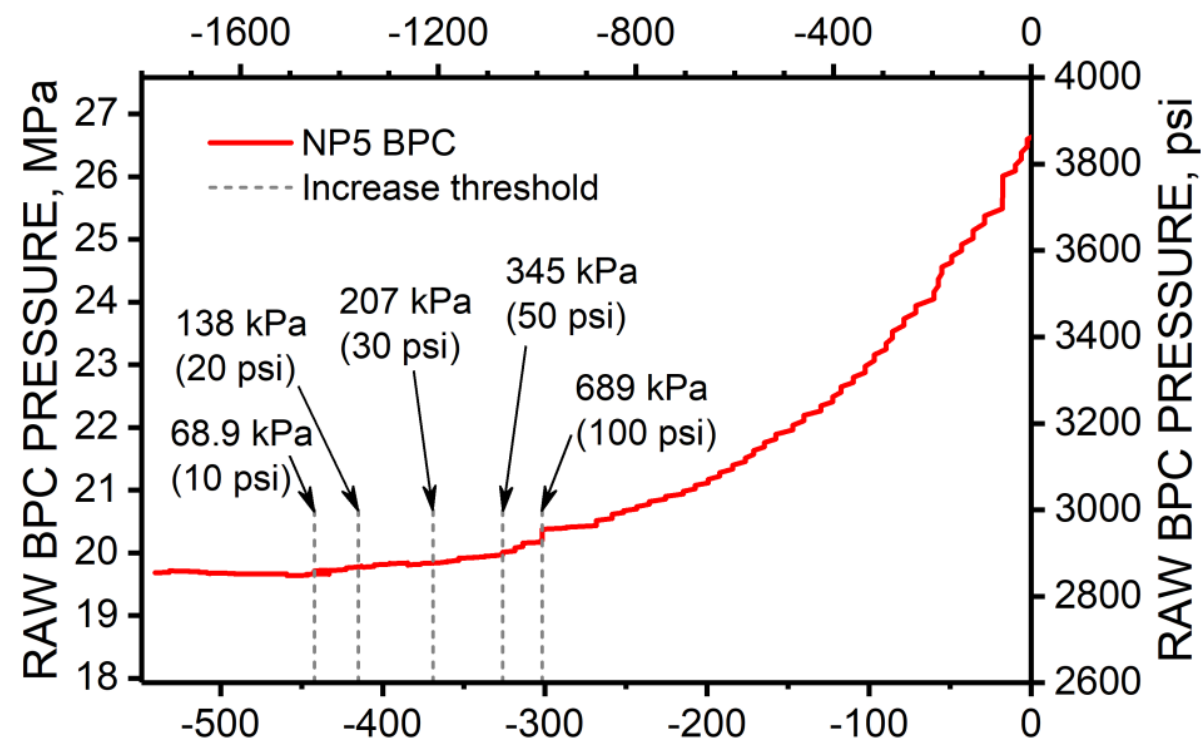

\section{LOCATION OF FACE WITH RESPECT TO BPC LINE, $m$}

Figure 42. Typical raw BPC pressure versus location of longwall face with respect to the BPC instrument line. A negative location means the face inby the BPC line. Also shown are the locations of various thresholds of increase in cell pressure. After Larson and Whyatt [2012]. 


\section{Measured-Borehole Pressure Cells}

\section{Mine $A$}

BPCs at Mine A were evaluated for use in determining arrival of mining-induced abutment stress during mining of Panel 1 only. Only BPCs at the outby sites were used because the inby sites were found to be too close to the startup room for baseline cell pressure trends to be established that were undisturbed by mining. However, to ensure quality of the measurements at the outby sites, specific criteria were used to eliminate instruments from consideration. As described by Larson and Whyatt [2012], criteria for elimination were:

1. Erratic readings;

2. A pressure bleed-off, even if minor, as it muddles determination of stress arrival;

3. Installation notes indicating BPCs may have been damaged during installation; and

4. Significant inconsistencies with adjacent instruments (this screens local effects as well as poorly performing cells).

With these criteria, BP1 at the 1 North outby site and all cells, except NP3, NP4, NP5, NP6, and NP7, at the 2 North outby site were eliminated for determining distance from the face at which the abutment stress first arrived. Following this criteria, all 2 North outby BPCs were eliminated from consideration for determining front abutment arrival during mining of Panel 2.

Figures of BPC pressures versus time are not shown, as they were similar to Figure 42. Table 10 lists, for the 1 North outby BPCs, lateral distances of each instrument from the eventual rib that would mark the boundary between the gate road pillar system and the gob, the distance from the face along the gate road at which each instrument detected a 138-kPa (20-psi) increase in stress, and the straight-line distance from the corner of the gob to the BPC when that stressincrease threshold was met. Table 11 lists the same for BPCs at the 2 North outby station. Average overburden heights at the 1 North outby site and 2 North outby sites were $682.33 \mathrm{~m}$ $(2,238.6 \mathrm{ft})$ and $691.41 \mathrm{~m}(2,268.4 \mathrm{ft})$, respectively, for an average of $686.87 \mathrm{~m}(2,253.5 \mathrm{ft})$ between the two sites. 
Table 10. Distances from face along gate road of first indication of arrival of abutment stress at BPCs at 1 North outby station and resulting distance to gob corner-method of 138-kPa (20-psi) increase

\begin{tabular}{|c|c|c|c|c|c|c|}
\hline Instrument & $\begin{array}{c}\text { Lateral } \\
\text { distance, } \mathrm{m}\end{array}$ & $\begin{array}{c}\text { Lateral } \\
\text { distance, } \mathrm{ft}\end{array}$ & $\begin{array}{l}\text { Distance } \\
\text { along panel, } \\
\text { m }\end{array}$ & $\begin{array}{c}\text { Distance } \\
\text { along panel, } \\
\text { ft }\end{array}$ & $\begin{array}{c}\text { Net } \\
\text { distance to } \\
\text { gob corner, } \\
\text { m }\end{array}$ & $\begin{array}{c}\text { Net } \\
\text { distance to } \\
\text { gob corner, } \\
\text { ft }\end{array}$ \\
\hline BP2 & 87.2 & 286 & 443.1 & $1,453.6$ & 451.6 & $1,481.5$ \\
\hline BP3 & 116.1 & 381 & 504.4 & $1,655.0$ & 517.6 & $1,698.3$ \\
\hline NP1 & 20.0 & 65.5 & 481.7 & $1,580.5$ & 482.1 & $1,581.8$ \\
\hline NP2 & 16.9 & 55.5 & 495.3 & $1,625.0$ & 495.6 & $1,625.9$ \\
\hline NP3 & 11.1 & 36.5 & 473.0 & $1,551.7$ & 473.1 & $1,552.2$ \\
\hline NP4 & 5.3 & 17.5 & 471.8 & $1,548.0$ & 471.8 & $1,548.1$ \\
\hline NP5 & 2.3 & 7.5 & 486.0 & $1,594.6$ & 486.0 & $1,594.6$ \\
\hline SP1 & 30.6 & 100.5 & 441.5 & $1,448.4$ & 442.5 & $1,451.8$ \\
\hline SP2 & 33.7 & 110.5 & 467.3 & $1,533.0$ & 468.5 & $1,537.0$ \\
\hline SP3 & 39.5 & 129.5 & 469.3 & $1,539.6$ & 470.9 & $1,545.0$ \\
\hline SP4 & 45.3 & 148.5 & 504.7 & $1,655.8$ & 506.7 & $1,662.4$ \\
\hline SP5 & 48.3 & 158.5 & 485.0 & $1,591.2$ & 487.4 & $1,599.1$ \\
\hline $\begin{array}{l}\text { Average } \\
\text { St. Dev. }\end{array}$ & & & & & $\begin{array}{c}479.5 \\
21.3\end{array}$ & $\begin{array}{c}1,573.1 \\
70.0\end{array}$ \\
\hline
\end{tabular}

Table 11. Distance from face along gate road of first indication of arrival of abutment stress at BPCs at 2 North outby station and resulting distance to gob corner-method of 138-kPa (20-psi) increase

\begin{tabular}{|c|c|c|c|c|c|c|}
\hline Instrument & $\begin{array}{l}\text { Lateral } \\
\text { distance, } \\
\text { m }\end{array}$ & $\begin{array}{c}\text { Lateral } \\
\text { distance, } \\
\mathbf{f t}\end{array}$ & $\begin{array}{l}\text { Distance } \\
\text { along } \\
\text { panel, m }\end{array}$ & $\begin{array}{l}\text { Distance } \\
\text { along } \\
\text { panel, ft }\end{array}$ & $\begin{array}{l}\text { Distance } \\
\text { to gob } \\
\text { corner, } m\end{array}$ & $\begin{array}{l}\text { Distance } \\
\text { to gob } \\
\text { corner, ft }\end{array}$ \\
\hline NP3 & 69.3 & 227.5 & 458.5 & $1,504.4$ & 463.7 & $1,521.4$ \\
\hline NP4 & 83.8 & 275 & 423.3 & $1,388.8$ & 431.5 & $1,415.8$ \\
\hline NP5 & 98.3 & 322.5 & 406.6 & $1,334.1$ & 418.3 & $1,372.5$ \\
\hline NP6 & 104.4 & 342.5 & 442.3 & $1,451.0$ & 454.4 & $1,490.9$ \\
\hline NP7 & 107.4 & 352.5 & 415.5 & $1,363.0$ & 429.1 & $1,407.9$ \\
\hline $\begin{array}{l}\text { Average } \\
\text { St. Dev. }\end{array}$ & & & & & $\begin{array}{c}439.4 \\
18.9\end{array}$ & $\begin{array}{c}1,441.7 \\
62.0\end{array}$ \\
\hline
\end{tabular}

Three important observations are noteworthy from these results:

- Even though the method of converting these distances to the gob corner to equivalent side abutment load transfer distances has not been detailed in this report, it is expected that some divisor in the range of 0.7 to 0.9 will be appropriate to make that conversion. That conversion is discussed and applied by Larson et al. in Ground Stress in Mining Part 2 [NIOSH 2020]. However, using this estimated range of conversion factors, the equivalent side abutment load transfer distances will be somewhere in the range of 3.6 to 5.1 times the empirically calculated load transfer distance of Equation 4 shown in the Review of Concept section of this report [Peng and Chiang 1984]. 
- The scatter of these measurements is relatively small, as indicated by the standard deviations of each site and the graphical scatter shown in Figures 43 and 44, where location of each BPC is superimposed with respect to the average location of the longwall face for the respective site (1 North and 2 North) when the stress-increase threshold was met.

- The ability to show stress increase near the rib (at $2.3 \mathrm{~m}[7.5 \mathrm{ft}]$ of depth) at comparable distance to that of the other BPCs suggests that a coal material model of yielding followed by perfectly plastic behavior or softening is not appropriate in this case. For this kind of model to be appropriate, the yield strength would have to be unrealistically high. These measurements strongly suggest that some other type of model would be more appropriate.
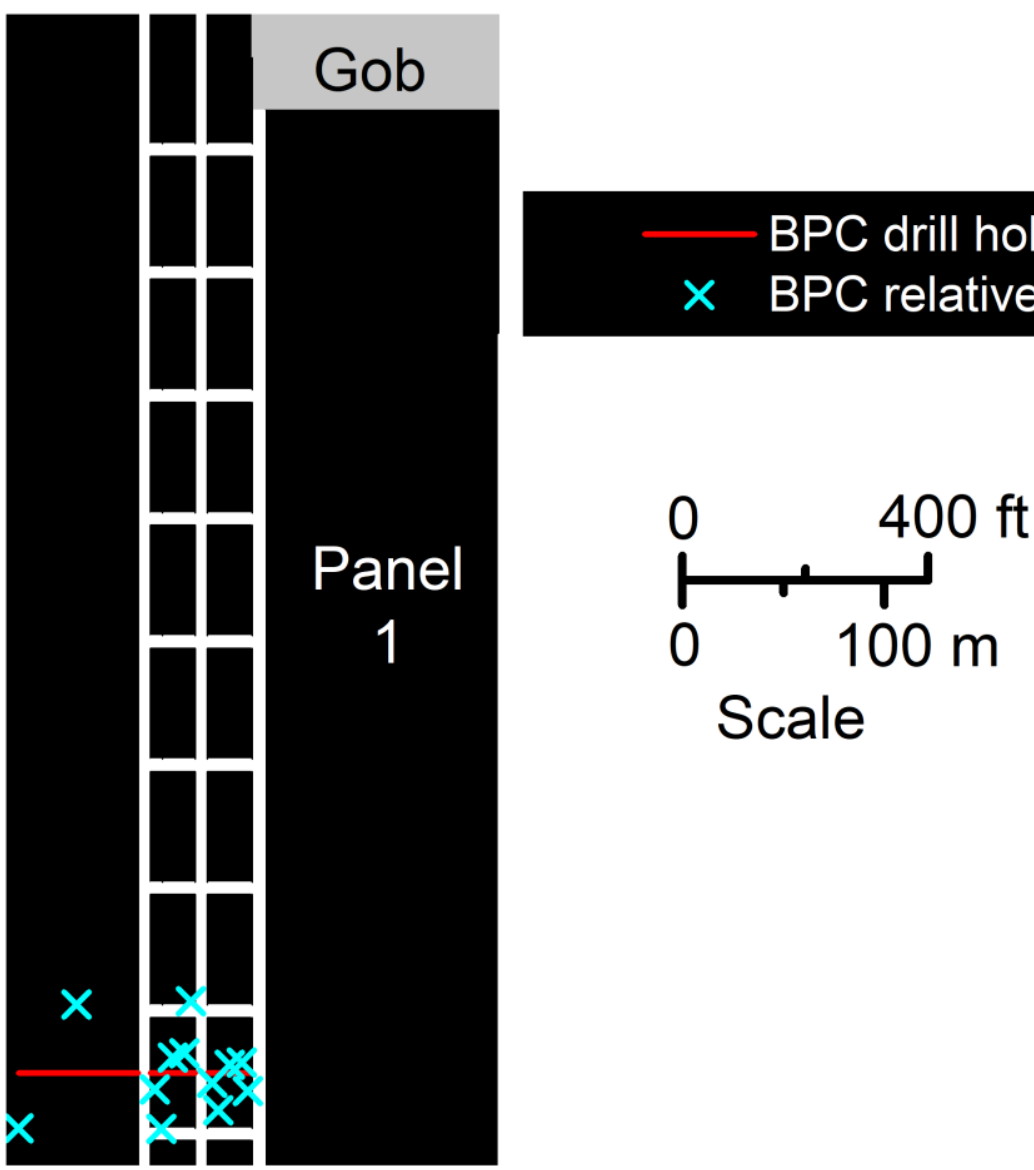

Figure 43. Relative position of BPCs in 1 North when the stress-increase threshold was reached. These relative positions are superimposed in the gate road geometry with respect to the face, where the face is shown at the average distance along the entries from the BPC drill holes when the stress-increase threshold was met at each BPC. 


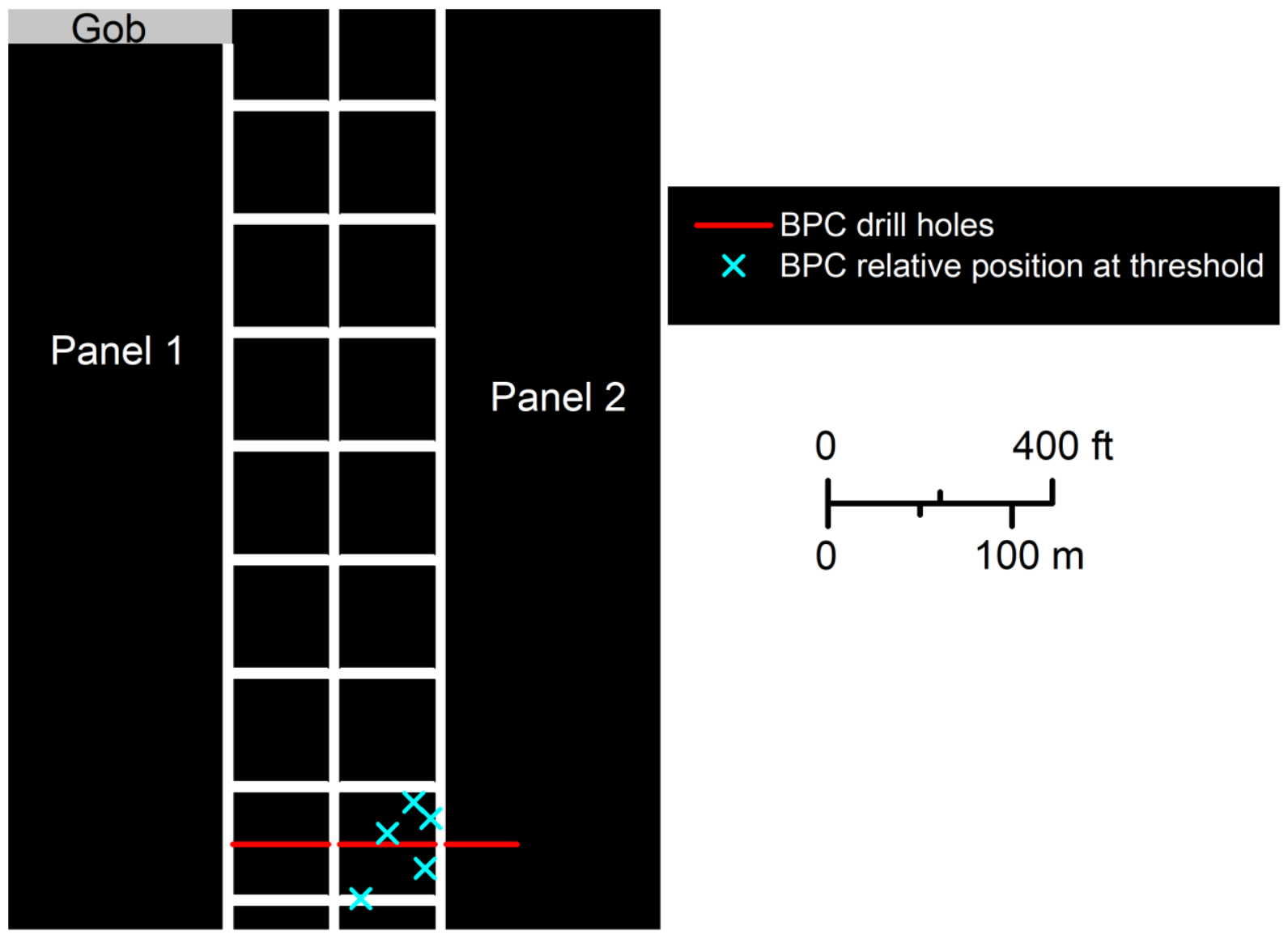

Figure 44. Relative position of BPCs in 2 North when stress-increase threshold was reached. These relative positions are superimposed in the gate road geometry with respect to the face, where the face is shown at the average distance along the entries from the BPC drill holes when the stress-increase threshold was met at each BPC.

\section{Mine $B$}

The BPC data were analyzed under the assumption that fluid leakage, void space caused by incomplete grout filling, or rubble in the grout contributed to downward trends and increased noise in the curves. It was further assumed that the trends of these contributions were generally smooth, and that stress increase caused departure from those trends. Admittedly, there is no way of assessing whether these assumptions are valid. They may be entirely false. However, alternative explanations, such as an arc effect [Zingano et al. 2004] causing unloading of pillars ahead of the face, pillar failure, and borehole degradation did not seem feasible, so that analysis proceeded for the purpose of examining whether the interpreted results were consistent among themselves and with the results at Mine A. Any discussion of confidence level is relative and based on these assumptions being true.

BPCs located at T21 and H22 were evaluated to determine the distance from the face at which first arrival of abutment stress was detected. This was done during mining of the B-12 panel only. A modification of the 20-psi threshold was used for detection because of the initial downward trends that were characteristic of all curves. The possible reasons for such trends were discussed earlier. Therefore, selected points from the initial downward curve were used to fit an equation to represent the average initial cell pressure trend. The various equations chosen to be 
fitted were selected for adequacy in describing the trend and in reasonably extrapolating the curve outside of the range of those points as the distance to the face decreased.

Figure 45 shows the pressure versus distance along the entry to the face from the BPC located in the pillar at $14.0 \mathrm{~m}$ (46 ft) (see Figure 22). A 9-point rolling average of the cell pressure was used to smooth the cell pressure curve. Points used for fitting a curve are shown. These points were chosen because they represented an average of several adjacent measurements, they were spaced periodically, and the expected distance at first arrival of abutment stress was expected to be less than all of these distances, based on experience at Mine A.

A fourth-order polynomial was fitted to the points, giving 10 times weight in fitting to the point closest to the face so that error between that point and the fitted equation might be reduced. This equation was selected for fitting because of its high correlation coefficient $\left(\mathrm{r}^{2}\right)$, because it was simple, and because its extrapolation for the first cases appeared to be reasonable. However, care must be taken to not extrapolate much beyond the fitted points, because higher-order polynomials change from concave to convex trends and vice versa, which may not be physically representative of the response caused by leakage, rubble, or void space caused by incomplete grout filling. Therefore, certainty of the determination of first arrival of abutment stress is not high as it was at Mine A.

For example, one might argue that an initial curve ending in a linear trend would be more appropriate in Figure 45, which would make the distance from the face at first arrival to be greater in absolute value than is indicated with the fitted polynomial curve. Toward this argument, the fitted polynomial curve decreases in slope immediately after the fitted points before trending at an even greater slope than the tangent to the curve at the last fitted point. Thus, error produced by extrapolating with the fourth-order polynomial is minimized in the range where first arrival was determined. In any event, there seems to be a slight departure of cell pressure from the initial trend somewhere in the range of $150 \mathrm{~m}$ to $250 \mathrm{~m}$ (492 $\mathrm{ft}$ to $820 \mathrm{ft}$ ) inby the instrument. The distance from the face at which first arrival of abutment load was detected is determined as the distance at which the curve increased $138 \mathrm{kPa}(20 \mathrm{psi})$ above the initial trend curve. That distance, indicated in the figure, is $193.5 \mathrm{~m}(634.8 \mathrm{ft})$ inby the instrument (indicated by the negative sign in the figure). Engineering judgment could have eliminated some of the right-most fitting points, so that first arrival might have been at approximately $250 \mathrm{~m}(820 \mathrm{ft})$. 


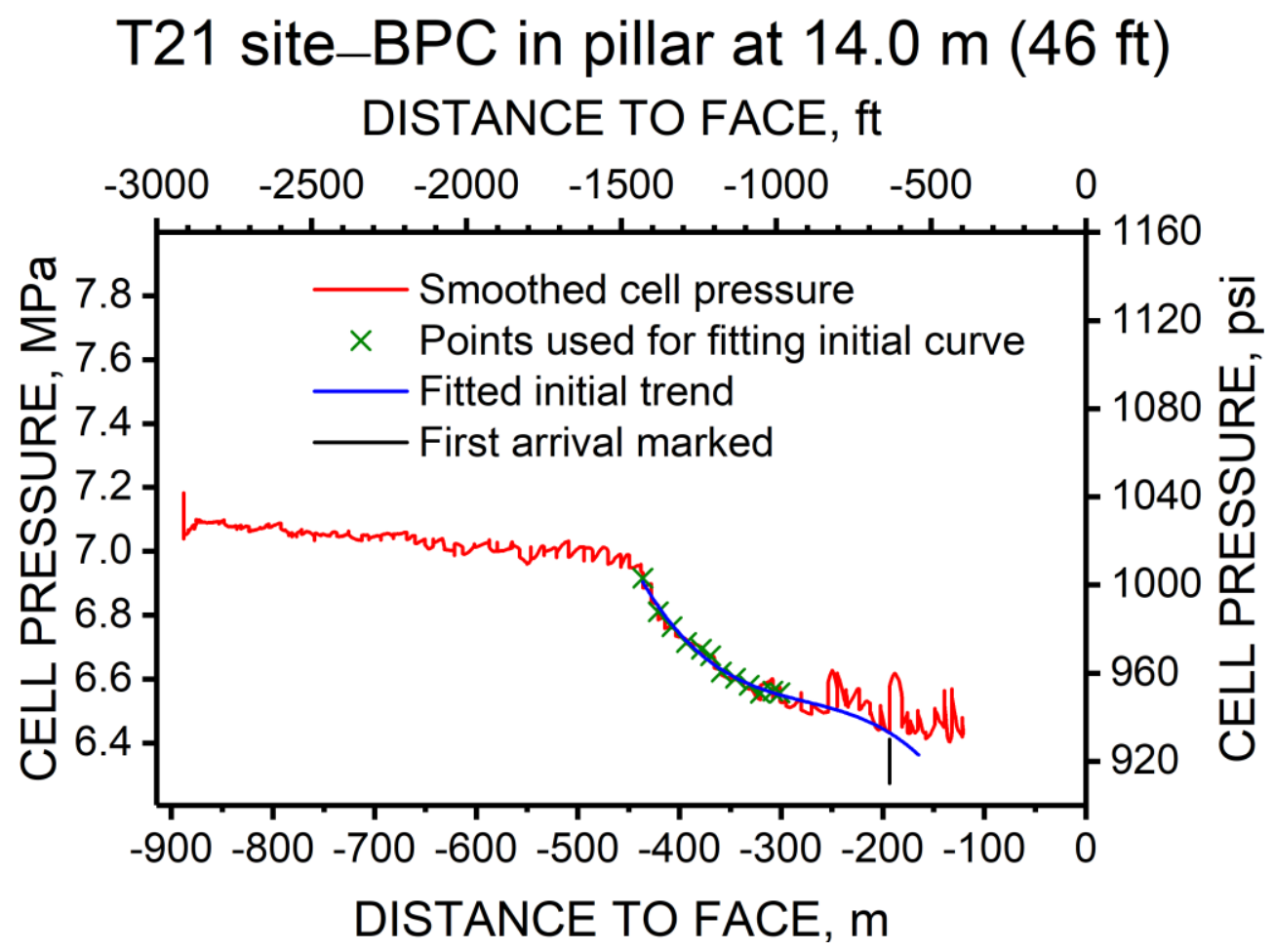

Figure 45. BPC in the pillar at $14.0 \mathrm{~m}$ (46 ft) with distance from face at T21 site at Mine B. Initial trend line is shown and points are marked from which the curve was fitted. First arrival is marked where departure from fitted curve meets detection threshold.

Figure 46 shows pressure versus distance to the face from the BPC at $3.7 \mathrm{~m} \mathrm{(12} \mathrm{ft)} \mathrm{of} \mathrm{depth}$ into the pillar (as in Figure 22) at the T21 site. Here, the trend of the initial pressure can be interpreted several ways. Believing the first arrival to be inside $306 \mathrm{~m}(1,000 \mathrm{ft})$, points were selected for fitting that also included the portion of the curve with an upward trend. A fourthorder polynomial was fit to those points, and a first arrival distance of $278.5 \mathrm{~m}(913.9 \mathrm{ft})$ was determined. Alternatively, a straight line was fitted to the points in the downward trending portion of the curve, which is also shown in the figure, and a distance to face at first arrival of abutment stress was determined to be $399.1 \mathrm{~m}$ (1,309.4 ft). These two determinations might serve as the lower and upper bounds of a range, but the larger value, determined from just the downward portion of the curve, seems more plausible. 


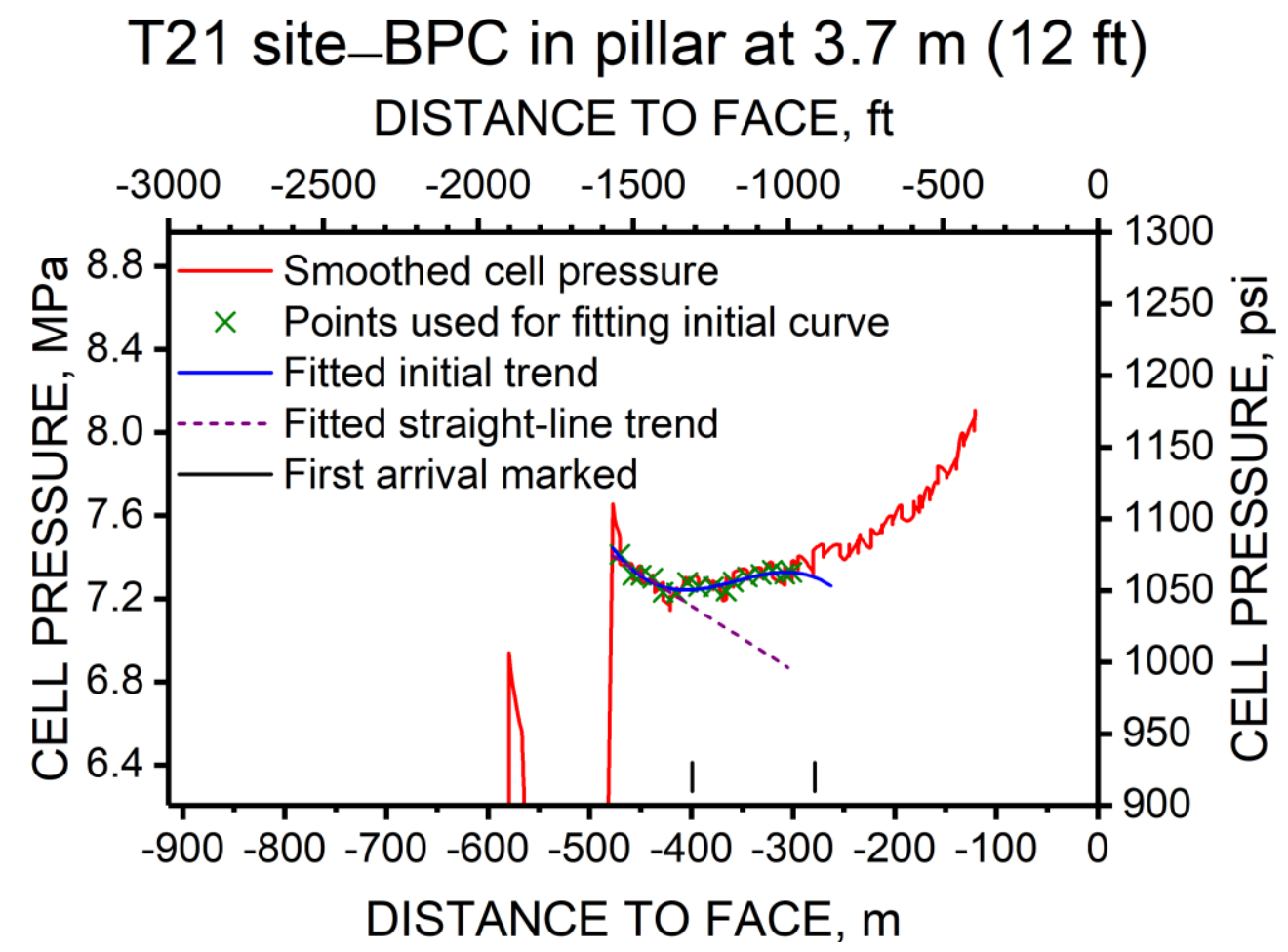

Figure 46. BPC in the pillar at $3.7 \mathrm{~m}(12 \mathrm{ft})$ with distance from face at T21 site at Mine $B$. Initial trend line is shown and points are marked from which the curve was fitted. Line was fitted to early marked points. First arrivals are marked where departure from fitted curves meets detection threshold.

Figure 47 shows pressure versus distance to the face of the BPC at the T21 site located in the B-13 panel at a depth of $3.7 \mathrm{~m} \mathrm{(12} \mathrm{ft).} \mathrm{A} \mathrm{fourth-order} \mathrm{polynomial} \mathrm{was} \mathrm{fitted} \mathrm{to} \mathrm{all} \mathrm{of} \mathrm{the}$ indicated points except the left three. As indicated earlier, the original points were selected for fitting an equation because the first arrival of abutment stress was expected to be closer to the face than these points, based on experience at Mine A. The downward trend of the fitted curve to the right of the sampled points is not realistic, so that perhaps a better equation might be chosen, but a slight increase in cell pressure above the initial trend seems to be indicated. The polynomial curve has only minimal expected error within a short distance of the last fitted point. Therefore, the usual threshold for determining distance to the face at first arrival of abutment stress was applied against this fitted curve, indicating a distance of $260.5 \mathrm{~m}(854.8 \mathrm{ft})$. If the three sampled points on the left-hand side are included and a straight line is fitted to the downward portion of these points (the left six points), another distance to the face at detection of first arrival of abutment stress is indicated as $366.7 \mathrm{~m}(1,203 \mathrm{ft})$. These two distances might be used as upper and lower bounds of the distance to first arrival of abutment stress. 


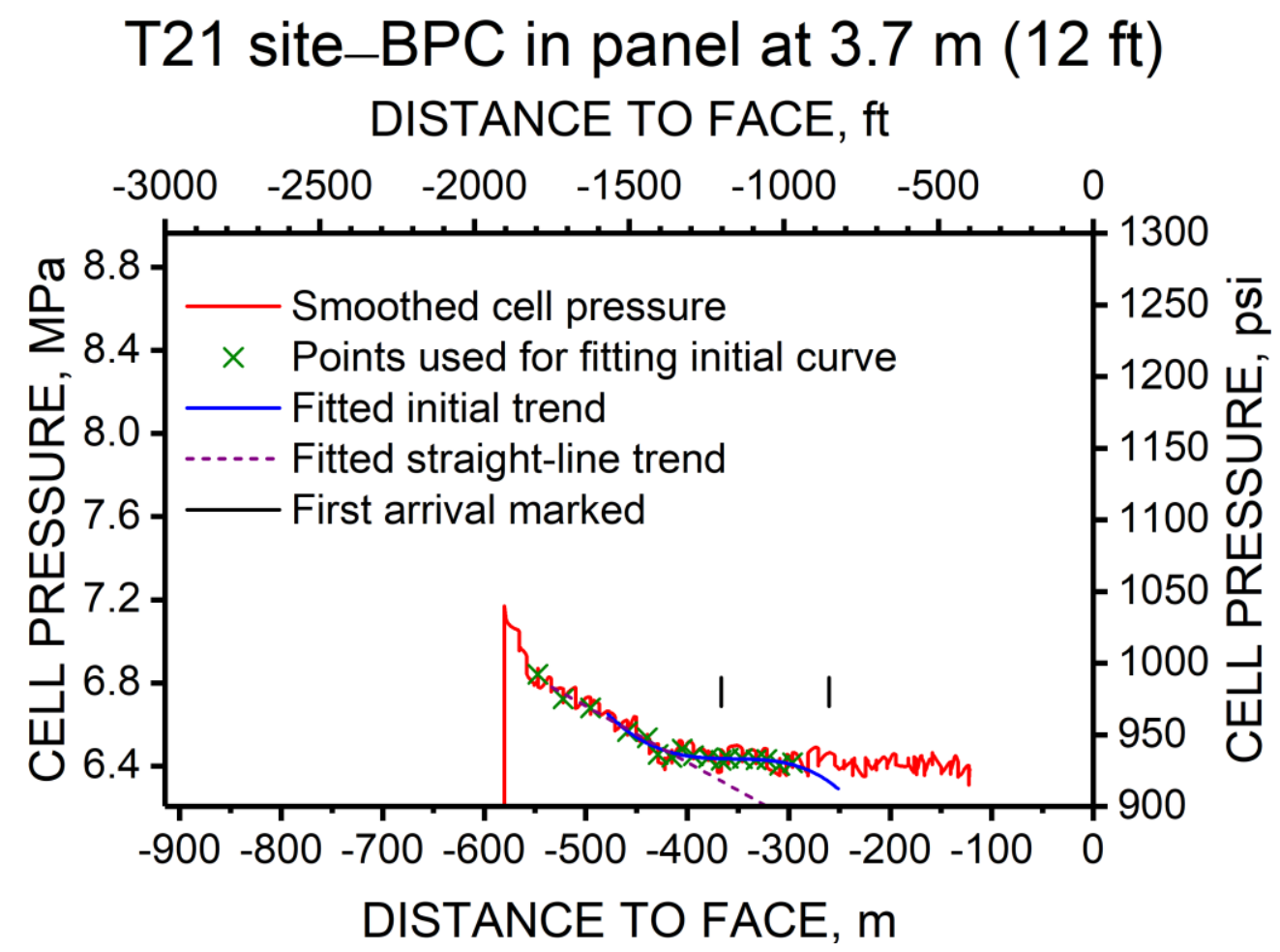

Figure 47. BPC in the panel at $3.7 \mathrm{~m} \mathrm{(12} \mathrm{ft)} \mathrm{with} \mathrm{distance} \mathrm{from} \mathrm{face} \mathrm{at} \mathrm{T21} \mathrm{site} \mathrm{at} \mathrm{Mine} \mathrm{B.}$ Initial trend line is shown and points are marked from which the curve was fitted. Left three marked points were not used to fit the initial curve. Line was fitted to the eight leftmost marked points, including three not included in fitting the polynomial curve. First arrivals are marked where departure from fitted curves meets detection threshold.

Figure 48 shows pressure versus distance to the face of the BPC at site $\mathrm{H} 22$ that is located in the pillar at $14.6 \mathrm{~m}$ (48 ft) of depth. Points for fitting to represent the initial trend of the curve were selected from areas of the smoothed curve that did not have temporary "humps." This selection makes departure from the initial trend more certain in this case. A second-order polynomial was sufficient to represent the initial trend more clearly. The threshold for determination of first arrival of mining-induced abutment stress was met when the face was $179.1 \mathrm{~m}(587.7 \mathrm{ft})$ inby the instrument.

The pressure versus distance to face of the BPC located at $3.7 \mathrm{~m}(12 \mathrm{ft})$ in the same pillar at H22, shown in Figure 49, does not show as clear a departure from the initial trend. Moreover, none of the polynomial equations seemed to extrapolate the initial trend well. Another equation was found to fit the trend reasonably well using the selected points. That equation was:

$$
y=a\left(1-e^{-b x}\right)^{c}+d
$$

where $a, b, c$, and $d=$ fitted constants,

$x=$ distance to face, and

$y=$ cell pressure. 


\section{$\mathrm{H} 22$ site-BPC in pillar at $14.6 \mathrm{~m}(48 \mathrm{ft})$} DISTANCE TO FACE, $\mathrm{ft}$

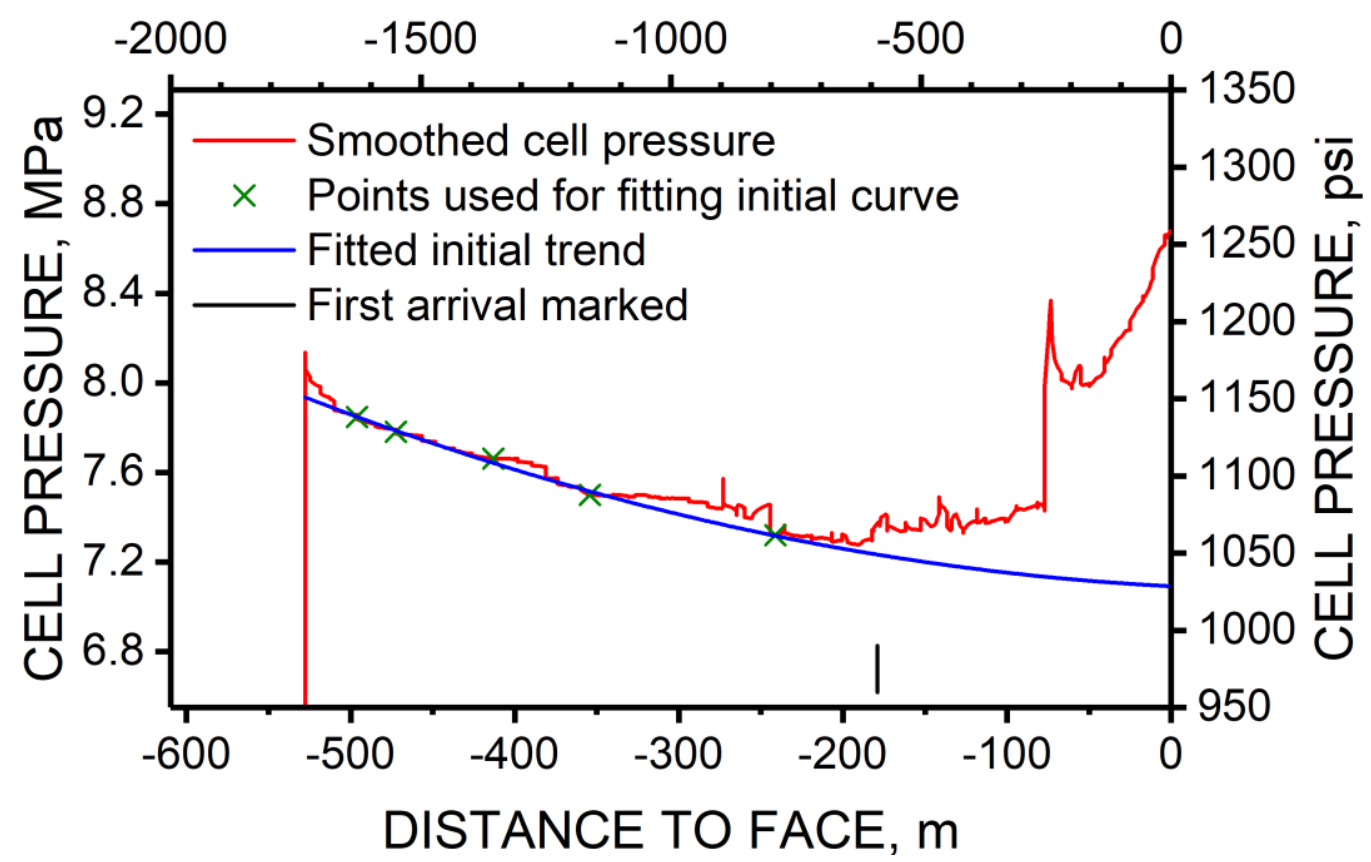

Figure 48. BPC in the pillar at $14.6 \mathrm{~m} \mathrm{(48} \mathrm{ft)} \mathrm{with} \mathrm{distance} \mathrm{from} \mathrm{face} \mathrm{at} \mathrm{H} 22$ site at Mine B. Initial trend line is shown and points are marked from which the curve was fitted. First arrival is marked where departure from fitted curve meets detection threshold.

Using this fitted curve, the threshold for determining distance to face at which mininginduced abutment stress first arrived is reached when the face was $176.8 \mathrm{~m}(579.9 \mathrm{ft})$ inby the BPC. However, the noise is what seems to trip the threshold departure. This first arrival would be rejected, if not for the general shift in trend from downward to level, and finally, to increasing slightly. This distance could be treated as a lower bound, given the change from downward initial trend to a more horizontal change when the face was between $300 \mathrm{~m}(984 \mathrm{ft})$ and $350 \mathrm{~m}$ $(1,148 \mathrm{ft})$ inby the BPC. The $176.8 \mathrm{~m}(579.9 \mathrm{ft})$ distance is compatible with the measurement at

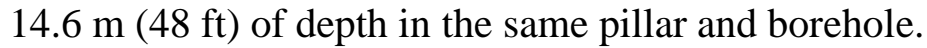

Figure 50 shows the smoothed BPC pressure at H22 in the B-13 panel at a depth of $3.7 \mathrm{~m} \mathrm{(12}$ $\mathrm{ft})$. The points selected for fitting are shown. Fitted points to the left of the unusual drop in cell pressure were given a constant offset for purposes of curve fitting. This was justified because elimination of the drop seemed to result in a plausible initial curve. In this case, another equation was necessarily chosen to fit the points and show reasonable extrapolation. The equation was:

$$
y=a^{\ln (b x+c)}+d
$$

where the variable definitions are the same as for Equation 5. As shown in Figure 49, there was no significant departure from the initial curve, such that no distance to the face was determined for first arrival of mining-induced abutment stress. 


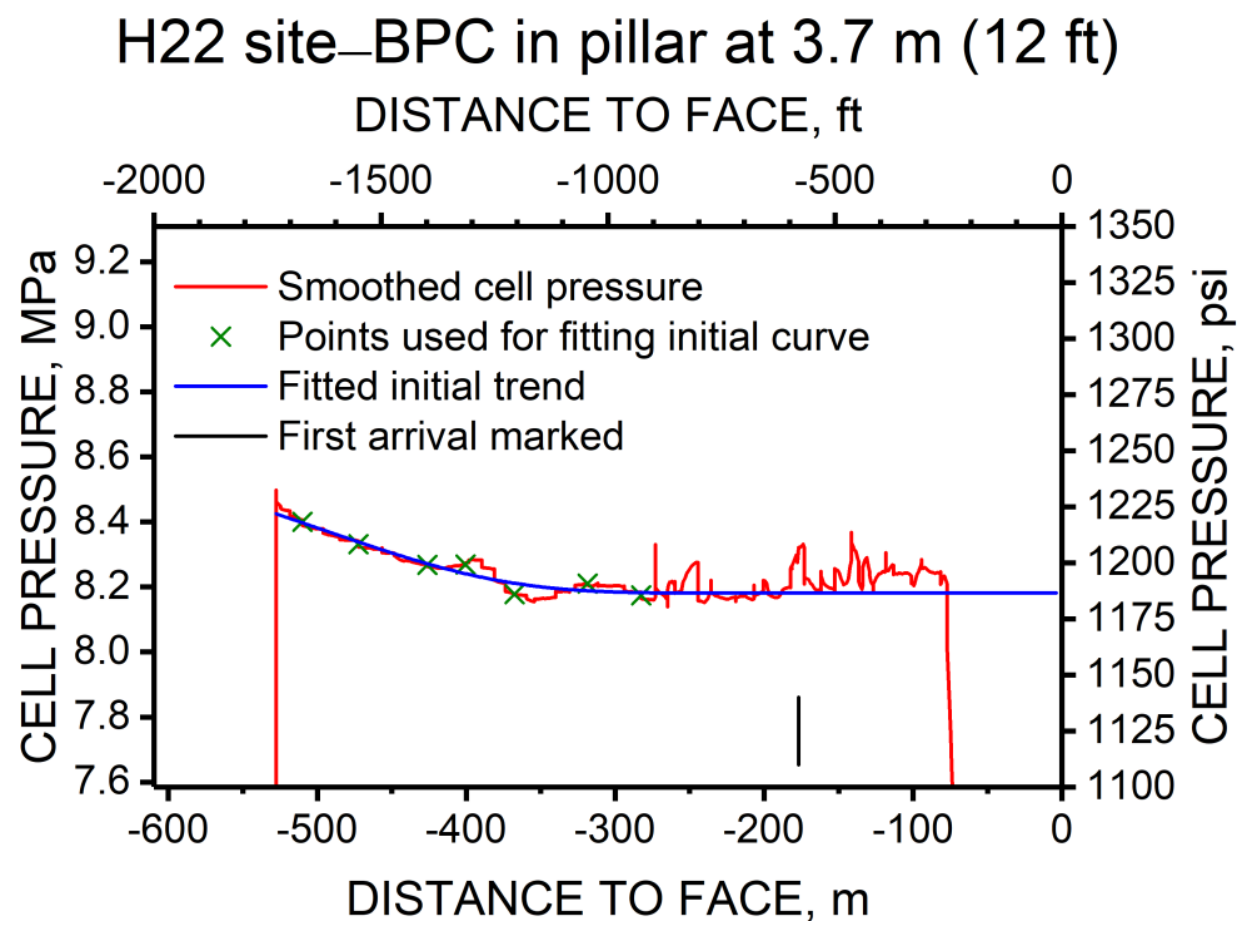

Figure 49. BPC in the pillar at $3.7 \mathrm{~m} \mathrm{(12} \mathrm{ft)} \mathrm{with} \mathrm{distance} \mathrm{from} \mathrm{face} \mathrm{at} \mathrm{H} 22$ site at Mine B. Initial trend line is shown and points are marked from which the curve was fitted. First arrival is marked where departure from fitted curve meets detection threshold.

$\mathrm{H} 22$ site-BPC in panel at $3.7 \mathrm{~m} \mathrm{(12} \mathrm{ft)}$ DISTANCE TO FACE, $\mathrm{ft}$

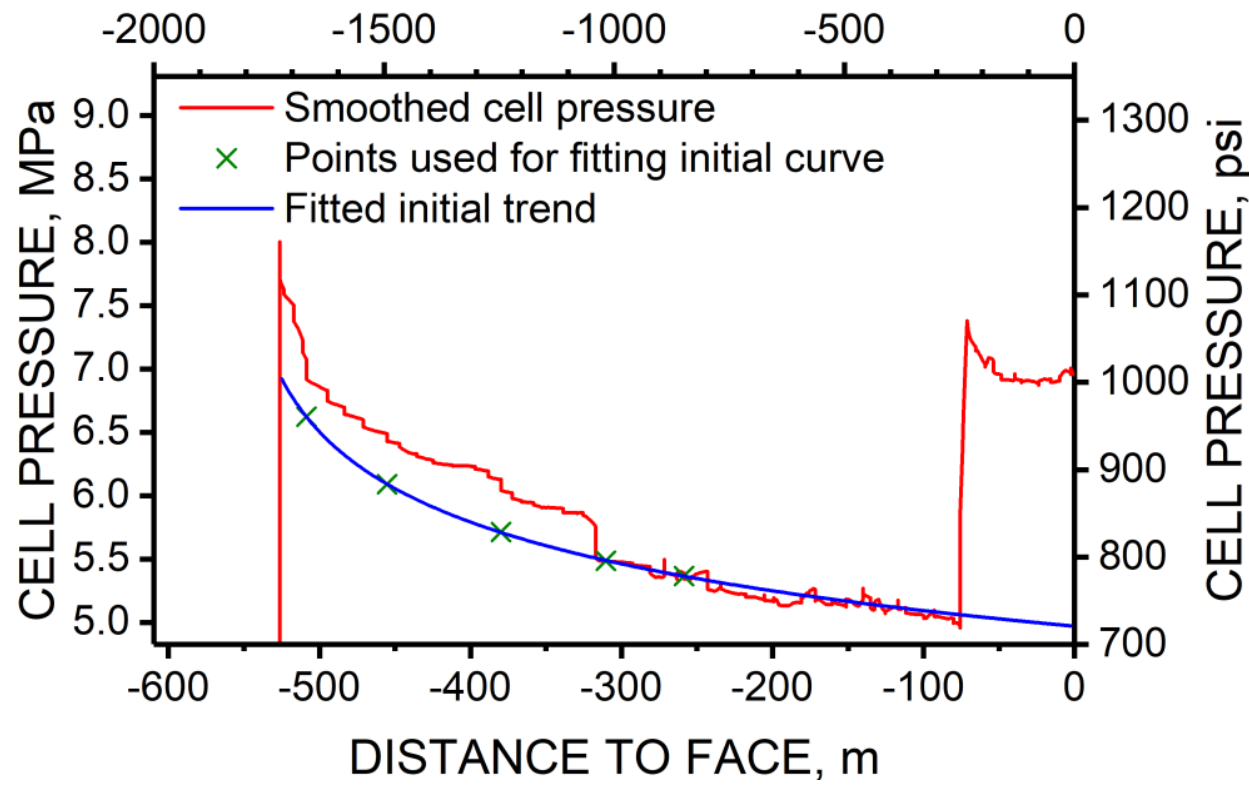

Figure 50. BPC in the panel at $3.7 \mathrm{~m} \mathrm{(12} \mathrm{ft)} \mathrm{with} \mathrm{distance} \mathrm{from} \mathrm{face} \mathrm{at} \mathrm{H} 22$ site at Mine B. Initial trend line is shown and points are marked from which the curve was fitted. Some points for fitting were offset to compensate for a jump in measurement curve at a distance to face of about $-320 \mathrm{~m}$ $(-1,050 \mathrm{ft})$. Detection of first arrival of abutment stress appears to be impossible in this case. 
For convenience in display and discussion, the results of measured distance from face to first arrival of mining-induced abutment stress are summarized in Table 12. Again, it is emphasized that these distances of first arrival are dependent on the assumption that the trends before first arrival are consistent and were caused by presence of voids or coal rubble in the grout around the instrument or may have been caused by slow hydraulic leakage. The confidence level in the data, therefore, is relatively low. However, if the assumption is true, the results deserve further examination.

From the table, it appears that the distance to face at first arrival of abutment stress is greater as measured at the tailgate station BPCs than it is as measured at the headgate station BPCs. This observation is consistent with expected increase in stress that is typical in unmined panels near tailgates as compared with that near headgate entries under similar overburden height. Also, measured distances to the face at first arrival of abutment stress are less than those at Mine A as measured with BPCs. This is consistent with less overburden thickness at Mine B, and therefore, less potential for transferring overpanel weight to locations far away from the mined panel. Lastly, these first arrival distances from the face are not load transfer distances. Equivalent load transfer distances must be established with the aid of modeling. Such a procedure was shown by Larson and Whyatt [2012] but was analyzed more appropriately for this data by Larson et al. in Ground Stress in Mining Part 2 [NIOSH 2020].

Table 12. Summary of distance to face at first arrival of mining-induced abutment stress as measured with BPCs at Mine B

\begin{tabular}{|c|c|c|c|c|c|c|}
\hline Site & BPC & $\begin{array}{l}\text { Lateral } \\
\text { distance } \\
\text { from gob } \\
\text { corner, } \\
\text { m (ft) }\end{array}$ & $\begin{array}{l}\text { Distance } \\
\text { from } \\
\text { instrument to } \\
\text { face along } \\
\text { entry, } \mathrm{m} \text { (ft) }\end{array}$ & $\begin{array}{l}\text { Net } \\
\text { distance to } \\
\text { gob } \\
\text { corner, m } \\
\text { (ft) }\end{array}$ & Confidence $^{\dagger}$ & Comments \\
\hline T21 & $\begin{array}{l}\text { In pillar at } \\
14.0 \mathrm{~m} \\
(46 \mathrm{ft})\end{array}$ & $14.0(46)$ & $193.5(634.8)$ & $194.0(636.5)$ & Low & $\begin{array}{l}\text { Can argue an } \\
\text { upper bound of } \\
\text { distance along } \\
\text { entry to face of } \\
\text { about } 250 \mathrm{~m} \text { ( } 820 \\
\mathrm{ft} \text { ) }\end{array}$ \\
\hline T21 & $\begin{array}{l}\text { In pillar at } \\
3.7 \mathrm{~m} \mathrm{(12} \\
\mathrm{ft})\end{array}$ & $3.7(12)$ & $\begin{array}{l}278.5 \text { to } 399.1 \\
(913.9 \text { to } \\
1,309.4)\end{array}$ & $\begin{array}{l}278.6 \text { to } 399.1 \\
(914.0 \text { to } \\
1,309)\end{array}$ & $\begin{array}{l}\text { Fair to good that } \\
\text { first arrival is in } \\
\text { range indicated }\end{array}$ & $\begin{array}{l}\text { Slight to } \\
\text { moderate } \\
\text { departure from } \\
\text { initial trend for } \\
\text { lower bound }\end{array}$ \\
\hline T21 & $\begin{array}{l}\text { In panel at } \\
3.7 \mathrm{~m}(12 \\
\mathrm{ft})\end{array}$ & $-6.4(-21)$ & $\begin{array}{l}260.5 \text { to } 366.7 \\
(854.8 \text { to } 1203)\end{array}$ & $\begin{array}{l}260.6 \text { to } 366.8 \\
(855.0 \text { to } \\
1,203) \\
\end{array}$ & $\begin{array}{l}\text { Fair to good that } \\
\text { first arrival is in } \\
\text { range indicated }\end{array}$ & $\begin{array}{l}\text { Slight departure } \\
\text { from initial trend } \\
\text { for lower bound }\end{array}$ \\
\hline $\mathrm{H} 22$ & $\begin{array}{l}\text { In pillar at } \\
14.6 \mathrm{~m} \\
(48 \mathrm{ft}) \\
\end{array}$ & $39.6(130)$ & $179.1(587.7)$ & $183.5(601.9)$ & Good & $\begin{array}{l}\text { Clear departure } \\
\text { from initial trend }\end{array}$ \\
\hline $\mathrm{H} 22$ & $\begin{array}{l}\text { In pillar at } \\
3.7 \mathrm{~m}(12 \\
\mathrm{ft})\end{array}$ & $50.6(166)$ & $\begin{array}{l}176.8 \text { to } 300 \\
(579.9 \text { to } 984)\end{array}$ & $\begin{array}{l}183.9 \text { to } 304.2 \\
(603.2 \text { to } \\
997.9)\end{array}$ & Low & $\begin{array}{l}\text { Slight departure } \\
\text { from initial trend }\end{array}$ \\
\hline
\end{tabular}

†Relative confidence dependent on assumptions that downward trends were the result of leakage, rubble, or void space. 


\section{Measured-Support Cans}

\section{Mine $A$}

The threshold load increase for instrumented support Cans to determine the first arrival of mining-induced abutment stress is affected by sensitivities of the datalogger and the pressure transducer. The critical sensitivity was the number of bits covering the measurement range by the datalogger $(26.7 \mathrm{~N}[6.0 \mathrm{lb}])$. By following the same procedure as that used to determine the threshold for the BPCs, this sensitivity was multiplied by a factor of 10.0 to determine a threshold support Can load increase of $0.267 \mathrm{kN}$ (60 lb or 0.03 ton).

Larson and Whyatt [2012] used this threshold in analyzing Cans only from the intersection at crosscut 10. However, closer examination of data from all 10 instrumented Cans suggests some sensitivity to tightness and stiffness of the wooden cap pieces and wedges at the time of installation. If Larson and Whyatt [2012] had applied the same evaluation criteria of the BPCs to data of the four Cans in the intersection, data from all four Cans would have been discarded. In the case of BPCs, some initial drop in cell pressure was allowed if it was approximately the same magnitude of the stress-increase threshold. Applied thus to the support Cans, not only would data from the four at crosscut 10 be eliminated, but also data from Cans B, D, and E in entry 3 between crosscuts 9 and 10 would be eliminated for determining first arrival of abutment stress.

Accordingly, Table 13 has results from the remaining Cans showing distance at which the abutment stress was first detected, listing both distance along the gate road and straight-line distance to the gob corner. As it was for the BPCs, the scatter is small, as shown by the standard deviation and the superimposed scatter shown along with that of the BPCs in Figure 51.

As mentioned in connection with the BPCs, if the divisor to convert to equivalent load transfer distance is somewhere between 0.7 and 0.9 , then the ratio of equivalent side load transfer distance normalized by the empirically calculated Peng and Chiang [1984] load transfer distance would range from 3.4 to 4.3 , which is not unlike the range estimated earlier from BPC measurements at Mine A. From Figure 51 and these ratio ranges, it appears that the sensitivity of both BPCs and support Cans loads to abutment stress increase are nearly equivalent.

Table 13. Distance from face along gate road of first indication of arrival of abutment load at instrumented support Cans at 2 North outby station at Mine A and resulting distance to gob corner-method of 0.267-kN (0.03-ton) increase

\begin{tabular}{l|l|l|l|l|l|l}
\hline $\begin{array}{l}\text { Support } \\
\text { Can }\end{array}$ & $\begin{array}{l}\text { Lateral } \\
\text { distance, } \\
\mathbf{m}\end{array}$ & $\begin{array}{l}\text { Lateral } \\
\text { distance, } \\
\mathbf{f t}\end{array}$ & $\begin{array}{l}\text { Distance } \\
\text { along } \\
\text { panel, } \mathbf{m}\end{array}$ & $\begin{array}{l}\text { Distance } \\
\text { along } \\
\text { panel, ft }\end{array}$ & $\begin{array}{l}\text { Distance } \\
\text { to gob } \\
\text { corner, } \mathbf{m}\end{array}$ & $\begin{array}{l}\text { Distance } \\
\text { to gob } \\
\text { corner, ft }\end{array}$ \\
\hline A & 110.7 & 363.2 & 401.2 & 1316.2 & 416.2 & 1365.4 \\
\hline C & 110.7 & 363.2 & 396.5 & 1301.0 & 411.7 & 1350.7 \\
\hline F & 113.2 & 371.5 & 373.8 & 1226.5 & 390.6 & 1281.5 \\
\hline $\begin{array}{r}\text { Average } \\
\text { St. Dev. }\end{array}$
\end{tabular}




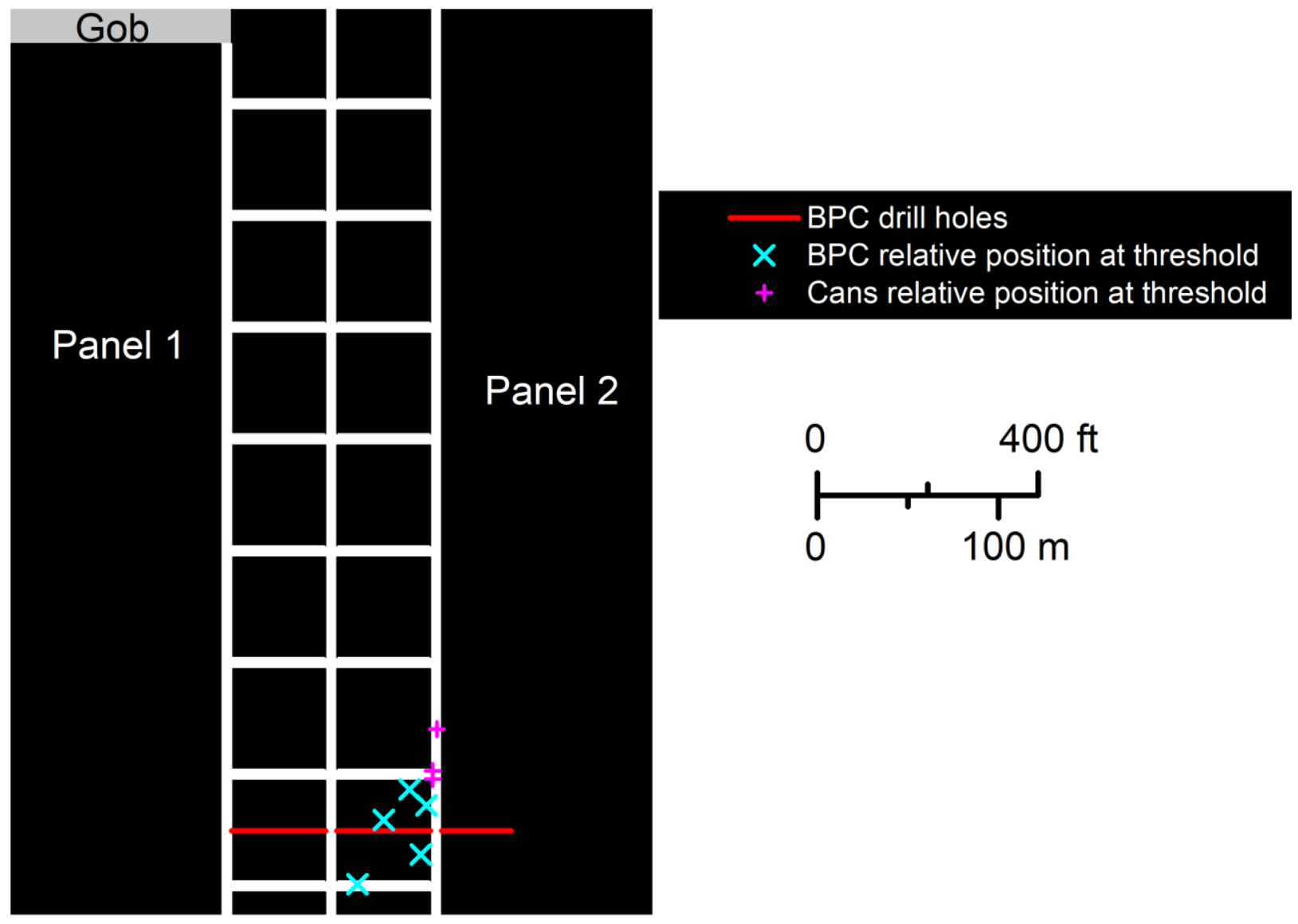

Figure 51. Relative position of support Cans along with BPCs in 2 North when the load-increase threshold was reached. These relative positions are superimposed in the gate road geometry with respect to the face, where the face is shown at the average distance along the entries from the BPC drill holes when the stress-increase threshold was met at each BPC. The proximity of the Cans to the BPCs indicates that the two sensing methods are nearly equal in sensitivity.

\section{Mine $B$}

As indicated in the Measurements section, the only support Can load curve that could be analyzed to determine distance from the face at first arrival of abutment distance is the outby Can at the $\mathrm{H} 21$ site. The load over time was noisy, even after applying the 9-point rolling average smoothing technique. The noise level exceeded the threshold for determination of distance at first arrival of mining-induced abutment load. Therefore, the load-increase threshold used at Mine A could not be applied. However, the point of increase of load above the noise level, shown in Figure 52, is very pronounced. Table 14 lists the lateral location from the gob corner of the instrument and the measurement of distance along the entry from the face that the first arrival of mining-induced abutment stress was detected. These numbers were used to calculate the direct distance from the Can to the gob at first arrival of abutment stress. An assumed yield distance of $6.1 \mathrm{~m}(20 \mathrm{ft})$ was subtracted from the total to be consistent with the calibration method in the LamPre gob wizard [Heasley 2010] - i.e., matching the distance from the gob at which $90 \%$ of the abutment load is transferred. In the LamPre wizard, the depth of yield is not included in that distance. The distance determined for this support Can is well above that determined with the BPCs and is well above the distances determined at Mine A. Rather than dismiss this 
measurement, the determination of distance to face at first arrival of abutment stress is examined with all determinations of distance to first arrivals from measurements made with various instruments that are discussed later in this report.

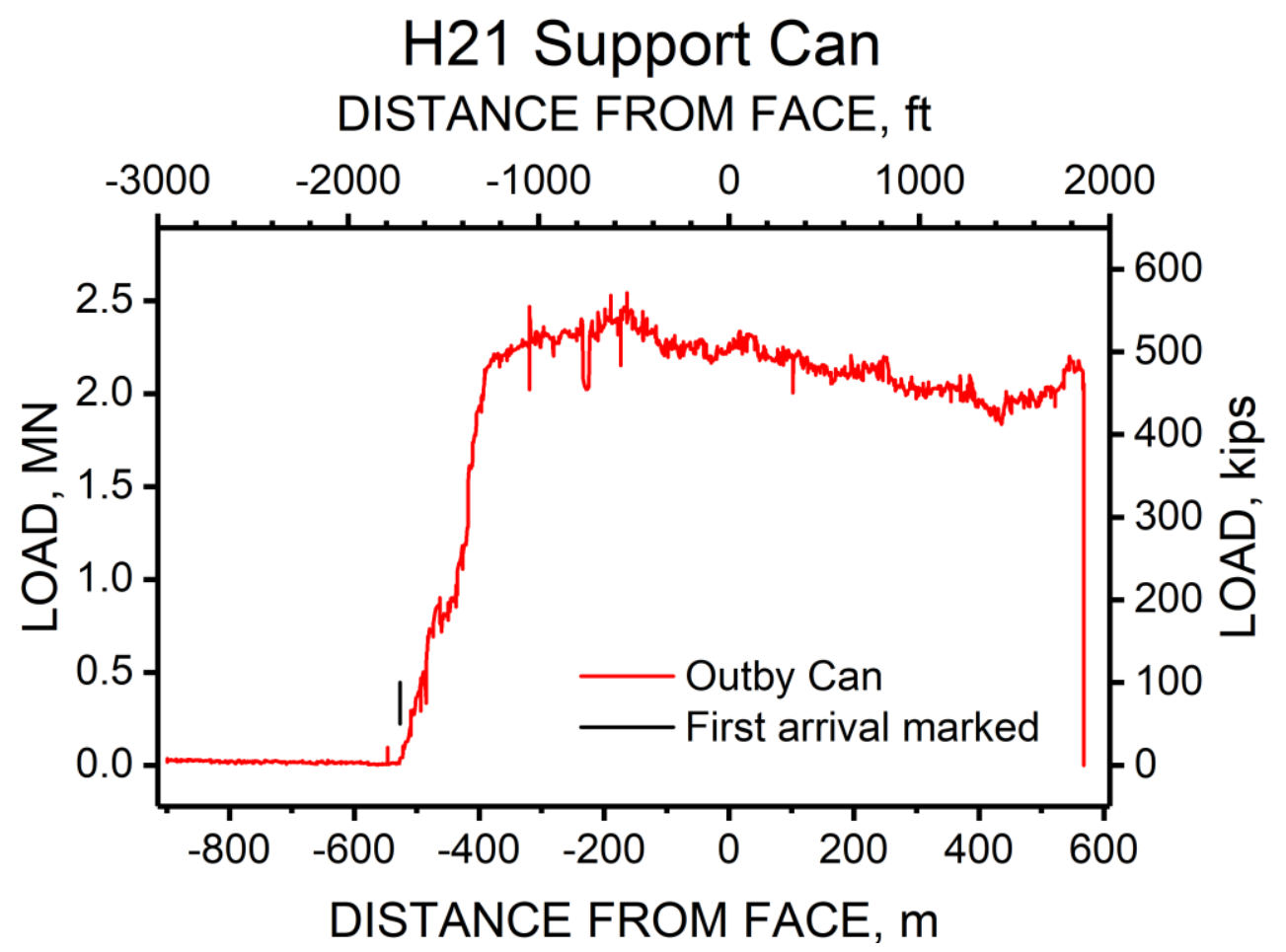

Figure 52. Load on outby support Can at $\mathrm{H} 21$ at Mine B, indicating the distance from face at which first arrival of mining-induced abutment stress was detected.

Table 14. Distance from face along gate road of first indication of arrival of abutment load at outby instrumented support Can at $\mathrm{H} 21$ station at Mine $\mathrm{B}$ and resulting distance to gob corner. This distance was determined by the method using the first sustained load increase above noise level

\begin{tabular}{c|c|c|c|c|c|c}
\hline $\begin{array}{c}\text { Support } \\
\text { Can }\end{array}$ & $\begin{array}{c}\text { Lateral } \\
\text { distance, } \mathbf{m}\end{array}$ & $\begin{array}{c}\text { Lateral } \\
\text { distance, } \mathbf{f t}\end{array}$ & $\begin{array}{c}\text { Distance } \\
\text { along } \\
\text { panel, } \mathbf{m}\end{array}$ & $\begin{array}{c}\text { Distance } \\
\text { along } \\
\text { panel, ft }\end{array}$ & $\begin{array}{c}\text { Distance to } \\
\text { gob corner, } \\
\mathbf{m}\end{array}$ & $\begin{array}{c}\text { Distance to } \\
\text { gob corner, } \\
\mathbf{f t}\end{array}$ \\
\hline $\mathrm{H} 21$ inby & 57.0 & 187 & 527.0 & $1,728.9$ & 530.0 & $1,739.0$ \\
\hline
\end{tabular}

Observed-Ground Condition Surveys

Mine $A$

Walking ground condition surveys were not taken at frequent enough intervals to be useful for determination of load transfer distance. However, at the two outby instrumentation sites, a few more ground condition surveys were taken so that bracketing load transfer distance was possible. Larson and Whyatt [2012] used a threshold to indicate arrival of the abutment load with this method, which was an increase in rating of 0.5 of any of the average roof, rib, or floor conditions for a site. Accordingly, considering Figures 33 and 34, the distance to the longwall face where the first indication of abutment load arrived can be bracketed. This is done by noting 
distances to the face from the survey site that correspond to the survey times just before and just after an increase was first noted in any of the floor, rib, or roof ratings. Unfortunately, infrequent surveys do not produce tight ranges, as can be seen by comparing the ranges in Table 15 . These ranges are added to the other instrument scatters in Figures 53 and 54. Considering the ranges shown in Table 15, the distance along the panel was likely in the lower part of the listed range in 1 North and in the upper part of the listed range in 2 North.

Table 15. Range indication when abutment load was sensed by observation with ground condition ratings at instrumented outby sites at Mine $A$

\begin{tabular}{|c|c|c|c|c|c|c} 
Site & $\begin{array}{c}\text { Entry 2 } \\
\text { offset } \\
\text { from } \\
\text { gob, } \mathbf{m}\end{array}$ & $\begin{array}{c}\text { Entry 2 } \\
\text { offset } \\
\text { from } \\
\text { gob, ft }\end{array}$ & $\begin{array}{c}\text { Distance } \\
\text { along panel to } \\
\text { face when } \\
\text { rating } \\
\text { threshold was } \\
\text { met, } \mathbf{m}\end{array}$ & $\begin{array}{c}\text { Distance } \\
\text { along panel to } \\
\text { face when } \\
\text { rating } \\
\text { threshold was } \\
\text { met, ft }\end{array}$ & $\begin{array}{c}\text { Net distance } \\
\text { to face from } \\
\text { site when } \\
\text { rating } \\
\text { threshold was } \\
\text { met, } \mathbf{~}\end{array}$ & $\begin{array}{c}\text { Net distance } \\
\text { to face from } \\
\text { site when } \\
\text { rating } \\
\text { threshold was } \\
\text { met ft }\end{array}$ \\
\hline 1 North & 25.3 & 83 & 291.1 to 520.6 & 955 to 1,708 & 292.2 to 521.2 & 958.6 to 1,710 \\
\hline 2 North & 54.9 & 180 & 39.0 to 261.5 & 128 to 858 & 67.3 to 267.2 & 220.9 to 876.7 \\
\hline
\end{tabular}

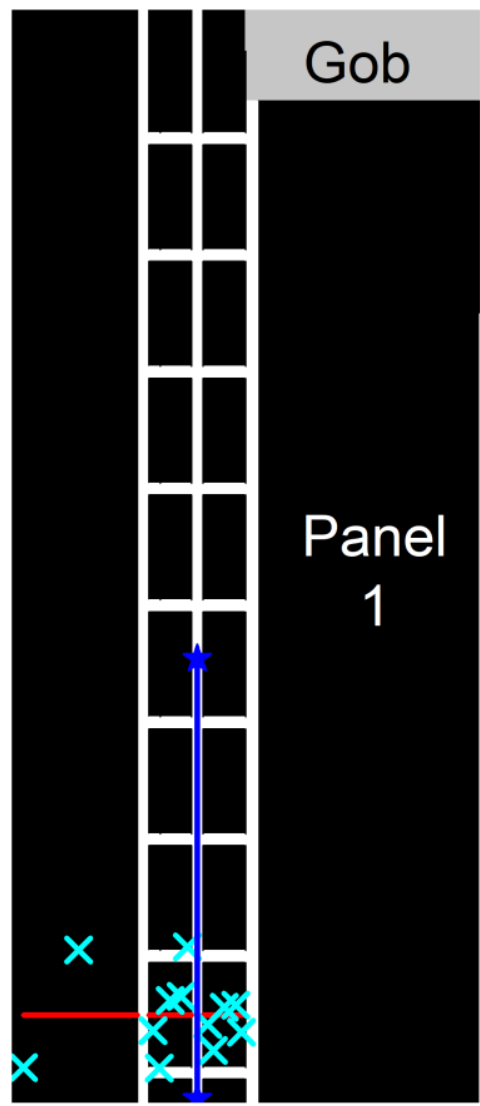

BPC drill holes

$X \quad B P C$ relative location at threshold

Range of location with ground condition rating

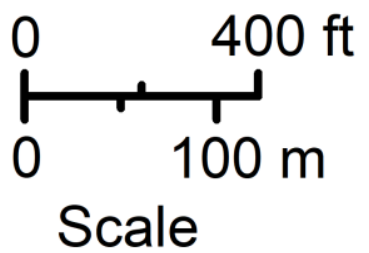

Figure 53. Relative range, with respect to the face within which a ground condition rating increased, indicating the arrival of abutment load in 1 North. These relative positions are superimposed on the gate road geometry with respect to the face,

where the face is shown at the average distance along the entries from the outby BPC drill holes when the stress-increase threshold was met at each BPC. 


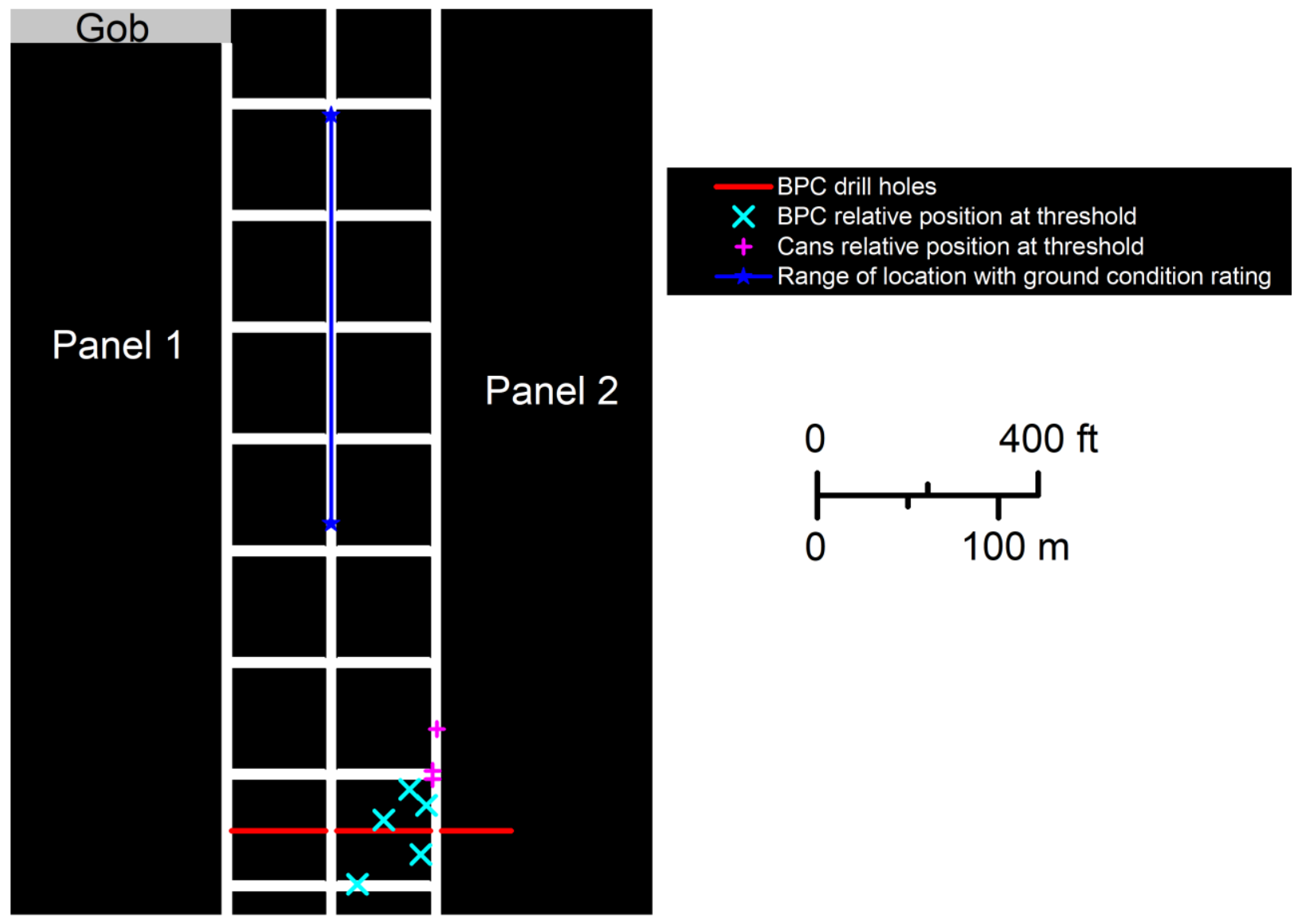

Figure 54. Relative range, with respect to the face within which a ground condition rating increased, indicating the arrival of abutment load in 2 North. These relative positions are superimposed on the gate road geometry with respect to the face, where the face is shown at the average distance along the entries from the outby BPC drill holes when the stress-increase threshold was met at each BPC.

\section{Entry and Can Closures}

Because a small number of support-Can-closure and entry-closure measurements were made at Mine A and a few more were made at Mine B, it is useful to explore whether this type of measurement is useful in providing some indication of load transfer distance over a larger area.

\section{Mine A}

Closure between anchor points on Cans - a string potentiometer anchored to wooden cap pieces at the top and high-tensile nylon fishing line extended from the potentiometer cable and attached to a screw near the Can's base-were measured on 10 instrumented support Cans in entry 3 of 2 North, as described earlier. Four Cans were instrumented in crosscut 10, and six were located about mid-pillar between crosscuts 9 and 10. Two roof-to-floor closure instrument sets were installed between Cans at the intersection and four were installed between Cans at midpillar, all in entry 3 (see Figure 19). All Cans, except A, C, and F, were previously eliminated from consideration in using Can-load increase as an indicator of first arrival of the mininginduced abutment stress. That fact influenced the choice to not use all Cans, with the exception 
of these same Cans (A, C, and F), for consideration in determining whether the attached closure meters might also be used to sense the first arrival of abutment stress.

In considering measurement of both Can and entry closures for such sensing, we must consider several points:

- Sensitivity of the potentiometer and datalogger - this helps establish a usable threshold to indicate first arrival of the abutment stress;

- Sufficient time to establish trends before arrival of the abutment stress, such as timedependent closure under static load, closure of gaps in the support Can assembly, etc.; and

- The ability of the spring system of the potentiometer to overcome friction and take up any closure displacement.

If sensitivity of the datalogger over its selected measuring range was the critical sensitivity issue, then the system should measure to the nearest $0.03566 \mathrm{~mm}(0.001404 \mathrm{in})$, which would provide sufficient sensitivity for the purpose of determining some measure of first arrival of the abutment stress. However, to be consistent with other instruments, the threshold for determining first arrival should be 10 times that, or $0.357 \mathrm{~mm}(0.014 \mathrm{in})$, just as the thresholds for BPCs and instrumented support Can loads were determined [Larson and Whyatt 2012]. It is expected that this threshold would need to be relative to an initial rate of closure determined while there is no influence from mining activity.

The issue of whether or not sufficient time has elapsed to establish static trends must be examined in plots of closure with face position, such as in Figures 55 and 56, because such plots would highlight effects resulting from mining. In this case, the 9-point-average smoothing technique was implemented. Without zooming in to the initial portions of the curves, it is hard to interpret whether trends are established, but the jagged nature of initial readings gives cause for question.

To address the ability of the spring system of the potentiometers to overcome friction and keep up with actual closure, a plot of closure rate, based on rate over eight samples apart (where there was a change in mining face position) is telling. Figure 57 shows a very jagged sampling of rates that are indicative of a spring that must continually overcome friction to take up slack on the cable wheel. During laboratory calibration, an applied tensile force of $4.4 \mathrm{~N}$ (16 oz) from the potentiometer spring seemed enough to overcome friction. However, Figure 57 shows that a stronger tensile force is needed when deployed in the field. Such instrumentation is not capable of precise indications of first arrival of abutment stress, but perhaps the measurements from these instruments might still be useful to correlate with arrival of a higher increase of abutment stress than do the BPCs and support Cans-just as the ground condition surveys are not as sensitive but may still be useful for indicating a change in load transfer distance.

To examine whether any of the closure data might be useful in determining first arrival of the abutment stress, the initial parts of the curves in Figures 55 and 56 and shown in Figures 58 and 59-again with the 9-point rolling average smoothing technique-were employed. These curves illustrate initial increased jaggedness that is likely the result of initial seating of the apparatus or increased friction of the take-up drum because of the potentiometer cable being pulled nearly to the end of its range - which portion of the curve must be ignored so that it is not considered part of the initial trend. Thereafter, it appears that certain closures show a relatively constant initial trend of roof sag, and that departure from that initial trend by a certain amount or threshold might be indicative of first arrival of abutment stress. Closures which show no roof sag were discarded. 
Those closures deemed worthy of analysis to determine first arrival of abutment stress were all entry closures, with the exception of the Can A closure at mid-pillar.

Figures 60 and 61 show the first part of the curves that were selected for analysis at the intersection and at mid-pillar, respectively. As mentioned earlier, these curves show some beginning jagged activity that should be ignored. For these curves, it was appropriate to establish an initial overall trend, which was assumed to be linear, and then monitor departure from that initial trend. A departure of $-0.357 \mathrm{~mm}$ (-0.014 in) from the initial trend was the threshold used to determine first arrival of the abutment stress.

Table 16 lists the results of distance from the gob (distance along entries and net distance) when the threshold was reached for indicating first arrival of abutment stress. The relative position of these distances with respective to the average location of the face when the threshold of the BPCs at the 2 North outby station were met are shown in Figure 62. This figure shows that closures were probably similar to ground condition surveys in their sensitivity of the first arrival of abutment stress.

\section{North closures in entry 3, crosscut 10} DISTANCE TO FACE, $\mathrm{ft}$

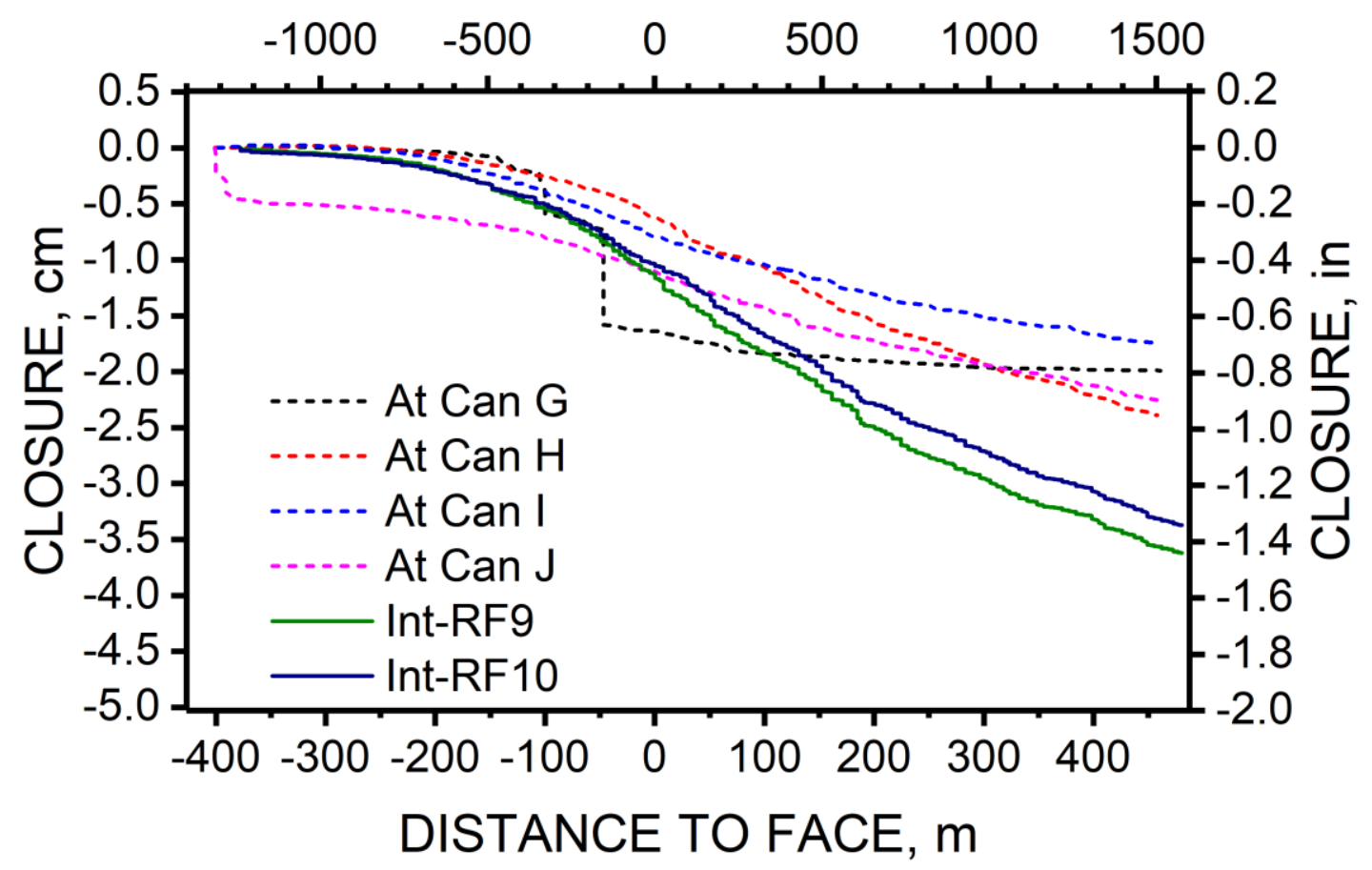

Figure 55. Closure at support Cans and at roof-to-floor measurement points in 2 North, entry 3, at crosscut 10 at Mine A. 
2 North closures in entry 3 , crosscuts 9 to 10 DISTANCE FROM FACE, $\mathrm{ft}$

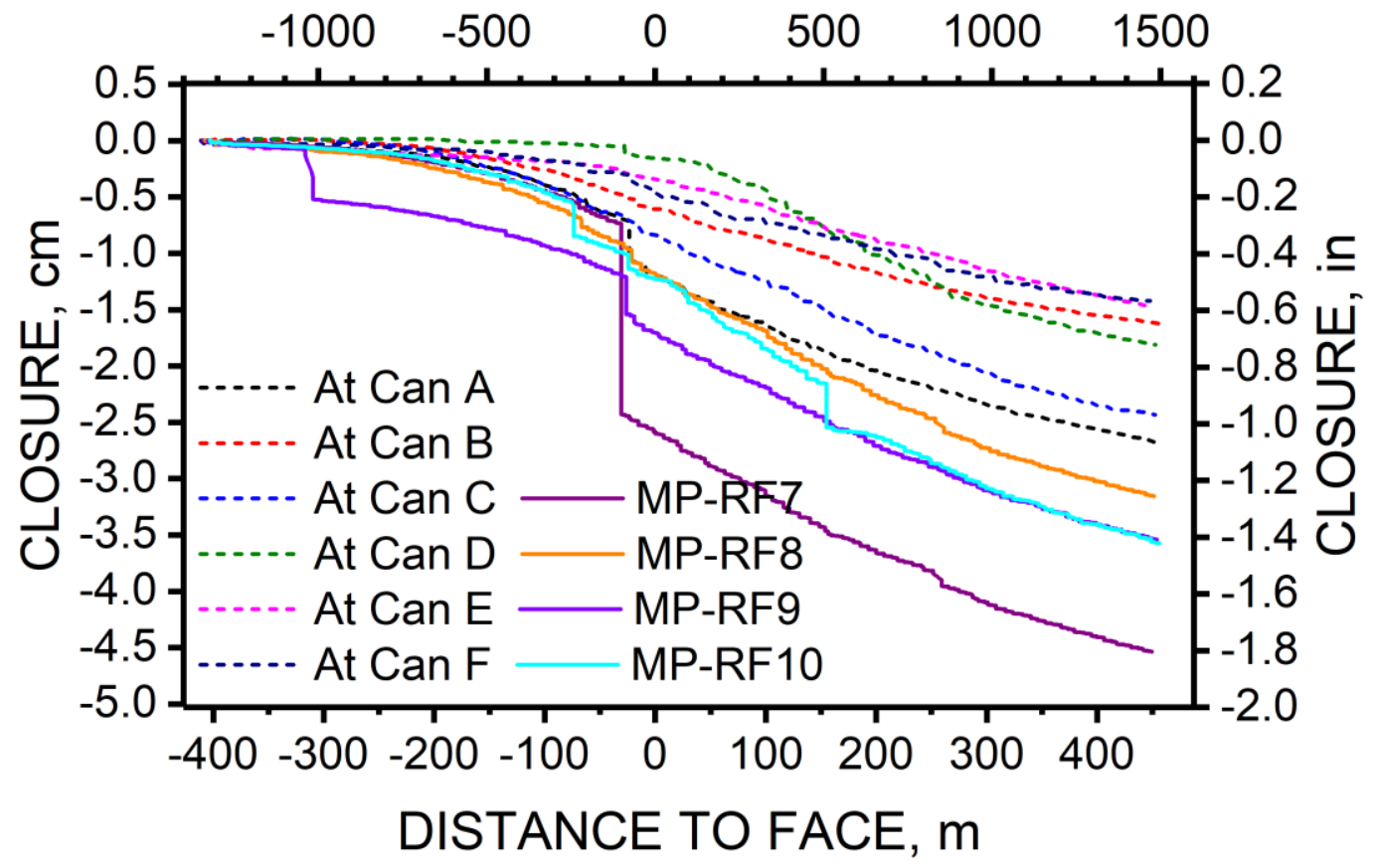

Figure 56. Closure at support Cans and at roof-to-floor measurement points in 2 North, entry 3, at mid-pillar between crosscuts 9 and 10 at Mine A.

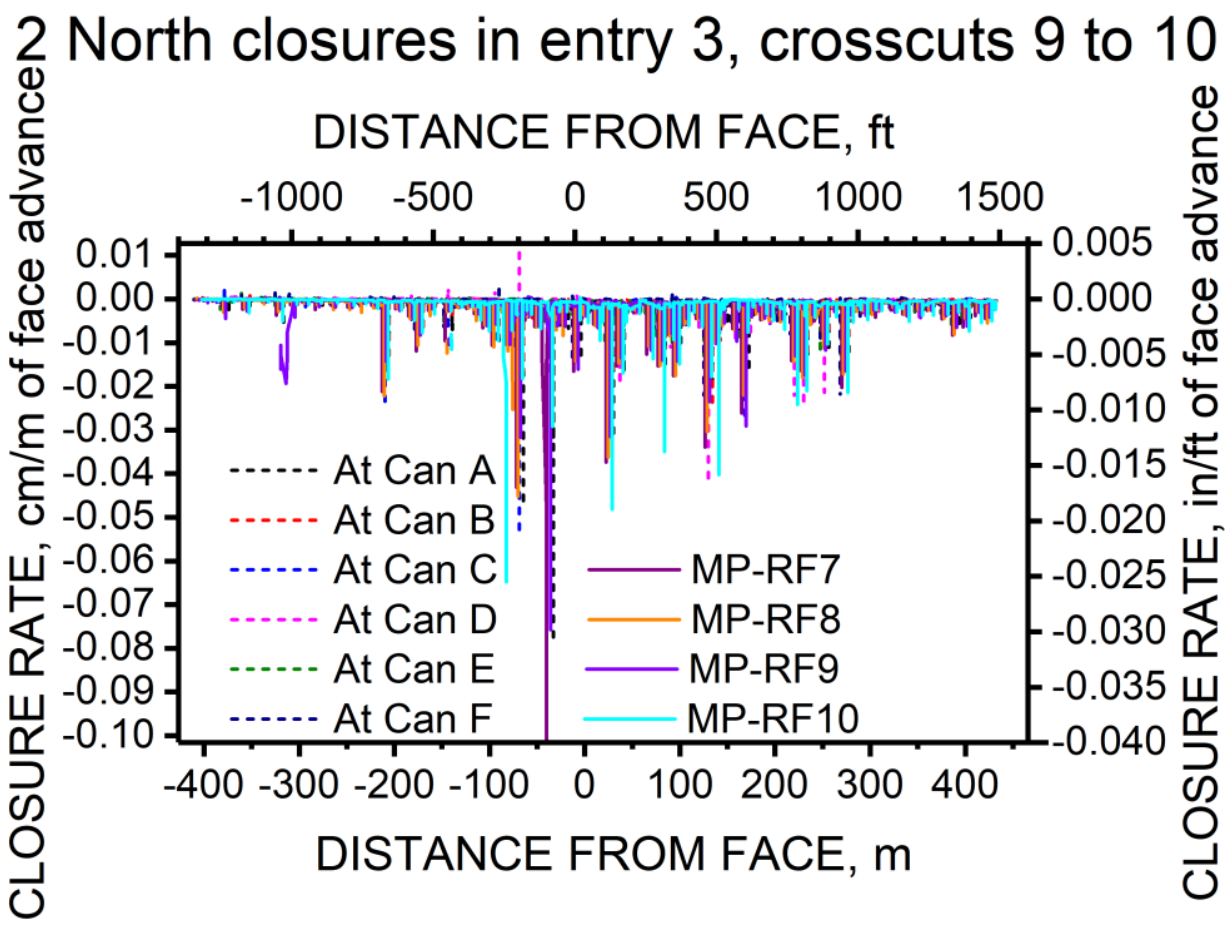

Figure 57. Closure rates at support Cans and at roof-to-floor measurement points in 2 North, entry 3, at mid-pillar between crosscuts 9 and 10 at Mine A. 
2 North closures in entry 3 , crosscut 10 DISTANCE TO FACE, $\mathrm{ft}$

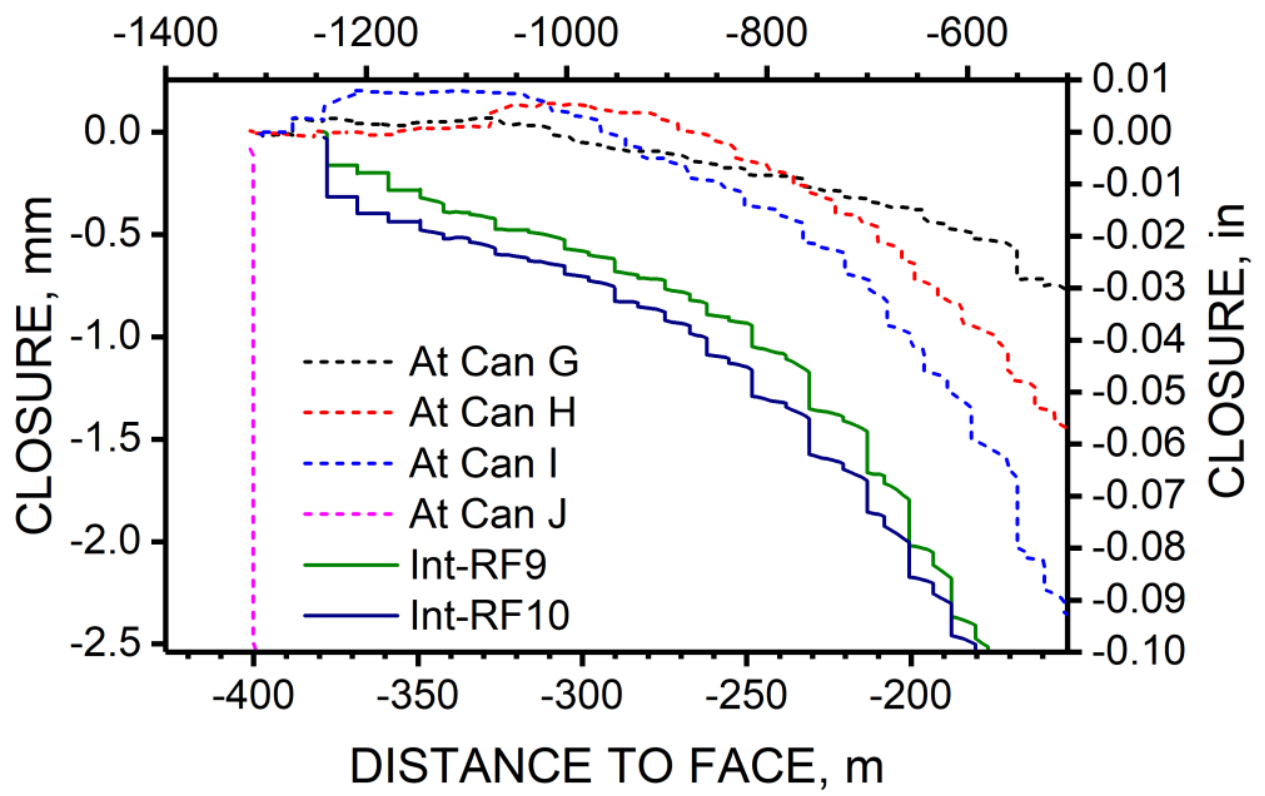

Figure 58. Zoomed-in view of initial closure at support Cans and at roof-to-floor measurement points in 2 North, entry 3, at crosscut 10 at Mine A.

2 North, entry 3 , between crosscuts 9 to 10 DISTANCE FROM FACE, $\mathrm{ft}$

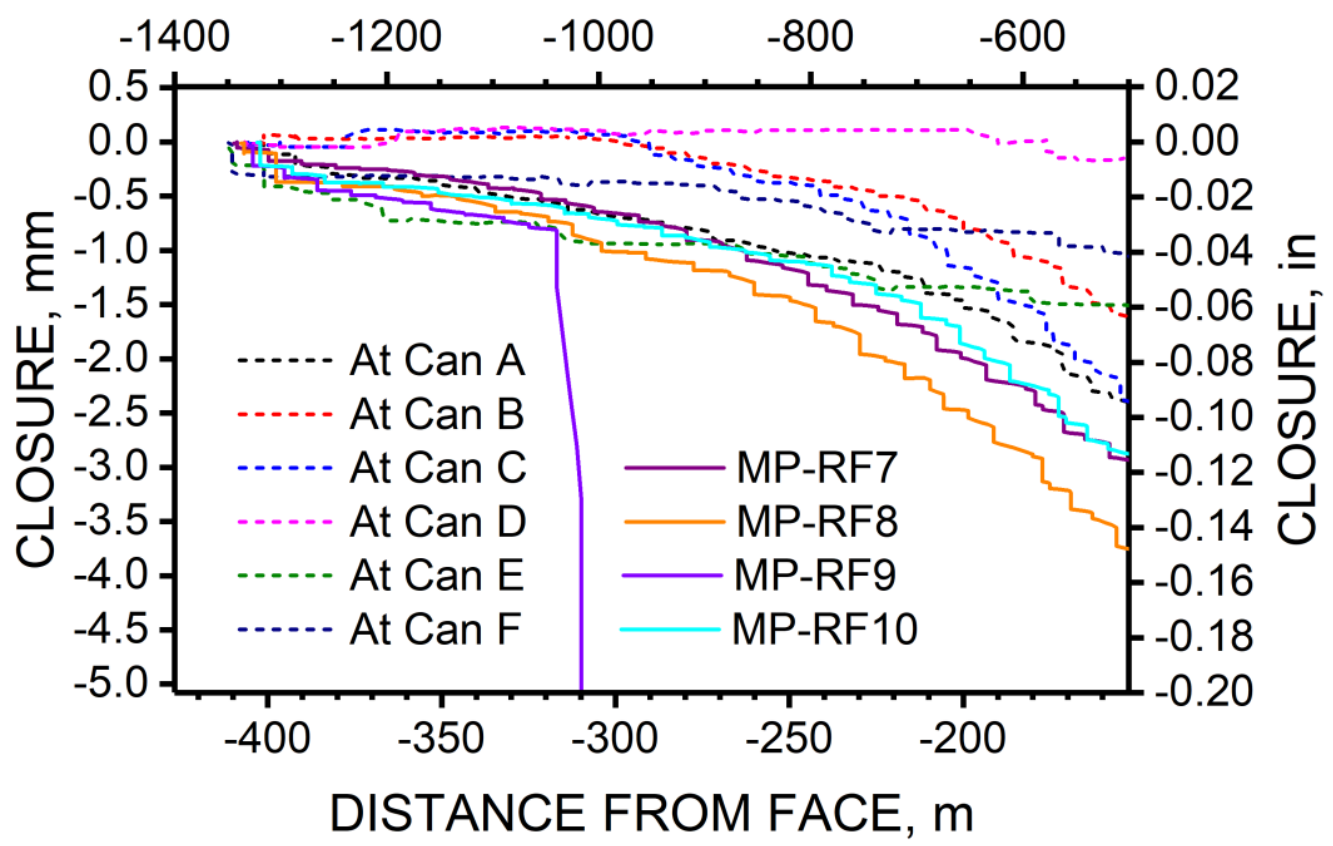

Figure 59. Zoomed-in view of initial closure at support Cans and at roof-to-floor measurement points in 2 North, entry 3, at mid-pillar between crosscuts 9 and 10 at Mine $A$. 
2 North closures in entry 3 , crosscut 10 DISTANCE FROM FACE, $\mathrm{ft}$

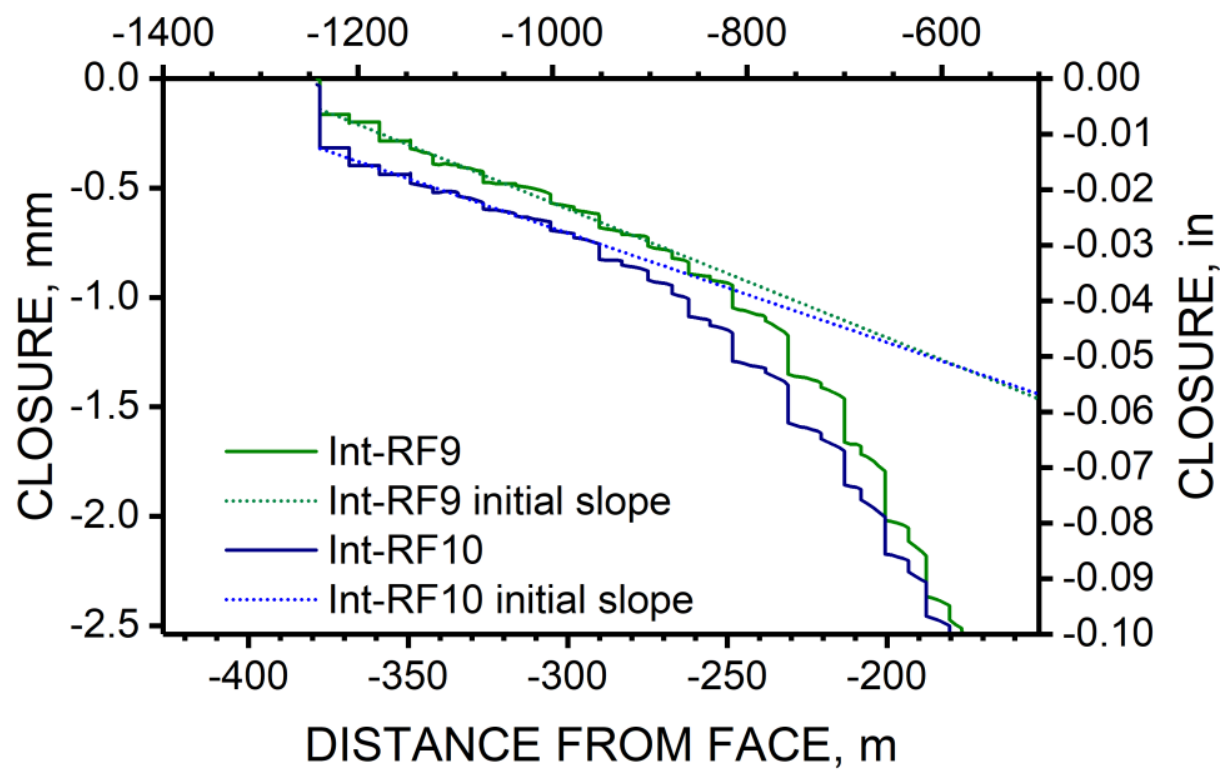

Figure 60. Initial part of select curves of Can and roof-to-floor closures versus face position at mid-pillar in entry 3 , at crosscut 10 in 2 North at Mine A. Fitted initial slopes of these curves are shown.

2 North, entry 3 , between crosscuts 9 to 10 DISTANCE FROM FACE, $\mathrm{ft}$

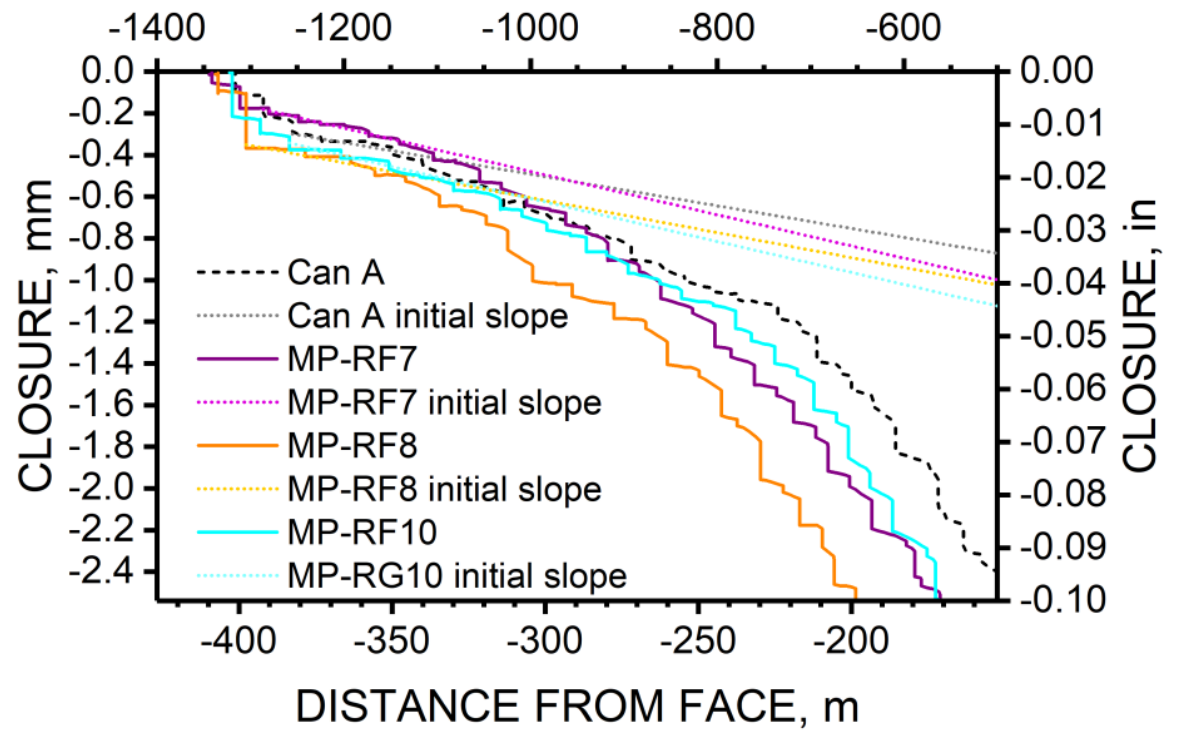

Figure 61. Initial part of select curves of Can and roof-to-floor closures versus face position at mid-pillar in entry 3, between crosscuts 9 and 10 in 2 North at Mine A. Fitted initial slopes of these curves are shown. 
Table 16. Distance from face along gate road of first indication of arrival of abutment stress at closure meters in entry 3 near the 2 North outby station and resulting distance to gob corner-method of $-2.54-\mathrm{mm}(-0.01-\mathrm{in})$ threshold departure from initial closure trend

\begin{tabular}{|c|c|c|c|c|c|c|}
\hline Instrument & $\begin{array}{l}\text { Offset } \\
\text { from gob, } \\
\text { m }\end{array}$ & $\begin{array}{l}\text { Offset } \\
\text { from gob, } \\
\text { ft }\end{array}$ & $\begin{array}{l}\text { Distance } \\
\text { along } \\
\text { panel } \\
\text { when } \\
\text { threshold } \\
\text { detected, } \\
m\end{array}$ & $\begin{array}{l}\text { Distance } \\
\text { along } \\
\text { panel } \\
\text { when } \\
\text { threshold } \\
\text { detected, } \\
\mathrm{ft}\end{array}$ & $\begin{array}{l}\text { Net } \\
\text { distance } \\
\text { to gob, } m\end{array}$ & $\begin{array}{l}\text { Net } \\
\text { distance } \\
\text { to gob, } \mathrm{ft}\end{array}$ \\
\hline Int-RF9 & 110.5 & 362.4 & 213.7 & 701.2 & 240.6 & 789.3 \\
\hline Int-RF10 & 113.3 & 371.8 & 231.0 & 758.0 & 257.3 & 844.3 \\
\hline Can A & 110.7 & 363.2 & 259.2 & \begin{tabular}{|l|l|}
850.2 \\
\end{tabular} & 281.8 & 924.6 \\
\hline $\begin{array}{l}\text { MP-RF7 } \\
\end{array}$ & 113.0 & 370.75 & 269.3 & \begin{tabular}{|l|l|}
883.4 \\
\end{tabular} & 292.0 & 958.0 \\
\hline MP-RF8 & 112.9 & 370.25 & 304.13 & \begin{tabular}{|l|l|}
997.6 \\
\end{tabular} & 324.3 & \begin{tabular}{|l|}
$1,064.1$ \\
\end{tabular} \\
\hline MP-RF10 & 112.9 & 370.5 & \begin{tabular}{|l|}
237.9 \\
\end{tabular} & \begin{tabular}{|l|l|}
780.4 \\
\end{tabular} & 263.3 & \begin{tabular}{|l|}
$1,03.9$ \\
\end{tabular} \\
\hline $\begin{array}{l}\text { Average } \\
\text { St. Dev }\end{array}$ & & & & & $\begin{array}{l}276.6 \\
29.6\end{array}$ & $\begin{array}{l}907.4 \\
97.2\end{array}$ \\
\hline
\end{tabular}
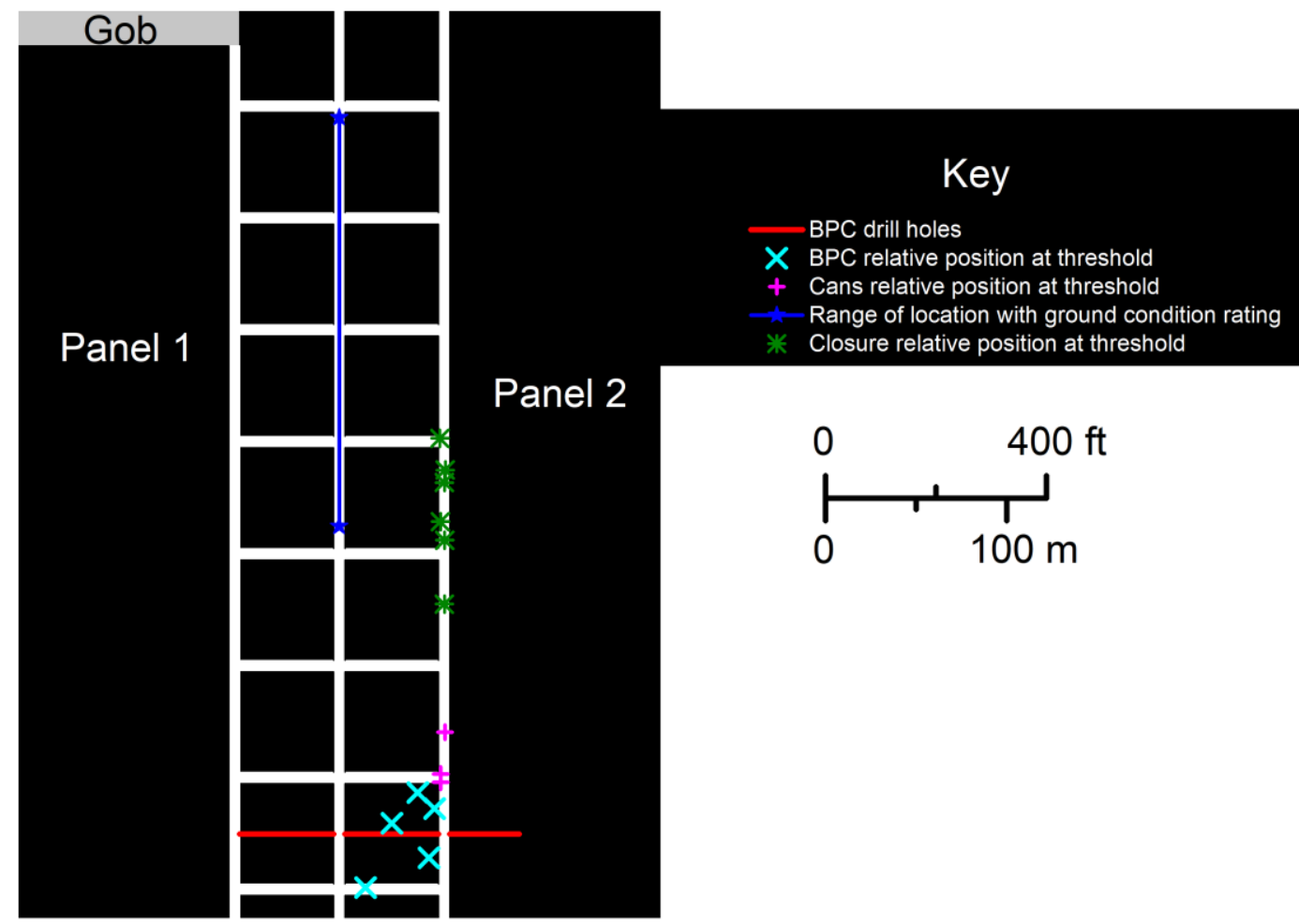

* Closure relative position at threshold

Figure 62. Relative position of BPCs, support Cans, range of ground condition, and closure meters in 2 North at Mine A when the threshold for first arrival of abutment stress was reached. These relative positions are superimposed in the gate road geometry with respect to the face, where the face is shown at the average distance along the entries

from the BPC drill holes when the stress-increase threshold was met at each BPC. 


\section{Mine $B$}

Four closure measurements were previously determined as candidates for determining distance at which the first arrival of mining-induced abutment load is detected (see Figure 40). The measurement curves were similar within a site-that is, within T34 or T20.

Given the variation in rate that is shown in Figure 40, the question arises as to the appropriate threshold for determining the distance from the face of first arrival of abutment stress. For example, at Mine A, 10 times the datalogger sensitivity was used as a threshold, or a closure of $0.03356 \mathrm{~cm}(0.014 \mathrm{in})$. At both T34 and T20 sites, 10 times the datalogger sensitivity was $0.003973 \mathrm{~cm}(0.001564 \mathrm{in})$. Because manufacturers are generally conservative about instrument sensitivity claims, a careful examination of the curves (smoothed by using the 9-point rolling average of measurements) and comparison with the initial trend help to determine the appropriate threshold. For consistency in our analyses, the lowest threshold considered should never be below 10 times the datalogger sensitivity.

Figures 63 and 64 show the measurement curves for the entry and Can closures of the inby T34 site. In addition, the initial section of the curve that was used for fitting an initial closure rate line is indicated along with the fitted initial trend line. Three distances are indicated at which a different threshold was reached. The distance indicated by the left mark is that determined by using 10 times the datalogger sensitivity. In these figures, a clear departure from the initial curve has begun. The right-most mark indicates the distance at which the same threshold used at Mine A was met. The distance to the face indicated by this larger threshold results in distances about $3 \%$ to $32 \%$ below the measurement range and about $18 \%$ below the average of distance to face measurements determined with closure measurements at Mine A. The lower depth of cover at Mine B should tend to reduce this distance with equal strata stiffness. Therefore, the distances at the common threshold appear to be compatible. However, if the sensitivity of dataloggers used at Mine B are better than the sensitivity of dataloggers used at Mine A, then the resulting determination of distance from the gob at first arrival of the abutment stress might be more in line with the distance of first arrival as measured with the BPC systems used at both mines. Table 17 summarizes the distances determined from these closure measurements using the two detection thresholds.

Figures 65 and 66 show closure curves of the Can roof to mid-height and entry at the T20 site at Mine B. The closure rates are significantly less than those at the T34 site. In this case, it appears that the string potentiometers may have exhibited cyclical sticking behavior. It appears that the initial trend was maintained in general, and these closure measurements were not sensitive to an increase in abutment stress as a result of mining.

The overall assessment of using datalogger-read closure measurements as indicators of first arrival of the mining-induced abutment load is not very good, in general. This is particularly true if sensors are spread out over many sites, with few per site. 
Table 17. Summary of distance to face and to gob corner when first arrival of mininginduced abutment stress was first detected, as determined with closure measurements with string potentiometers at T34 site at Mine B

\begin{tabular}{c|c|c|c|c|c|c|c|c}
\hline Instrument & $\begin{array}{c}\text { Offset } \\
\text { from } \\
\text { gob, } \mathrm{m}\end{array}$ & $\begin{array}{c}\text { Offset } \\
\text { from } \\
\text { gob, } \mathrm{ft}\end{array}$ & $\begin{array}{c}\text { Threshold } \\
\text { to detect } \\
\text { first arrival } \\
\text { of abutment } \\
\text { stress, cm }\end{array}$ & $\begin{array}{c}\text { Threshold } \\
\text { to detect } \\
\text { first arrival } \\
\text { of abutment } \\
\text { stress, in }\end{array}$ & $\begin{array}{c}\text { Distance } \\
\text { along entry } \\
\text { when } \\
\text { threshold } \\
\text { detected, } \mathrm{m}\end{array}$ & $\begin{array}{c}\text { Distance } \\
\text { along entry } \\
\text { when } \\
\text { threshold } \\
\text { detected, ft }\end{array}$ & $\begin{array}{c}\text { Net } \\
\text { distance } \\
\text { to gob, } \\
\text { m }\end{array}$ & $\begin{array}{c}\text { Net } \\
\text { distance } \\
\text { to gob, ft }\end{array}$ \\
\hline $\begin{array}{c}\text { T34 inby } \\
\text { entry }\end{array}$ & -1.4 & -4.5 & 0.03356 & 0.014 & 209.9 & 688.7 & 209.9 & 688.7 \\
\hline $\begin{array}{c}\text { T34 inby } \\
\text { entry }\end{array}$ & -1.4 & -4.5 & 0.003973 & 0.001564 & 289.8 & 950.7 & 289.8 & 950.7 \\
\hline $\begin{array}{c}\text { T34 inby } \\
\text { Can }\end{array}$ & -1.4 & -4.5 & 0.03356 & 0.014 & 207.3 & 680.0 & 207.3 & 680.0 \\
\hline $\begin{array}{c}\text { T34 inby } \\
\text { Can }\end{array}$ & -1.4 & -4.5 & 0.003973 & 0.001564 & 287.1 & 942.0 & 287.1 & 942.0 \\
\hline
\end{tabular}

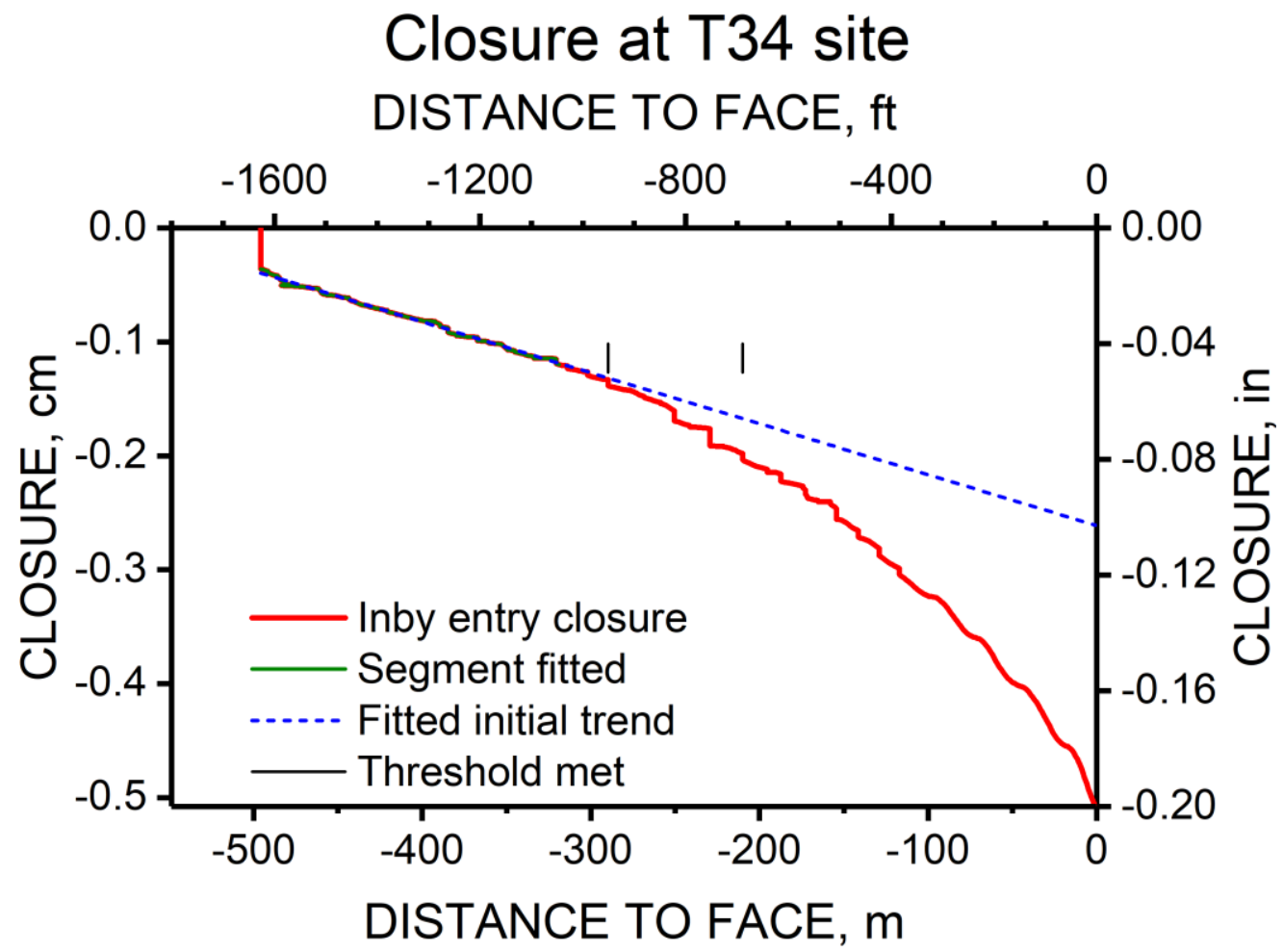

Figure 63. Closure of entry with distance to face at inby T34 site at Mine B. Measurements used for fitting a line to represent the initial closure rate are indicated. Fitted line used to represent the initial closure trend is shown. Black lines indicate where thresholds of departure from the fitted initial trend were met. Thresholds used are $-0.003973 \mathrm{~cm}$ $(-0.001564 \mathrm{in})$ on the left and $-0.03556 \mathrm{~cm}(-0.01400 \mathrm{in})$ on the right. 


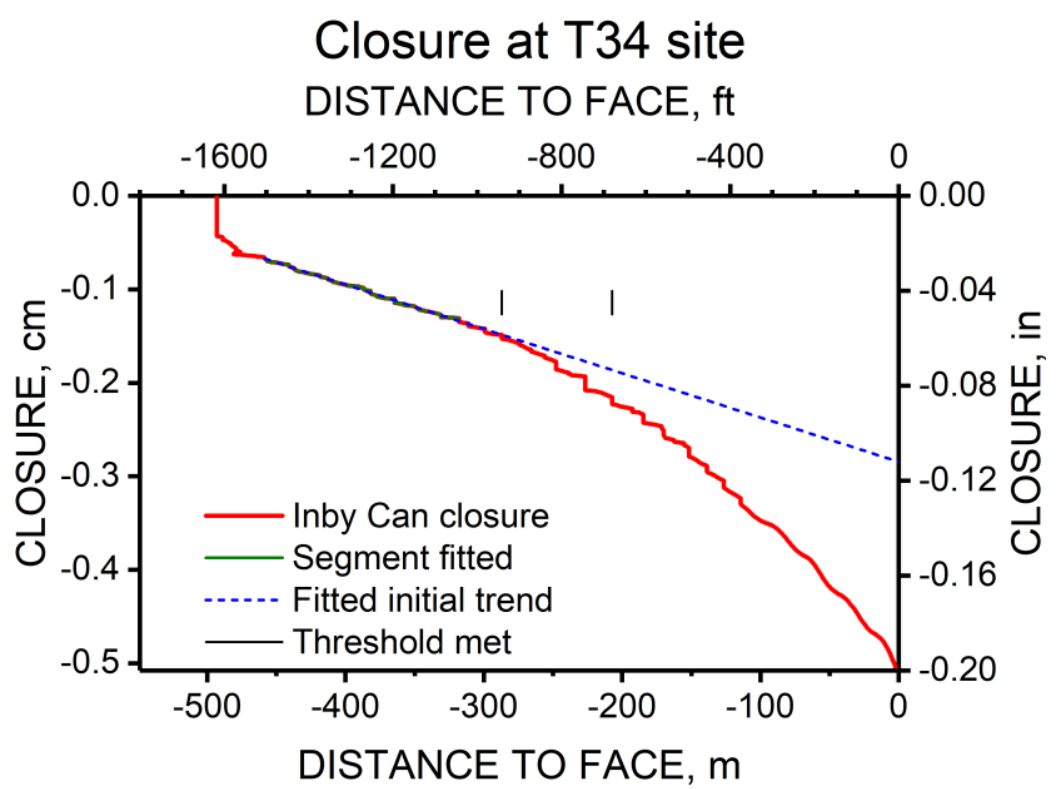

Figure 64. Closure of Can (roof to mid-height of Can) with distance to face at inby T34 site at Mine B. Measurements used for fitting a line to represent the initial closure rate are indicated. Fitted line used to represent the initial closure trend is shown. Black lines indicate where thresholds of departure from the fitted initial trend were met. Thresholds used are

$-0.003973 \mathrm{~cm}(-0.001564 \mathrm{in})$ on the left and $-0.03556 \mathrm{~cm}(-0.01400 \mathrm{in})$ on the right.

Closure at T20 site

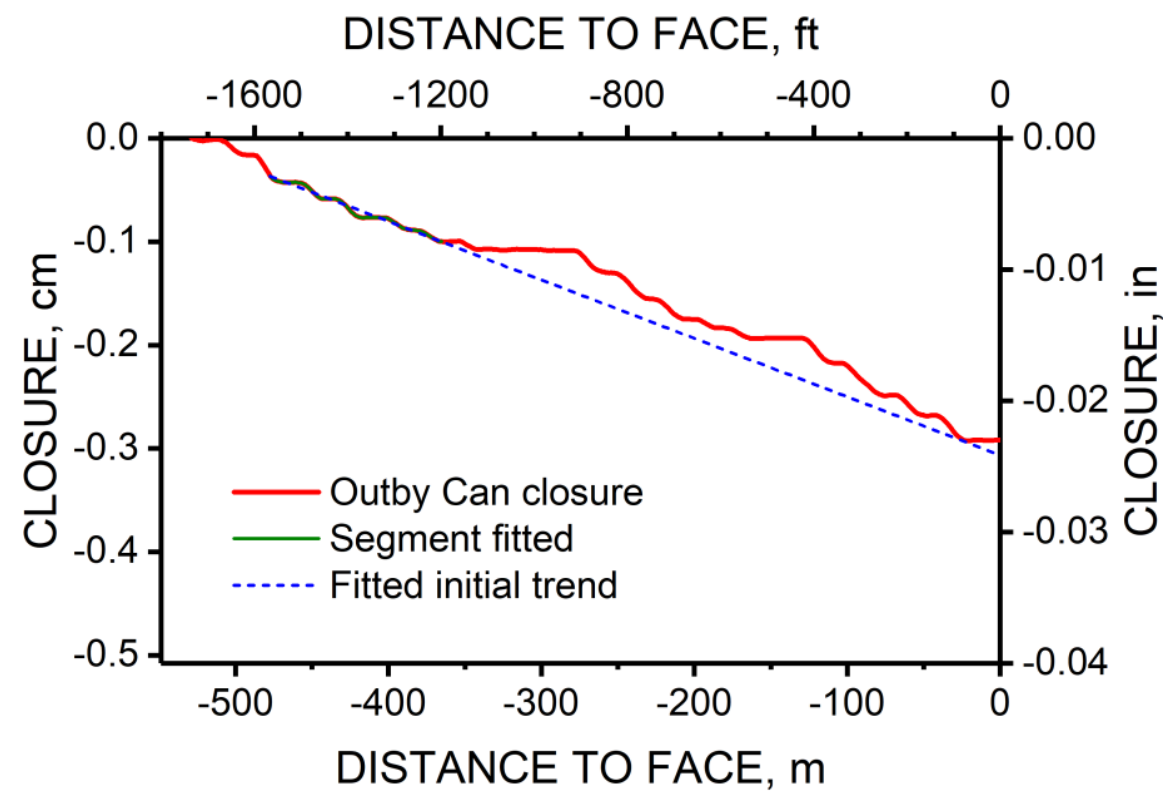

Figure 65. Closure of Can (roof to mid-height of Can) with distance to face at outby T20 site at Mine B. Measurements used for fitting a line to represent the initial closure rate are indicated. Fitted line used to represent the initial closure trend is shown. Horizontal jumps suggest periodic sticking of string pot. No departure from initial closure trend is apparent. 


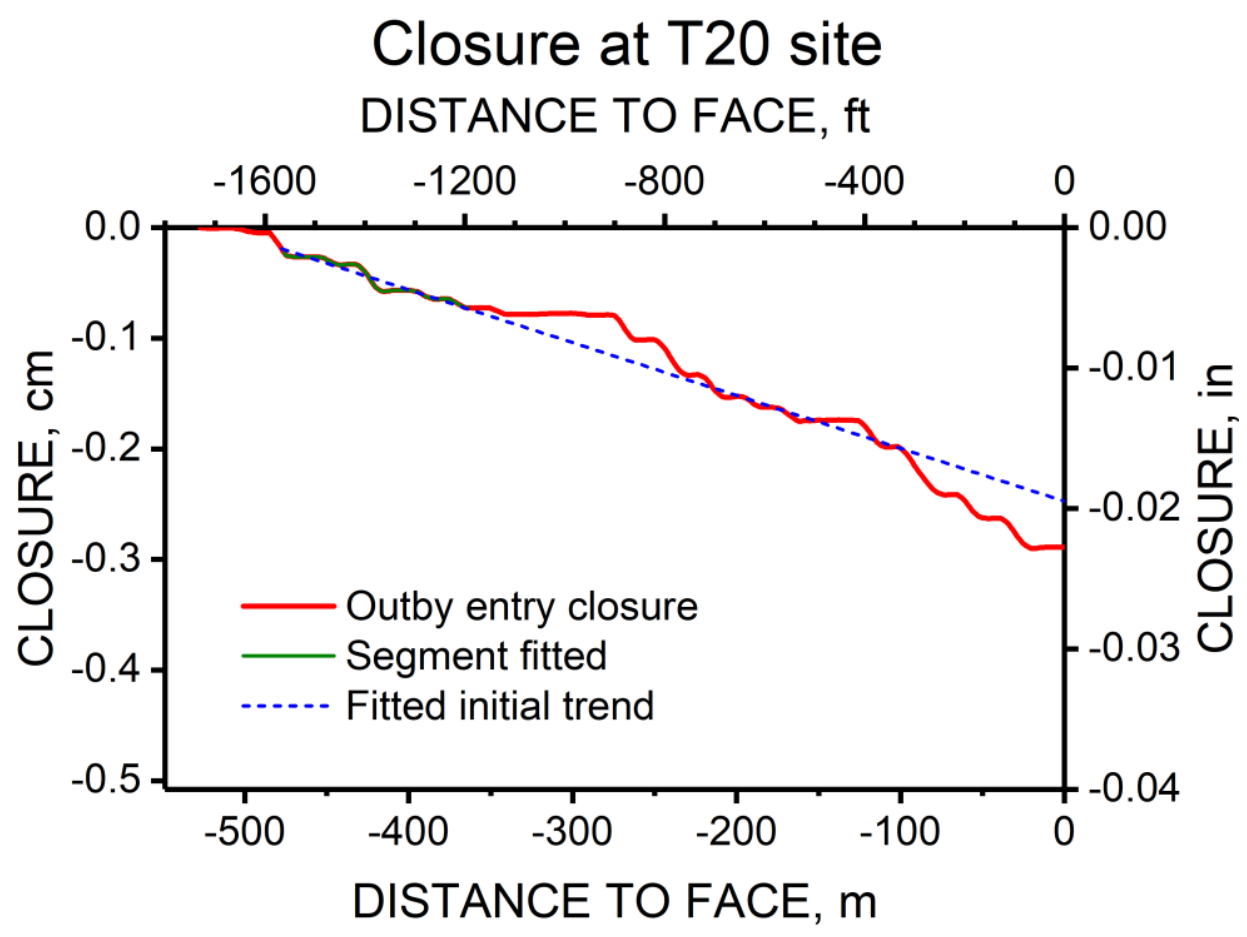

Figure 66. Closure of entry with distance to face at outby T20 site at Mine B. Measurements used for fitting a line to represent the initial closure rate are indicated. Fitted line used to represent the initial closure trend is shown. Horizontal jumps suggest periodic sticking of string pot. No departure from initial closure trend is apparent.

\section{Summary of First Detection of First Arrival of Mining-induced Abutment Stress}

Determination of first arrival of abutment stress is an important step toward determining load transfer distance (LTD). Such data must be converted via numerical techniques to an equivalent LTD, which subsequently can be used to calibrate numerical models to evaluate gate road layout design. The description below summarizes the determination of first arrival of mining-induced abutment stress from measurements and observations of various types.

At Mine A, the BPCs were most sensitive and most consistent in determining distance from the face at which the first arrival of mining-induced abutment stress is detected. However, problems with installation sometimes prevented pressurization of the BPCs or caused them to fail prematurely. Support Can load sensitivity to first arrival appeared to be highly dependent on the initial load induced at the time of installation (i.e., how tight the cribs and wedges were on top of the Can to reduce any void space in contacts). For entry closure measurements to be successful, a dense amount of such installations at a site are necessary because of the small fraction of successful measurement curves obtained from which distance at first arrival of abutment stress can be determined. Ground condition ratings, if done frequently, though less sensitive than other instrumentation, could be a candidate to provide a check concerning changing conditions (changing distance at first arrival of abutment stress) and suggest whether a model should be recalibrated for changing conditions. The large distance from the gob at which front abutment can be detected at Mine A suggests that load transfer distance is much higher than the calculated empirical load transfer distance (Equation 4). The equivalent load transfer distance 
still remains to be determined for each of the measurements. Such equivalent LTDs are determined by Larson et al. in Ground Stress in Mining Part 2 [NIOSH 2020].

The experiment at Mine B showed that great care must be taken to increase the probability of success. Even though the degree of failures was high, the limited number of successful determinations of first arrival of abutment stress suggests that the load transfer distance is also much higher than the calculated empirical load transfer distance. Table 18 shows measurements of distance from the cob corner to first arrival of mining-induced abutment stress and measurement ranges at Mine A. Table 19 shows the same for Mine B. The two tables show that the Mine B measurements are not incompatible with those of Mine A. The generally smaller amounts at Mine B are consistent for lesser cover of similar rock mass stiffness. The anomaly of very high distance determined with the load measured at the support Can in Mine B could have been the result of anomalous structure of the strata at that location.

Table 18. Summary of distance to gob corner at Mine A by instrument and location

\begin{tabular}{|c|c|c|c|c|c|c|c|c|}
\hline $\begin{array}{l}\text { Instrument and } \\
\text { location }\end{array}$ & $\begin{array}{c}\text { Average } \\
\text { distance to } \\
\text { gob } \\
\text { corner, } m\end{array}$ & $\begin{array}{c}\text { Std. dev. } \\
\text { of distance } \\
\text { to gob } \\
\text { corner, m }\end{array}$ & $\begin{array}{c}\text { Lower } \\
\text { range of } \\
\text { distance to } \\
\text { gob } \\
\text { corner, } m\end{array}$ & \begin{tabular}{|c|} 
Upper \\
range of \\
distance to \\
gob \\
corner, $m$ \\
\end{tabular} & $\begin{array}{c}\text { Average } \\
\text { distance to } \\
\text { gob } \\
\text { corner, ft }\end{array}$ & $\begin{array}{c}\text { Std. dev. } \\
\text { of distance } \\
\text { to gob } \\
\text { corner, ft }\end{array}$ & $\begin{array}{c}\text { Lower } \\
\text { range of } \\
\text { distance to } \\
\text { gob } \\
\text { corner, } \mathrm{ft}\end{array}$ & $\begin{array}{c}\text { Upper } \\
\text { range of } \\
\text { distance to } \\
\text { gob } \\
\text { corner, } \mathrm{ft}\end{array}$ \\
\hline BPCs, 1 North & 439.4 & 18.9 & 442.5 & 517.6 & $1,441.7$ & 62.0 & $1,451.8$ & $1,698.3$ \\
\hline BPCs, 2 North & 479.5 & 21.3 & 418.3 & 463.7 & $1,573.1$ & 70.0 & $1,372.5$ & $1,521.4$ \\
\hline $\begin{array}{c}\text { Support Cans, } 2 \\
\text { North }\end{array}$ & 406.2 & 13.7 & 390.6 & 416.2 & $1,332.5$ & 44.8 & $1,281.5$ & $1,365.4$ \\
\hline $\begin{array}{c}\text { Closures, } 2 \\
\text { North }\end{array}$ & 276.6 & 29.6 & 240.6 & 324.3 & 907.4 & 97.2 & 789.3 & $1,064.1$ \\
\hline $\begin{array}{c}\text { Ground } \\
\text { condition } \\
\text { surveys, } 1 \text { North }\end{array}$ & NA & NA & 292.2 & 521.2 & NA & NA & 958.6 & 1,710 \\
\hline $\begin{array}{c}\text { Ground } \\
\text { condition } \\
\text { surveys, } 2 \text { North }\end{array}$ & NA & NA & 67.3 & 267.2 & NA & NA & 220.9 & 876.7 \\
\hline \multicolumn{9}{|c|}{$\begin{array}{l}\text { NA = Not available } \\
\text { Std. dev. = Standard deviation } \\
\text { Note: Distance to gob refers to the distance between the location of the instrument or the location where the survey } \\
\text { assessment was taken and the nearest corner of the gob when the threshold for first arrival of mining-induced stress } \\
\text { was met. It is not the LTD. }\end{array}$} \\
\hline
\end{tabular}


Table 19. Summary of distance to gob corner at Mine B by instrument and location

\begin{tabular}{|c|c|c|c|c|c|c|c|c|}
\hline $\begin{array}{l}\text { Instrument and } \\
\text { location }\end{array}$ & $\begin{array}{c}\text { Average } \\
\text { distance to } \\
\text { gob } \\
\text { corner, } m\end{array}$ & $\begin{array}{c}\text { Std. dev. of } \\
\text { distance to } \\
\text { gob } \\
\text { corner, } m\end{array}$ & $\begin{array}{c}\text { Lower } \\
\text { range of } \\
\text { distance to } \\
\text { gob } \\
\text { corner, } \mathrm{m}\end{array}$ & $\begin{array}{c}\text { Upper } \\
\text { range of } \\
\text { distance to } \\
\text { gob } \\
\text { corner, } \mathrm{m}\end{array}$ & $\begin{array}{c}\text { Average } \\
\text { distance to } \\
\text { gob } \\
\text { corner, ft }\end{array}$ & $\begin{array}{c}\text { Std. dev. of } \\
\text { distance to } \\
\text { gob } \\
\text { corner, ft }\end{array}$ & $\begin{array}{c}\text { Lower } \\
\text { range of } \\
\text { distance to } \\
\text { gob } \\
\text { corner, } \mathrm{ft}\end{array}$ & $\begin{array}{c}\text { Upper } \\
\text { range of } \\
\text { distance to } \\
\text { gob } \\
\text { corner, } \mathrm{ft}\end{array}$ \\
\hline BPCs, & & $\sqrt{N A}$ & & & - & TIV & & 1,309 \\
\hline BPC, 2 North & & NA & 183.5 & & & N & & \\
\hline $\begin{array}{c}\text { Support Cans, } 2 \\
\text { North }\end{array}$ & 530 & NA & NA & NA & 1739 & NA & NA & NA \\
\hline $\begin{array}{c}\text { Closures, } 2 \\
\text { North }\end{array}$ & NA & NA & 207.3 & 289.8 & NA & NA & 680 & 950.7 \\
\hline \multicolumn{9}{|c|}{$\begin{array}{l}\text { VA = Not available } \\
\text { Std. dev. = Standard deviation } \\
\text { Note: Distance to gob refers to the distance between the location of the instrument or the location where the survey } \\
\text { issessment was taken and the nearest corner of the gob when the threshold for first arrival of mining-induced stress } \\
\text { vas met. It is not the LTD. }\end{array}$} \\
\hline
\end{tabular}

\section{Conclusions and Recommendations}

The data set presented in this report (Part 1) is important because it sets a standard for determination of first arrival of mining-induced stress increase. The Ground Stress in Mining Part 2 report [NIOSH 2020] demonstrates a way to convert first arrival measurements to equivalent LTD on the side of the panel, consistent with the Peng and Chiang [1984] equation (see Equation 2). LTD is very important to determine for a site so that numerical models might be calibrated and subsequently used for evaluation of mine layout design. The ultimate goal of the research is to enable better use of such tools so that safer designs are used for mine layout and accidents and fatalities are prevented. To that end, because of different sensitivities of instrumentation and methods and the varying degrees of difficulties associated with using each one, it is important to determine the best methods and practices for determining first arrival of abutment stress.

The BPCs, though they required the most work and care to install, had the capability to provide the best quality measurements of all of the instruments used and to be the most sensitive and consistent in detecting load transfer distance. Moreover, they provided information about the behavior of the pillars. Although the measurements taken at Mine A emphasize this conclusion, the lesser-quality measurements at Mine B do not weaken this conclusion. Instead, they emphasize the need to use new hydraulic connections and to drill in such a manner to ensure good quality boreholes. Moreover, though not covered in this report (see Ground Stress in Mining Part 2 [NIOSH 2020]), BPCs can help provide information that is useful in determining the coal strength model. BPCs that are pre-cast in grout can pose installation difficulties in some coal, as demonstrated particularly at the 2 North outby site. However, the experience at Mine B does not provide a fair evaluation of using flatjacks that are plunged and oriented in a grout-filled borehole. The experience at Mine B suggests significant problems were caused by methods used for installation and initial faulty hydraulic parts. Therefore, installation efforts must ensure a smooth borehole that dips downward enough to ensure grout placement.

Instrumented support Cans have the potential to be useful in determining first arrival of mining-induced abutment stress, but the chances of success depend greatly on the initial 
tightness of the top cribbing and wedges. To better ensure quality installation, perhaps monitoring of the load on a Can should start before the cribbing and wedges are installed, and a threshold initial load could be established that might increase the chance of success in determining first arrival of mining-induced abutment stress.

Overall, using string potentiometers to measure closures for the purpose of determining distance to first arrival of mining-induced abutment stress was very problematic and did not yield a high degree of success. Moreover, the sensing device must be improved. Even so, the closure rates seemed to vary by location. This fact is probably representative of differences in structure above or below the seam. If such a method is used for detecting first arrival of abutment stress because of ease of installation, then the instruments should be installed at sufficient density to increase chances of success from among the installations, and the instruments installed should have higher string tensions than those used in this research, which were $4.4 \mathrm{~N} \mathrm{(16} \mathrm{oz).}$

Ground condition surveys, when used, must be conducted frequently-e.g., at least two or three times per week in all accessible gate roads. The results at Mine A in this study suggest that this method is less sensitive than instrumentation, but it is easily conducted with little expense and with a moderate amount of personnel time while gate roads are actively used. Local variation in distance to detection of first arrival of abutment stress might be indicated with frequent walking surveys. Moreover, baseline results of such surveys may be indicative of changes in offseam structure. The degree of usefulness of the surveys in this regard must be tested with more case studies. The ratings system may need slight modification for a given mine or seam.

It is recommended that MIDAS datalogger software be modified to help prevent writing over previous data during the downloading operation. Excellent familiarity with the datalogger is recommended to prevent problems such as incorrect wiring and overwriting of data.

Using these recommendations will increase the quality of measurements of first arrival of mining-induced abutment stress, and subsequently, provide better quality determinations of LTD. The effort involved in conducting measurements with BPCs or instrumented support Cans along with ground condition surveys is high in terms of instrument costs, drilling costs (for BPCs and extensometers), data acquisition and setup, data analysis, and personnel costs. The installations described in this report were monumental efforts. If a mining operator were to consider using measurements and observations to calibrate numerical models, it is highly useful to obtain information about first arrival of abutment stresses with more sensitive instruments. Doing so often gains information about behavior of the coal pillar. At the same time, establishing relative sensitivity by determining first arrival of abutment stress with ground condition surveys is important. Once the more sensitive measurements have been made, it is possible to reduce subsequent costs to those required to conduct ground condition surveys to assess changes in calibration. Such costs are not difficult to justify when conditions depart drastically from the empirical assumptions, and when better assessment of conditions is needed to evaluate failure mechanisms not explained by empirical methods. 


\section{Acknowledgments}

The cooperative efforts of the operators of Mine A and Mine B were excellent and are gratefully acknowledged. NIOSH coworkers Craig Compton, Dennis Dolinar, David Oyler, and Brad Seymour assisted with installation of the instruments. Support Can bladder calibrations were accomplished by David Gearhart and Tim Batchler. Michael Stepan assisted with string potentiometer calibrations. Personnel from Agapito and Associates designed the instrumentation plan, drilled BPC holes, and installed BPCs at Mine A. Mine laborers drilled extensometer holes at Mine A. Mine engineers and aforementioned NIOSH personnel drilled all holes and installed instrumentation at Mine B. Engineers at both mines maintained the data systems and retrieved datalogger modules. All of these efforts made this study possible and are gratefully appreciated. 


\section{References}

Abel JF, Jr. [1988]. Soft rock pillars. Int. J. Min. Geol. Eng., Vol. 6, pp. 215-248.

Agapito JFT, Gilbride L, Koontz W [2005]. Implication of highly anisotropic horizontal stresses on entry stability at the West Elk Mine, Somerset, Colorado. In: Peng SS et al. eds. Proceedings: 24th International Conference on Ground Control in Mining. (Morgantown, WV: August 2-4, 2005) Morgantown, WV: West Virginia University, pp. 196-202.

Australian Coal Association Research Program [2014]. Outburst: Prediction: Geology. University of Wollongong, <http://www.undergroundcoal.com.au/outburst/prediction_geology.aspx $>$ [Accessed 3/26/2014].

Barron K, Pen Y [1992]. A revised model for coal pillars. In: Iannacchione AT et al. eds. Bureau of Mines Information Circular 9315, Proceedings of the Workshop on Coal Pillar Mechanics and Design.U.S. Department of the Interior, pp. 144-157.

Bieniawski ZT [1981]. Improved design of coal pillars for U.S. mining conditions. In: Peng SS ed., Proceedings: 1st Conference on Ground Control in Mining. (Morgantown, WV: July 27-29, 1981) Morgantown, WV: West Virginia University, pp. 13-22.

Bieniawski ZT, Van Heerden WL [1975]. The significance of in situ tests on large rock specimens. Int. J. Rock Mech. Min. Sci. \& Geomech. Abstr. Vol. 12, No. 4, pp. 101-113.

Carroll CJ [2003]. Fractures in the Mesaverde Group at Somerset Coal Field, Delta and Gunnison Counties, Colorado, Ch. 11, In: Piceance basin guidebook, Denver, CO: Rocky Mountain Association of Geologists, pp. 194-207.

Eakins W, Tremain-Ambrose CM, Phillips RC, Morgan ML [1998]. Demonstrated reserve base for coal in Colorado: Somerset Coal Field. Colorado Geological Survey Open-File Report 98-5, $32 \mathrm{pp}$.

Fiscor S [1994]. ARCO Coal's West Elk Mine. Coal Age, Vol. 99, No. 5, pp. 46-48.

Gadde MM, Peng SS [2009]. Weak floor stability during perimeter mining in the Illinois Basin coal mines. In: Barczak T et al. eds. Proceedings: 28th International Conference on Ground Control in Mining. (Morgantown, WV: July 28-30, 2009) Morgantown, WV: West Virginia University, pp. 223-232.

Gaddy FL [1956]. A study of the ultimate strength of coal as related to the absolute size of the cubical specimens tested. Bulletin of the Virginia Polytechnic Institute, Engineering Experiment Station Series No. 112. Vol. 49, No. 10, Blacksburg, VA: Virginia Polytechnic Institute, 27 pp.

Goodrich RR, Agapito JFT, Pollastro C, LaFrentz L, Fleck K [1999]. Long load transfer distances at the Deer Creek Mine. In: Amadei B et al. eds. Rock Mechanics for Industry, Proceedings of the 37th U.S. Rock Mechanics Symposium. (Vail, Colorado: June 6-9, 1999) Rotterdam: A.A. Balkema, pp. 517-523.

Harris R, Luthi A, Mayo AL, Koontz W [2002]. Structural control of hydrodynamic anisotropy in the West Elk Mine region, western Colorado. Environmental \& Engineering Geoscience, Vol. VIII, No. 4, pp. 309-318. 
Harvey S, Ozbay U, Neugebauer E, Koontz W, Anderson T, Warfleid B, Avery J [2009]. In-situ testing of Roofex yielding rock bolts in coal ribs. In: Barczak T et al. eds. Proceedings: 28th International Conference on Ground Control in Mining. (Morgantown, WV: July 28-30, 2009) Morgantown, WV: West Virginia University, pp. 181-186.

Heasley KA [1998]. Numerical modeling of coal mines with a laminated displacementdiscontinuity code. Ph.D. Dissertation. Golden, Colorado: Colorado School of Mines, 205 pp. Heasley KA [2010]. LaModel, ver. 3.0, Morgantown, WV: West Virginia University. Holland CT [1964]. The strength of coal in mine pillars. In: Spokes EM, Christiansen CR eds. Proceedings of the Sixth Symposium on Rock Mechanics. (Rolla, MO: October 1964) Rolla, MO: University of Missouri at Rolla, pp. 450-466.

Hooker VE, Leighton F, Steblay BJ [1974]. Microseismic investigations in coal mines. In: Proceeding: American Mining Congress Coal Convention. Article, (Pittsburgh, PA: May 5-8, 1974) Washington, D.C.: American Mining Congress.

Hustrulid WA [1976]. A review of coal pillar strength formulas. Rock Mech., Vol. 8, No. 2, pp. $115-145$.

Itasca Consulting Group [2011]. FLAC: Fast Lagrangian analysis of continua-user's guide (version 7.0), $384 \mathrm{pp}$.

Itasca Consulting Group [2013]. FLAC3D_Fast Lagrangian analysis of continua in 3 dimensions: User's guide, version 5.01, Minneapolis: Itasca Consulting Group, Inc., 350 pp.

Jones TH [2012]. Knowledge is power: Introducing the MIDAS, a new permissible datalogging system for use in mines. In: Barczak T et al. eds. Proceedings: 31st International Conference on Ground Control in Mining. (Morgantown, WV: July 31-August 2, 2012) Morgantown, WV: West Virginia University, pp. 245-250.

King HJ, Whittaker BN [1970]. A review of current knowledge on roadway behaviour, especially the problems on which further information is required. In: Proceedings of the Symposium on Roadway Strata Control in Roadways. (Nottingham, U.K.: April 16, 1970) London: The Institution of Mining Engineers, pp. 73-87.

Larson MK, Lawson HE, Tesarik DR [2015]. Load transfer distance measurements at two mines in the western U.S. In: Barczak TM et al. eds. Proceedings of the 34th International Conference on Ground Control in Mining. (Morgantown: July 28-30, 2015) Morgantown, WV: West Virginia University, pp. 54-64.

Larson MK, Whyatt JK [2009]. Deep coal longwall panel design for strong strata: The influence of software choice on results. In: Esterhuizen GS et al. eds. NIOSH Information Circular 9512, Proceedings of the International Workshop on Numerical Modeling for Underground Mine Excavation Design. (Asheville, NC: June 28, 2009) Pittsburgh, PA: U.S. Department of Health and Human Services, pp. 75-87.

Larson MK, Whyatt JK [2012]. Load transfer distance calibration of a coal panel scale model: A case study. In: Barczak T et al. eds. Proceedings of the 31st International Conference on Ground Control in Mining. (Morgantown, WV: July 31-August 2, 2012) Morgantown, WV: West Virginia University, pp. 195-205. 
Larson MK, Whyatt JK [2013]. Panel-scale modeling of a deep longwall panel: The MULSIM alternative. In: Barczak T et al. eds. Proceedings: 32nd International Conference on Ground Control in Mining. (Morgantown, WV: July 30-August 1, 2013) Morgantown, WV: West Virginia University, pp. 181-188.

Lawson H, Zahl E, Whyatt J [2012]. Ground condition mapping: A case study. In: 2012 SME Annual Meeting, "Mine to Market: Now It's Global" Preprint 12-122, (Seattle, WA: Feb 19-22, 2012) Englewood, CO: Society for Mining, Metallurgy, and Exploration, Inc., 7 pp.

Lawson HE, Whyatt J, Larson M [2013]. Investigation of pillar loading considerations in determination of pillar stability factors for longwall gateroad design. In: Barczak T et al. eds. Proceedings, 32nd International Conference on Ground Control in Mining. (Morgantown, WV: July 30-August 1, 2013) Morgantown, WV: West Virginia University, pp. 28-37.

Leighton F, Steblay BJ [1976]. Coal mine bounce and roof fall research. In: F, First Symposium on Underground Mining at National Coal Association/Bituminous Coal Research Coal Conference and Expo 2. Article, (Louisville, KY: October 21-23, 1975), pp. 104-119.

Lucas JR, Adler L, (coordinating eds.) [1973]. Roof and ground control, Ch. 13, In: SME mining engineering handbook, 1st ed., ed. by Cummins AB, Given IA, New York: Society of Mining Engineers of The American Institute of Mining, Metallurgical, and Petroleum Engineers, Inc., pp. 1-196.

Mark C [1987]. Analysis of longwall pillar stability. Ph.D. Thesis. University Park, PA: The Pennsylvania State University, $441 \mathrm{pp}$.

Mark C [2009]. Deep cover pillar recovery in the U.S. In: Peng SS et al. eds. Proceedings: 28th International Conference on Ground Control in Mining. (Morgantown, WV: July 28-30, 2009) Morgantown, WV: West Virginia University, pp. 1-9.

Mark C, Chase FE [1997]. Analysis of Retreat Mining Pillar Stability (ARMPS). In: Mark C, Tuchman RJ eds. Proceedings: New Technology for Ground Control in Retreat Mining, DHHS (NIOSH) Publication No. 97-133, IC 9446. Pittsburgh, PA: National Institute for Occupational Safety and Health (NIOSH), pp. 17-34.

Mark C, Chase FE, Molinda GM [1994]. Design of longwall gate entry systems using roof classification. In: Special Publication 01-94, Proceedings of the U.S. Bureau of Mines Technology Transfer Seminar. New Technology For Longwall Ground Control.1994)U.S. Department of the Interior, Bureau of Mines, pp. 5-17.

Mark C, Phillipson S, Tyrna P, Gauna M [2012]. Characteristics of coal bursts in the North Fork Valley of the Gunnison River Valley, Colorado. In: Barczak T et al. eds. Proceedings: 31st International Conference on Ground Control in Mining. (Morgantown, WV: July 31-August 2, 2012) Morgantown, WV: West Virginia University, pp. 1-13.

MSHA [2009]. General guidelines for the use of numerical modeling to evaluate ground control aspects of proposed coal mining plans. By Skiles ME, and Stricklin KG. Program Information Bulletin No. P09-03, March 16, 2009, Arlington, VA: U.S. Department of Labor, Mine Safety and Health Administration (MSHA), 7 pp.

NIOSH [2020]. Ground stress in mining (part 2): Calibrating and verifying longwall stress models. By Larson MK, Tesarik DR, Johnson JC. U.S. Department of Health and Human 
Services, Centers for Disease Control and Prevention, National Institute for Occupational Safety and Health, DHHS (NIOSH). RI 9703.

Obert L, Duvall WI [1967]. Rock mechanics and the design of structures in rock, New York: John Wiley \& Sons, 650 pp.

Peng SS, Chiang HS [1984]. Longwall mining, New York: John Wiley \& Sons, 720 pp.

Phillipson SE [2005]. Laramide orogeny-related controls on coal mine ground instability in Cretaceous coal seams, southern Rocky Mountain foreland. Int. J. Coal Geol., Vol. 64, No. 1-2, pp. 20-43.

Robeck ED [2005]. The effects of fault-induced stress anisotropy on fracturing, folding and sill emplacement: Insights from the Bowie Coal Mines, Southern Piceance Basin, western Colorado. M.S. thesis. Provo, UT: Brigham Young University, Department of Geology, 106 pp.

Rockaway JD, Stephenson RW [1979]. Investigation of the effects of weak floor conditions on the stability of coal pillars. BUMINES-OFR-12-81 U.S. Department of the Interior, Bureau of Mines (USBM), 227 pp.

Sears MM, Heasley KA [2009]. An application of energy release rate. In: Peng SS et al. eds. Proceedings: 28th International Conference on Ground Control in Mining. (Morgantown, WV: July 28-30, 2009) Morgantown, WV: West Virginia University, pp. 10-16.

Sunderman C, Signer S, Johnson J [2003]. A miniature data acquisition system with LED warning lights, in Computer Applications in the Minerals Industries, Proceedings of the Fourth International Conference on Computer Applications in the Minerals Industries (CAMI 2003), ed. by Singhal RK et al. Calgary, AB, p. 7.

Thomas R, Wagner C [2006]. Main gate roof support design and management during longwall retreat in the Australian coal industry. In: Peng SS et al. eds. Proceedings: 25th International Conference on Ground Control in Mining. (Morgantown, WV: August 1-3, 2006) Morgantown, WV: West Virginia University, pp. 191-197.

Turnipseed MJ, Reeves Jr JA [1976]. Installation of an advancing longwall, Dutch Creek No. 1 Mine Mid-Continent Resources. In: American Mining Congress Coal Show, Session paper. Article, (Detroit, MI: May 10-13, 1976) Washington, D. C.: American Mining Congress.

USBM [1992a]. MULSIM/NL application and practitioner's manual. By Zipf RK, Jr. Information Circular 9322, Pittsburgh, PA: U.S. Department of the Interior, Bureau of Mines (USBM), 44 pp.

USBM [1992b]. MULSIM/NL theoretical and programmer's manual. By Zipf, RK, Jr. Information Circular 9321, Pittsburgh, PA: U.S. Department of the Interior, Bureau of Mines (USBM), $52 \mathrm{pp}$.

USBM [1994]. Coal Mine Roof Rating (CMRR): A practical rock mass classification for coal mines. By Molinda GM, and Mark C. Information Circular 9387, Pittsburgh, PA: U.S. Department of the Interior, Bureau of Mines (USBM), 83 pp.

Wilson AH [1981]. Stress and stability in coal ribsides and pillars. In: Peng SS ed., Proceedings: 1st Conference on Ground Control in Mining. (Morgantown, WV: July 27-29, 1981) Morgantown, WV: West Virginia University, pp. 1-8. 
Wilson AH, Ashwin DP [1972]. Research into the determination of pillar size. The Mining Engineer, Vol. 131, No. 141, Part 9, pp. 409-430.

Zingano A, Koppe J, Costa J [2004]. Violent coal pillar collapse - a case study. In: Peng SS et al. eds. Proceedings: 23rd International Conference on Ground Control in Mining. (Morgantown, WV: August 3-5, 2004) Morgantown, WV: West Virginia University, pp. 60-67. 



\section{Appendix A: Mine A-Borehole Pressure Cell Measurements}

\section{Description}

Measurements taken of BPC pressures with time appear in this appendix. Figures A1 to A3 show measurements of BPCs, installed as shown in Figure 12 of the main body of this report, at the 1 North inby site during retreat of Panel 1. In Figure A2, BPCs SP4 and SP5 were installed first and cables run to the datalogger before the other instruments, therefore their monitoring started at $59.25 \mathrm{hr}$, whereas the rest of the instruments were installed and monitoring began at $202.9 \mathrm{hr}$.

Measurements taken of the pressures of BPCs, installed as shown in Figure 15 at the 2 North inby site, are found in Figures A4 to A6 for Panel 1 retreat and Figures A7 to A9 for Panel 2 retreat. Breaks in monitoring were the result of damage to cables by passing machinery or rib falls. Many instruments failed before monitoring was ended.

Measurements taken of pressures of BPCs installed as shown in Figure 16 at the 1 North outby site during Panel 1 retreat are found in Figures A10 to A12. All cell pressures failed at or soon after the face passed. Dataloggers were removed just before the face passed the datalogger position and access became too risky.

Figures A13 to A15 show cell pressures with time of BPCs installed as shown in Figure 18 at the 2 North outby site during retreat of Panel 1. Cells SP2 and SP3 were damaged during installation and could not be pressurized to target setting pressure of 2,650 psi. A small break in monitoring occurred because datalogger battery voltage became too low. Battery replacement allowed monitoring to resume. Figures A16 to A18 show BPC pressure measurements of these same instruments during retreat of Panel 2. A mining-induced seismic event of magnitude 3.1 on the Richter scale occurred on February 17, 2011, at 17:47 local time (11,321.78 hr from zero time in the graphs) in the 2 North gate roads somewhere in the area between crosscuts 11 and 15. The face coordinate of Panel 2 in the tailgate was 2,768, or $261.5 \mathrm{~m}(858 \mathrm{ft})$ inby the 2 North outby BPC line. Surface arrays located the event near entry 2 between crosscuts 13 and 14, and surface and underground arrays located the event near entry 2 between crosscuts 11 and 12, thus reflecting the uncertainty in location calculations [Swanson 2014]. Vertical location could not be located accurately, but it was within the range of other mining-induced events [Swanson 2014]. Several BPCs were compromised as a result of this event. Monitoring with the datalogger continued on March 15, 2011, but mining progress was slow. The face was advanced to approximately crosscut 15. A decision was made to abandon part of Panel 2. A new startup room was developed at about crosscut 10, and the face was moved between March 25, 2011, and April 6,2011 , to the new startup room before panel mining resumed. As the new startup room was outby the datalogger, no further monitoring of BPCs at this site was possible. 
1 North inby BPCs in barrier pillar, panel 1

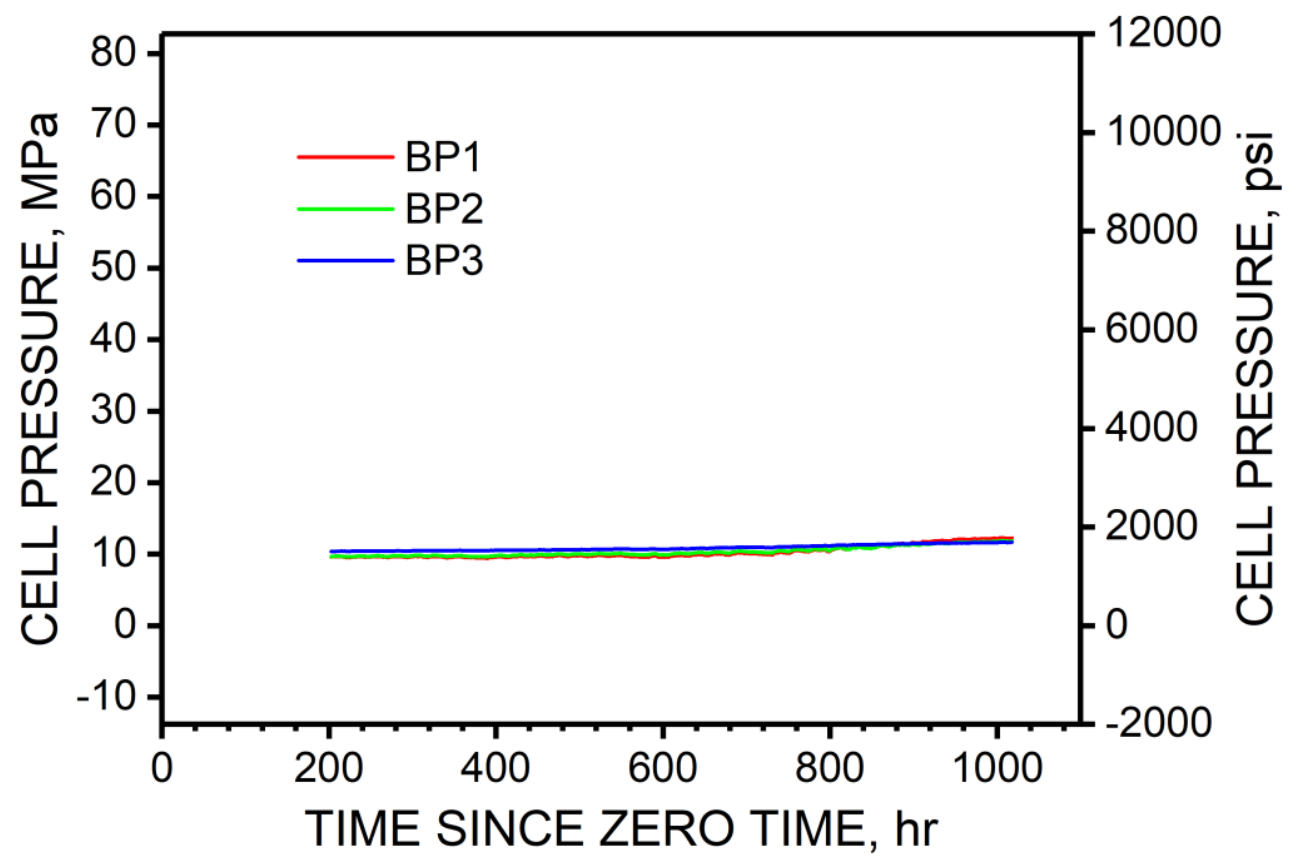

Figure A1. BPC pressures with time for cells in barrier pillar of 1 North inby site during Panel 1 retreat at Mine A.

1 North inby BPCs in south pillar, panel 1

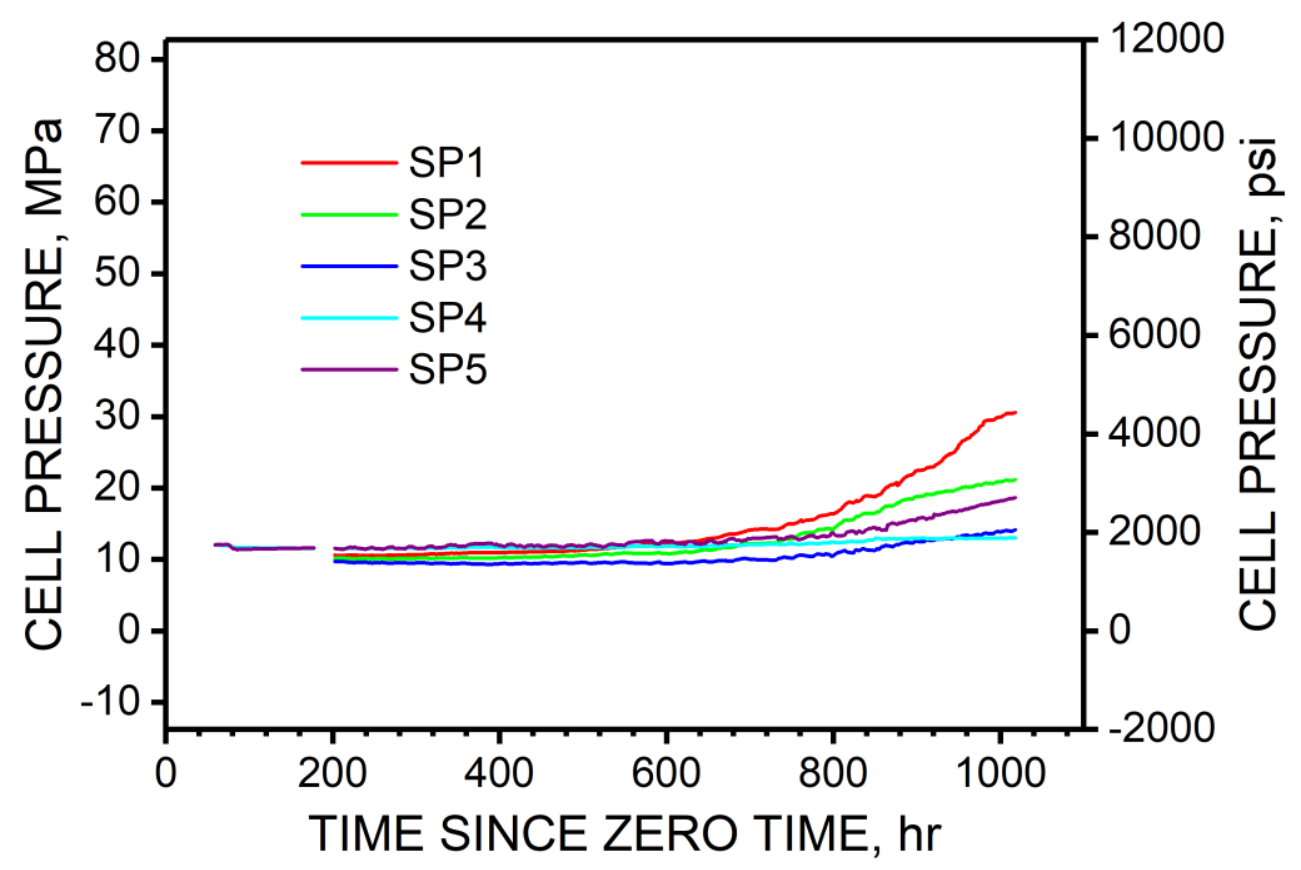

Figure A2. BPC pressures with time for cells in south pillar of 1 North inby site during Panel 1 retreat at Mine A. 
1 North inby BPCs in north pillar, panel 1

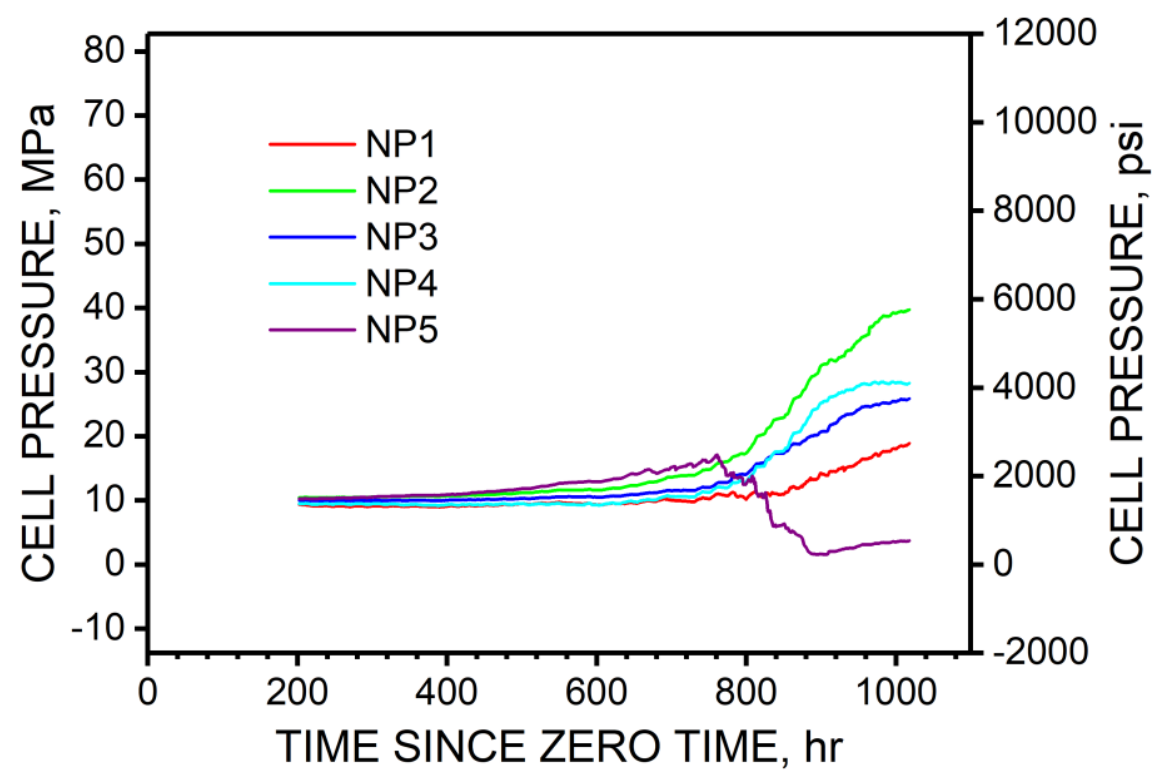

Figure A3. BPC pressures with time for cells in north pillar of 1 North inby site during Panel 1 retreat at Mine A.

2 North inby BPCs in south pillar, panel 1

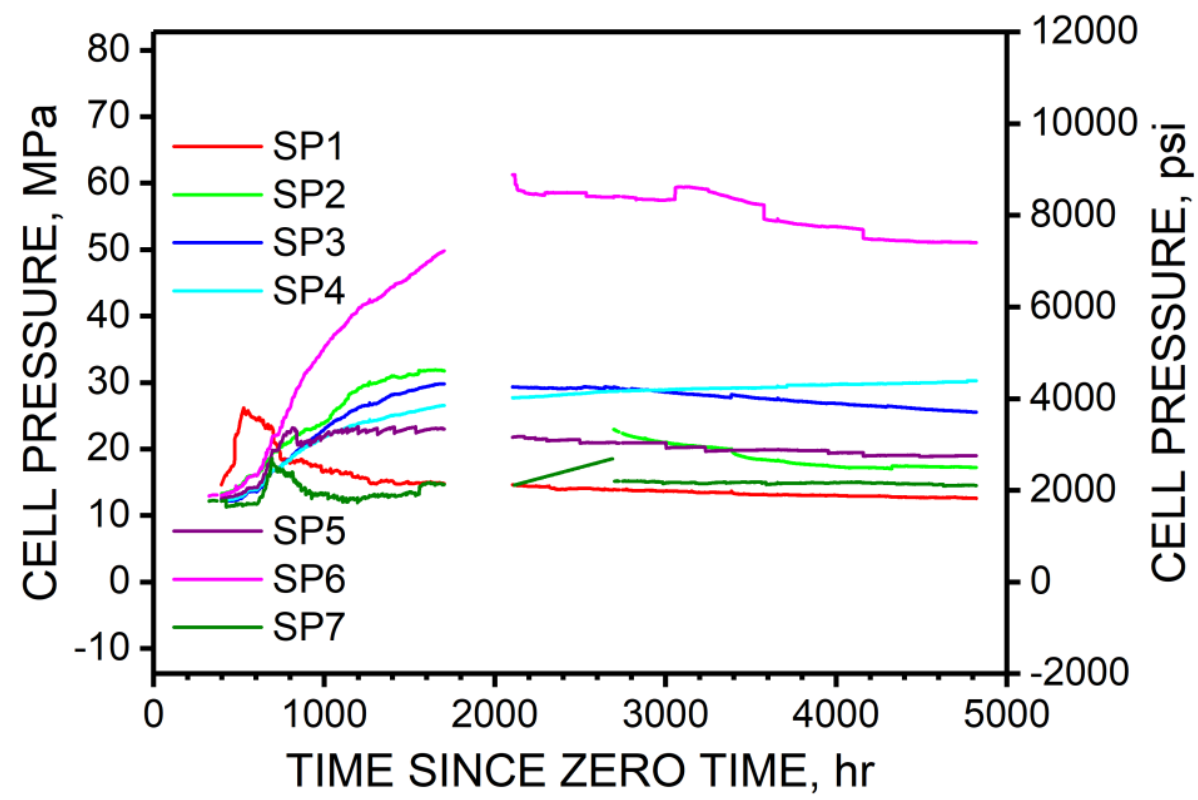

Figure A4. BPC pressures with time for cells in south pillar of 2 North inby site during Panel 1 retreat at Mine A. 
2 North inby BPCs in north pillar, panel 1

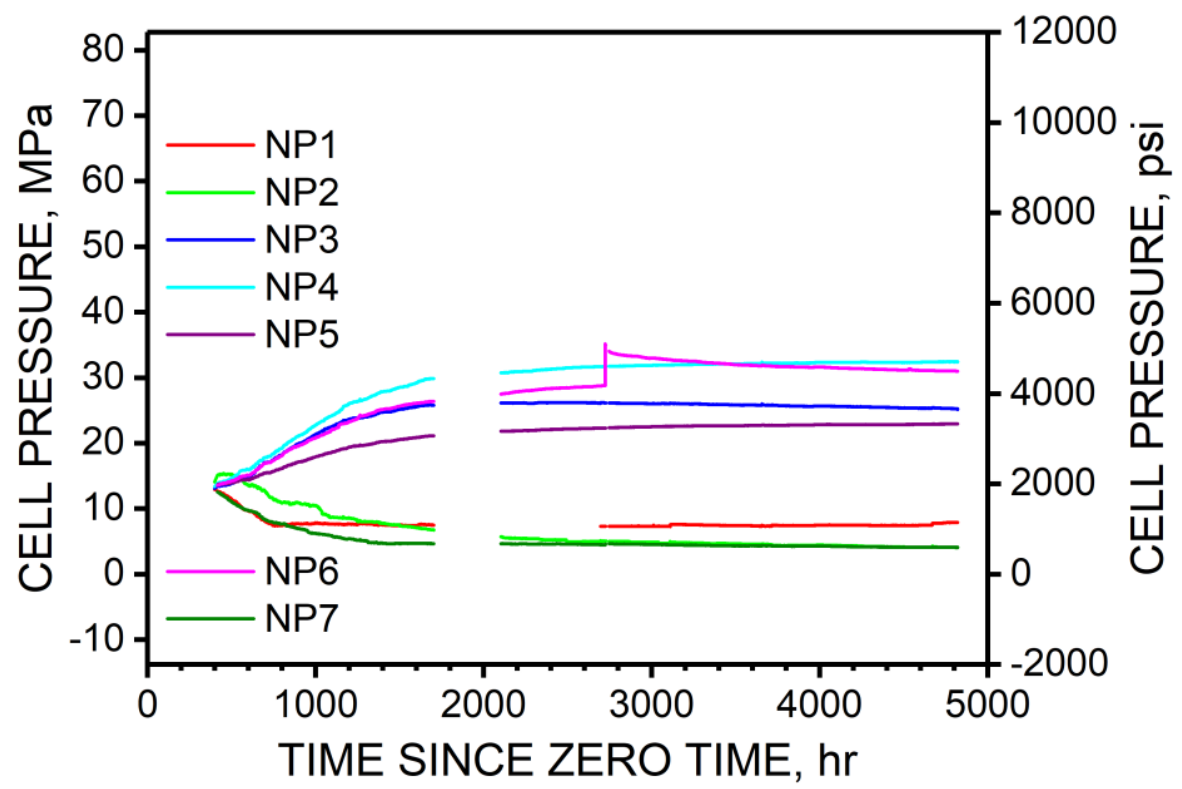

Figure A5. BPC pressures with time for cells in north pillar of 2 North inby site during Panel 1 retreat at Mine A.

2 North inby BPCs in barrier pillar, panel 1

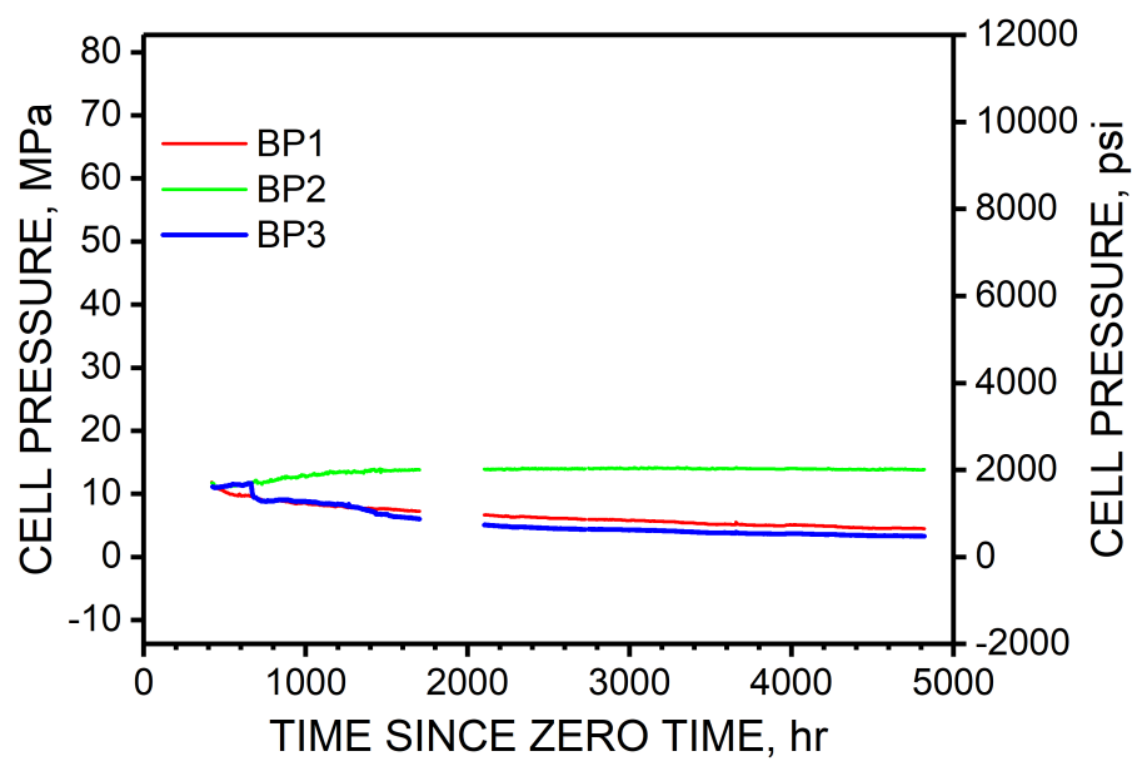

Figure A6. BPC pressures with time for cells in barrier pillar of 2 North inby site during Panel 1 retreat at Mine A. 
2 North inby BPCs in south pillar, panel 2

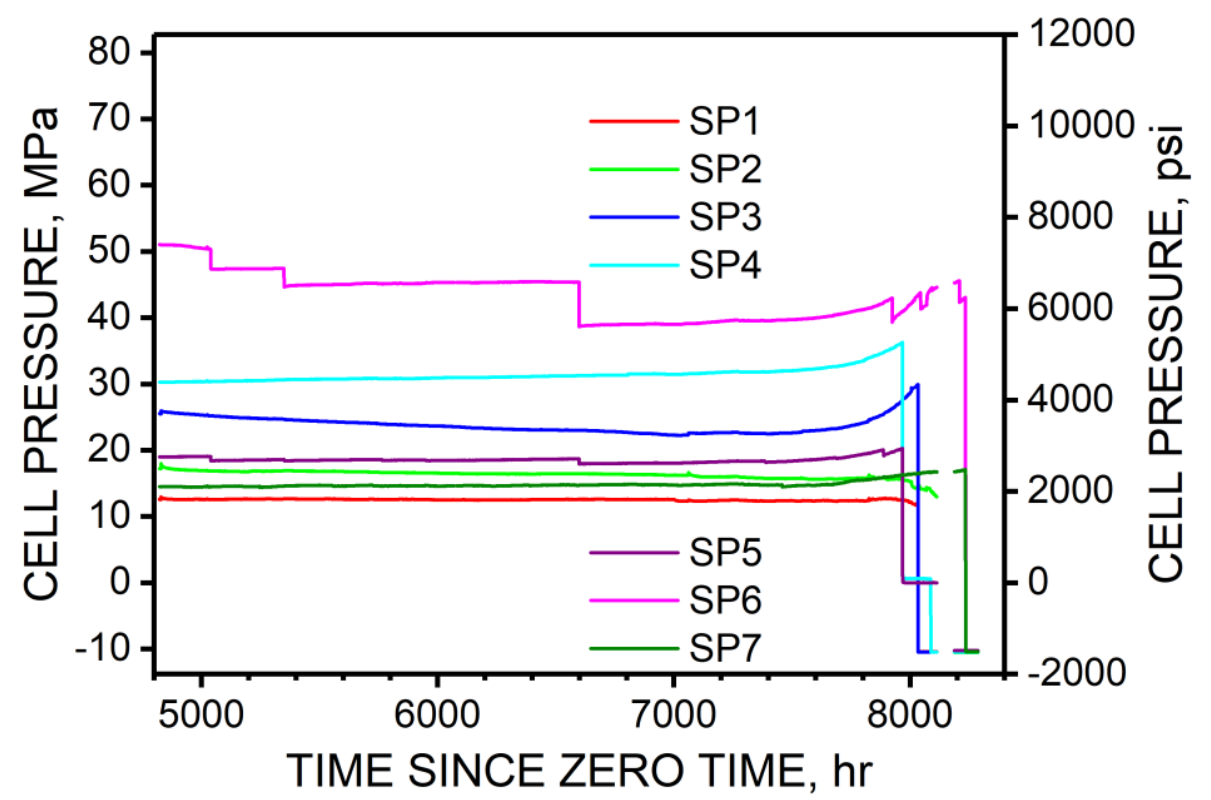

Figure A7. BPC pressures with time for cells in south pillar of 2 North inby site during Panel 2 retreat at Mine A.

2 North inby BPCs in north pillar, panel 2

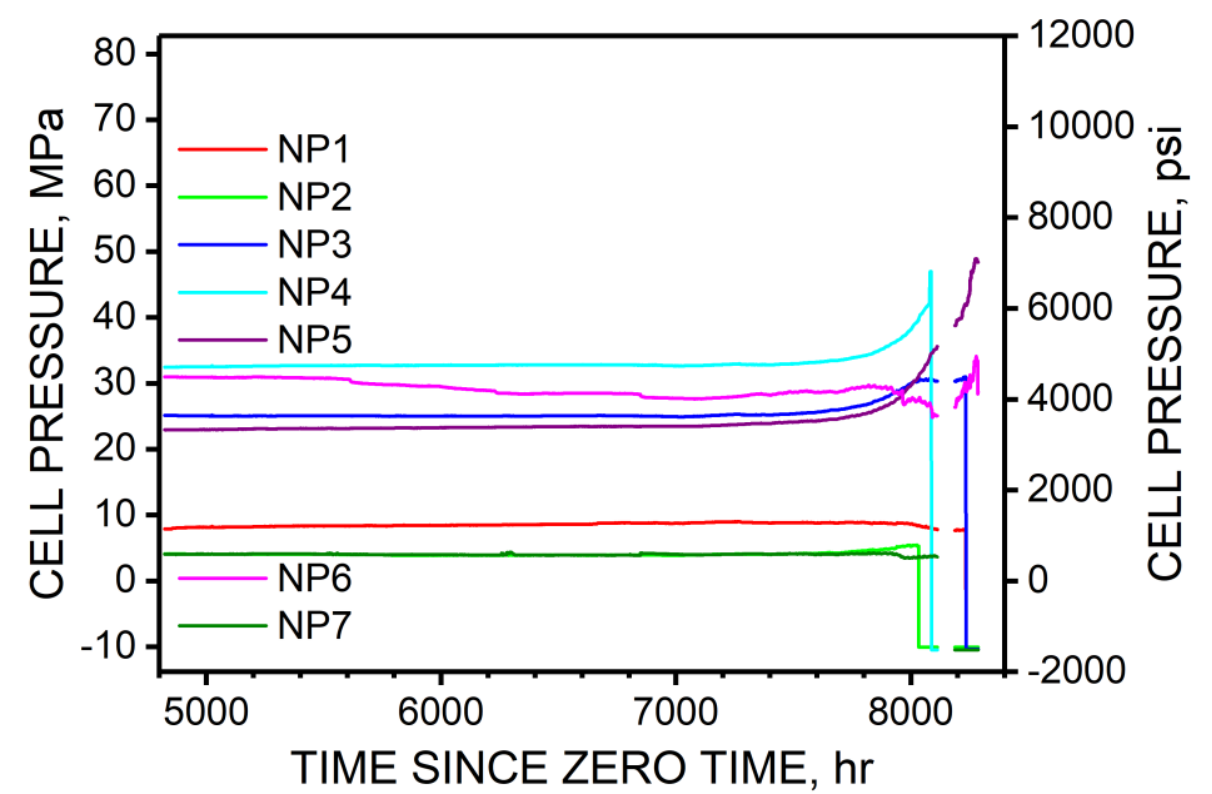

Figure A8. BPC pressures with time for cells in north pillar of 2 North inby site during Panel 2 retreat at Mine A. 
2 North inby BPCs in barrier pillar, panel 2

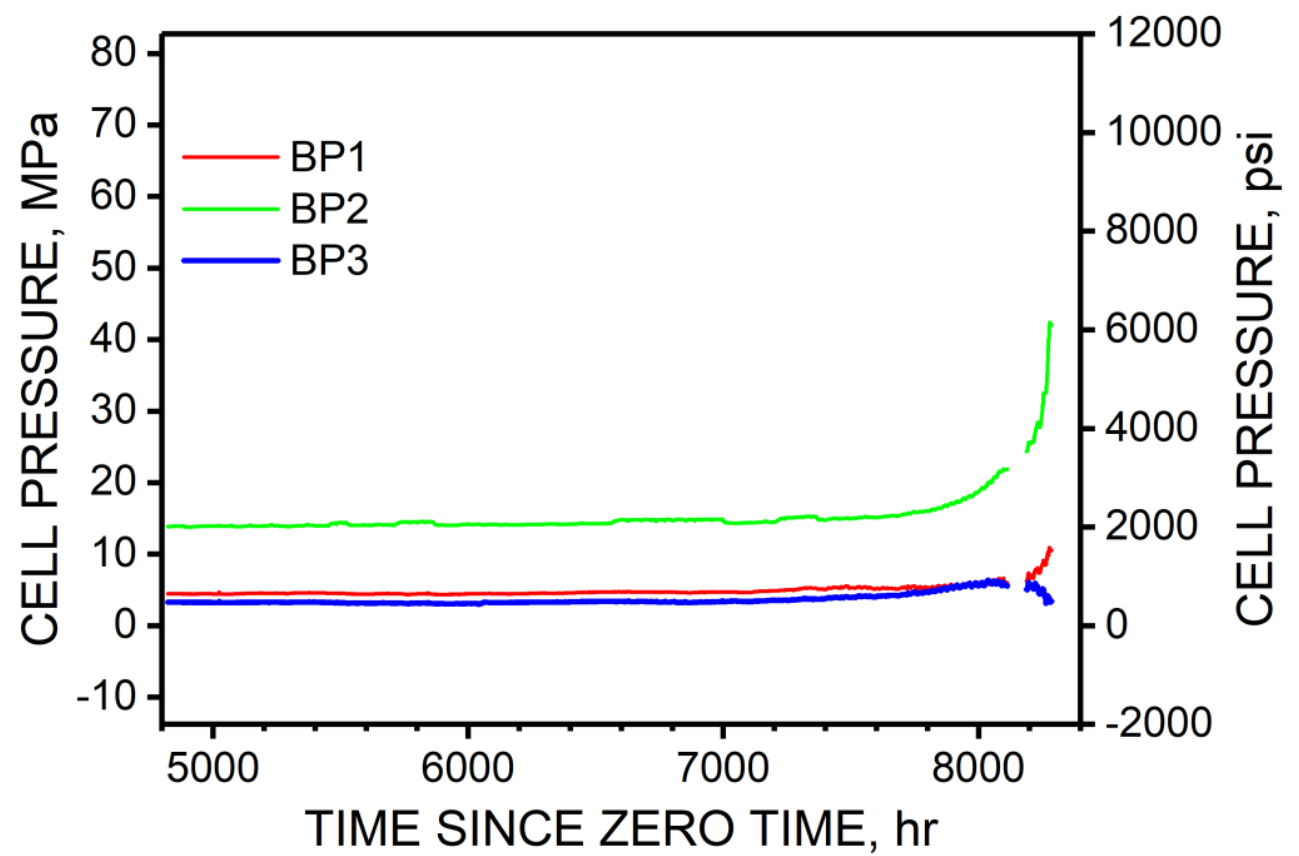

Figure A9. BPC pressures with time for cells in barrier pillar of 2 North inby site during Panel 2 retreat at Mine A.

1 North outby BPCs in barrier pillar, panel 1

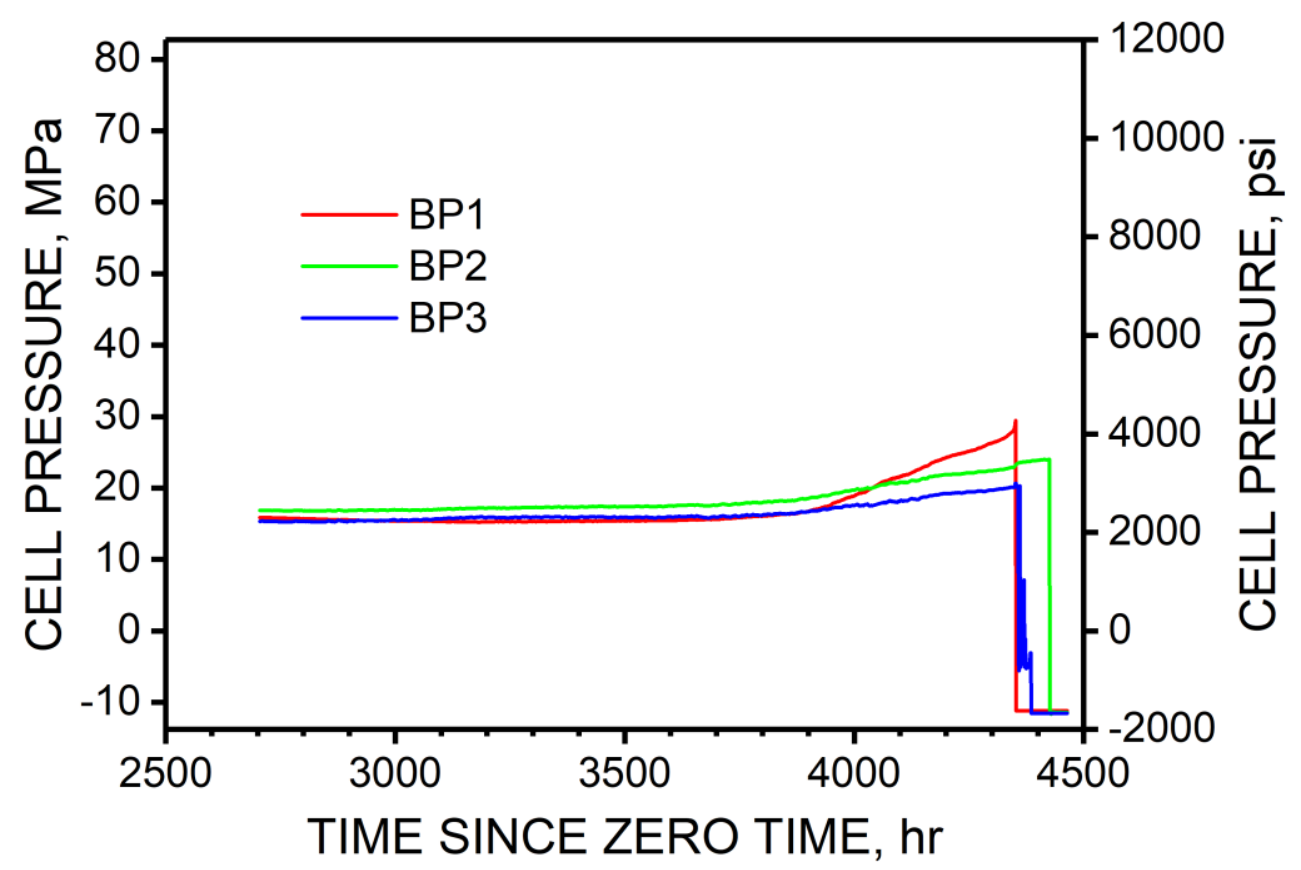

Figure A10. BPC pressures with time for cells in barrier pillar of 1 North outby site during Panel 1 retreat at Mine A. 
1 North outby BPCs in south pillar, panel 1

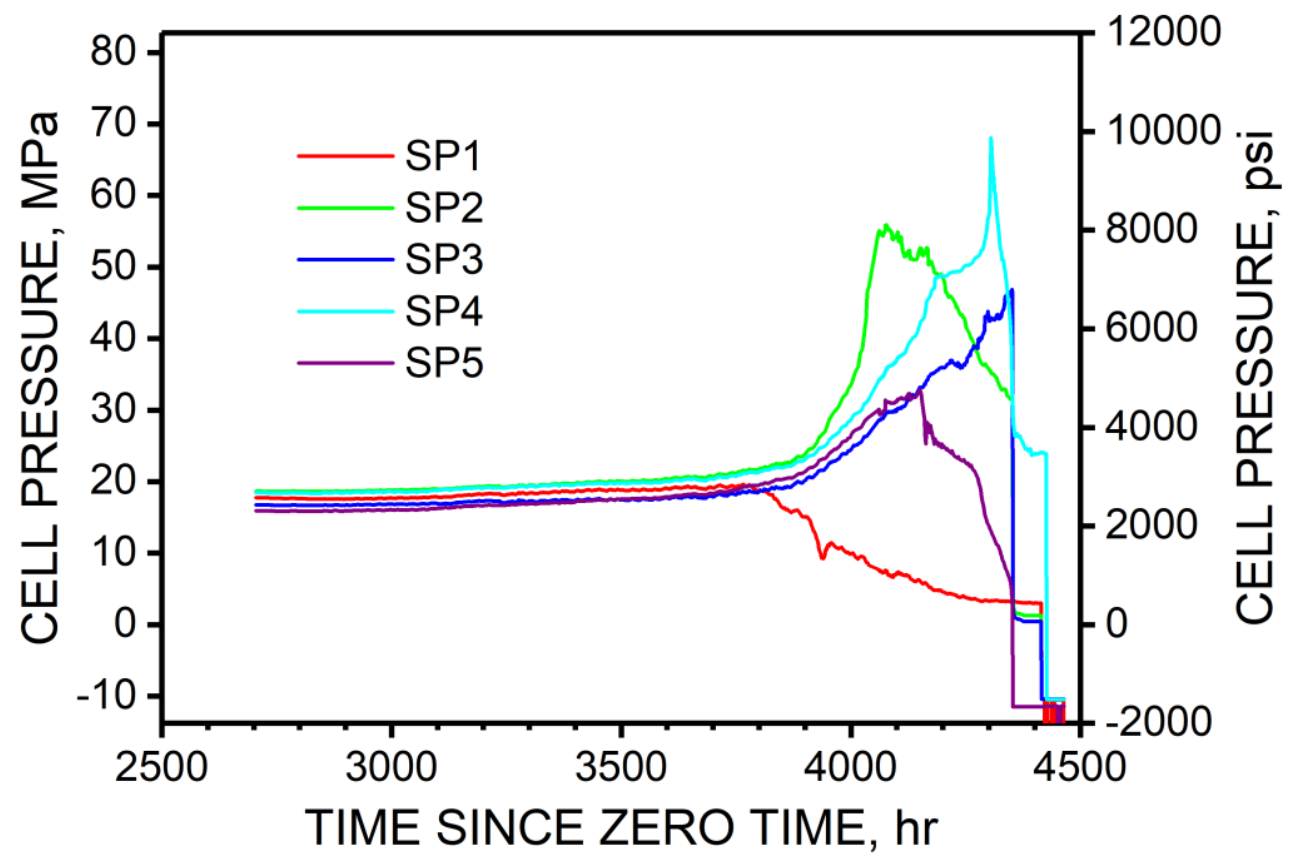

Figure A11. BPC pressures with time for cells in south pillar of 1 North outby site during Panel 1 retreat at Mine A.

1 North outby BPCs in north pillar, panel 1

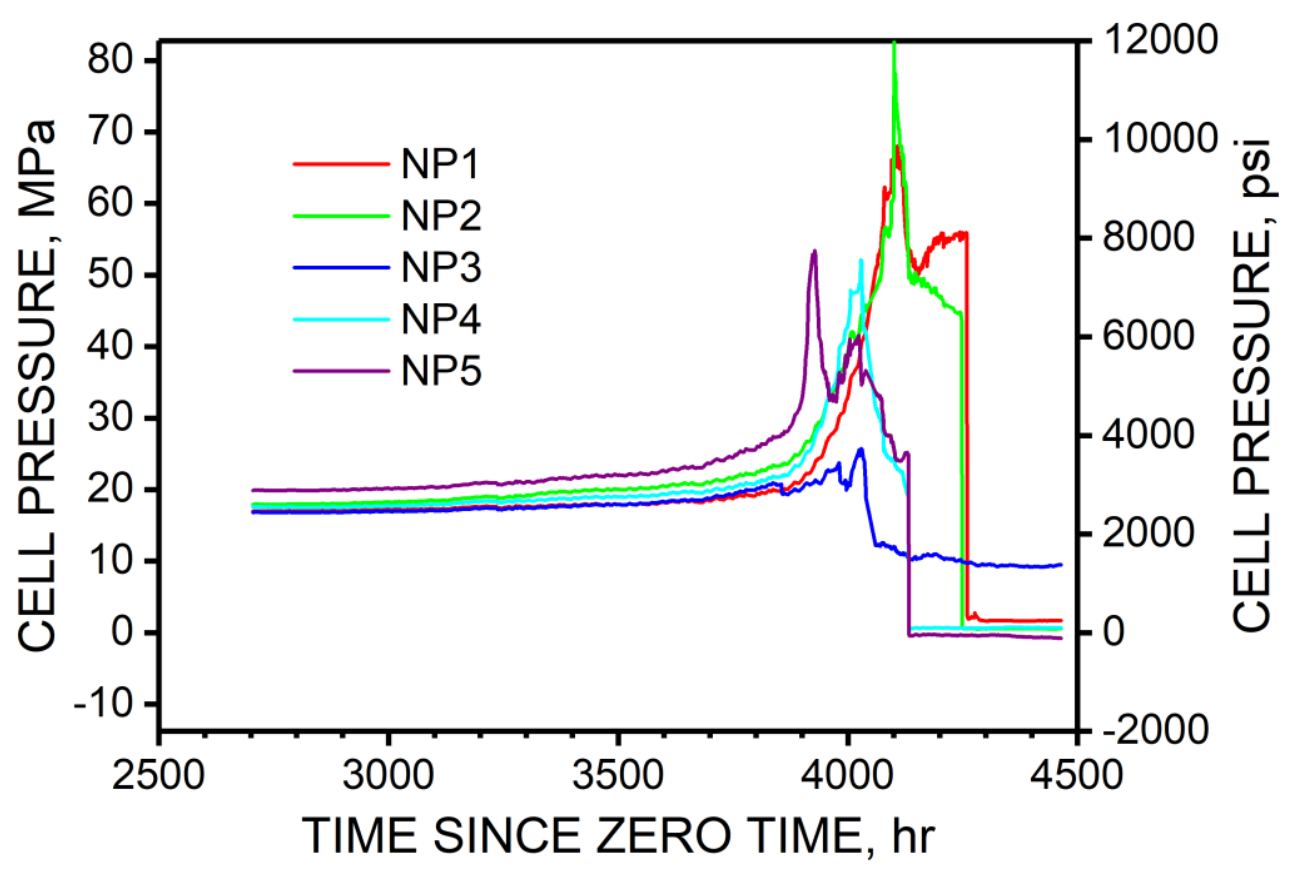

Figure A12. BPC pressures with time for cells in north pillar of 1 North outby site during Panel 1 retreat at Mine A. 
2 North outby BPCs in south pillar, panel 1

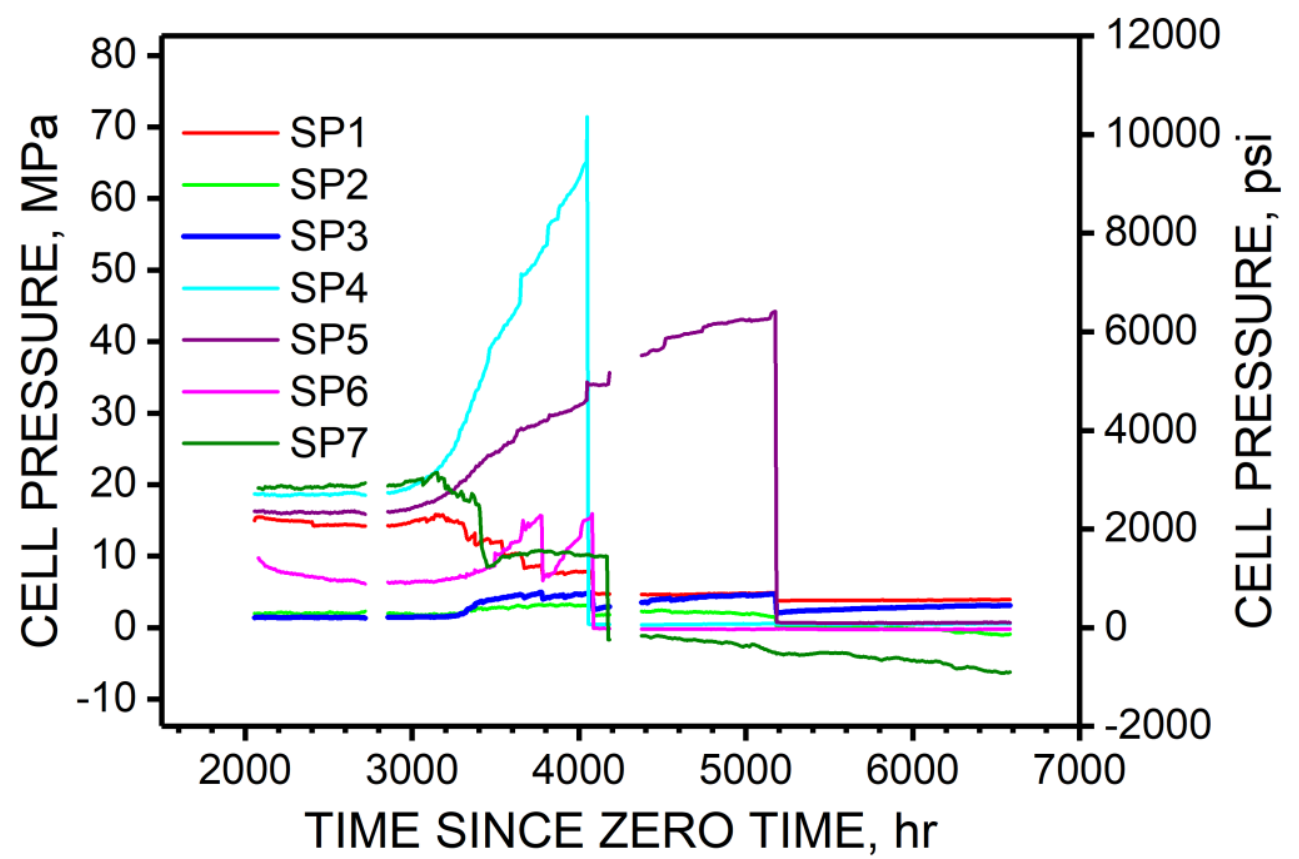

Figure A13. BPC pressures with time for cells in south pillar of 2 North outby site during Panel 1 retreat at Mine A.

2 North outby BPCs in north pillar, panel 1

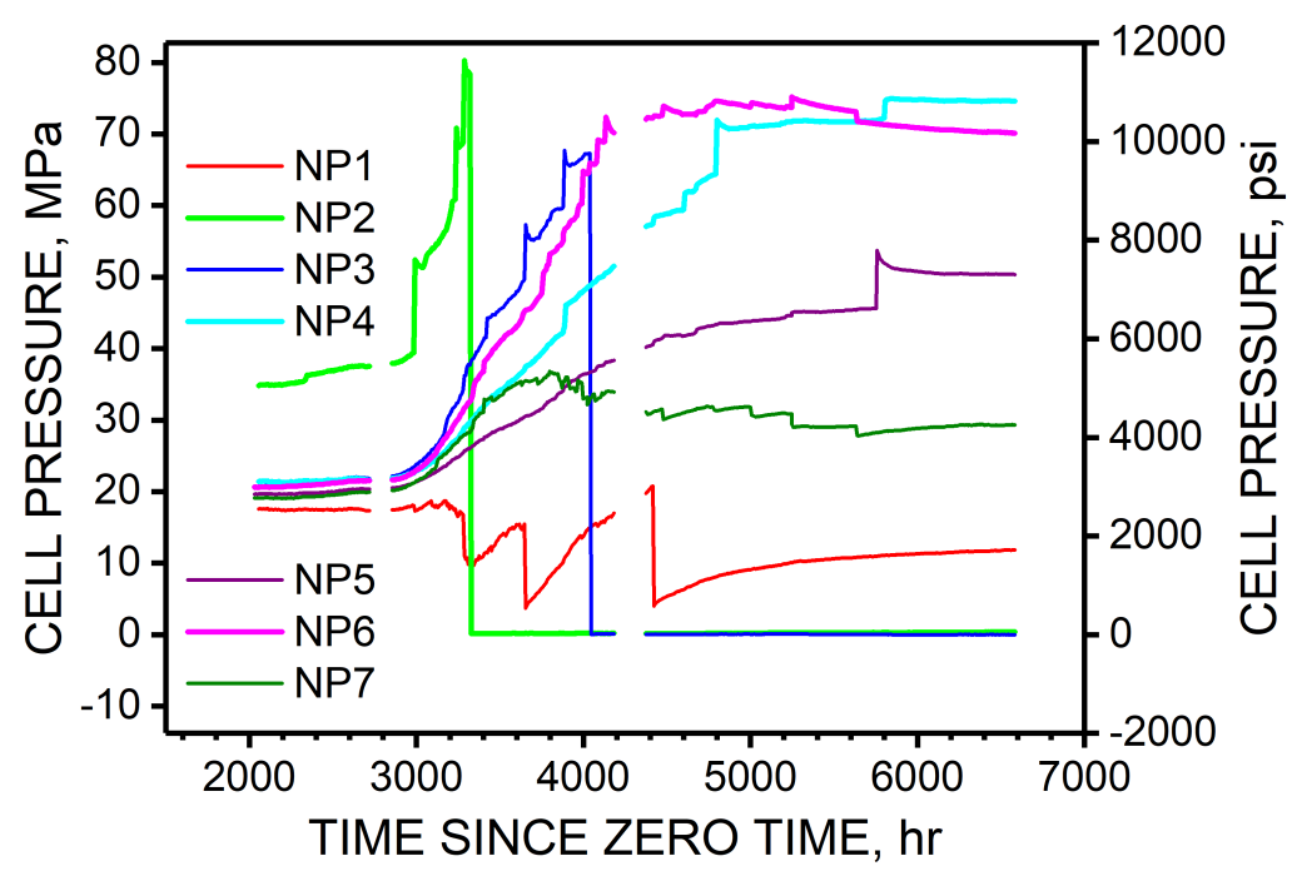

Figure A14. BPC pressures with time for cells in north pillar of 2 North outby site during Panel 1 retreat at Mine A. 
2 North outby BPCs in barrier pillar, panel 1

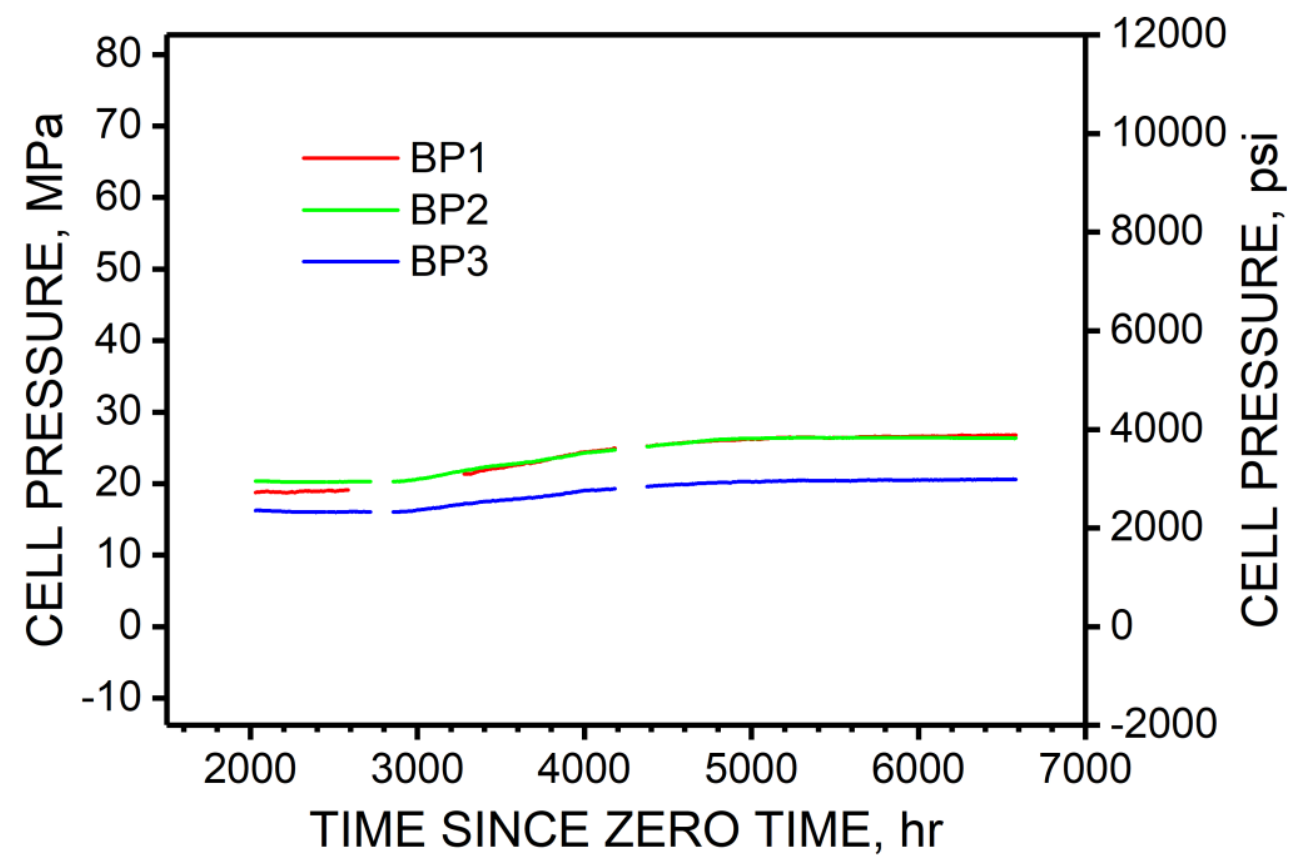

Figure A15. BPC pressures with time for cells in barrier pillar of 2 North outby site during Panel 1 retreat at Mine A.

2 North outby BPCs in south pillar, panel 2

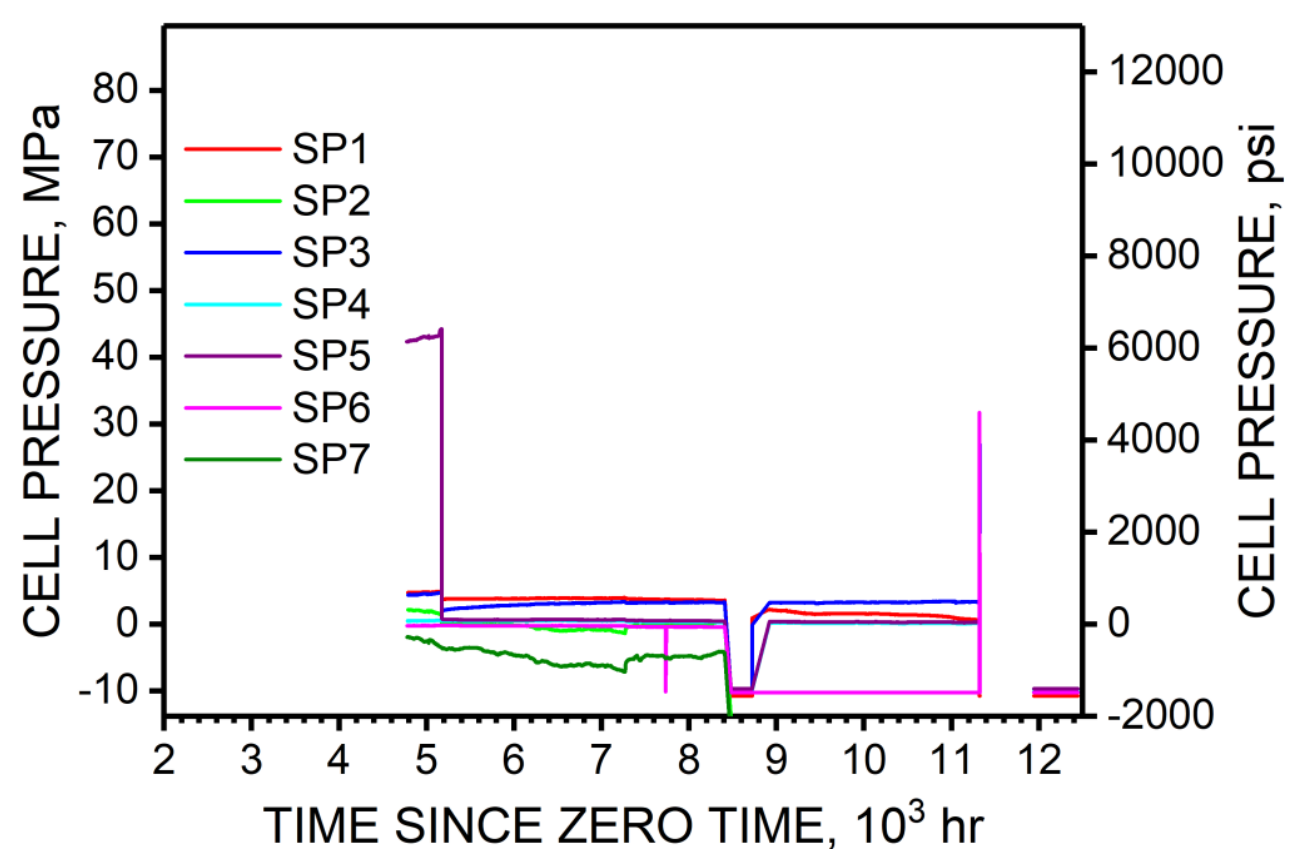

Figure A16. BPC pressures with time for cells in south pillar of 2 North outby site during Panel 2 retreat at Mine A. 
2 North outby BPCs in north pillar, panel 2

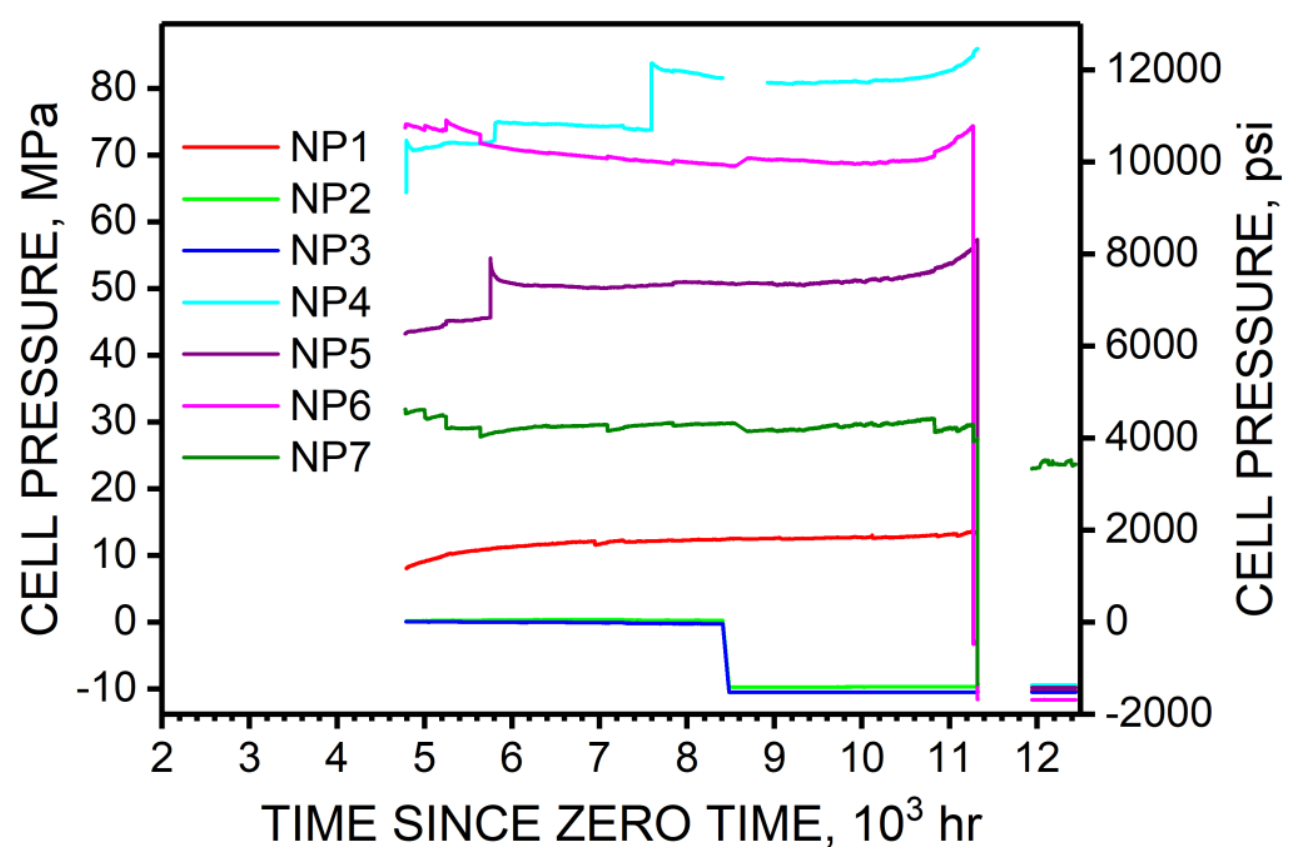

Figure A17. BPC pressures with time for cells in north pillar of 2 North outby site during Panel 2 retreat at Mine A.

2 North outby BPCs in barrier pillar, panel 2

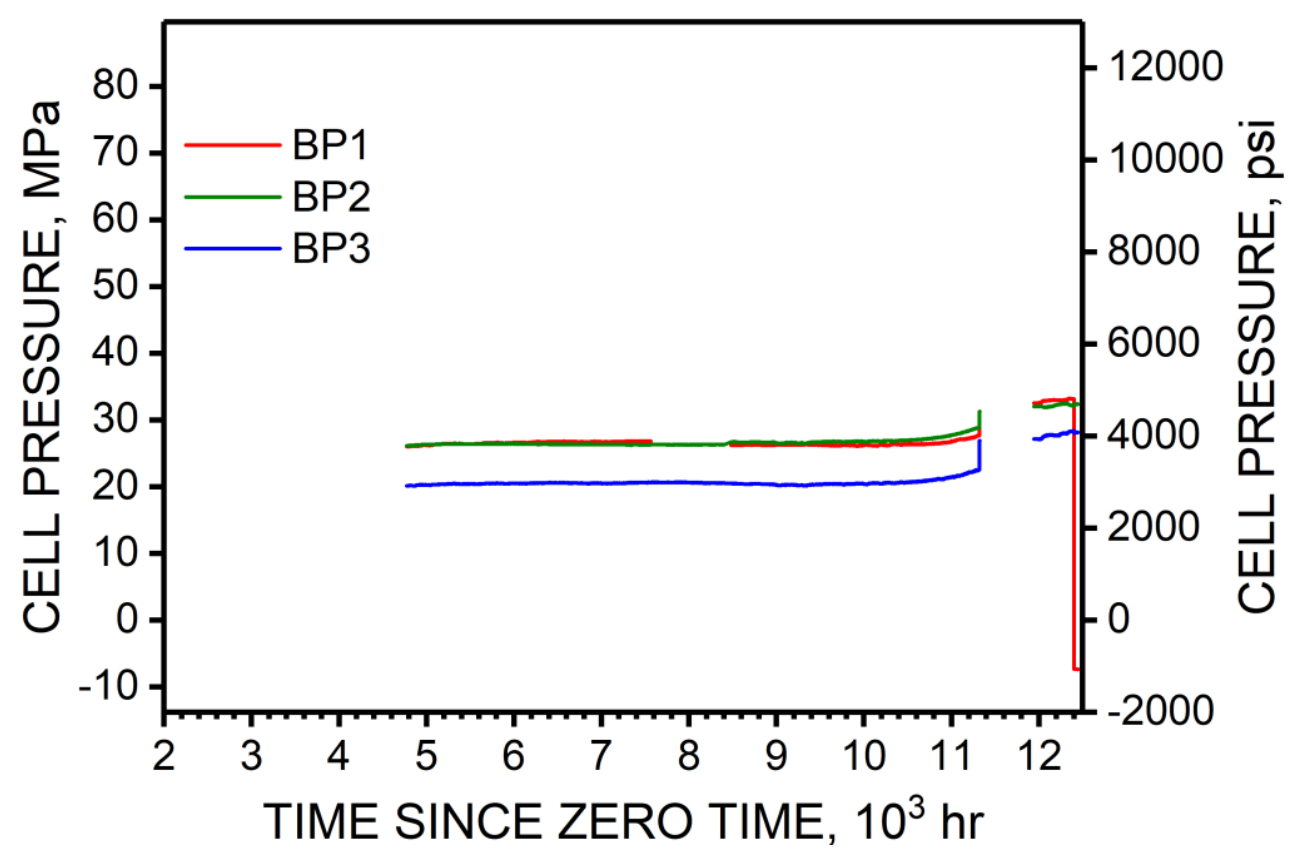

Figure A18. BPC pressures with time for cells in barrier pillar of 2 North outby site during Panel 2 retreat at Mine A. 


\section{References for Appendix A}

Swanson PL [2014]. E-mail, Personal communication to Larson MK, 4/3/2014. 



\section{Appendix B: Mine A-Support Can Measurements}

\section{Description}

The load on instrumented support Cans with time is shown in Figure B1. The instrumented bladders were installed on top of support Cans between thick pieces of plywood and below cribbing and wedges. They were installed, as shown in Figure 19 in the main part of this report, at the intersection of entry 3 and crosscut 10 in 2 North. Figure B2 shows loads on support Cans with time in entry 3 at approximately mid-pillar between crosscuts 9 and 10 in 2 North, as shown also in Figure 19. Both figures show the increase in load resulting from mining Panel 1, the gradual increase in load when no panel was being mined as entry 3 continued to close over time, the same trends during mining of Panel 2 while the face was far away, and the large increases in load associated with a bump that occurred inby the instrumented support Cans.

Figure B3 shows relative closure between two points at each Can. The upper point was mounted in the cribbing and wood wedges above the Can and instrumented bladder. The other point comprised a screw attached to the Can very close to the floor. A string potentiometer, monitored by the same dataloggers that monitored the Cans, measured relative position between these points on each Can. In addition, two roof-to-floor closures at stations labeled Roof-Floor 9 and Roof-Floor 10 in the intersection of entry 3 with crosscut 10, as shown in Figure 19, were monitored with the dataloggers and shown in Figure B3. Figure B4 shows relative closure between the same kinds of points at each Can in entry 3 at approximately mid-pillar between crosscuts 9 and 10. In addition, it shows relative closure of roof-to-floor distance at four locations, labeled as Roof-Floor 7 through Roof-Floor 10 as indicated also in Figure 19. These figures show closures having the same trends as do the loads, but opposite in sense. A negative relative closure indicated a shortening of the Can or of the roof-to-floor distance. These correspond well to increase in load on the Cans, including the bump, where there was a sudden closure on the Cans and entries. The roof-to-floor closures were greater than Can closures, as expected. The data trends are consistent and believable.

As a check, four manual closure stations were established, two in each of these areas, whose locations are also shown in Figure 19. These stations were monitored manually with a tape measure to the nearest $0.32 \mathrm{~cm}(0.125 \mathrm{in})$. Results, shown in Figure B5, are similar in amount to the roof-to-floor closures shown in Figures B3 and B4, thus serving to verify the closures measured with string potentiometers.

Although the Can closures are smaller than the entry closure measured between the Cans, as expected, the amounts of entry closure vary significantly. This variation might result from relative location with respect to nearby Cans, but it might also reflect a high degree of variation of geology and structural features in the roof and floor within a short horizontal distance. 
2 North support Cans, entry 3, crosscut 10

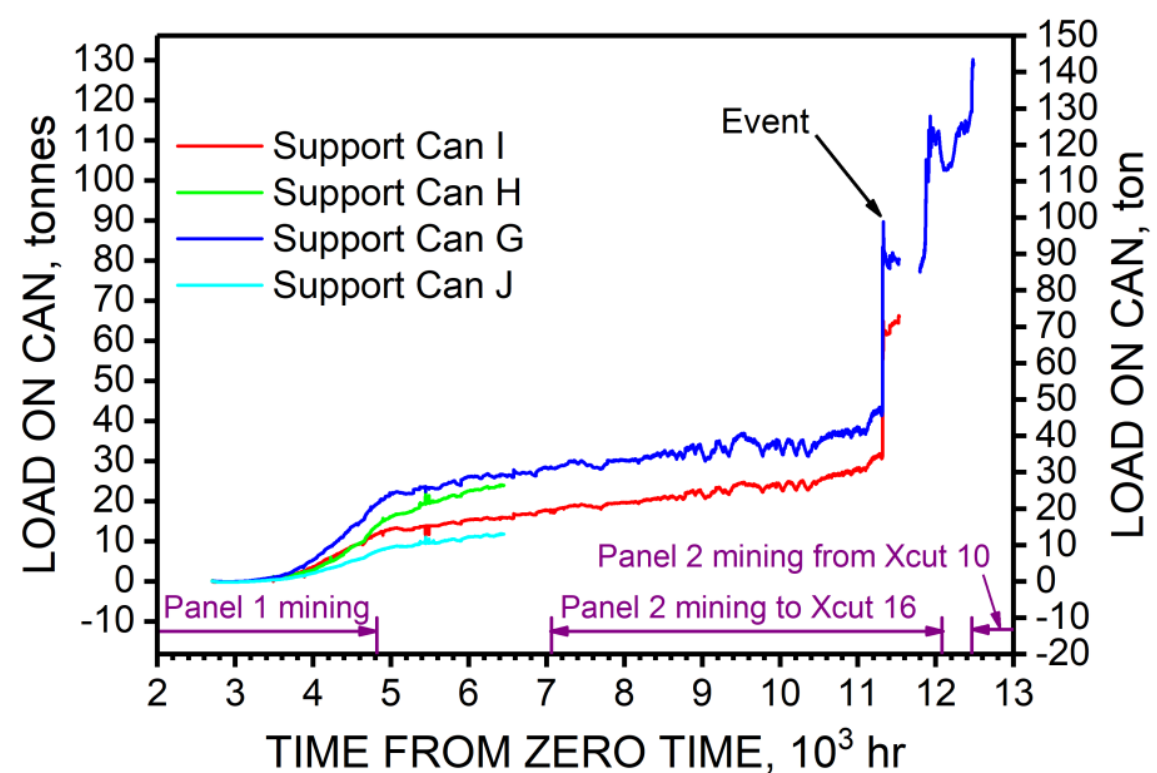

Figure B1. Load on support Cans with time for support Cans located in 2 North gate roads at intersection of entry 3 and crosscut 10 at Mine A.

2 North support Cans, entry 3 , between crosscuts 9 and 10

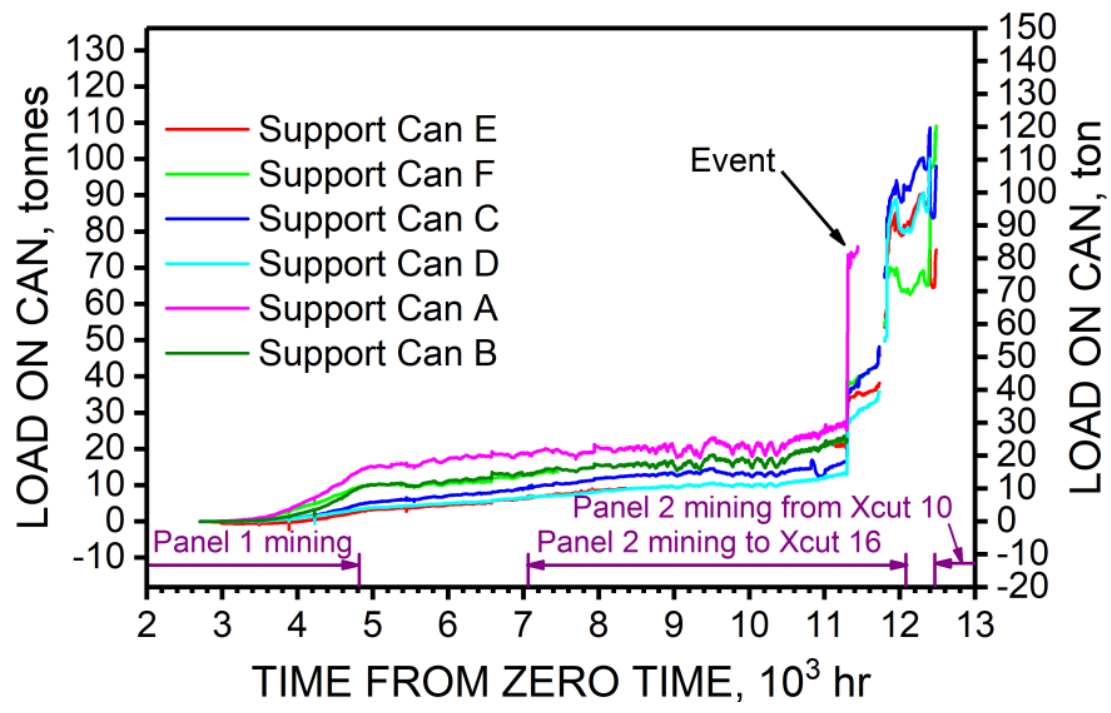

Figure B2. Load on support Cans with time for support Cans located in 2 North gate roads at mid-pillar in entry 3 between crosscuts 9 and 10 at Mine $A$. 
2 North support Can string pot. extensometers

Entry 3, crosscut 10

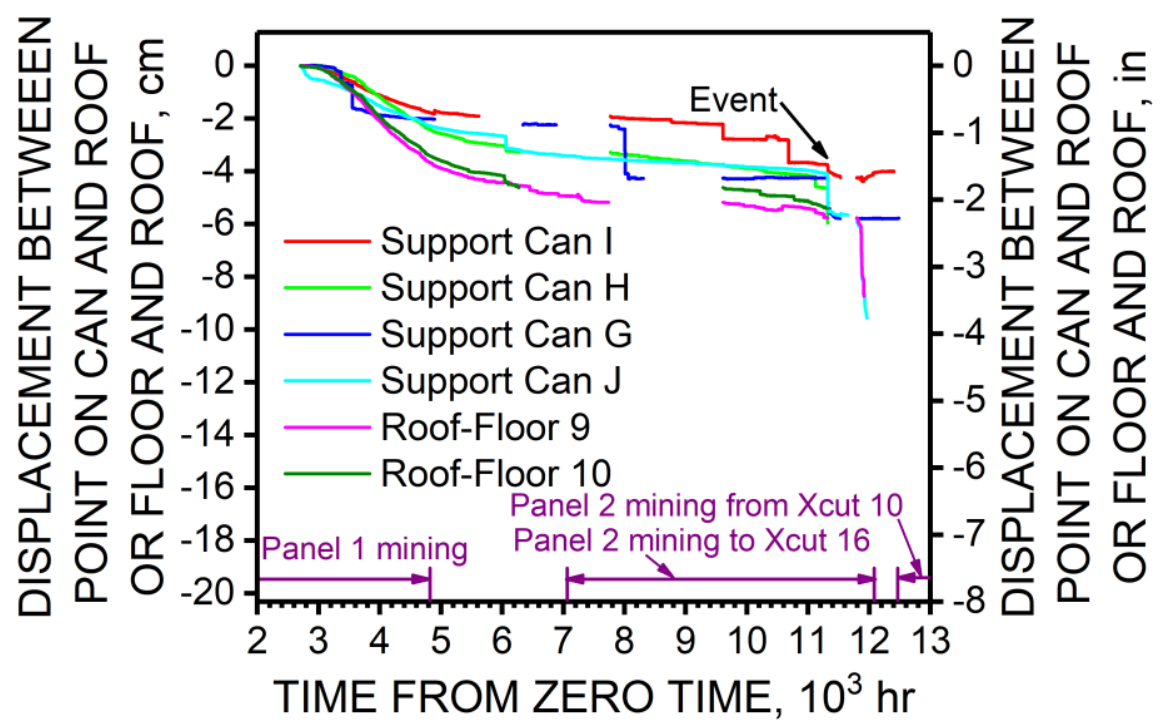

Figure B3. Closure of support Cans with time for support Cans located

in 2 North gate roads in entry 3 at crosscut 10 at Mine A. The closure for a Can is between an anchor in the cap wood and an anchor mounted at the base of the Can.

2 North support Can string pot. extensometers Entry 3, between crosscuts 9 and 10

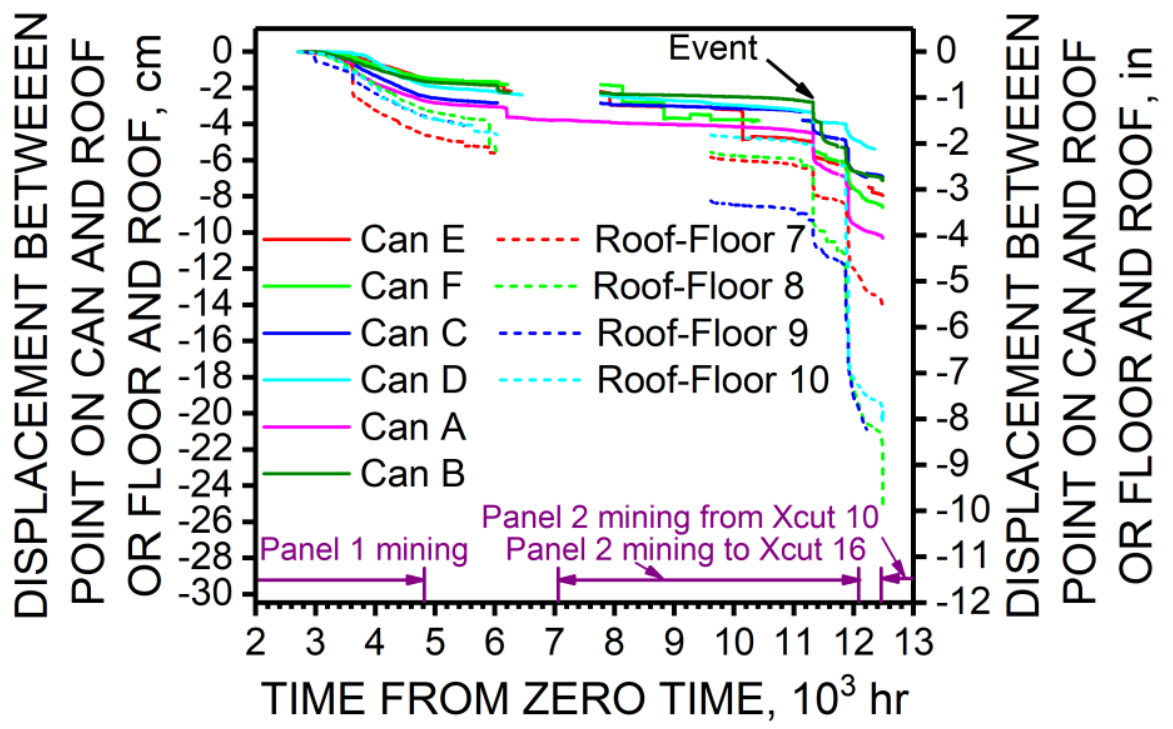

Figure B4. Closure of support Cans with time for support Cans located in 2 North gate roads in entry 3 at mid-pillar between crosscuts 9 and 10 at Mine A. The closure for a Can is between an anchor in the cap wood and an anchor mounted at the base of the Can. Other roof-to-floor closures were measured between sets of Cans. 


\section{Manual roof-to-floor closure measurements near support Cans}

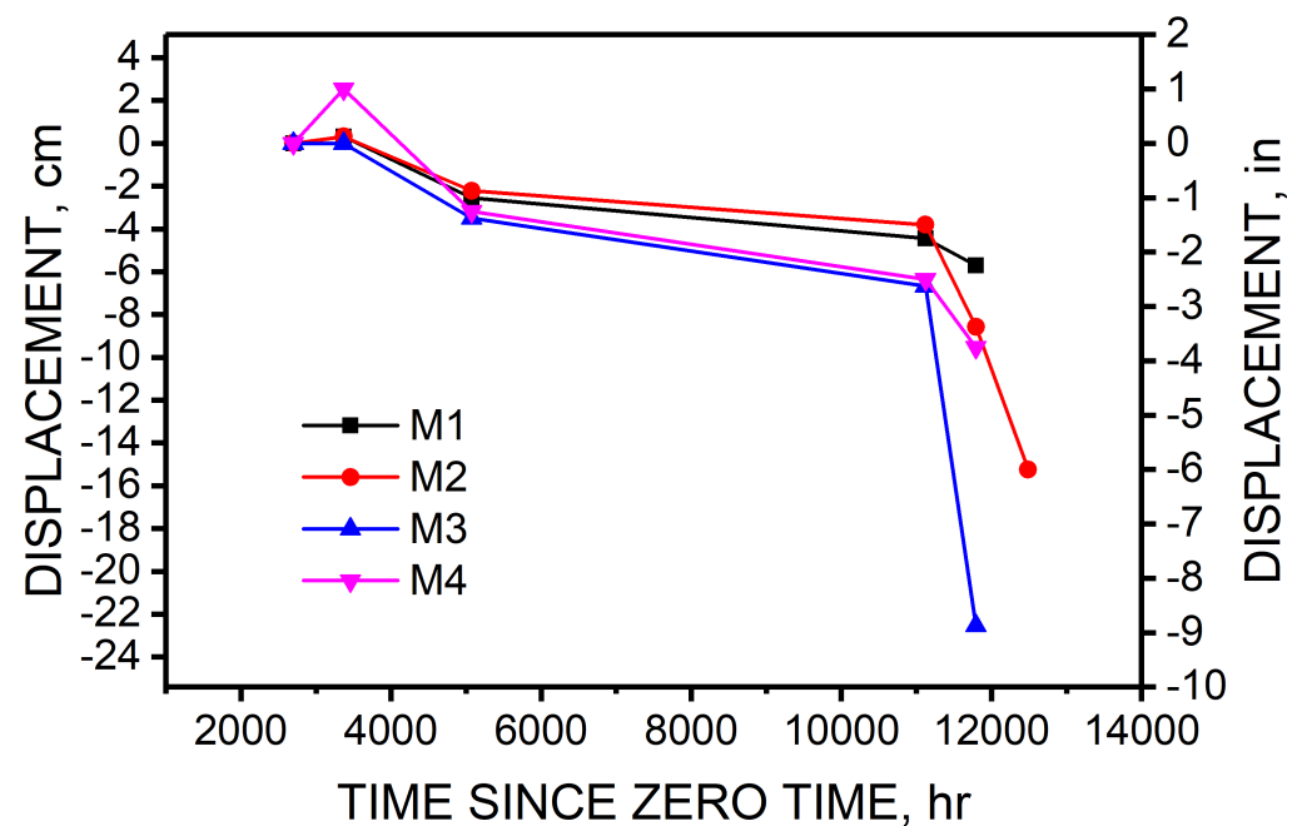

Figure B5. Manual roof-to-floor closure measurements taken near support Cans at Mine A. Locations shown in Figure 19. Measurements taken with tape measure to the nearest $0.32 \mathrm{~cm}(0.125 \mathrm{in})$. 


\section{Appendix C: Mine A-Entry Closure and Roof Sag Measurements}

\section{Description}

Measurements of closure and roof sag were taken manually or with dataloggers at the instrumentation sites. Closure stations had to be manual in nature because of the necessity for travel with equipment and workers, except those previously reported in Appendix B. Because of exposure of floor points to traffic and equipment, floor points inadvertently were destroyed before closure monitoring ceased. No roof extensometers were installed at the 1 North inby site, given the short time available to prepare instruments. Manual MPBXs were installed at the 2 North inby site. NIOSH-manufactured roof extensometers were installed at both outby sites. These extensometers included strong springs for up-hole anchors. Collar structures were attached to the roof with small bolts and anchors while string potentiometers were mounted on brackets on this structure outside the borehole. Piano wire ran from each anchor to a separate string potentiometer, all of which were monitored along with the BPCs with Campbell Scientific 21X dataloggers. Two sonic probes were installed at each of the outby sites to supplement the roof extensometers.

Manual closures are shown in Figures C1-C4 for the 1 North inby, 2 North inby, 1 North outby, and 2 North outby instrumentation sites, respectively. Locations of the stations in each site are shown in Figure 12 and Figures 15, 16, and 18 in the main part of this report. The 1 North inby site showed very little closure, but roof and floor deterioration was minimal. At the 2 North inby site, several closure stations were lost, but some stations showed closure over $1.5 \mathrm{~m}$ (5 ft), especially as Panel 2 approached the site. At the 1 North outby site, because only one panel passed by this area, the amount of closure was significantly less than at the 2 North inby site, but two 1 North stations in particular - those at mid-pillar in entries 2 and 3 - had significantly more closure than did the stations in crosscut 8 , even with comparative proximity to the panel. Although several factors could contribute to this difference in closure among stations, one strong implication is differences in geology of the roof and floor at stations $\mathrm{B}$ and $\mathrm{C}$ compared to that of the roof and floor along crosscut 8 . Early loss of stations at the 2 North outby site do not allow support of any implications concerning consistency or variability of geology.

Figure C5 shows results of measurements of roof sag over time as measured with the MPBX at the 2 North inby station during mining of both panels 1 and 2 and time between that mining. The instruments are reasonably consistent. However, if installations were perfect and geology was uniform, one would expect extensometers 1 and 2 to show more sag during Panel 1 mining; extensometer 4, in entry 3, to show the most response during Panel 2 mining; and extensometer 3 to have more response than extensometers 1 and 2 during Panel 2 mining. In fact, extensometer 3 had the largest response from start to finish, followed by extensometer 1 in entry 2 at mid-pillar. Extensometer 4 had little to no response during the entire monitoring period. No information is available at this writing that shows proximity to support Cans, but Cans were not installed and in place during the entire monitoring period. Other possible reasons for the unexpected level of responses might be quality of installation and variable local geology. Likely, the unexpected response levels were the result of several factors.

Figures C6-C10 show relative displacement between the collar and three anchors up the borehole for stations 1 through 5 at the 1 North outby instrumentation site. These roof sag stations are labeled in order of proximity to Panel 1. A negative sign of displacement signifies that the collar sags with respect to the anchor, as for the MPBXs. The measurements, while 
showing movement beyond the range of the potentiometers in several cases, were consistent and showed expected relative magnitudes among the stations - that is, magnitude of sag was consistent with proximity to the panel in that crosscut.

Figures C11-C15 show relative displacement between collar and up-hole anchors for stations 1 through 5 at the 2 North outby instrumentation site during mining of Panel 1 . At this site, the roof sags are not consistent with expected results, assuming good installation and uniform geology. Again, although information on proximity to support Cans is not available, the results suggest variable roof geology, because relative success was achieved with the same instruments at the 1 North outby instrumentation site.

Figures C16-C20 show relative displacement between collar and up-hole anchors for stations 1 through 5 at the 2 North outby instrumentation site during mining of Panel 2. Extensometer sets 1 and 3 are inconsistent in sag by anchor, but sets 2, 4, and 5 are consistent. The responses show a large increase in sag rate as the Panel 2 face approached. The large sag rates varied, thus also suggesting variability in geology among the sites.

Figure C21 shows nominal depths used for sonic probe anchor installation. Two such assemblies were installed, each at the outby instrumentation sites (see Figures 16 and 18). Figures C22 and C23 show relative displacement measured with respect to the deepest anchor in the borehole for the two assemblies installed at the 1 North outby site. In the graphs, roof sag is negative in sign. The instruments show that minor roof sag happened during mining of Panel 1 at

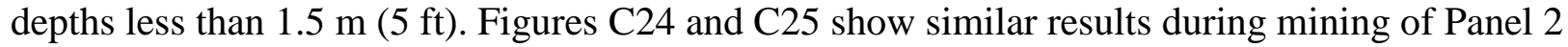
for the two sonic probe assemblies installed at the 2 North outby instrumentation site. Of these only the sonic probe installed at approximately mid-pillar in entry 3 showed significant relative displacement, particularly as the Panel 2 face approached. Although the probe at the intersection

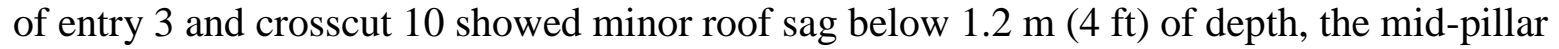
probe showed significant sag in that range and also above $4 \mathrm{~m}(13 \mathrm{ft})$ of depth. This result also supports the implication from closure and roof extensometer measurements in 2 North that the roof strata are not uniform and consistent. 


\section{North inby instrumentation site}

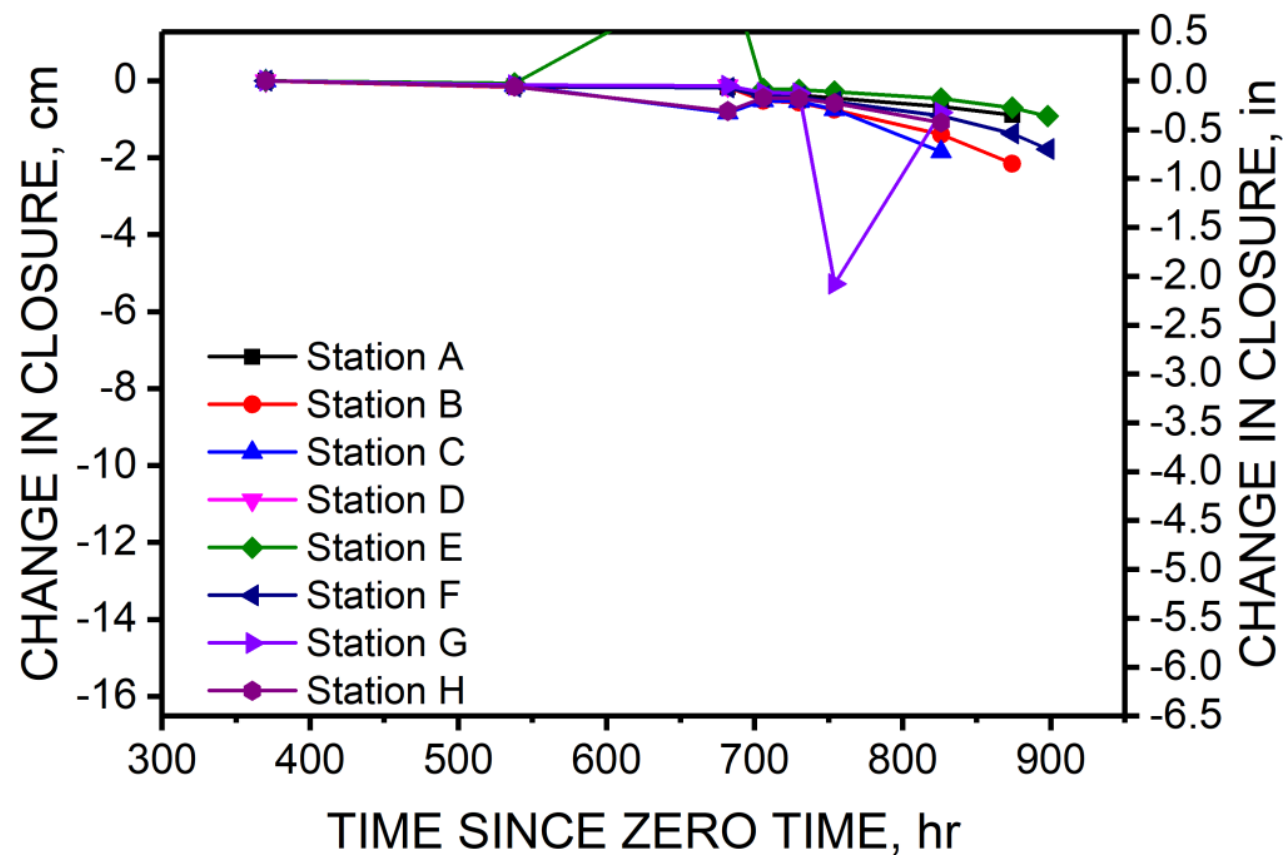

Figure $\mathrm{C} 1$. Entry closure with time of manually read stations at 1 North inby instrumentation site at Mine $A$.

2 North inby instrumentation site

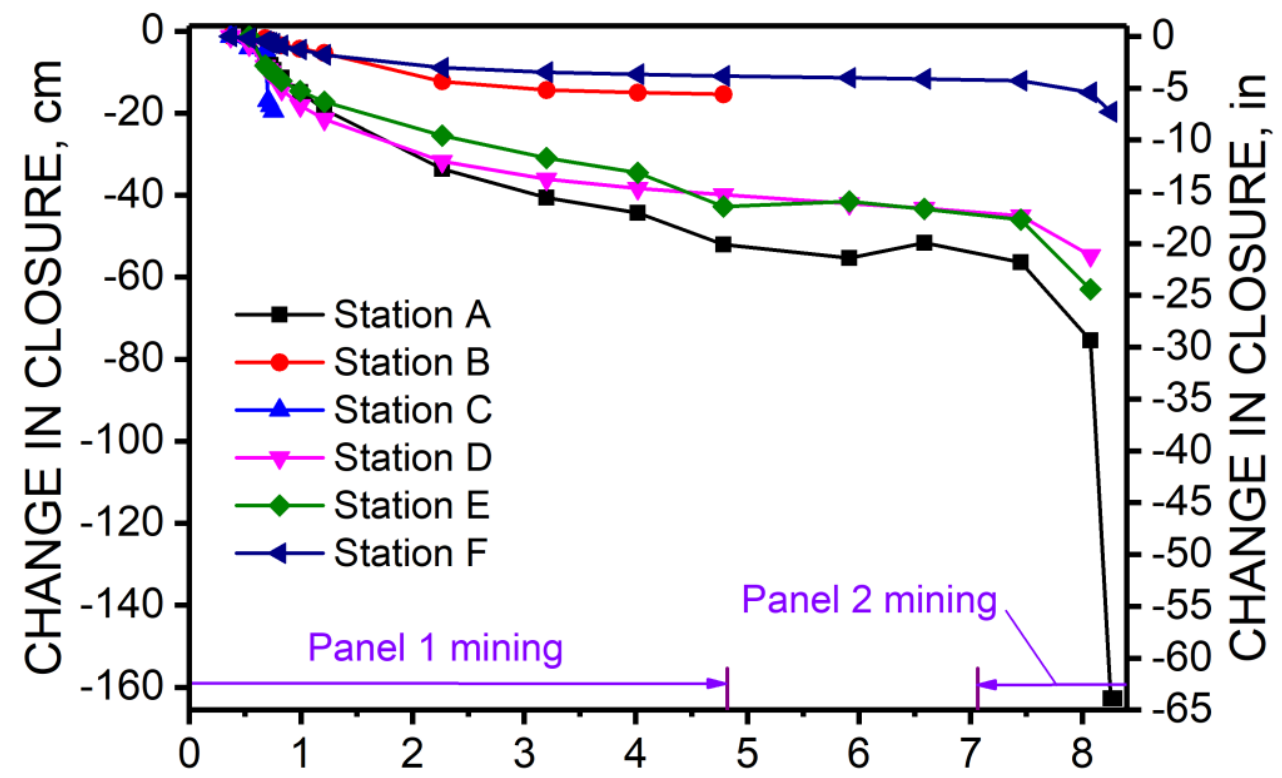

TIME SINCE ZERO TIME, $10^{3} \mathrm{hr}$

Figure C2. Entry closure with time of manually read at 2 North inby instrumentation site at Mine A. 


\section{North outby instrumentation site}

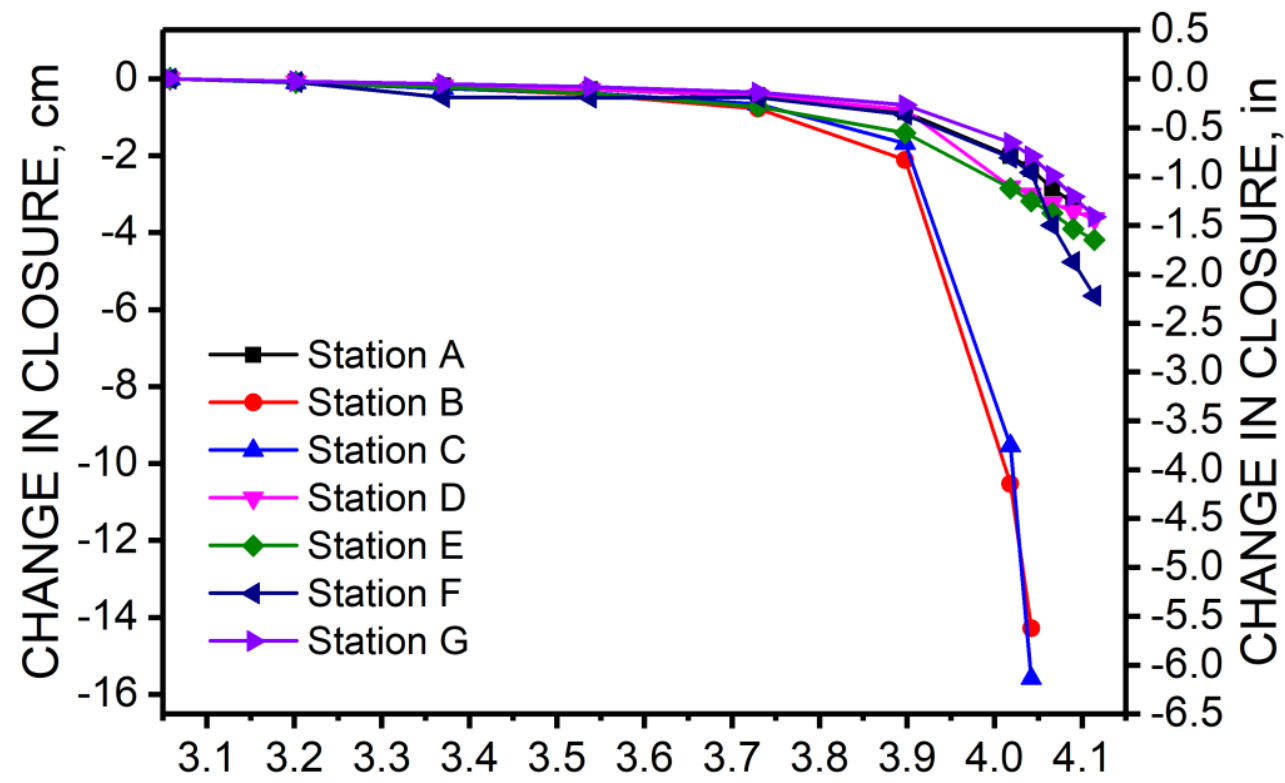

TIME SINCE ZERO TIME, $10^{3} \mathrm{hr}$

Figure C3. Entry closure with time of manually read stations at 1 North outby instrumentation site at Mine A.

2 North outby instrumentation site

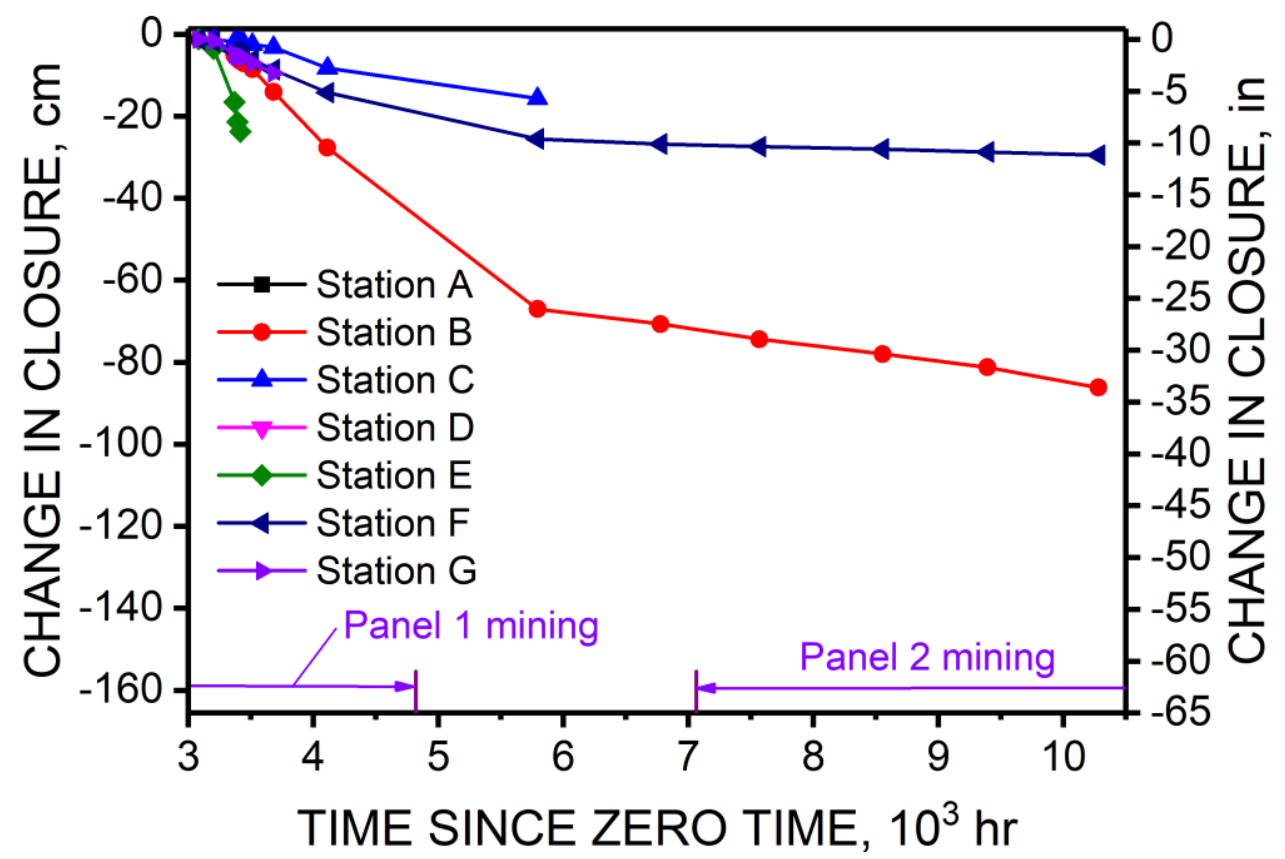

Figure C4. Entry closure with time of manually read stations at 2 North outby instrumentation site at Mine A. 

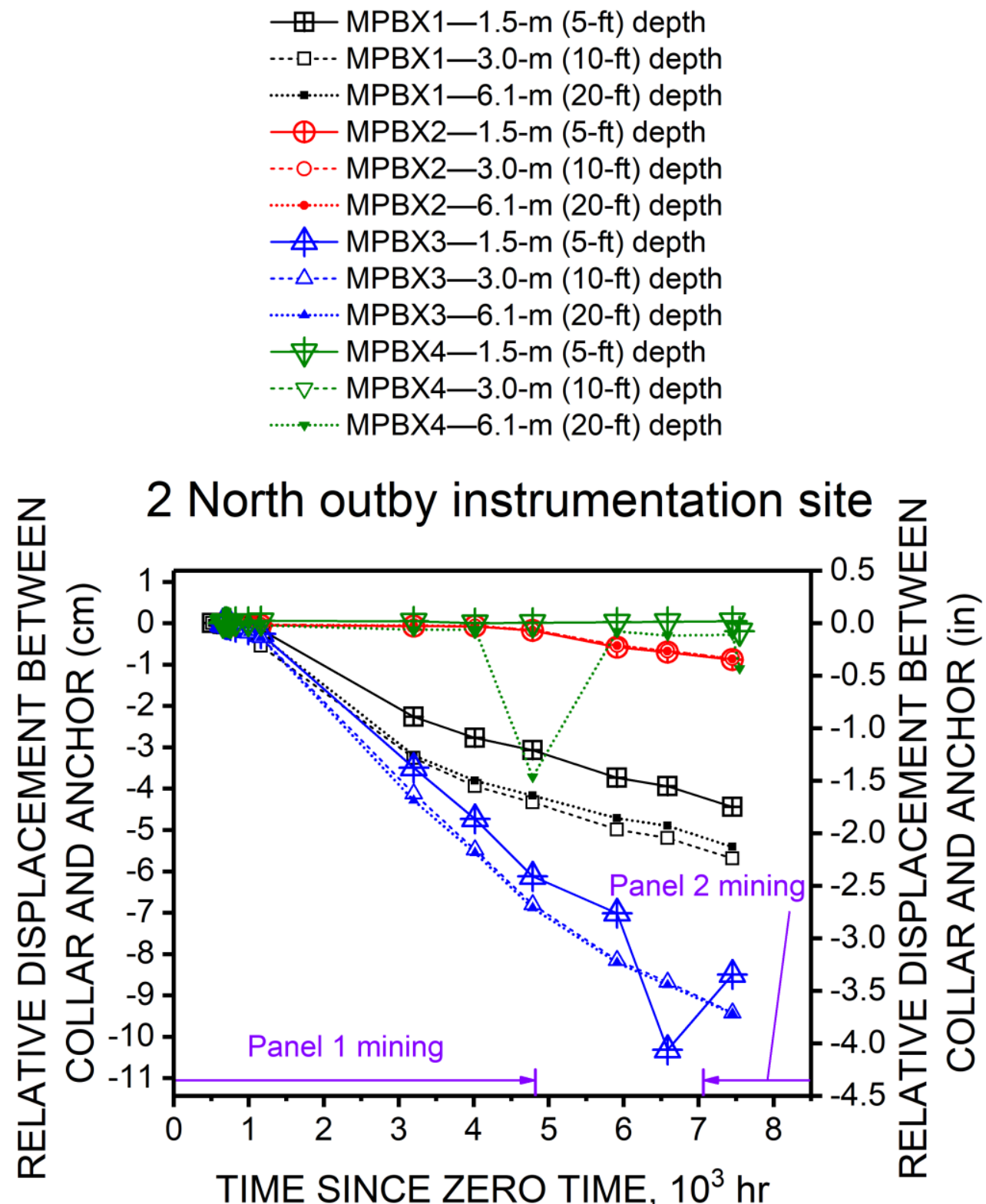

Figure C5. Relative displacements between collar and anchors in roof over time at MPBX stations at 2 North inby instrumentation site at Mine A. 
1 North string pot. extensometers set 1 :

Entry 3 , crosscut 8 , panel 1

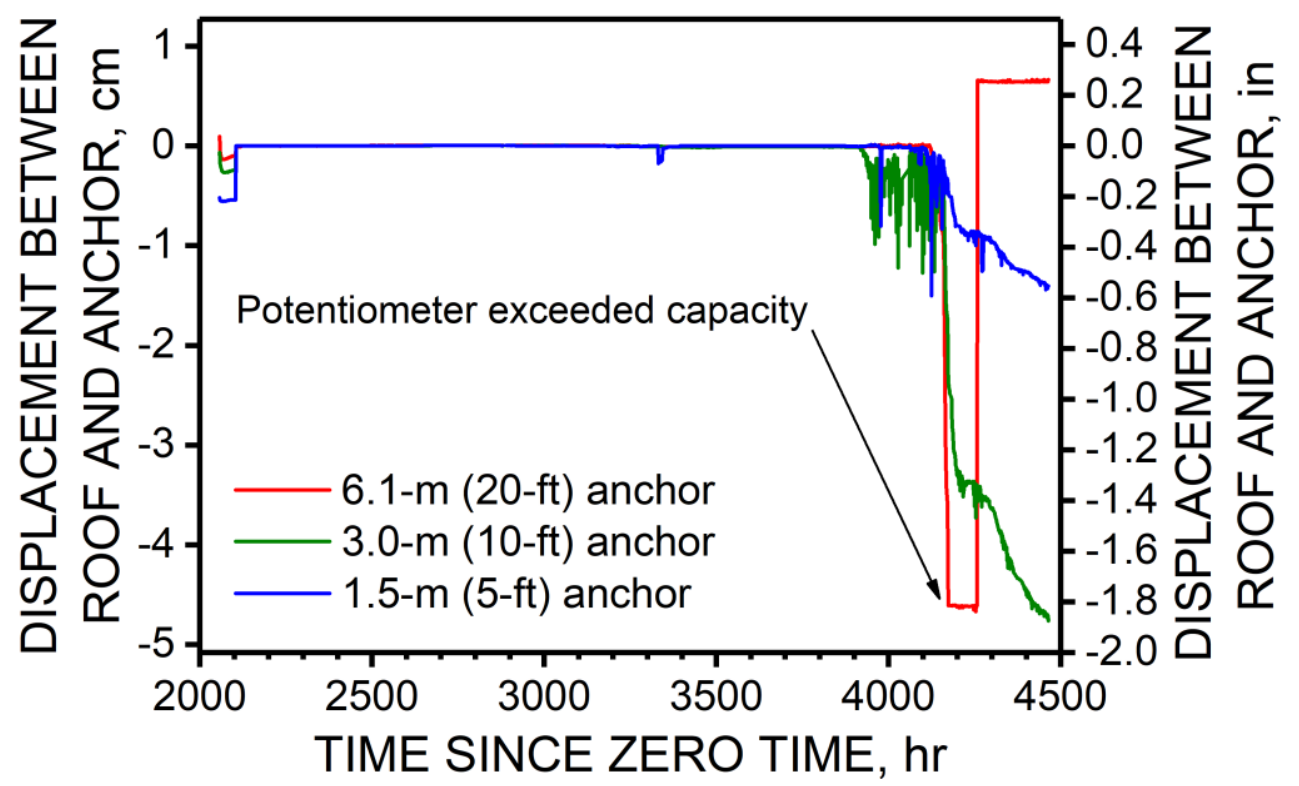

Figure C6. Relative displacements between collar and roof anchors at string potentiometer extensometer set 1 at 1 North outby instrumentation site at Mine A.

1 North string pot. extensometers set 2:

Entry 2.5 , crosscut 8 , panel 1

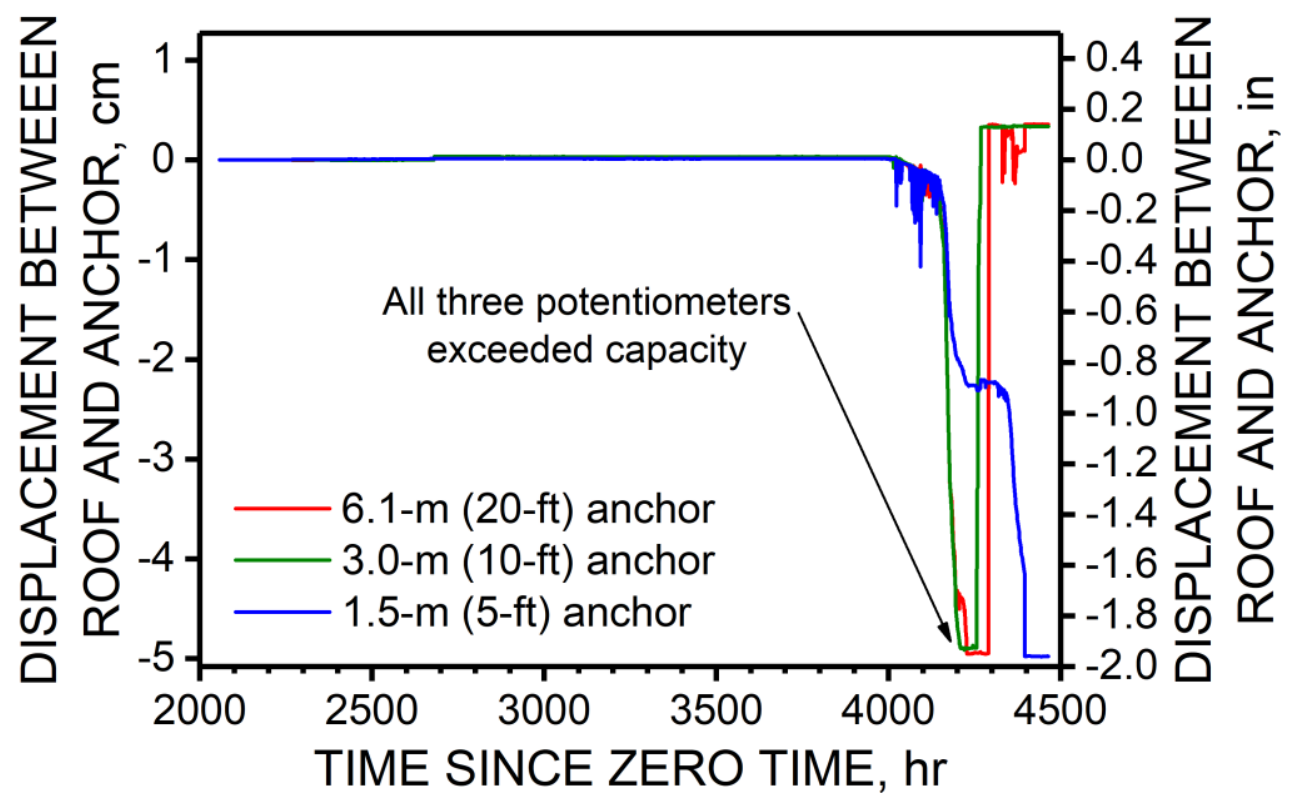

Figure C7. Relative displacements between collar and roof anchors at string potentiometer extensometer set 2 at 1 North outby instrumentation site at Mine A. 
1 North string pot. extensometers set 3 :

Entry 2, crosscut 8 , panel 1

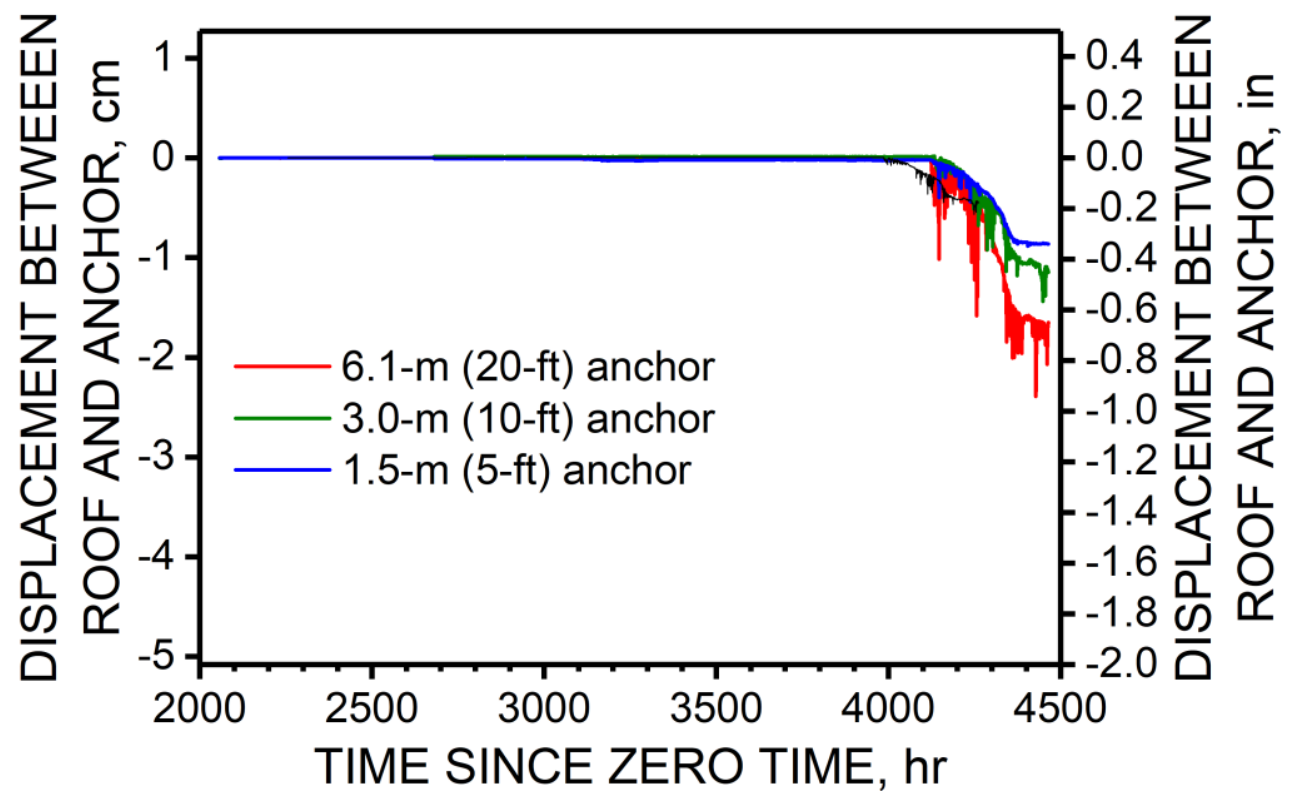

Figure C8. Relative displacements between collar and roof anchors at string potentiometer extensometer set 3 at 1 North outby instrumentation site at Mine A.

1 North string pot. extensometers set 4 :

Entry 1.5 , crosscut 8 , panel 1

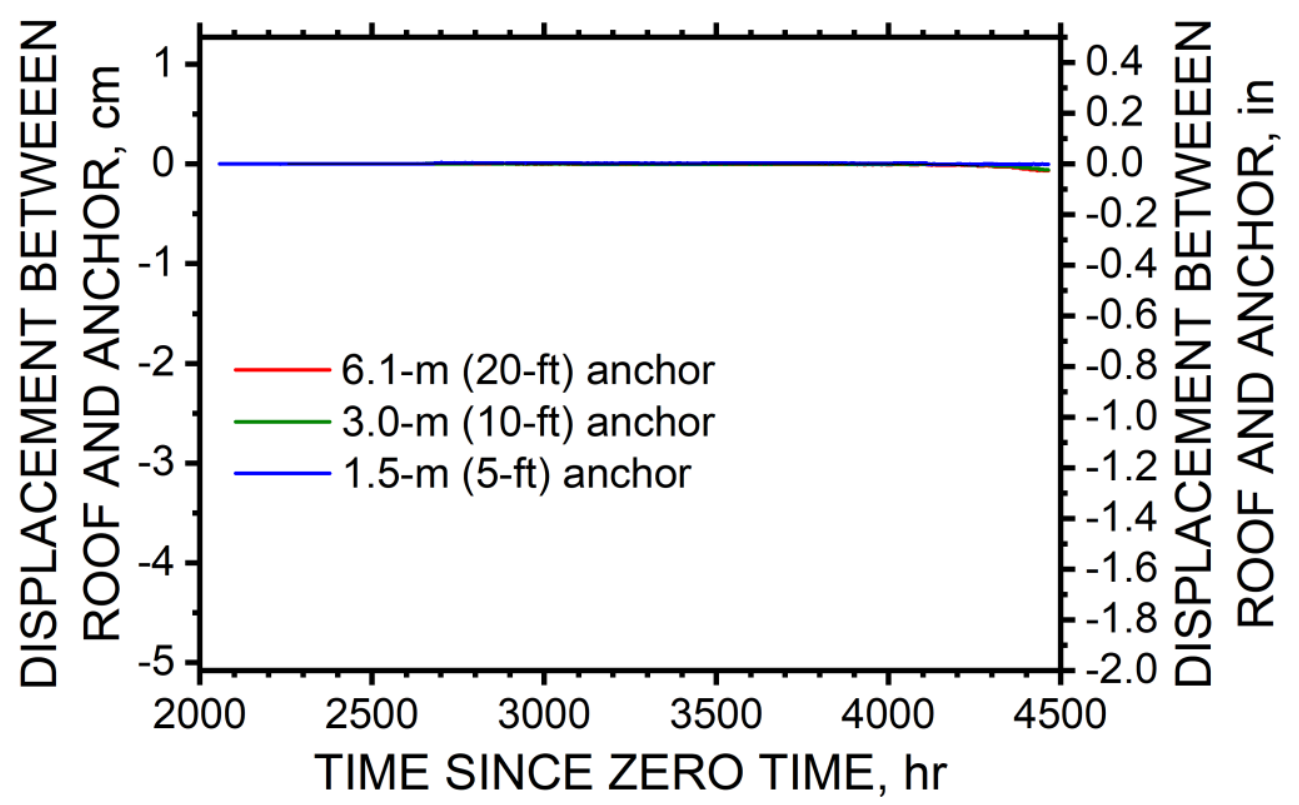

Figure C9. Relative displacements between collar and roof anchors at string potentiometer extensometer set 4 at 1 North outby instrumentation site at Mine A. 
1 North string pot. extensometers set 5 :

Entry 1 , crosscut 8 , panel 1

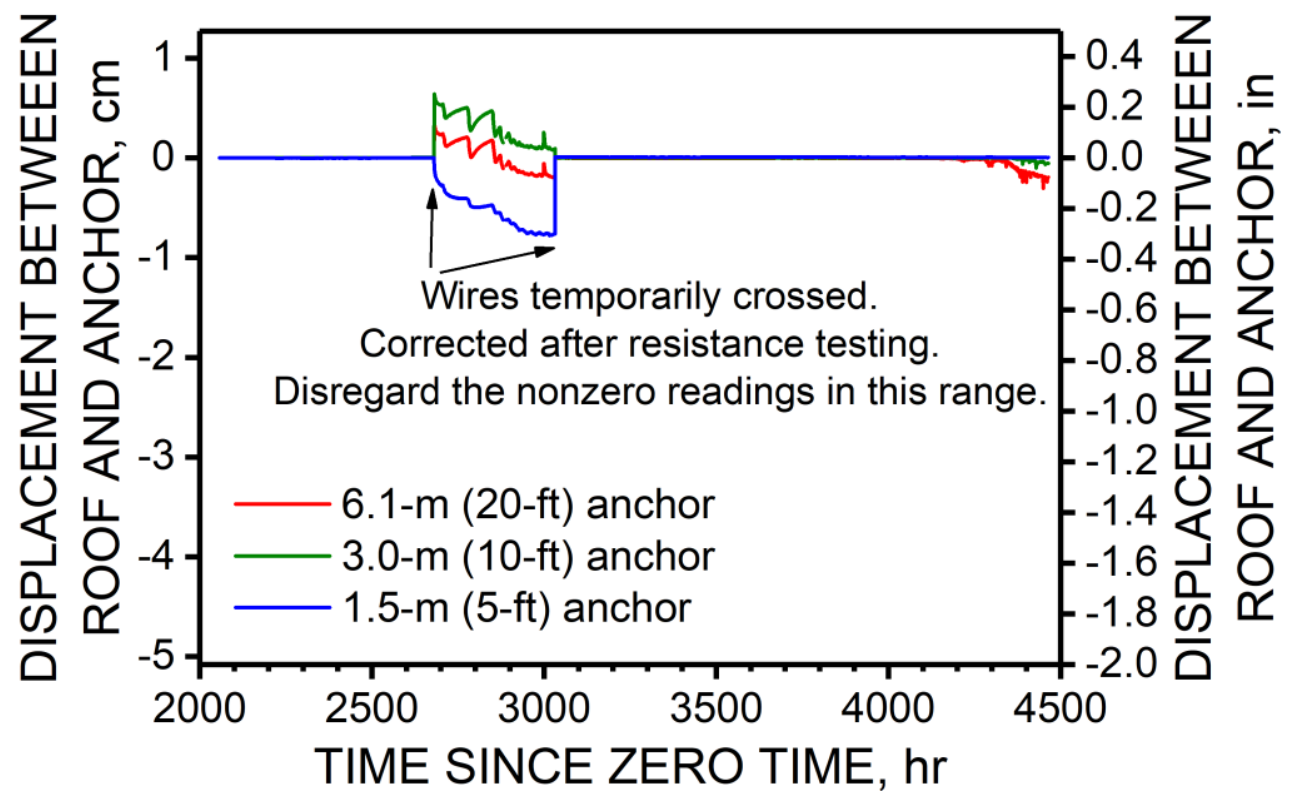

Figure C10. Relative displacements between collar and roof anchors at string potentiometer extensometer set 5 at 1 North outby instrumentation site at Mine A.

2 North string pot. extensometers set 1 :

Entry 2, crosscut 11.5 , panel 1

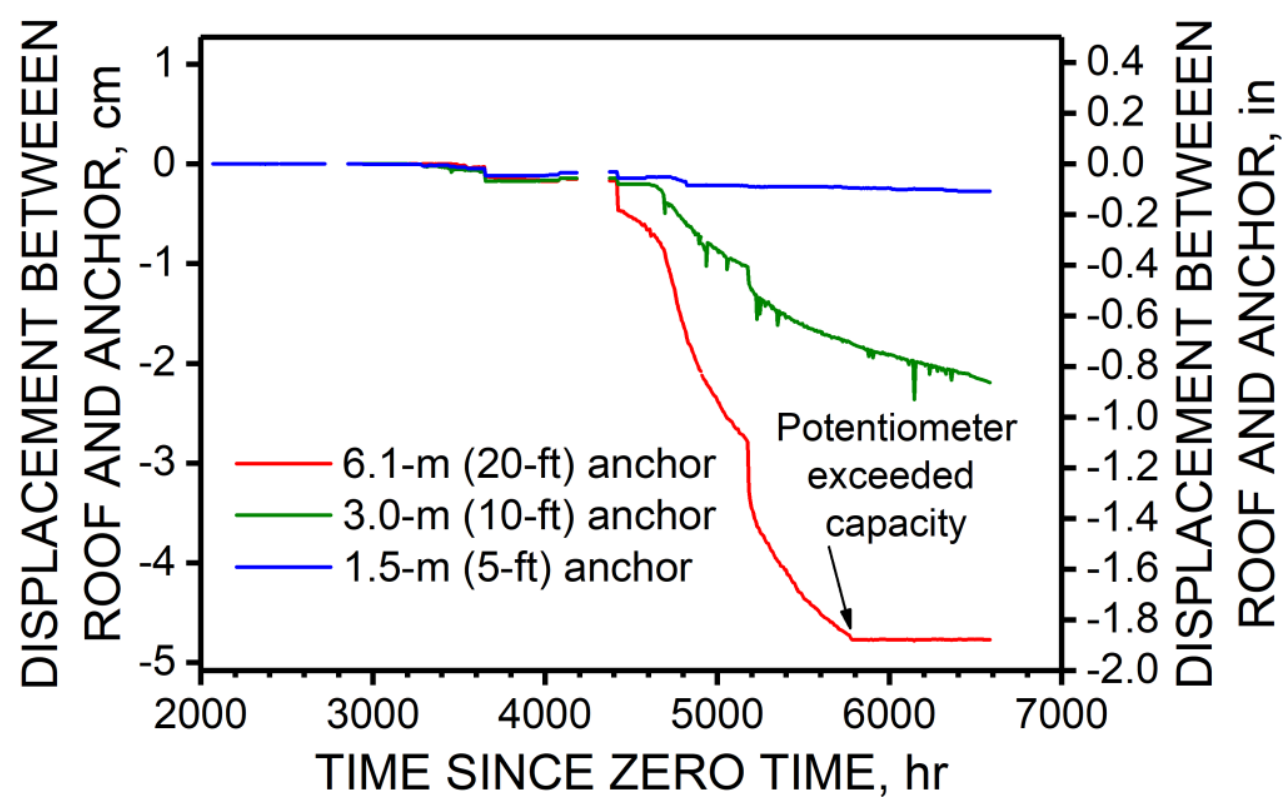

Figure C11. Relative displacements between collar and roof anchors at string potentiometer extensometer set 1 at 2 North outby instrumentation site during Panel 1 retreat at Mine A. 


\section{North string pot. extensometers set 1 : \\ Entry 2, crosscut 11.5, panel 1}

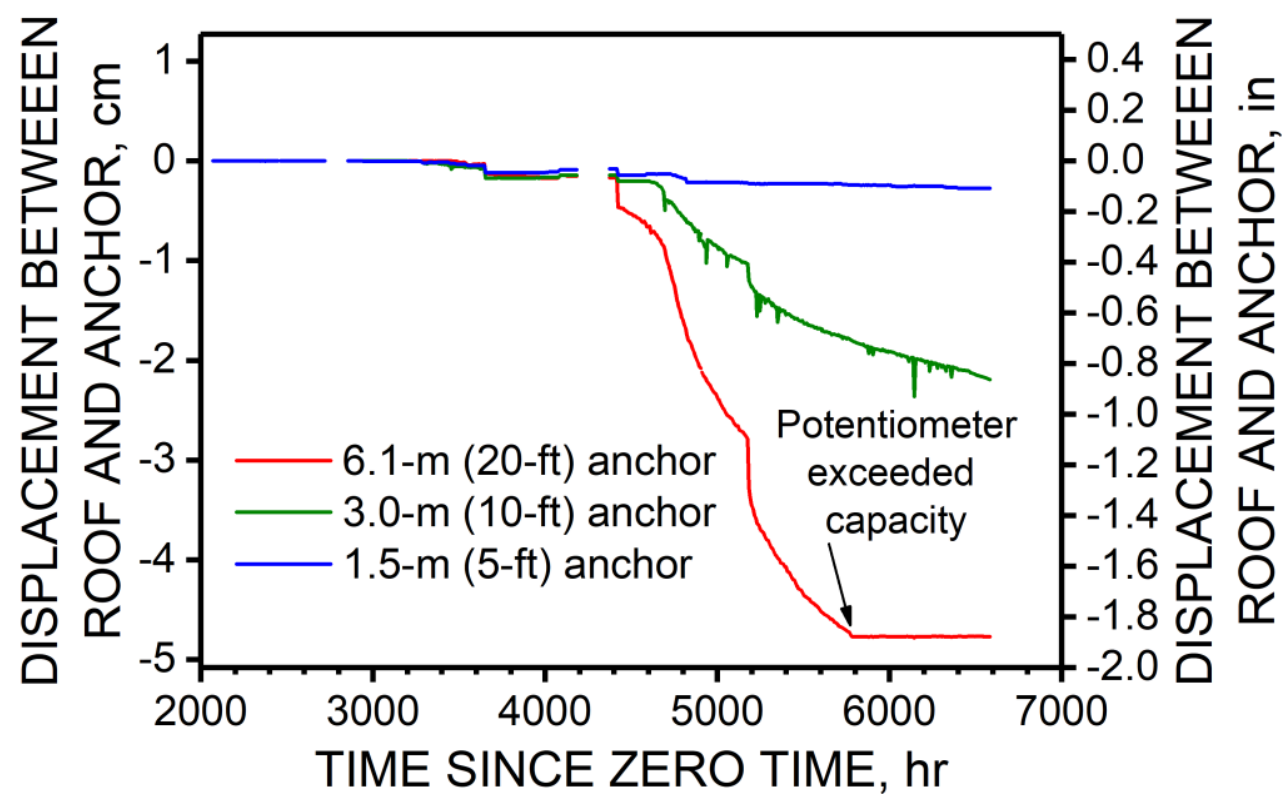

Figure $\mathbf{C 1 2}$. Relative displacements between collar and roof anchors at string potentiometer extensometer set 2 at 2 North outby instrumentation site during Panel 1 retreat at Mine A.

2 North string pot. extensometers set 3 :

Entry 2, crosscut 11, panel 1

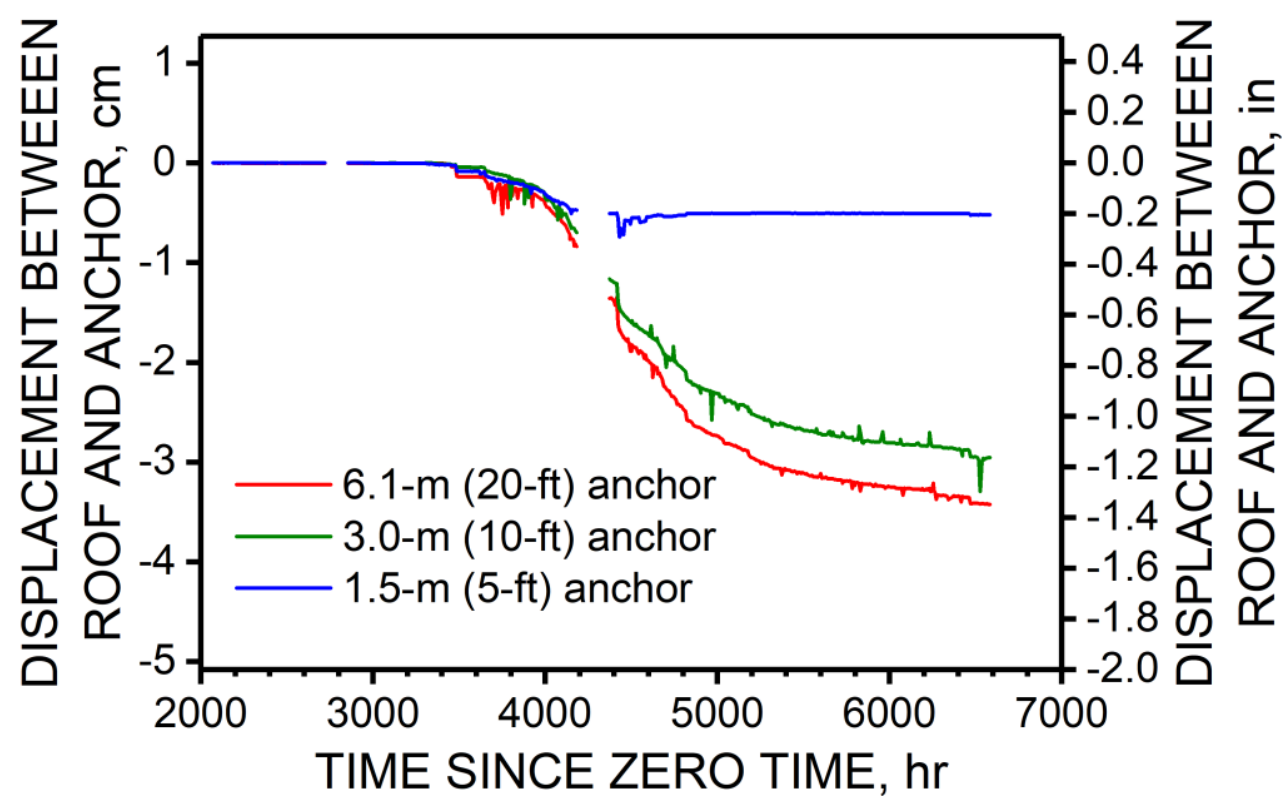

Figure C13. Relative displacements between collar and roof anchors at string potentiometer extensometer set 3 at 2 North outby instrumentation site during Panel 1 retreat at Mine A. 


\section{North string pot. extensometers set 4 : \\ Entry 2.5, crosscut 11, panel 1}

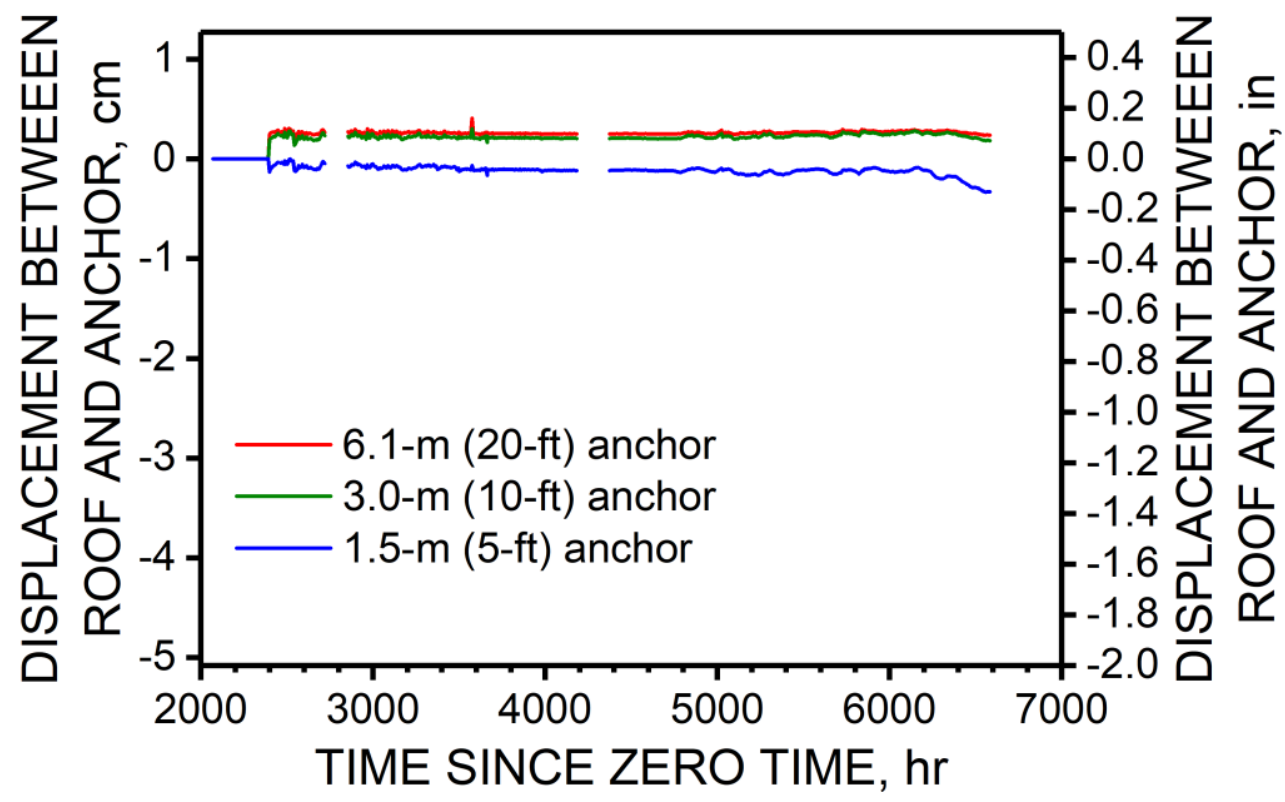

Figure C14. Relative displacements between collar and roof anchors at string potentiometer extensometer set 4 at 2 North outby instrumentation site during Panel 1 retreat at Mine $\mathbf{A}$.

2 North string pot. extensometers set 5 :

Entry 3 , crosscut 10.5 , panel 1

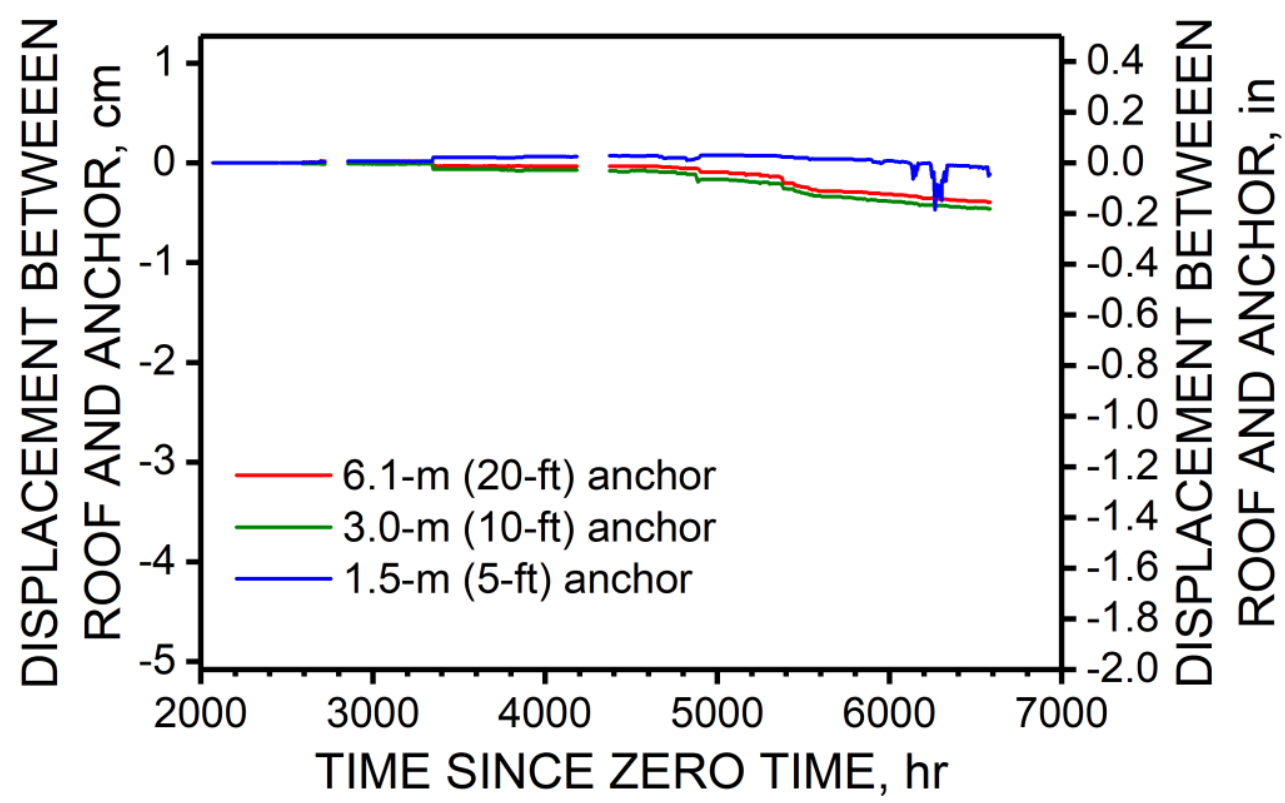

Figure C15. Relative displacements between collar and roof anchors at string potentiometer extensometer set 5 at 2 North outby instrumentation site during Panel 1 retreat at Mine A. 


\section{North string pot. extensometers set 1 : \\ Entry 2, crosscut 11.5, panel 2}

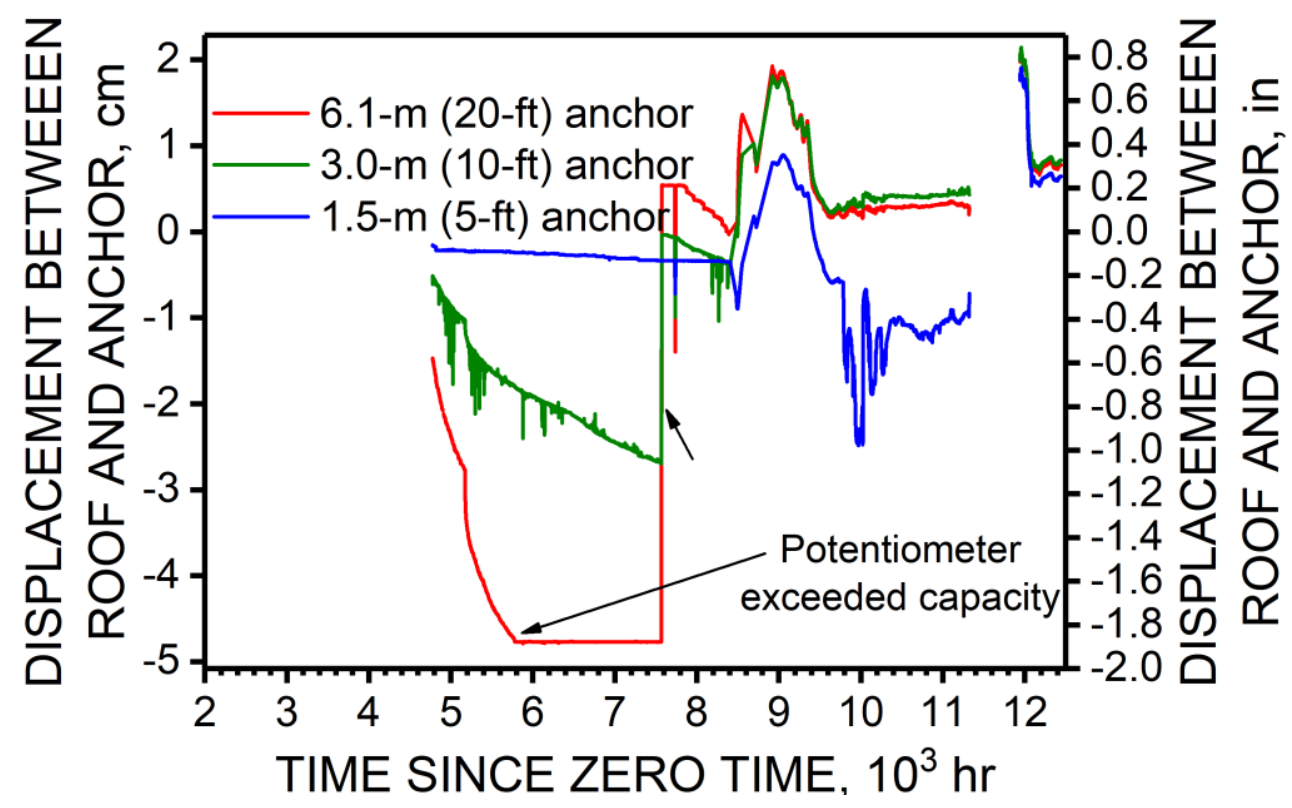

Figure $\mathbf{C}$ 16. Relative displacements between collar and roof anchors at string potentiometer extensometer set 1 at 2 North outby instrumentation site during Panel 2 retreat at Mine $A$.

2 North string pot. extensometers set 2 :

Entry 1.5 , crosscut 11 , panel 2

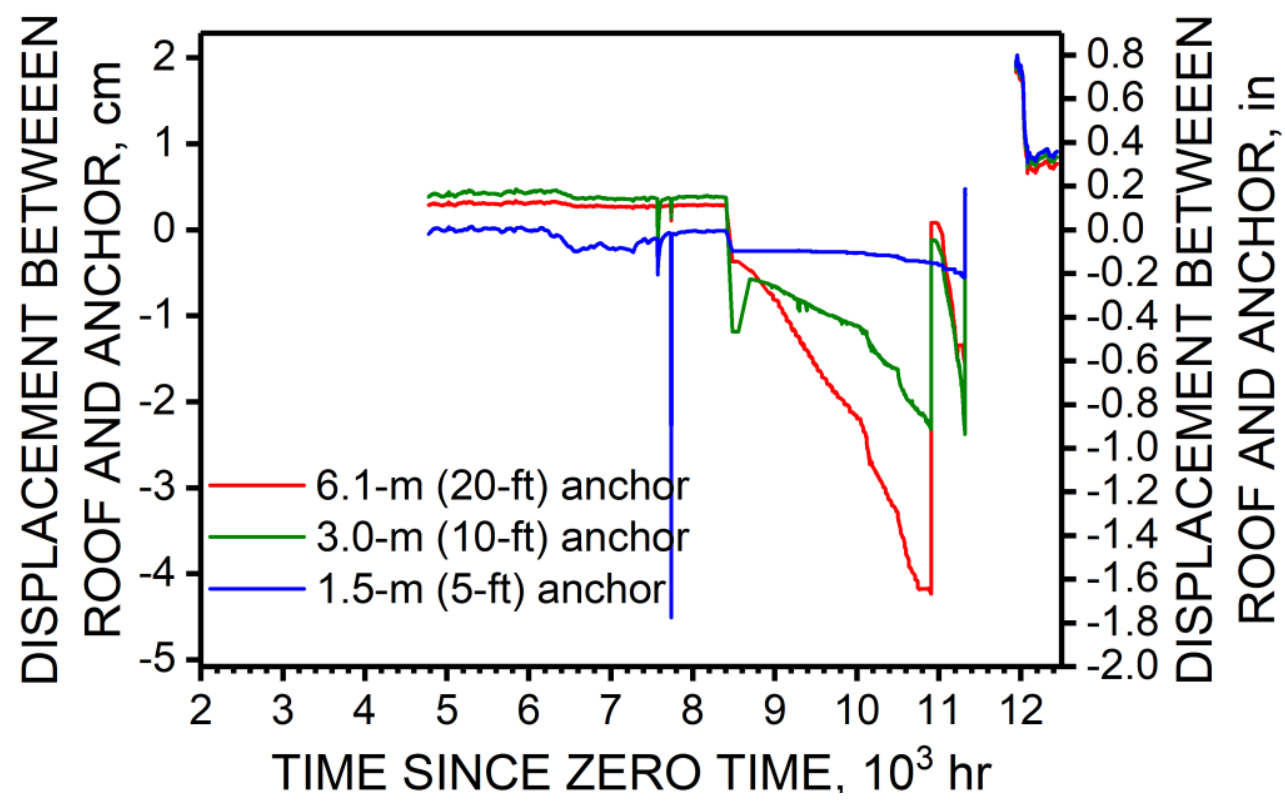

Figure C17. Relative displacements between collar and roof anchors at string potentiometer extensometer set 2 at 2 North outby instrumentation site during Panel 2 retreat at Mine A. 


\section{North string pot. extensometers set 3 : \\ Entry 2, crosscut 11, panel 2}

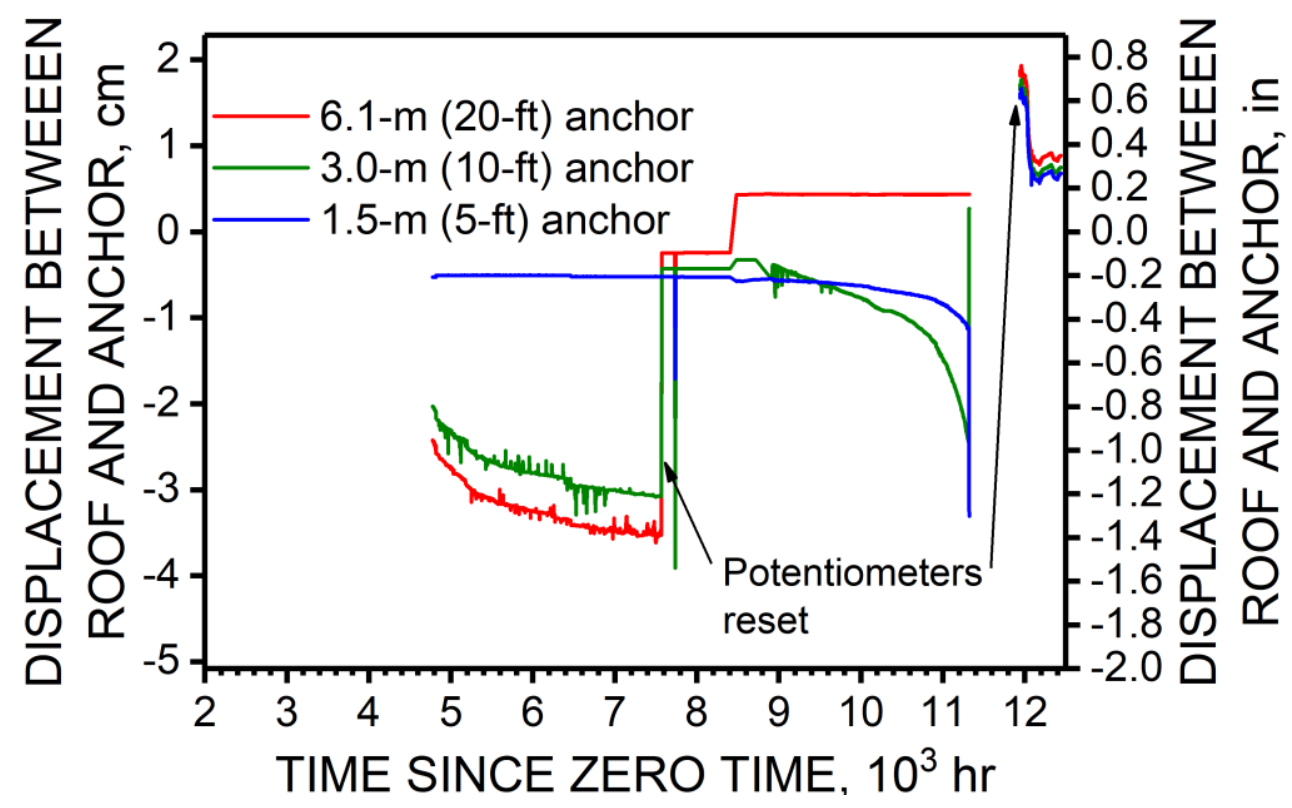

Figure C18. Relative displacements between collar and roof anchors at string potentiometer extensometer set 3 at 2 North outby instrumentation site during Panel 2 retreat at Mine A.

2 North string pot. extensometers set 4 :

Entry 2.5 , crosscut 11 , panel 2

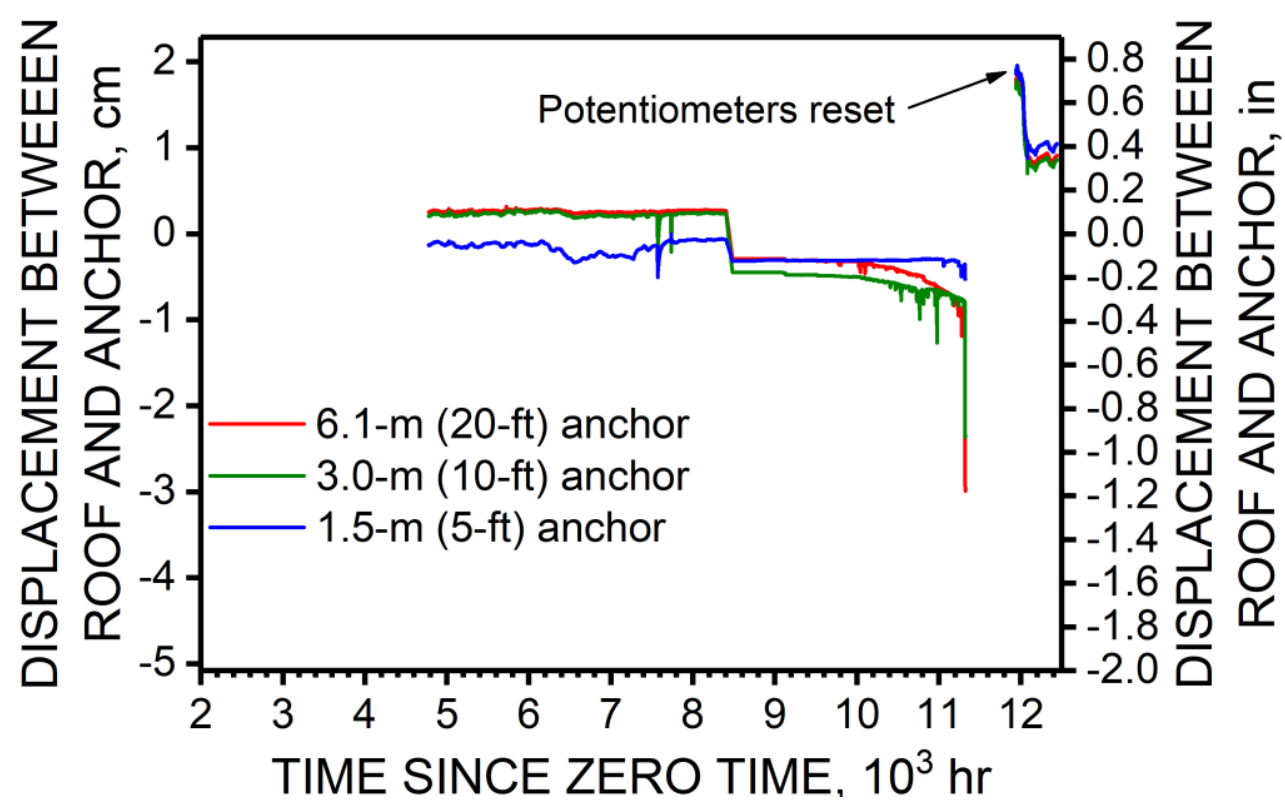

Figure C19. Relative displacements between collar and roof anchors at string potentiometer extensometer set 4 at 2 North outby instrumentation site during Panel 2 retreat at Mine $A$. 


\section{North string pot. extensometers set 5 : \\ Entry 3, crosscut 10.5, panel 2}

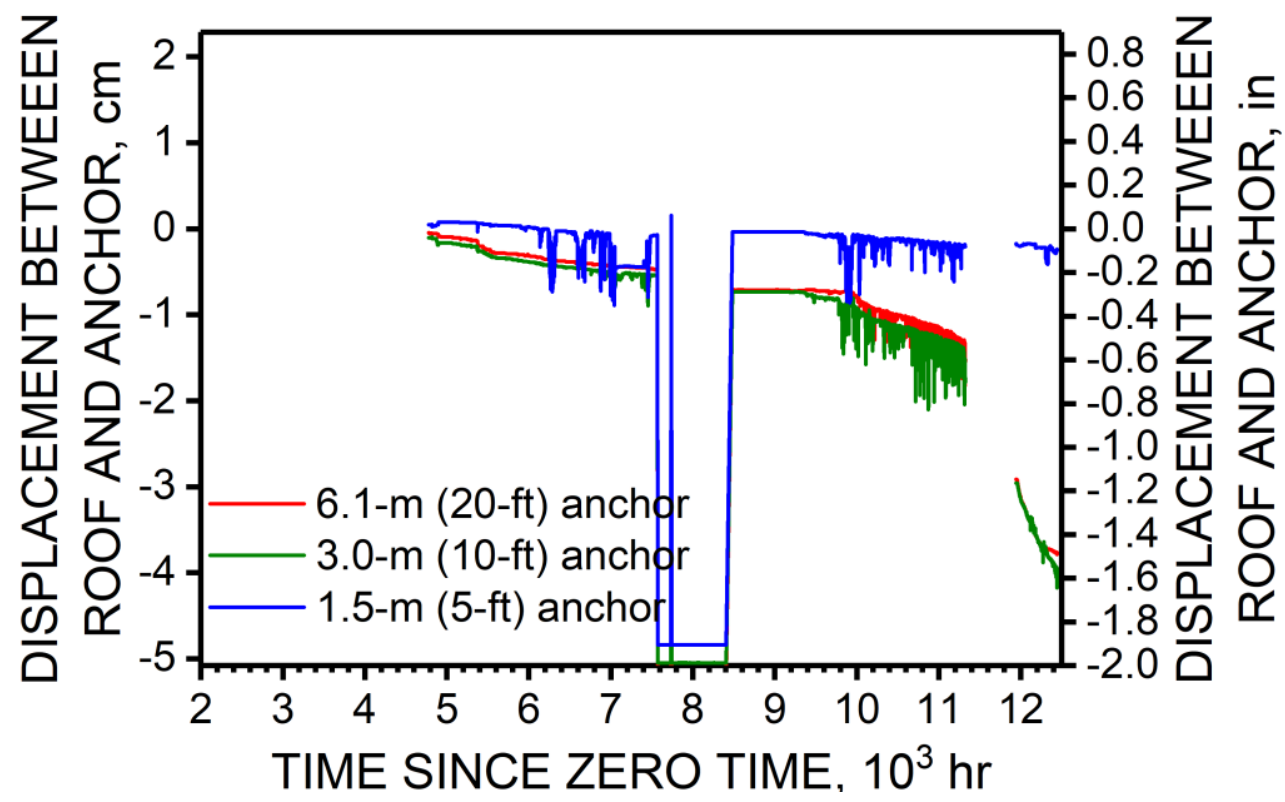

Figure C20. Relative displacements between collar and roof anchors at string potentiometer extensometer set 5 at 2 North outby instrumentation site during Panel 2 retreat at Mine $\mathbf{A}$. 


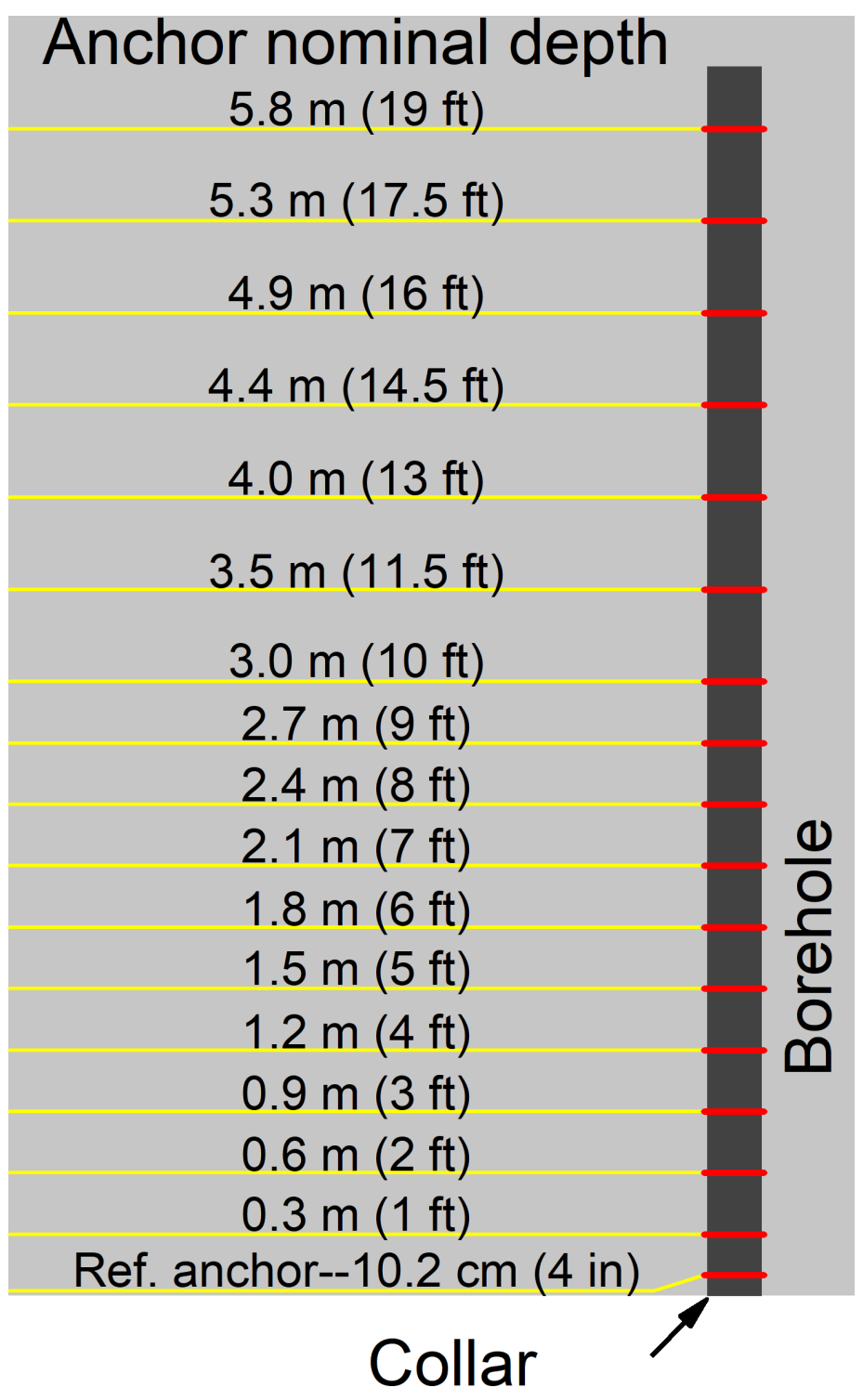

Figure C21. Nominal depths of anchors installed for sonic probe instruments used in this study at 1 North outby and 2 North outby instrumentation sites at Mine A. 
Sonic probe, 1 North, entry 2 at crosscut 8

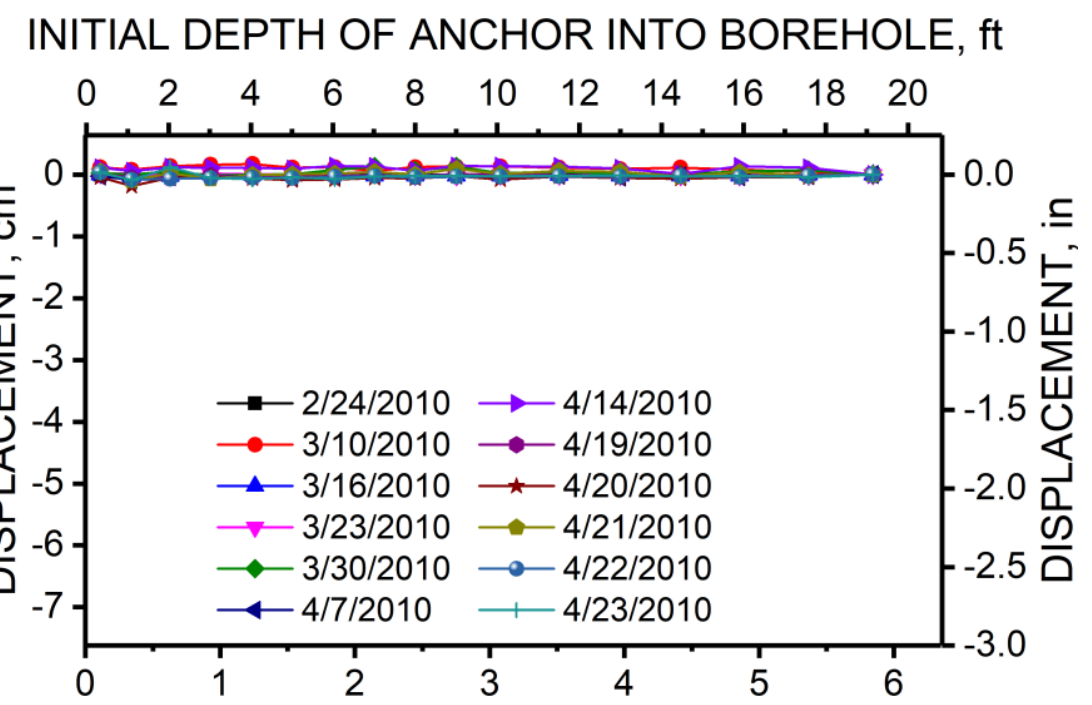

INITIAL DEPTH OF ANCHOR INTO BOREHOLE, $m$

Figure C22. Displacements versus initial depth of anchor into borehole, relative to deepest anchor. Measured with sonic probe on various dates in 1 North gate roads in entry 2 at crosscut 8 at Mine A.

Sonic probe, 1 North, crosscut 8 between entries 2 and 3

INITIAL DEPTH OF ANCHOR INTO BOREHOLE, $\mathrm{ft}$

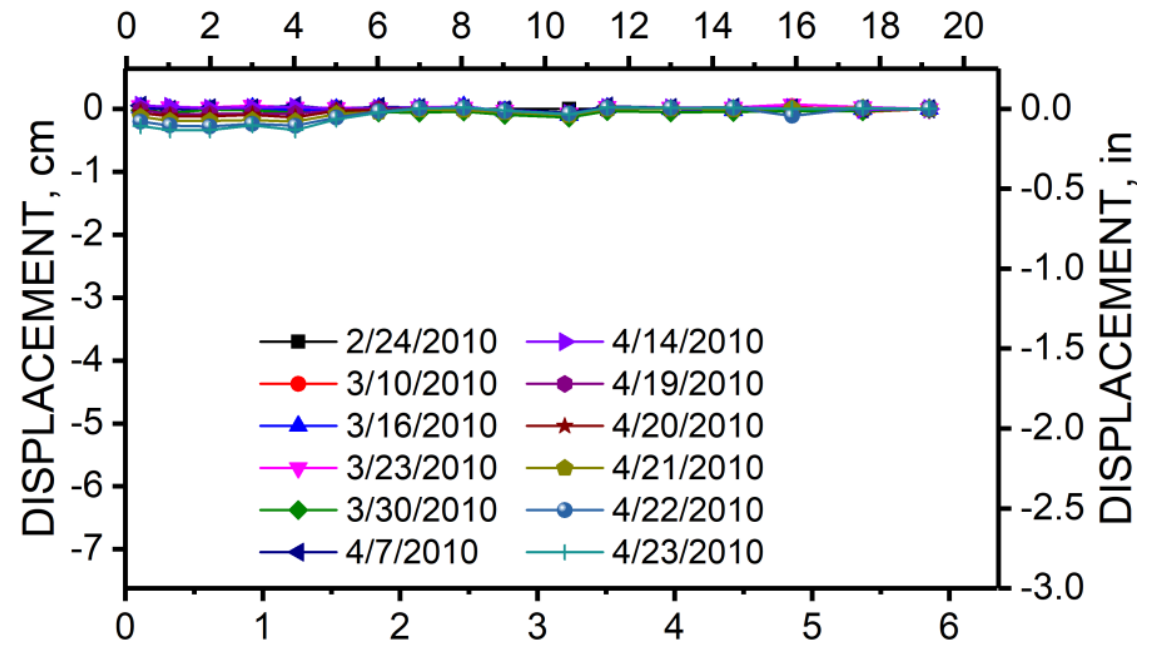

INITIAL DEPTH OF ANCHOR INTO BOREHOLE, $m$

Figure C23. Displacements versus initial depth of anchor into borehole, relative to deepest anchor. Measured with sonic probe on various dates in 1 North gate roads in crosscut 8 between entries 2 and 3 at Mine $A$. 
Sonic probe, 2 North, entry 3 at crosscut 10

INITIAL DEPTH OF ANCHOR INTO BOREHOLE, ft

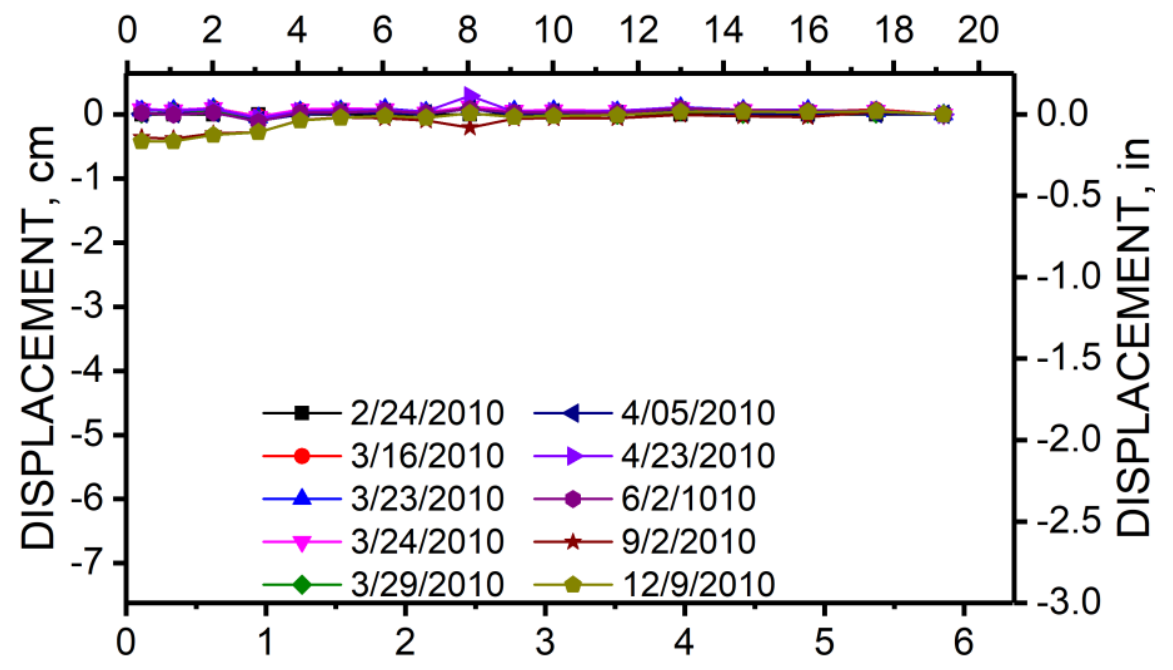

INITIAL DEPTH OF ANCHOR INTO BOREHOLE, $m$

Figure C24. Displacements versus initial depth of anchor into borehole, relative to deepest anchor. Measured with sonic probe on various dates in 2 North gate roads in entry 3 at crosscut 10 at Mine A.

Sonic probe, 2 North, entry 3 between crosscuts 9 and 10 INITIAL DEPTH OF ANCHOR INTO BOREHOLE, $\mathrm{ft}$

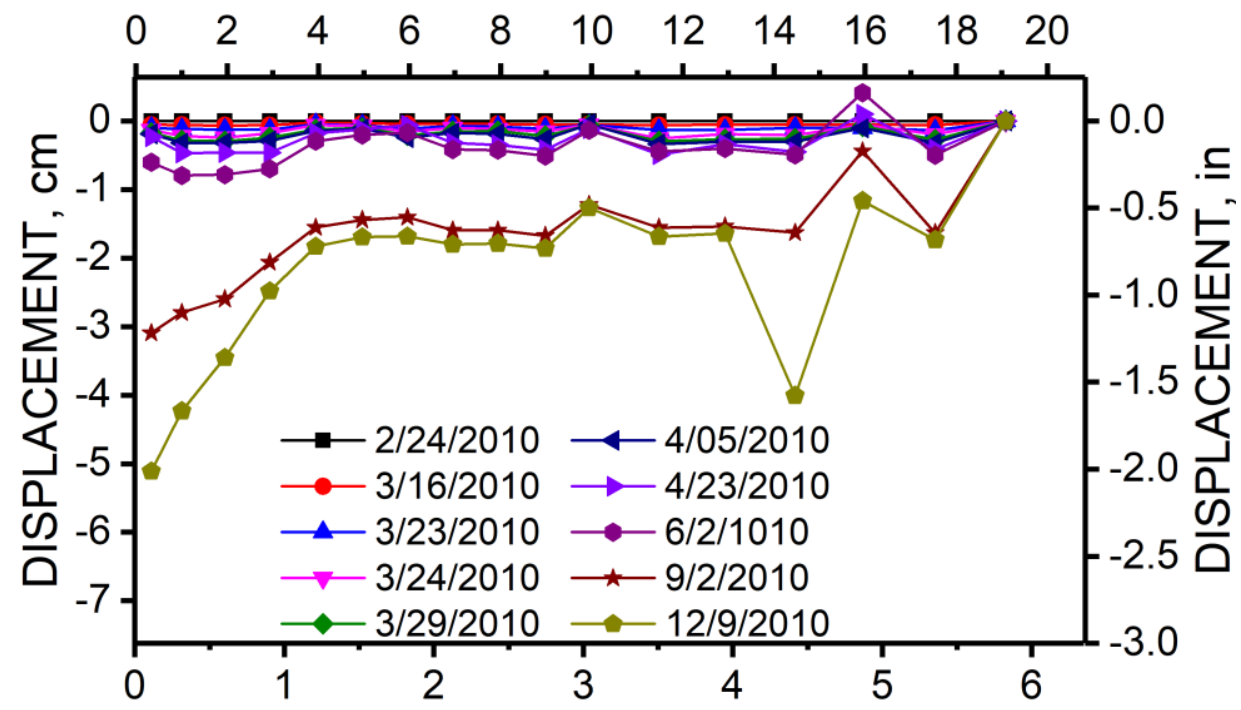

INITIAL DEPTH OF ANCHOR INTO BOREHOLE, $m$

Figure C25. Displacements versus initial depth of anchor into borehole, relative to deepest anchor. Measured with sonic probe on various dates in 2 North gate roads in entry 3 between crosscuts 9 and 10 at Mine A. 


\section{Appendix D: Mine A-Ground Condition Surveys}

\section{Description}

Walking ground condition surveys were conducted in parts of the 1 North gate roads during mining of Panel 1. They were also done in entries 2 and 3 or the 2 North gate roads during mining of Panels 1 and 2.

Figures D1-D3 show average roof, rib, and floor ground condition ratings, respectively, by location along the gate roads in all three entries in 1 North. Ratings were given as average ratings of the entire distance between crosscuts and also at the intersection of some crosscuts and entries. The survey shows generally good conditions of roof, ribs, and floor, but most deterioration over time occurred in the roof and ribs, with only very slight changes in the floor.

Figures D4-D7 show ground condition ratings along entry 2 of 2 North, including average roof, average rib, maximum rib, and average floor ratings, respectively, with location along the entry. Figures D8-D11 show the same respective ratings along entry 3 of 2 North with location along the entry. In general, these eight figures support the following points:

- The earliest ratings seem to form a baseline that may reflect the effect of different geologic structures, such as a stiff member or fault. For example, the baseline ratings in entry 2 of 2 North show worse roof conditions from crosscut 14 to 18 , worse rib conditions from crosscuts 9 to 17 and from crosscuts 24 to 28 , and worse floor ratings from crosscuts 11 to 17 and from crosscuts 22 to 26 . These ranges of worse baseline conditions have some overlap in the roof, ribs, and floor around the area of a seismic event that occurred, as mentioned in the next bullet. Although not directly indicating structure, the baseline ratings probably suggest areas that may have some degree of increased risk of hazard. However, more case studies would be necessary to evaluate the usefulness of such information in assessing possible structure changes or any increased risk.

- A mining-induced seismic event on February 17, 2011, caused significant deterioration of the roof, ribs, and floor as evidenced by ground condition ratings where surveying was possible after that event.

- Roof ratings remained mostly the same until the seismic event occurred.

- Rib ratings, both average and maximum, and floor ratings tended to increase, beginning after some point with time that presumably corresponds with proximity of the face. However, the infrequent nature of the surveys fails to make this point a strong conclusion.

In these eight figures (D4 to D11), the area of significant damage caused by the seismic event is noted. Also noted is an anomalous zone that was not consistent in ratings with most of the rest of the gate roads. With time, that zone grew, which is shown as the "extended anomalous zone" in the figures. This zone appeared to have some correlation to an intersection of a fault with the gate roads. Another anomalous zone, between crosscuts 24 and 28, is not noted in the figures, but ratings were increased with respect to the rest of the gate roads, including the roof, and appeared to have correlation with intersecting faults. The ground conditions ratings of this zone were rated as an average of the entire zone, for which ratings appear in Figure 36 in the main body of this report. 


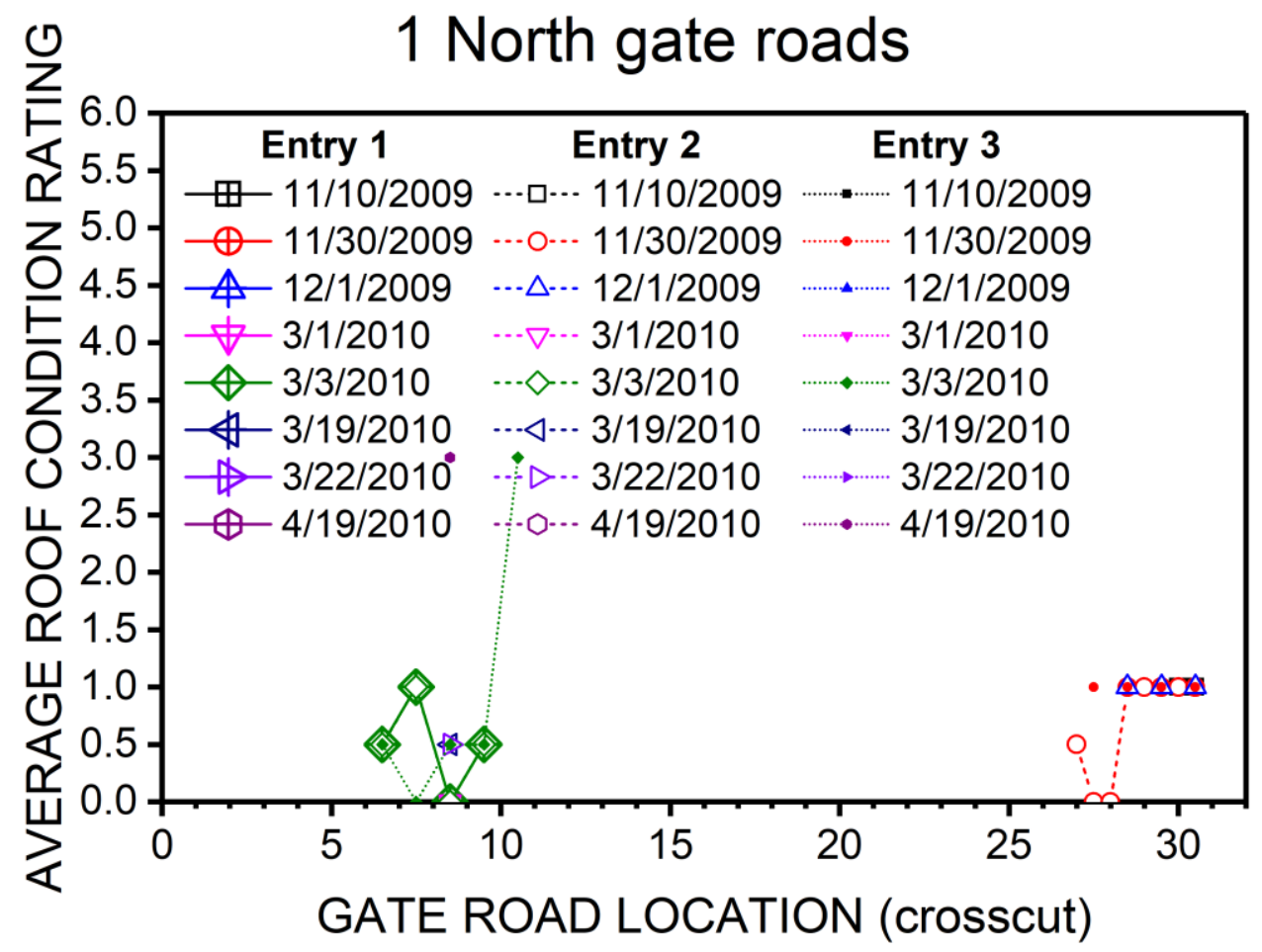

Figure D1. Results of walking survey of average roof condition ratings by location in the 1 North gate roads at Mine $A$.

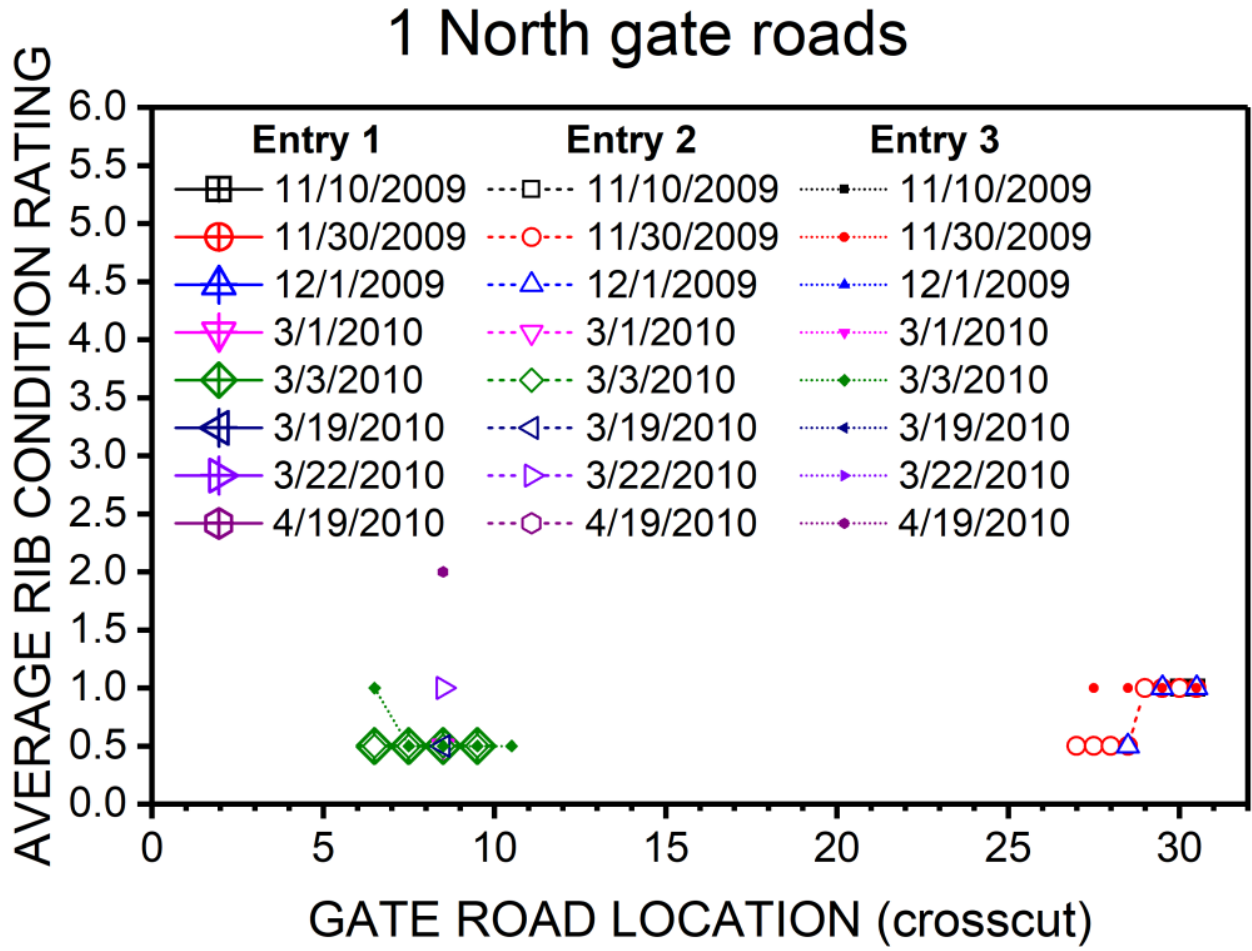

Figure D2. Results of walking survey of average rib condition ratings by location in the 1 North gate roads at Mine $A$. 


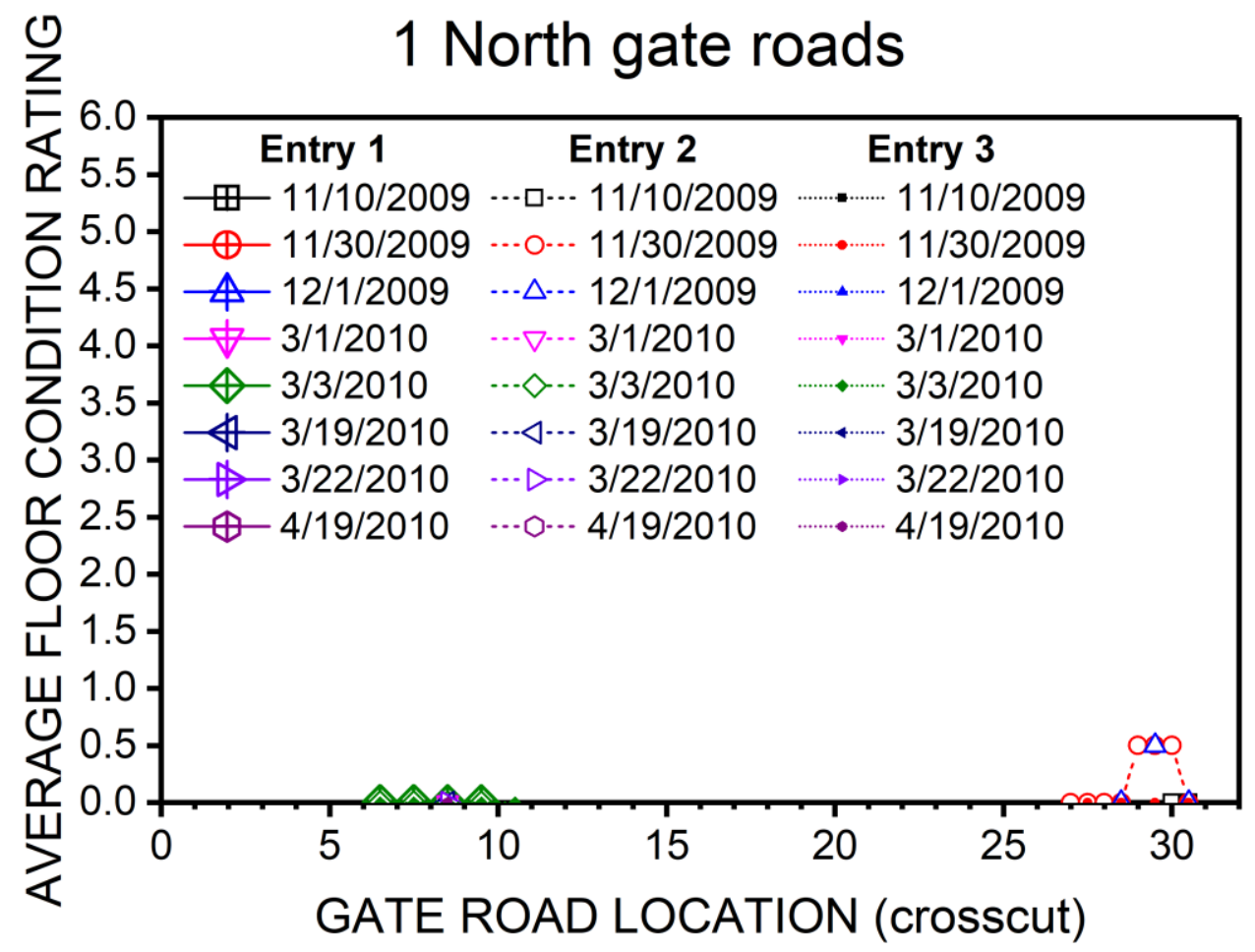

Figure D3. Results of walking survey of average floor condition ratings by location in the 1 North gate roads at Mine $A$.

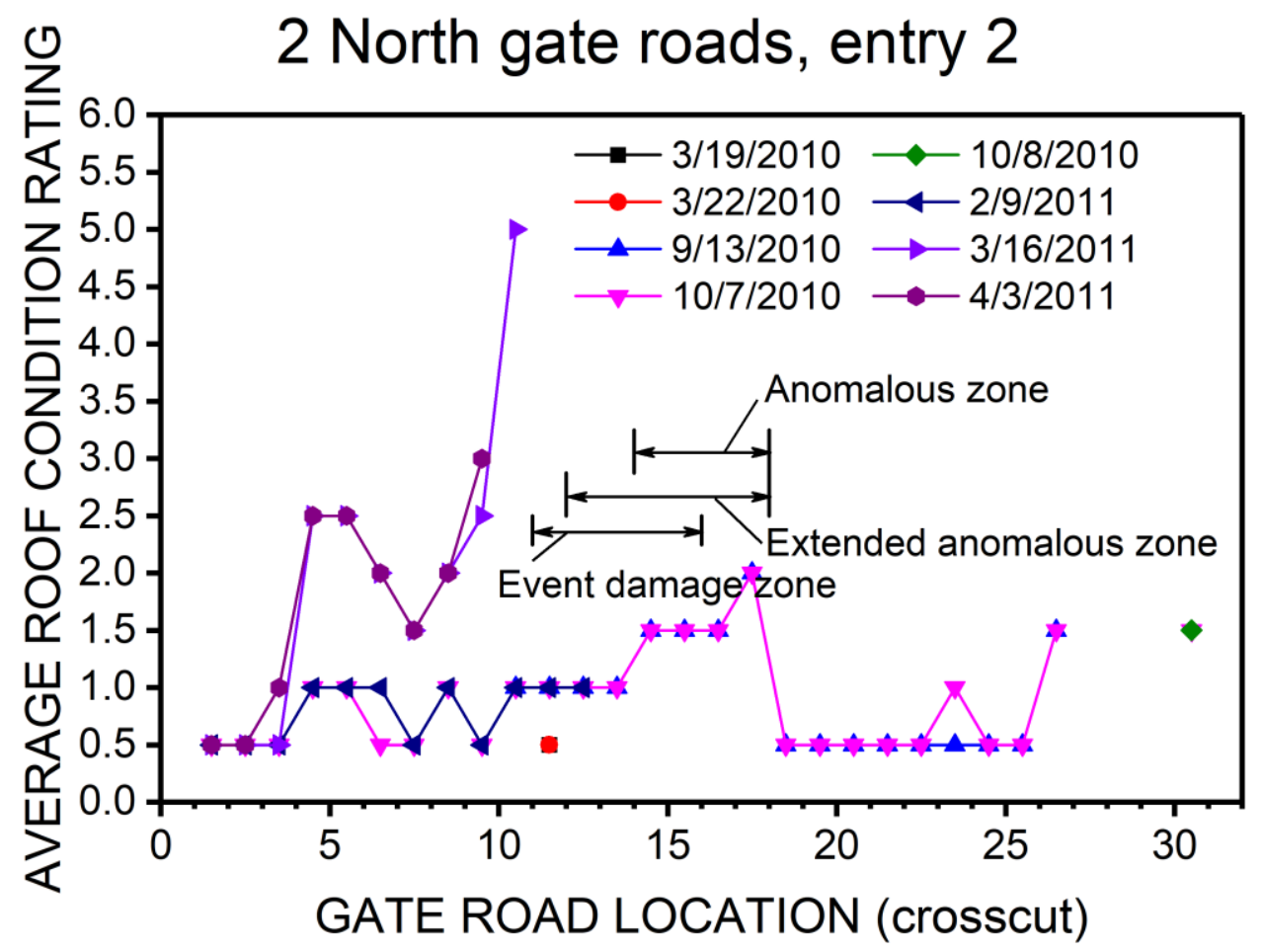

Figure D4. Results of walking survey of average roof condition ratings by location in entry 2 of the 2 North gate roads at Mine $A$. 


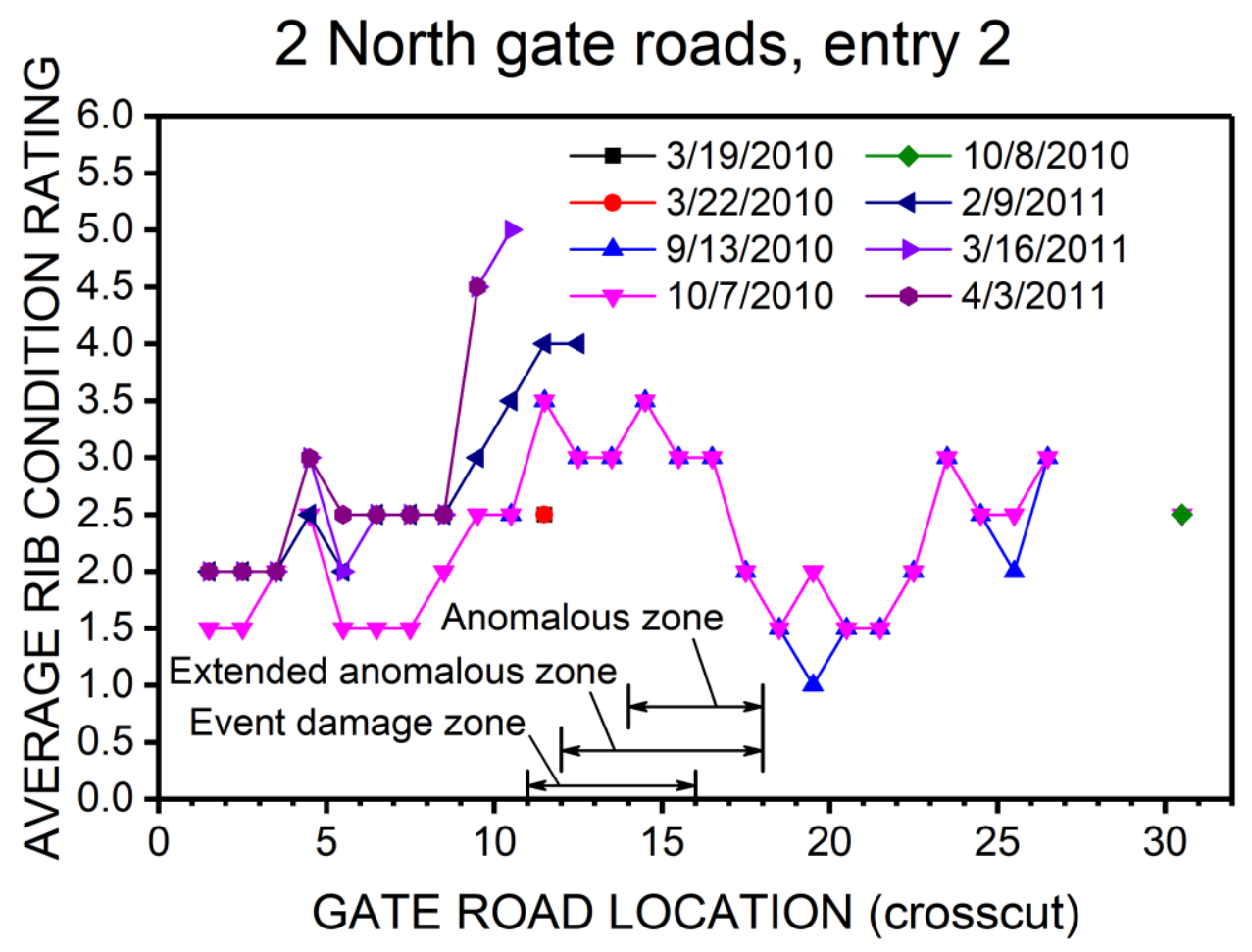

Figure D5. Results of walking survey of average rib condition ratings by location in entry 2 of the 2 North gate roads at Mine $A$.

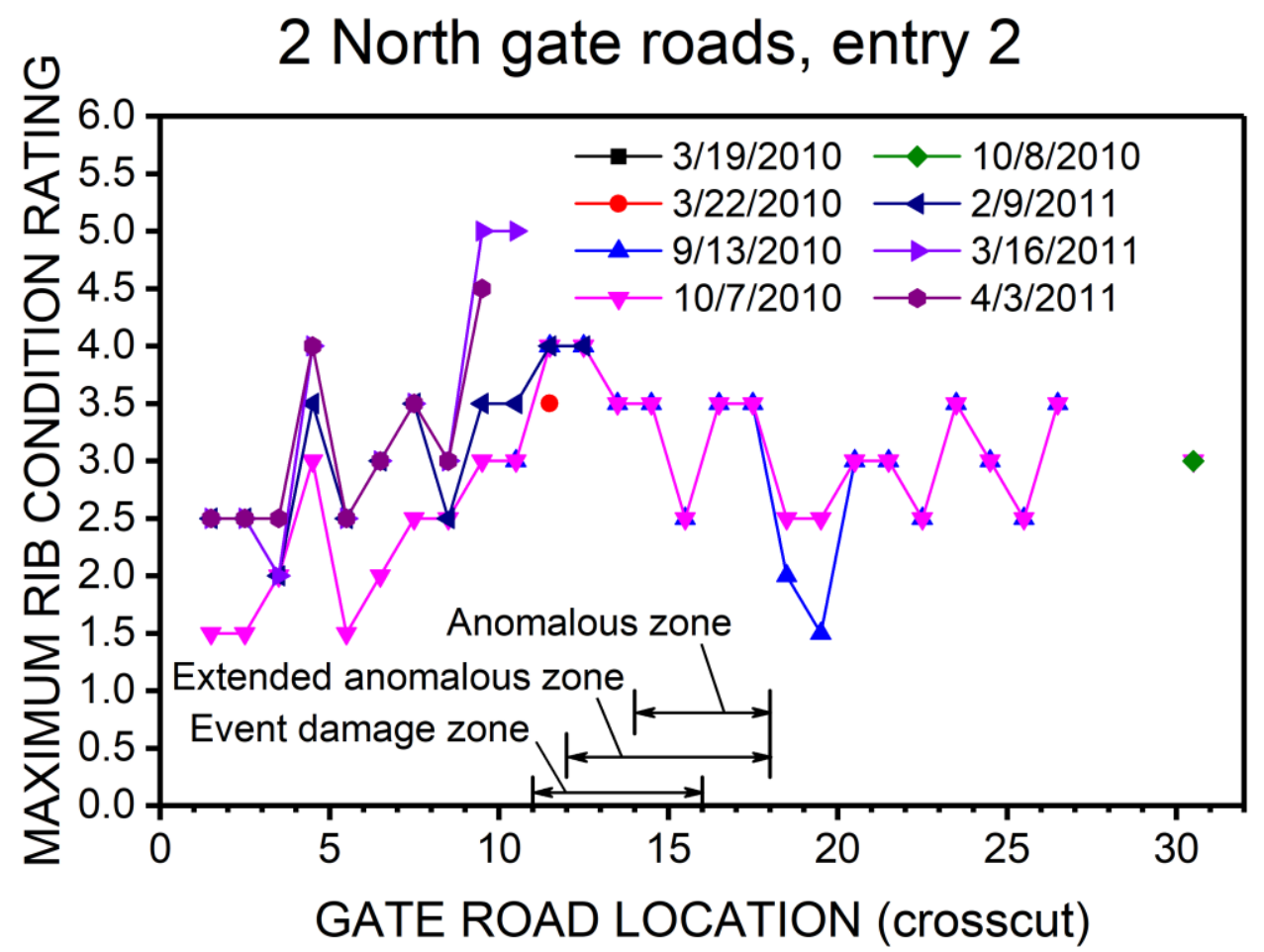

Figure D6. Results of walking survey of maximum rib condition ratings by location in entry 2 of the 2 North gate roads at Mine A. 


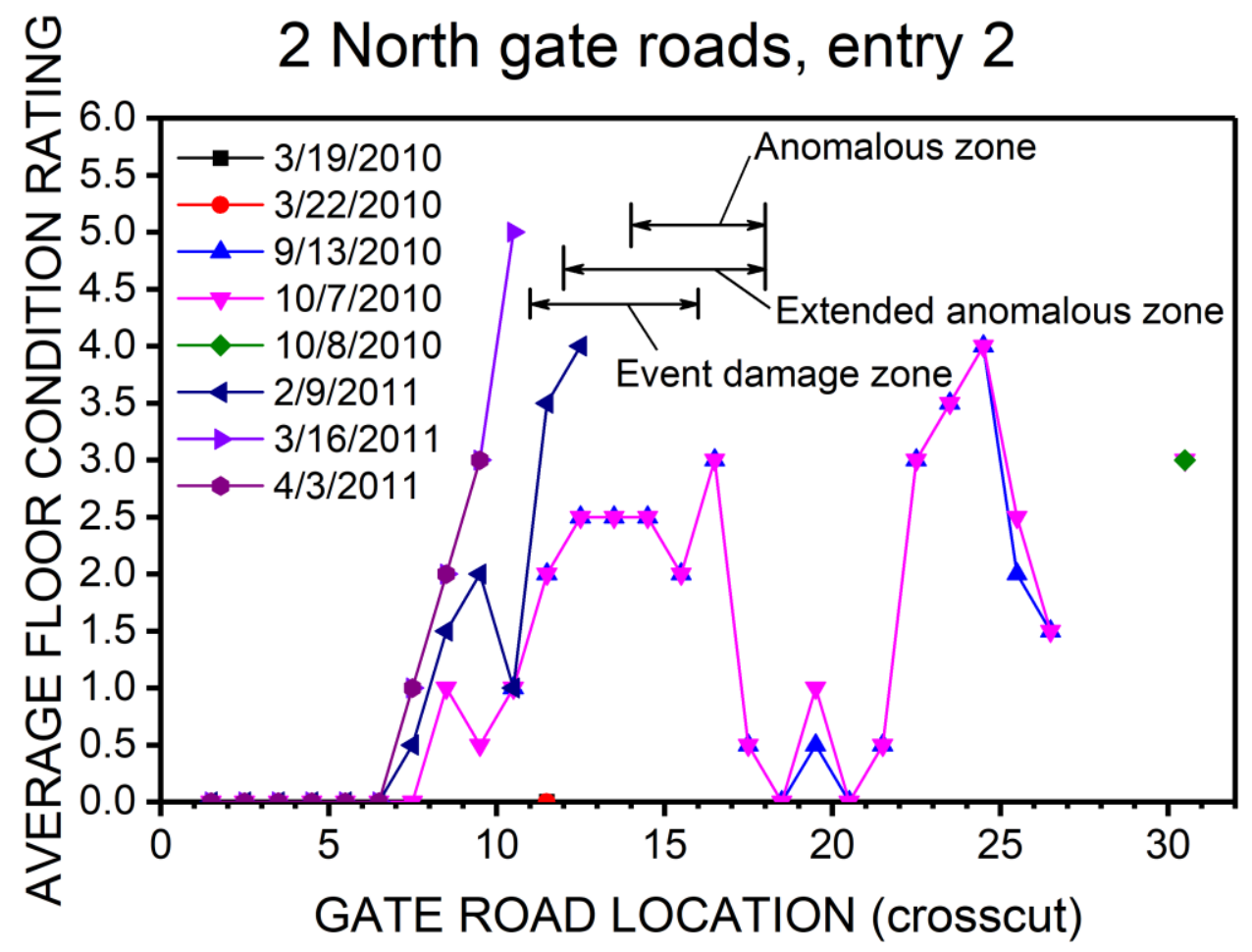

Figure D7. Results of walking survey of average floor condition ratings by location in entry 2 of the 2 North gate roads at Mine $A$.

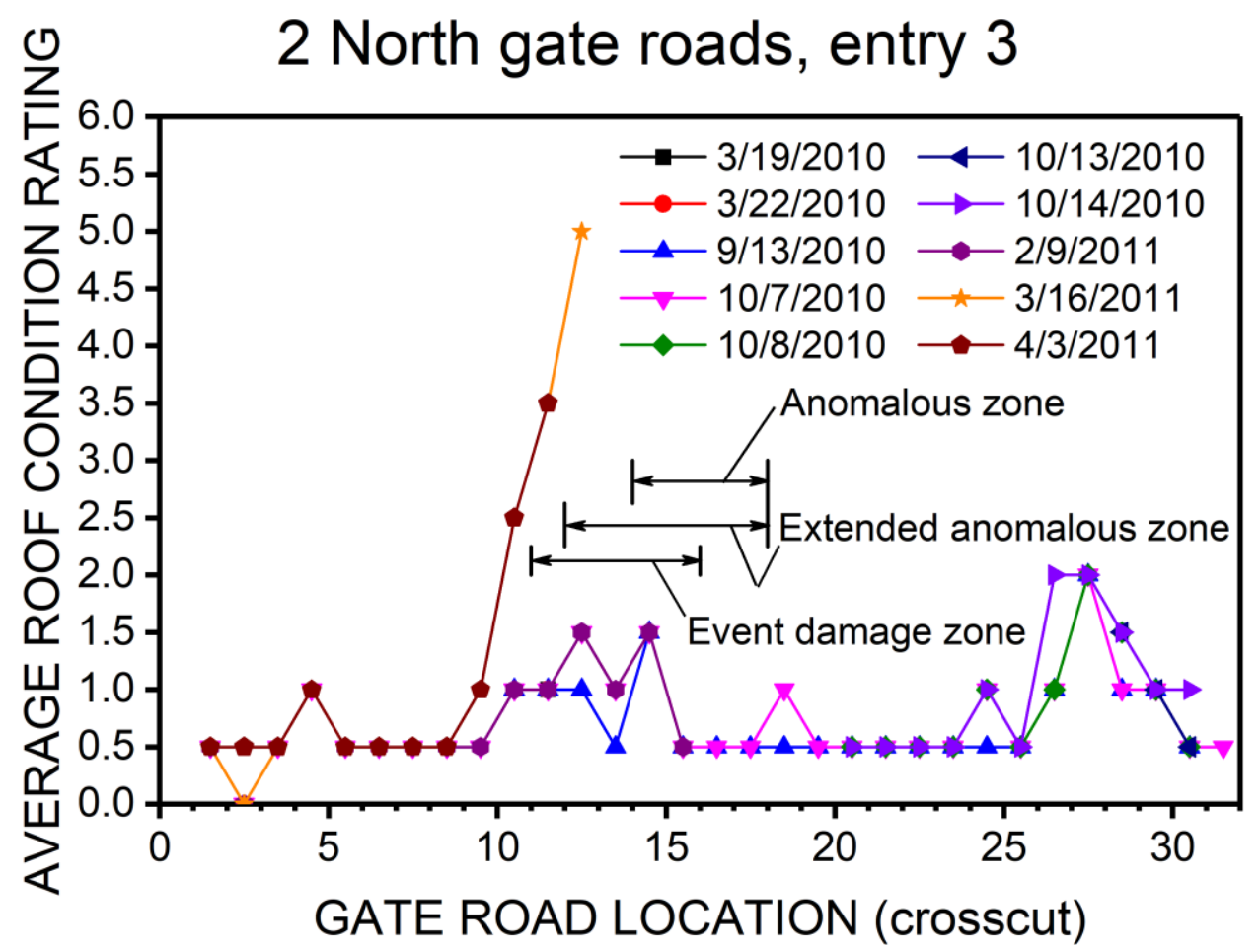

Figure D8. Results of walking survey of average roof condition ratings by location in entry 3 of the 2 North gate roads at Mine A. 


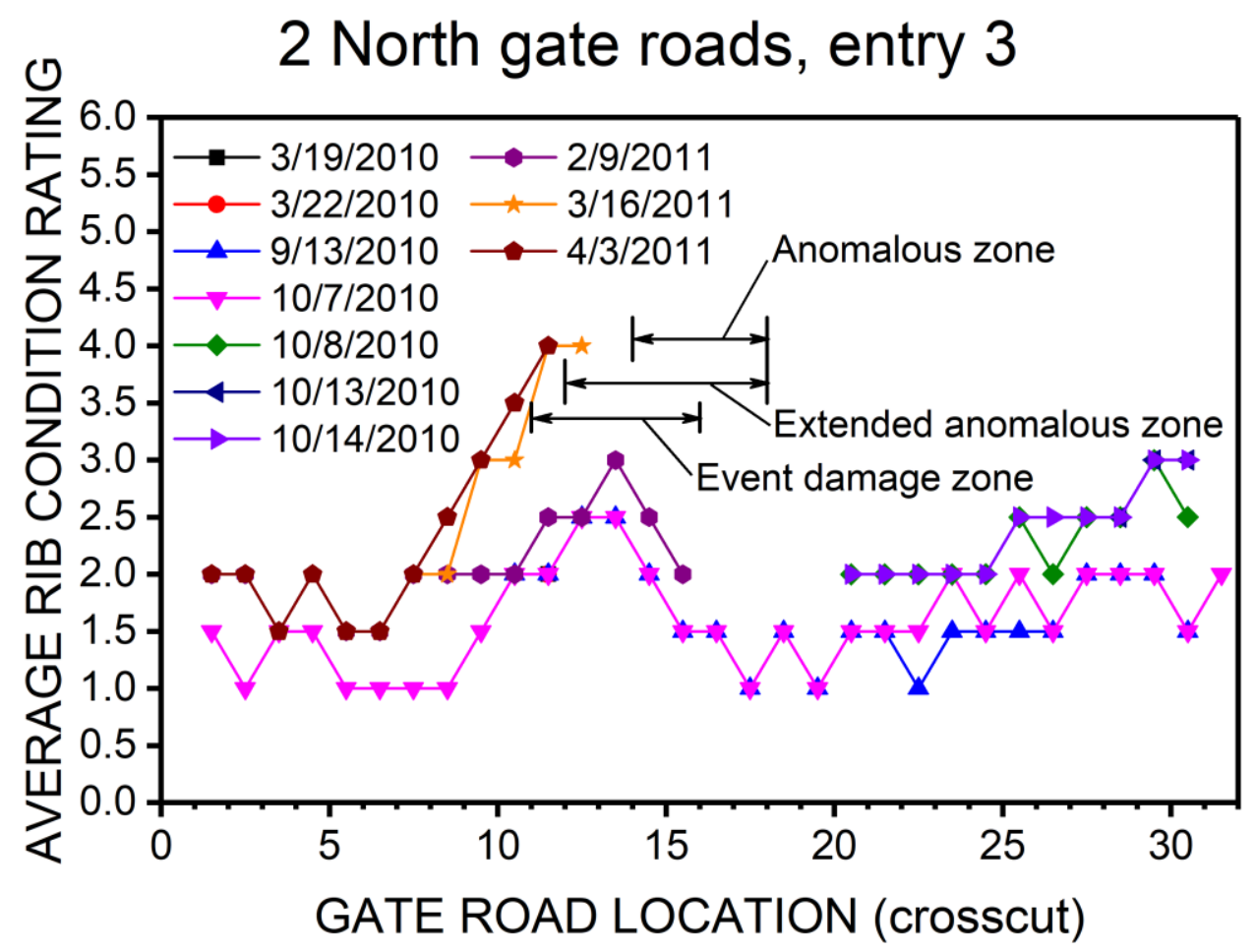

Figure D9. Results of walking survey of average rib condition ratings by location in entry 3 of the 2 North gate roads at Mine $A$.

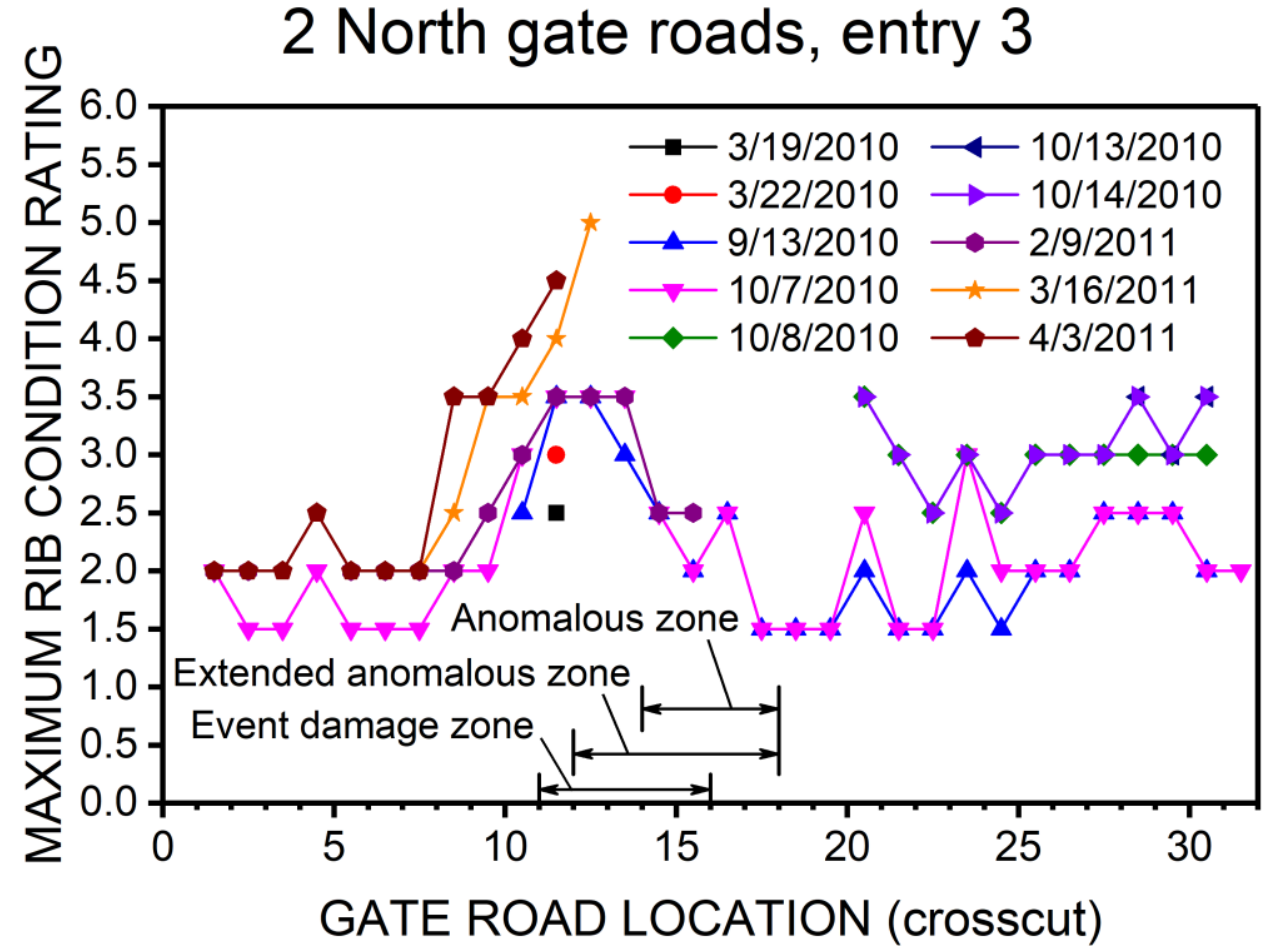

Figure D10. Results of walking survey of maximum rib condition ratings by location in entry 3 of the 2 North gate roads at Mine A. 


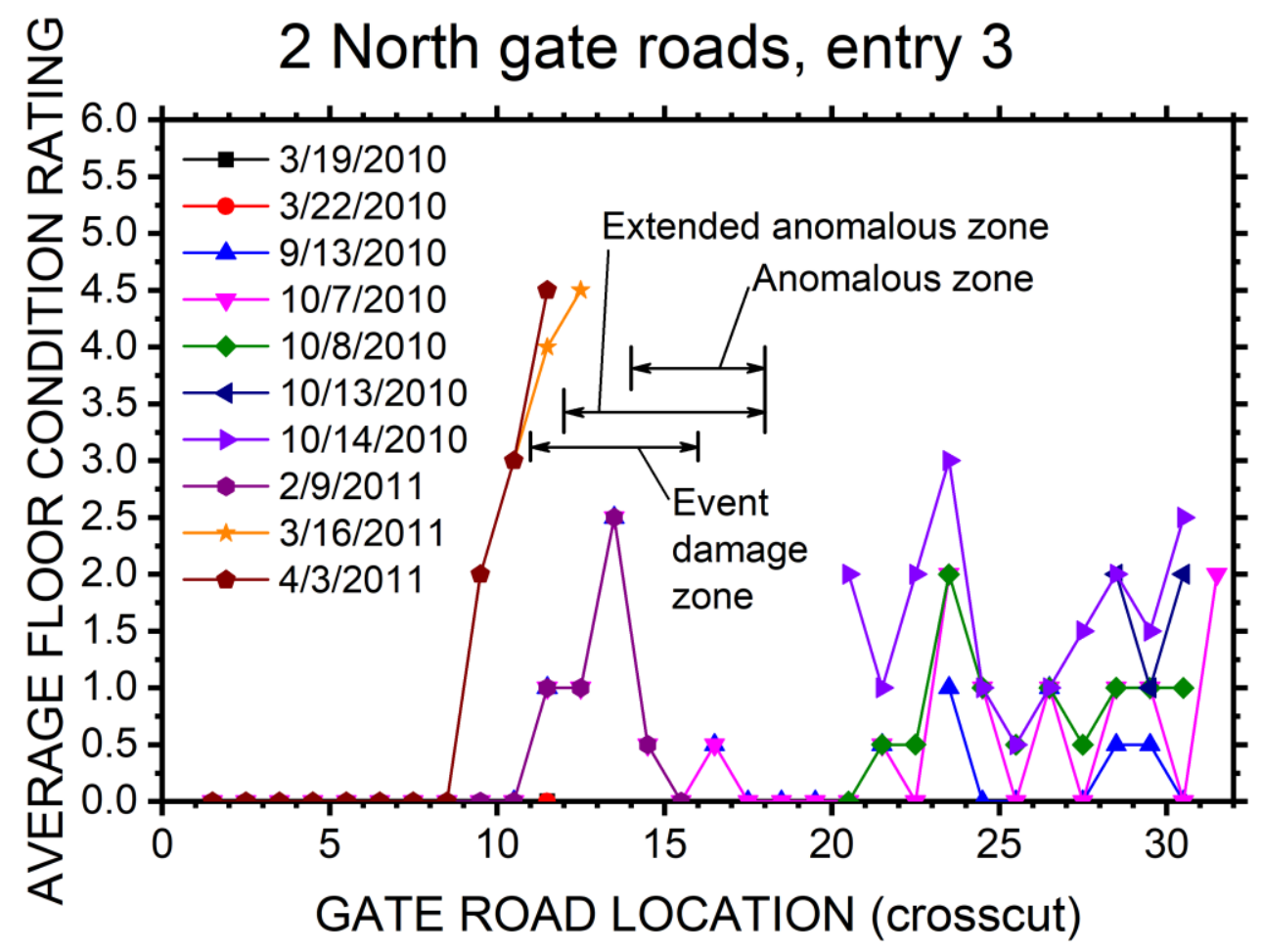

Figure D11. Results of walking survey of average floor condition ratings by location in entry 3 of the 2 North gate roads at Mine $A$. 



\section{Appendix E: Mine B-Borehole Pressure Cell Measurements}

\section{Description}

Borehole pressure cells were installed at the T34, T33, T21, T20, H43, H42, H22, and H21 sites, shown in Figure 5 in the main body of this report. The purpose of this appendix is to report and show the BPC pressure readings at these sites in Mine B. BPC pressures, as demonstrated with measurements from BPCs at Mine A, might be used to help determine first arrival of abutment stresses resulting from panel mining. Unfortunately, the measurements were less than ideal but valuable lessons were learned. This appendix also describes some of the contributing factors to poorer quality data so that the reader might be able to avoid such problems with attention to detail and proper planning.

\section{Experience and Factors Contributing to Decrease in Measurement Quality}

In part, because of prior experience with installing BPCs in which the flatjack was encapsulated in grout before installation by the manufacturer-borehole closure presented difficulties in placing the instruments at target depth - a different style of BPC was chosen for installation at Mine B. In this case, the BPC flatjacks were not encapsulated with grout by the manufacturer but were to be plunged into grout that had just been pumped into the borehole. The plan for installation is illustrated in Figure E1. The borehole was to be drilled at $3^{\circ}$ down from

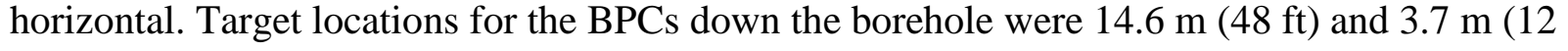
$\mathrm{ft})$. The borehole was to be drilled to a depth of about $15.2 \mathrm{~m} \mathrm{(50} \mathrm{ft)}$ and flushed with water. Grout would be pumped into the borehole to fill up about $3.0 \mathrm{~m} \mathrm{(10} \mathrm{ft)} \mathrm{of} \mathrm{length} \mathrm{before} \mathrm{a} \mathrm{flatjack}$ was plunged into the grout to target depth and oriented so that the flatjack plane was perpendicular to vertical. The authors had no prior experience installing just the flatjack portion of the BPC without prior grout-encapsulation.

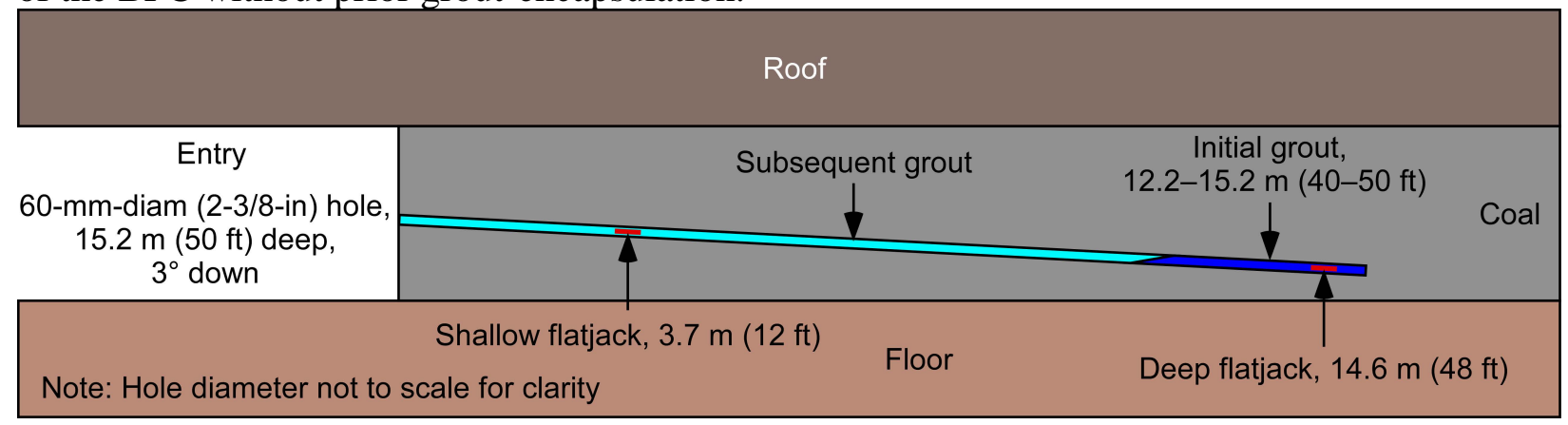

Figure E1. Vertical section of idealized BPC target installation at Mine B.

Another complication that caused deviation from the installation plan was unavailability of water supply in the gate roads. In reality, introducing more water into the gate roads as a result of drilling was undesirable because it was thought to adversely affect stability of the gate roads. This complication limited the choice of drills to a Turmag drill with auger steel. The handheld nature of the drill made it difficult to maintain the desired borehole orientation. Admittedly, the hole meandered to a slightly upward orientation at times. Removal of cuttings to provide a clean 
hole was dependent on turning auger-steel blades, a process that was not thorough and produced a borehole that was, at best, far from ideally clean and smooth.

The full crew was divided into a drilling crew of four and an installation crew of two. The drilling crew drilled boreholes ahead of the installation crew. Thus, the crews were generally not working at the same site concurrently. Water in closed buckets, grout bags, and equipment, necessary to mix and pump the grout, were hauled from the mains on hand-pulled carts having two bicycle wheels.

To reduce risk of poor installation, a flatjack was gently pushed into the borehole with installation rods to discover any obstructions. In the process, rubble from drill cuttings was often encountered, especially at the back end of the hole. Further rubble removal was accomplished with the aid of flatjacks and installation rods, but this method was far from satisfying and very inefficient. In spite of efforts to achieve a clean borehole, it is reasonable to assume that rubble mixed with grout as it encapsulated the flatjack at each instrument site. The grout was mixed to a stiff consistency, but sometimes, a bunched-up and knotted rag was placed in the borehole and pushed with installation rods to move grout deeper in a slightly upward-inclined hole to help encapsulate the flatjack. The rag was tamped to form a dam to help prevent grout from running back toward the collar of the borehole. The same technique was sometimes used for installation of the flatjack at a target depth of $3.7 \mathrm{~m}(12 \mathrm{ft})$. Thus, a borehole may not have been entirely full of grout as idealized in Figure E1.

After installation and initial pressurization of the flatjacks, slight leaks were discovered in the hydraulic system fittings of most instruments. Admittedly, several of these fittings had been used before, but still appeared to be in excellent condition. In many cases, the fittings were tightened and repressurized multiple times. If this effort failed to curtail the leak, then eventually certain fittings were replaced, which seemed to stop visible leakage. However, rubble and small amounts of void space located around flatjacks still would likely contribute to a slow decrease in cell pressure. These phenomena were evident in the measurement trends, shown later in this appendix, even after hydraulic leaks appeared to be stopped.

Another factor that might have contributed to poor data was relative inexperience in the field with the MIDAS datalogger [Sunderman et al. 2003; Jones 2012]. Incorrect wiring is always a possibility with any datalogger, but in this case, the process of downloading data was not foolproof in that it was easy to make an input mistake and write over an existing file. Also, NIOSH personnel were unable to stay on site long enough after installation to see that trends of readings were consistent and in the expected range.

\section{Measurements}

The BPC pressure at T34 (Figure E2) became erratic before first arrival of abutment stress. The cause appears to be some problem in the circuitry which was never resolved. A couple of the trends of BPC pressures at T33 (Figure E3) might have been candidates for determining first arrival of abutment stress, given some degree of steadiness. However, for unknown reasons, no datalogger files for measurements after 1,918 hours were found. It is assumed that these files were inadvertently written over with subsequent use of the datalogger or the files inadvertently deleted.

Figure E4 shows pressures at the T21 site that bled off, but subsequent resetting of the cell pressures after tightening connections or replacing fittings re-established reasonable trends that might be compared with distance to face for possible determination of first arrival of abutment 
stress. The trends of cell pressure at T20, shown in Figure E5, indicate either an instrument that has compromised structural integrity or leakage at a fitting that could not be stopped. The hydraulic leak was too much, and repressurization of the instrument did not establish the cell as viable.

Cell pressures at H43 (Figure E6) and H42 (Figure E7) were installed as part of a parallel study concerning rib behavior and rib failure mechanics. These results could not be used to determine first arrival of abutment stress because the instruments were located too close to the startup room. Instead, one would look for evidence of the timing of first cave over the panel. However, the H43 instrument showed trends of too much leakage that were never resolved, and trends by cells at $\mathrm{H} 42$ were not consistent enough to indicate a first cave, if one occurred.

Figure E8 shows cell pressures at $\mathrm{H} 22$, which were repressurized multiple times after tightening hydraulic connections, and ultimately, replacing fittings. Three of these curves might be candidates for determining first arrival of abutment stress because a consistent decrease in cell pressure after the last repressurization might be characterized before first arrival, and departure from such characterization curves might be a reasonable measure of first arrival. The pressure in the cell in the panel at $14.6 \mathrm{~m}(48 \mathrm{ft})$ is not sufficiently close to the expected vertical stress to have any confidence in that cell responding to mining-induced abutment stress and is, therefore, not a candidate. The trend by the instrument at H21, shown in Figure E9, is not likely a candidate because there is no clear departure from the established trend. Thus, first arrival of abutment stress might be masked by leakage. The chatter that began in these cells may be problematic, but if the cell were a candidate to determine first arrival, using a 9-point rolling average might temper the chatter sufficiently. The cause of the jump at around 4,300 hours is not known.

In summary, of 19 BPCs installed, only seven, four at T21 and three at H22, are possible candidates for determination of first arrival of abutment stress resulting from mining. Four were removed from such candidacy because of proximity to the startup room.

The quality of BPC measurements was compromised by leaking hydraulic connections, nonideal borehole inclinations resulting from the drill method that was available, and probable rubble encapsulated around the instruments mixed with the grout. However, first arrival of abutment stress might still be determined by characterization of a consistent decrease in cell pressure before first arrival of stress resulting from mining and by extrapolating that trend as the face advances so that departure of cell pressure from the initial trend might be clearer. 


\section{T34 station BPC}

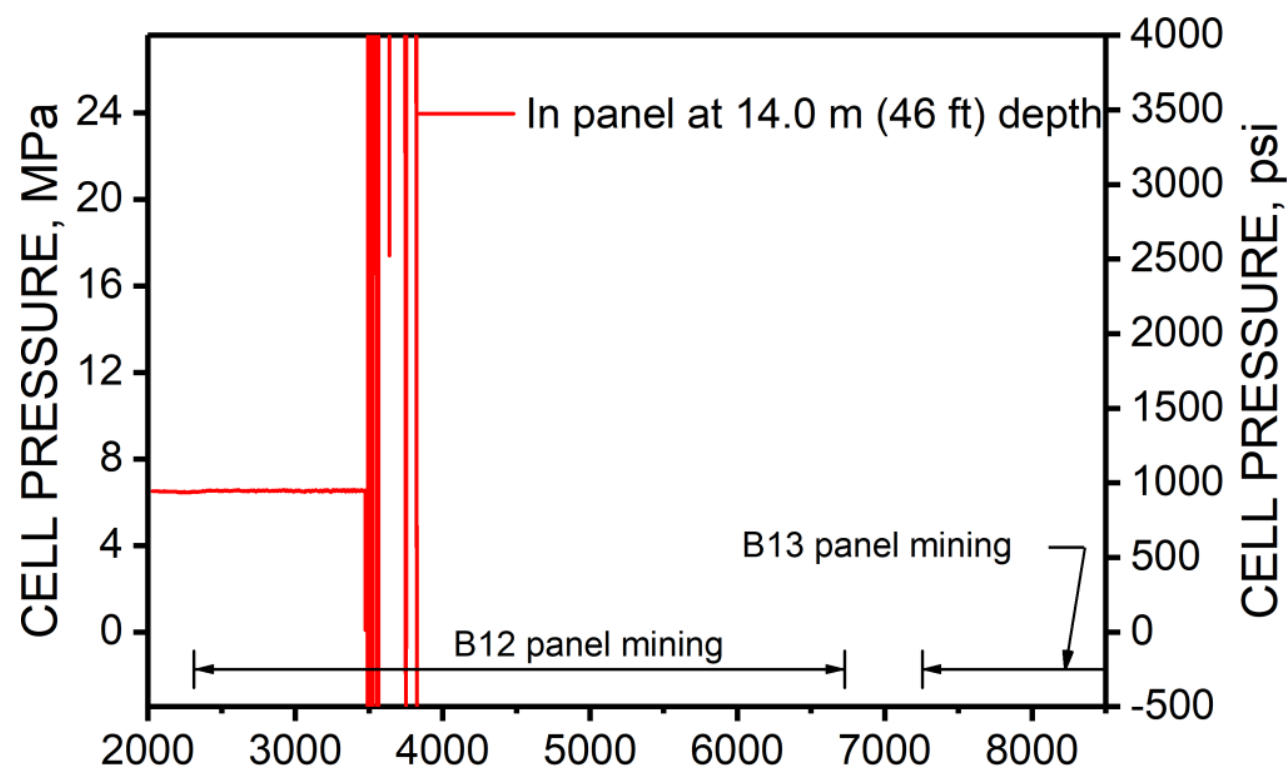

TIME SINCE ZERO TIME, hr

Figure E2. BPC pressure with time at T34 site at Mine B.

T33 station BPCs

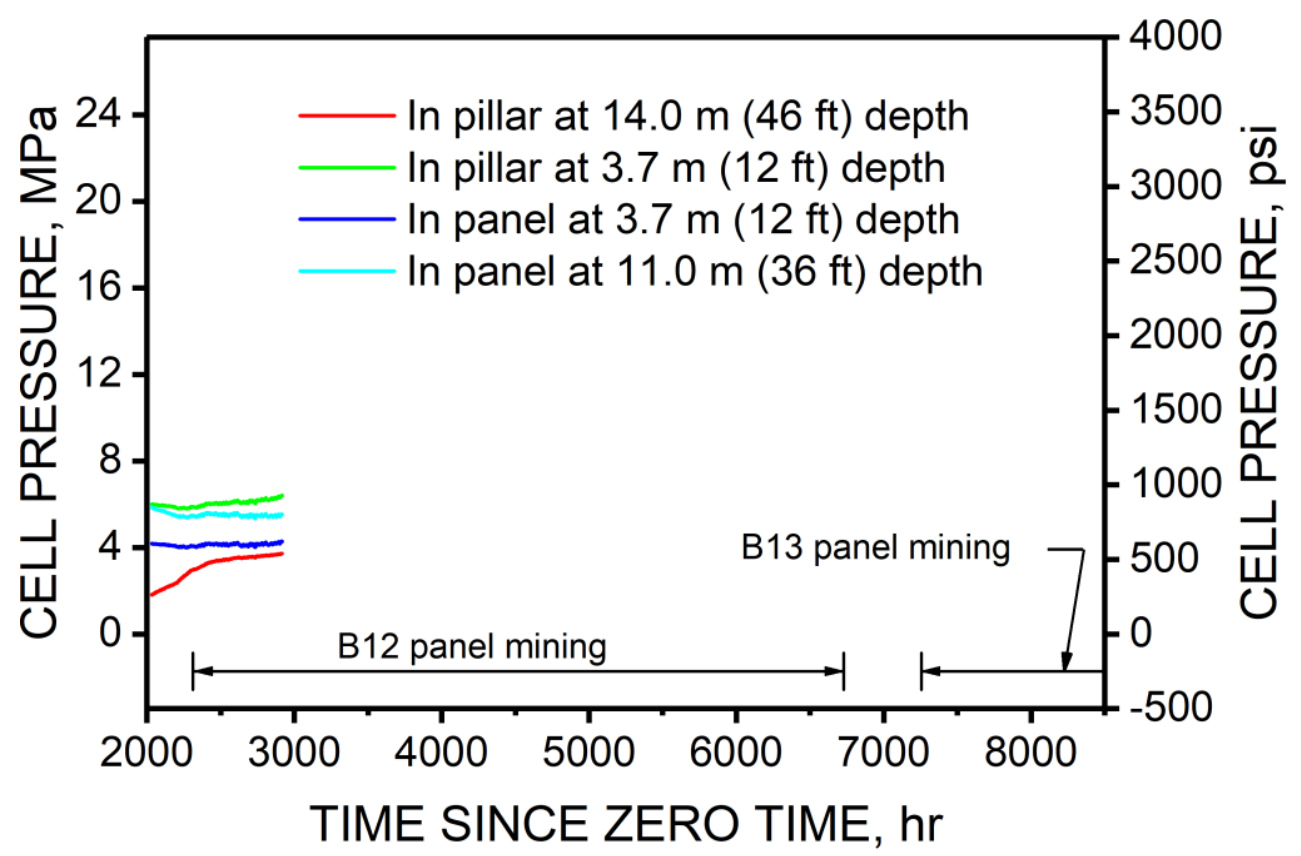

Figure E3. BPC pressures with time at T33 site at Mine B. 


\section{T21 station BPCs}

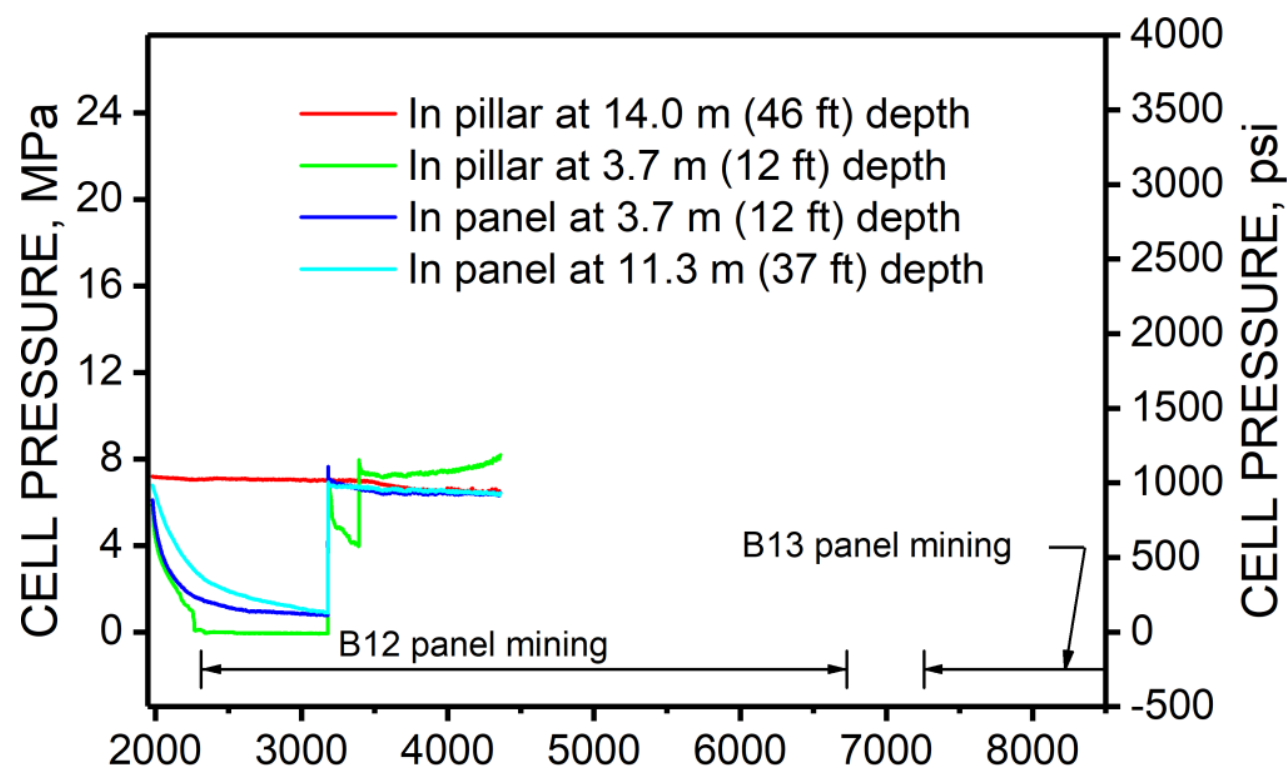

TIME SINCE ZERO TIME, hr

Figure E4. BPC pressures with time at T21 site at Mine B.

T20 station BPC

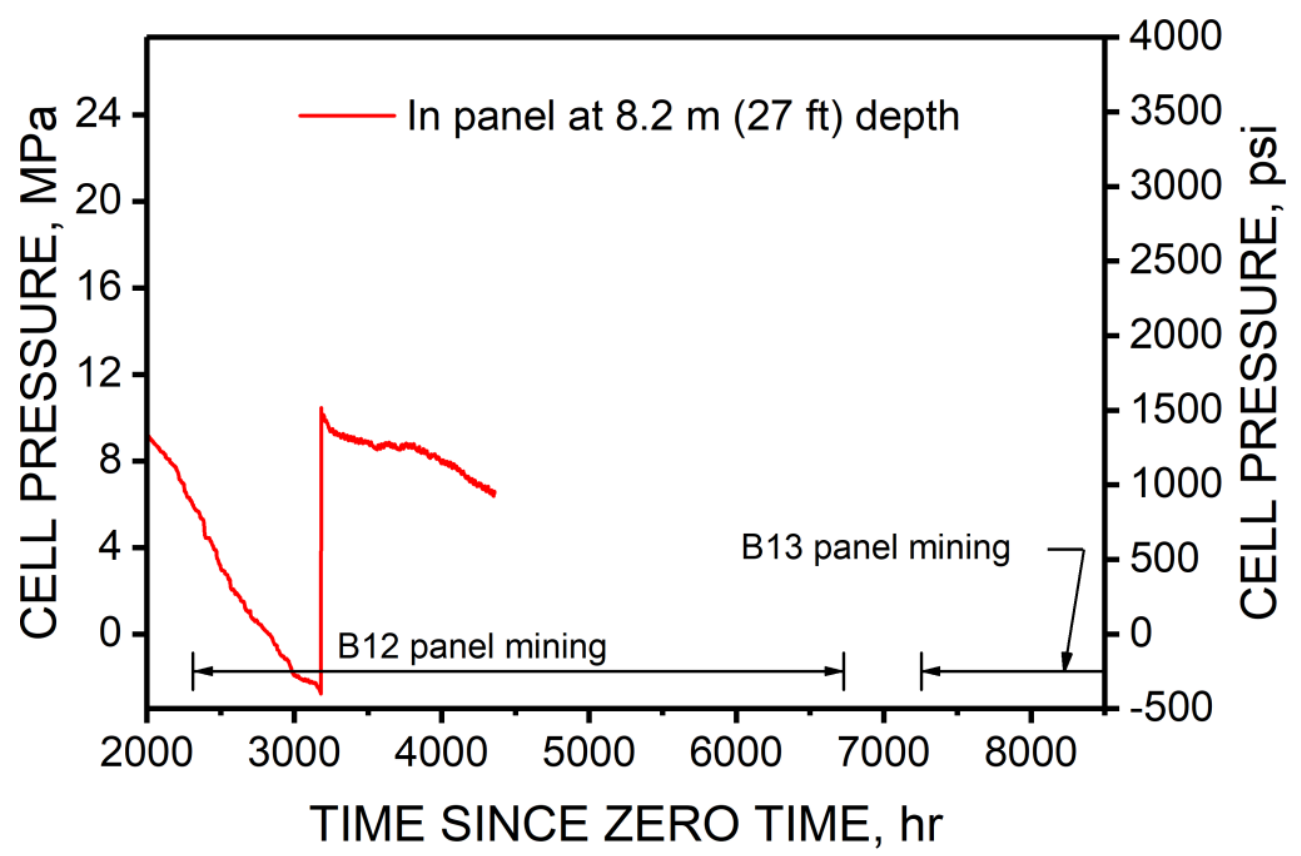

Figure E5. BPC pressure with time at T20 site at Mine B. 


\section{H43 station BPC}

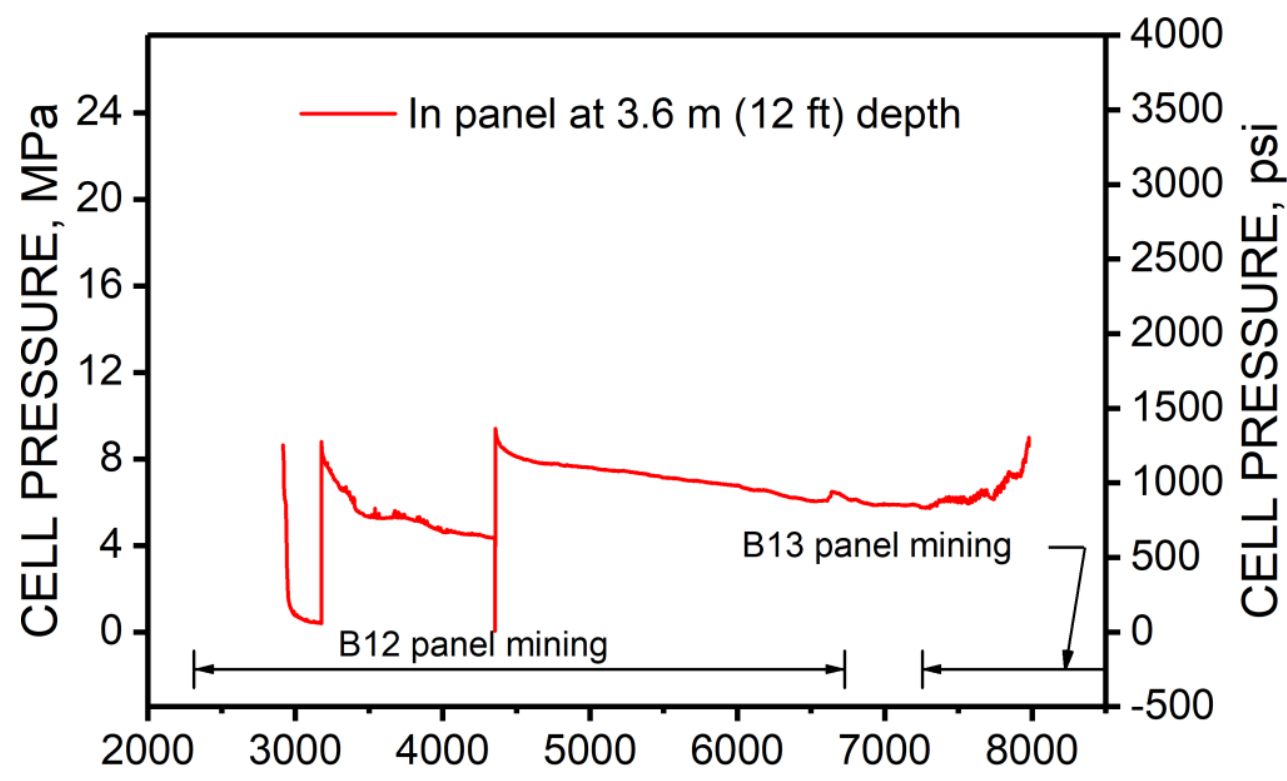

TIME SINCE ZERO TIME, hr

Figure E6. BPC pressure with time at $\mathrm{H} 43$ site at Mine B.

H42 station BPCs

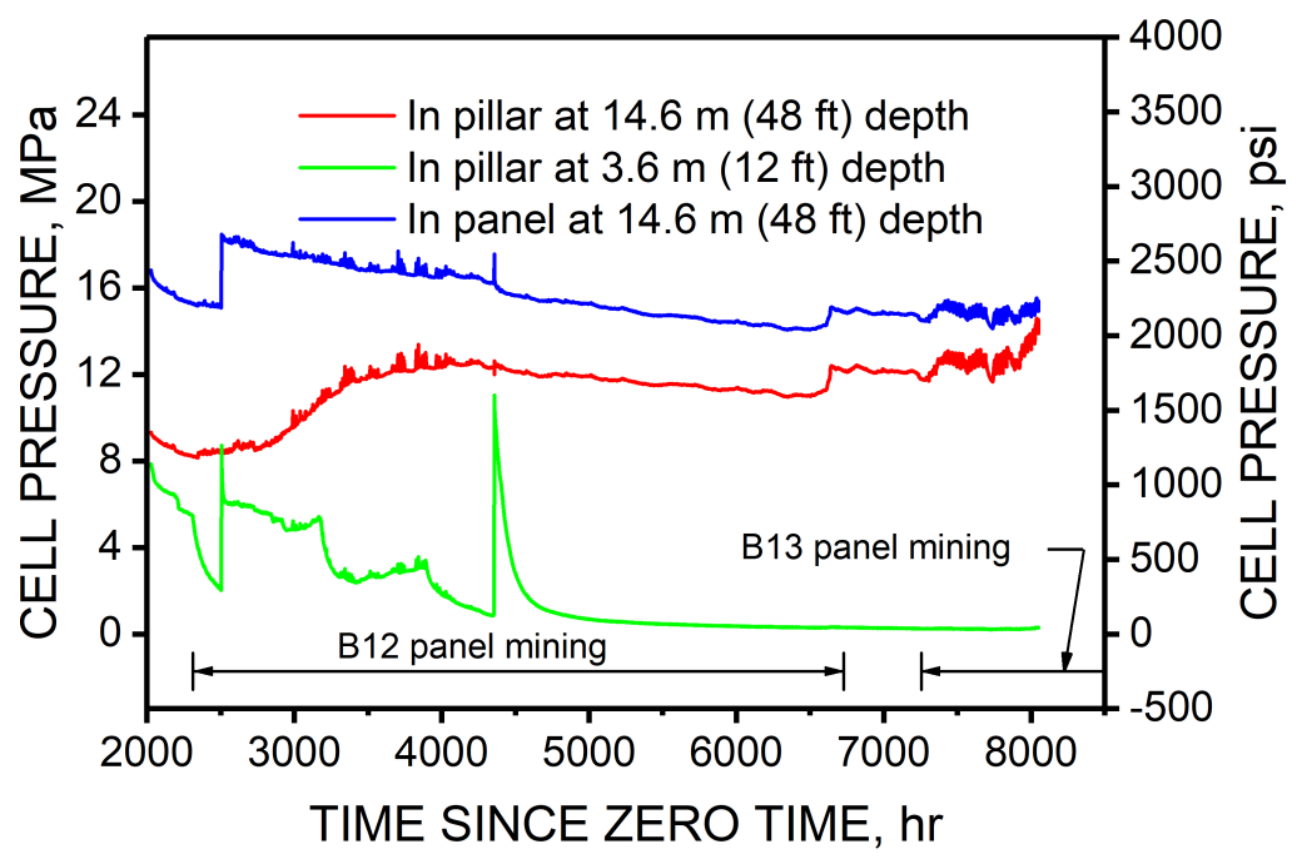

Figure E7. BPC pressures with time at $\mathrm{H} 42$ site at Mine B. 


\section{H22 station BPCs}

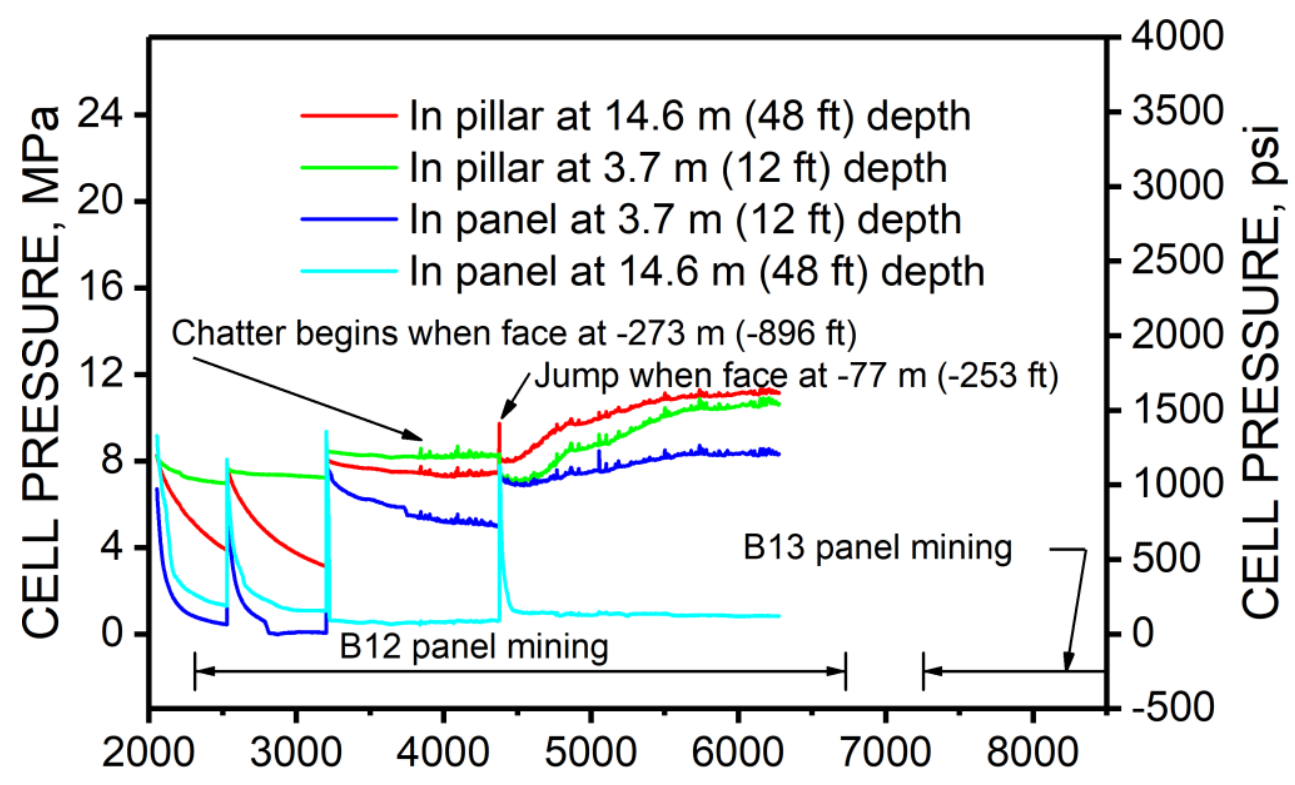

TIME SINCE ZERO TIME, hr

Figure E8. BPC pressures with time at $\mathrm{H} 22$ site at Mine B.

H21 station BPC

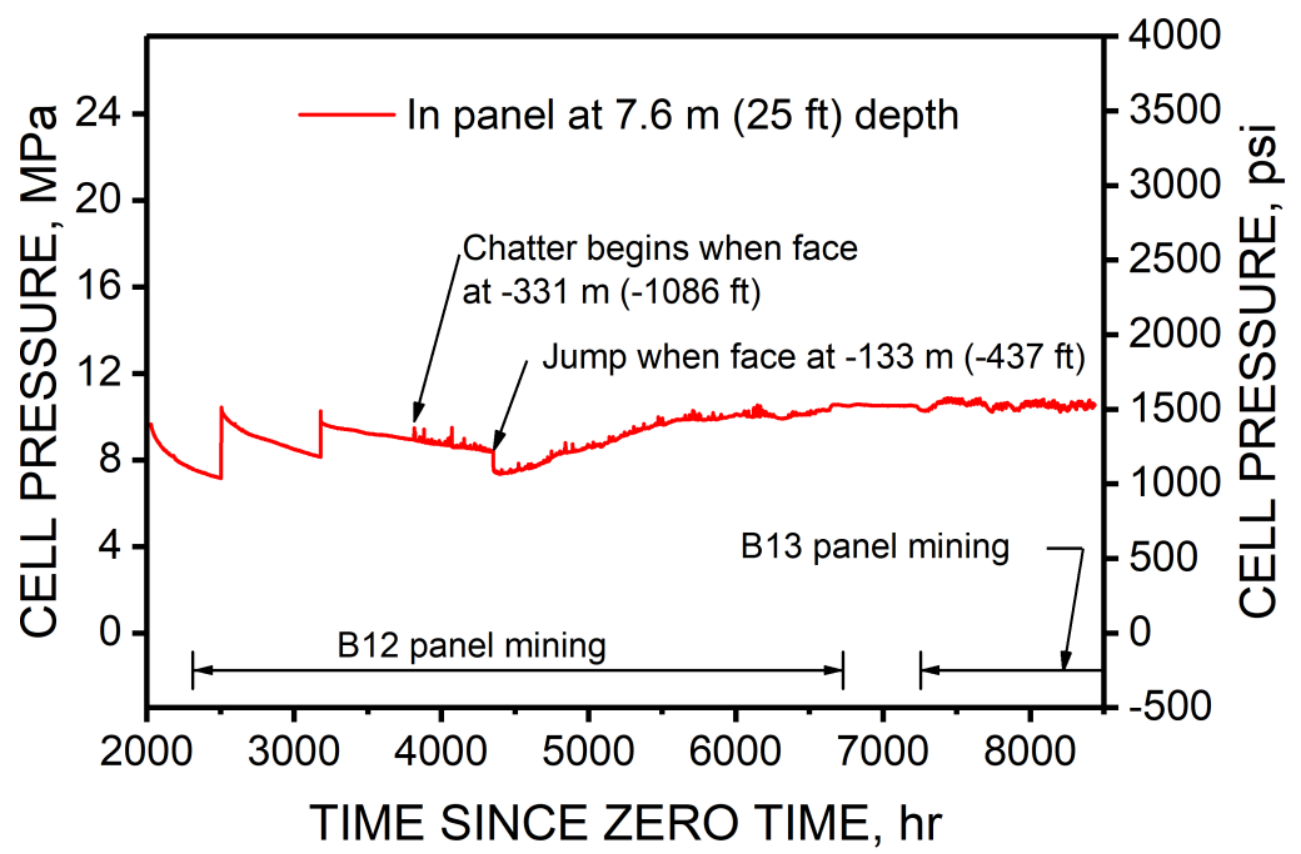

Figure E9. BPC pressure with time at $\mathrm{H} 21$ site at Mine B. 


\section{References for Appendix E}

Jones TH [2012]. Knowledge is power: Introducing the MIDAS, a new permissible datalogging system for use in mines. In: Barczak T et al. eds. Proceedings: 31st International Conference on Ground Control in Mining. (Morgantown, WV: July 31-August 2, 2012) Morgantown, WV: West Virginia University, pp. 245-250.

Sunderman C, Signer S, Johnson J [2003]. A miniature data acquisition system with LED warning lights, in Computer Applications in the Minerals Industries, Proceedings of the Fourth International Conference on Computer Applications in the Minerals Industries (CAMI 2003), ed. by Singhal RK et al. Calgary, AB, p. 7. 


\section{Appendix F: Mine B-Support Can Load Measurements}

\section{Description}

Support Cans of 61-cm (24-in) diameter were regularly installed along the centerline of entry 3 of each gate road at approximately 3.4-m (11-ft) intervals. Eight of these Cans were installed with hydraulic bladders, plywood, and cribs on top in the B-12 headgate/B-13 tailgate, with two each at instrument stations H43, H42, H22, and H21. Pressure transducers of 1,000-psi measuring-range capacity were attached to the bladders. These bladders had been previously calibrated at the NIOSH laboratory in Bruceton, PA, but no identifying information was recorded. However, slopes of the calibrations were consistently close. The difference between the maximum and minimum slopes was $2.28 \%$ of the average slope. Therefore, it was determined to use the average slope to convert the measurements to loads on the Cans. Sensitivity of the loads by the datalogger was $78.45 \mathrm{~N}(17.64 \mathrm{lb})$, which is greater than the sensitivity available with the datalogger at Mine A (about $27 \mathrm{~N}$ or $6 \mathrm{lb}$ ).

Figure F1 shows support Can loads with time from three of the four sites. The data and any notes from the $\mathrm{H} 22$ installations are missing for unknown reasons. Measurements from the $\mathrm{H} 43$ and $\mathrm{H} 42$ sites were installed well after mining of the B-12 panel was underway. However, the loads on Cans at the $\mathrm{H} 21$ would potentially be candidates for determination of first arrival of abutment stress during mining of the B-12 panel. Load on the inby Can did not increase much, possibly indicative of a hydraulic leak or a loading column that was very soft for some unknown reason, and therefore, it is not expected to be sensitive to first arrival of abutment stress. The outby Can curve was very noisy, but the overall trend was reasonable during mining of the B-12 panel, even though it lost load after mining of that panel was completed-probably resulting from a bladder that failed. Therefore, the outby Can curve at $\mathrm{H} 21$ is the only candidate for determining first arrival of abutment stress resulting from mining. 


\section{H43, H42, H21 station support Can loads}

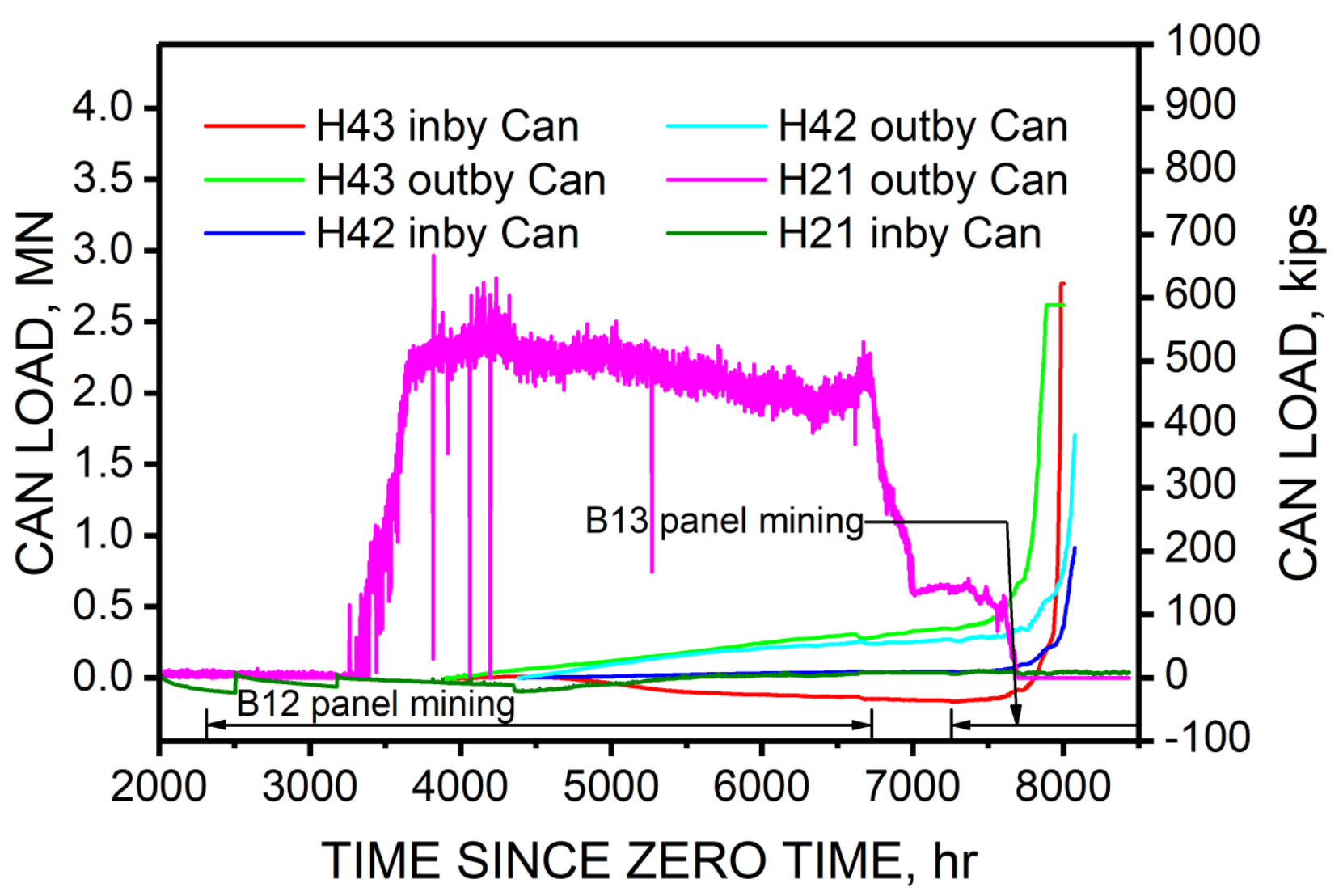

Figure F1. Loads on support Cans at Mine B sites. 


\section{Appendix G: Mine B-Entry Closure Measurements}

\section{Description}

Considering the experience at Mine A in showing the possibility of using entry closures and Can closures to indicate first arrival of abutment stress, an instrumentation plan was developed and executed at Mine B to experiment with this method in several locations along gate roads. This plan was executed in two phases. The purpose of the first phase was to determine what measurements would be most meaningful, and the purpose of the second phase was to carry out the most meaningful measurements in several places along a gate road. If such measurements were successful, it would be useful to see how distance to first arrival of abutment stress might vary as a panel is mined.

The Phase 1 plan was implemented at sites T5 and T6 in the B-11 panel tailgate and at T15 and T16 sites in the B-11 panel headgate (see Figure 5). The target instrumentation plan during Phase 1 is shown in Figure G1. The objective was to measure several items to evaluate as likely candidates for use in the Phase 2 plan, including entry closure, closure of the Can itself, closure of the upper end of the Can and the cribbing, and closure from the roof to approximately the mid-height of the Can. These stations were installed with the B-11 panel face not far away. Therefore, determination of first arrival of abutment stress was not a consideration.

Figure G2 shows the response of closure measurements at T6. Figure G3 shows the response of closure measurements at T5. The \#3 measurement from crib to Can mid-height was not possible at T5 because of lack of cribbing. Data at both of these sites were cut short for some unknown reason-possibly a problem in retrieving data from the MIDAS dataloggers. In any event, no clear trends of mining-induced closure are indicated. Distance to the face from the instrument site (where a negative sign indicates the face is inby the site) were from $-229 \mathrm{~m}$ to -

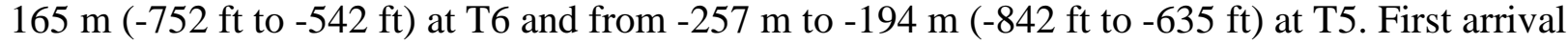
of abutment stress should have already taken place or shown evidence during this period, but measurements at neither site show clear evidence of even expected increasing abutment stress. Continued closure because of mining-induced stress increase is not evident.

Figures G4 and G5 show the response of closure measurements at T16 and T15, respectively. At both of these sites, rubble at the immediate roof and $41 \mathrm{~cm}$ (16 in) thickness of rubble on the floor caused measurement of entry closure to be impractical. In addition, wedges without cribbing at T16 made installation of a string potentiometer on wood impractical so that closure \#3 shown in Figure G1 was not made. Of the measurements shown, the closure from roof to midheight on the Can showed the most response.

Experience at Mine A suggested that the measurement of entry closure would be more likely to be successful than entry closure at the Can. Consequently, the target closure measurements for Phase 2 sites were chosen to be two entry closures and two closures of roof to mid-Can height, as shown in Figure G6. Figure G6 also shows the configuration of Can bladders or flatjacks for measurement load on Cans and target locations of rib and roof extensometers and BPCs. 


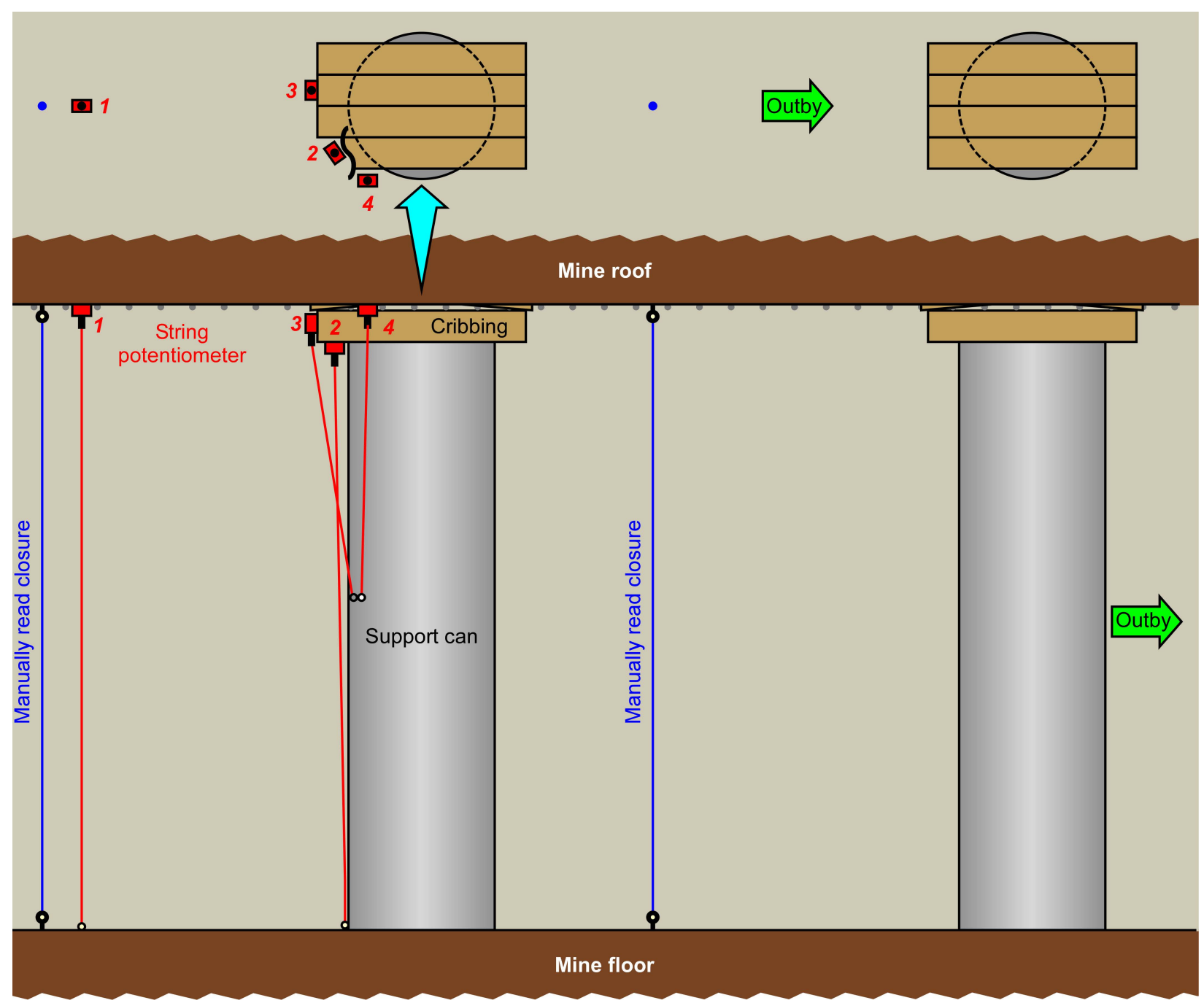

Figure G1. Target closure measurements with string potentiometers, shown along centerline of entry, in phase 1 of the field study at Mine B, for (1) entry closure, (2) Can closure, (3) closure from top crib to mid-height of Can, and (4) closure from roof to mid-height of Can. 


\section{T6 instrument site}

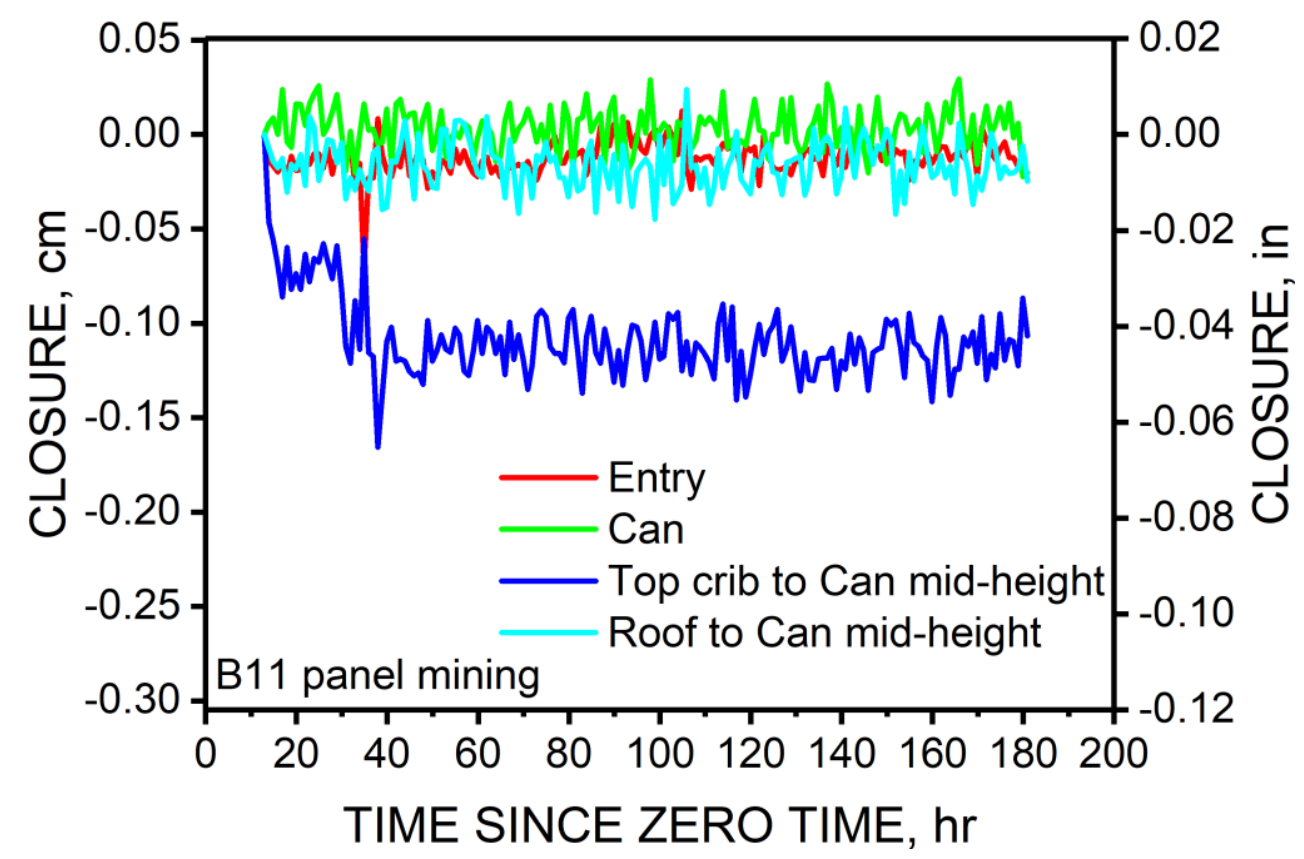

Figure G2. Closure with time as measured with string potentiometers at and near support Can at Phase 1 site of T6 in B-11 panel tailgate at Mine B.

\section{T5 instrument site}

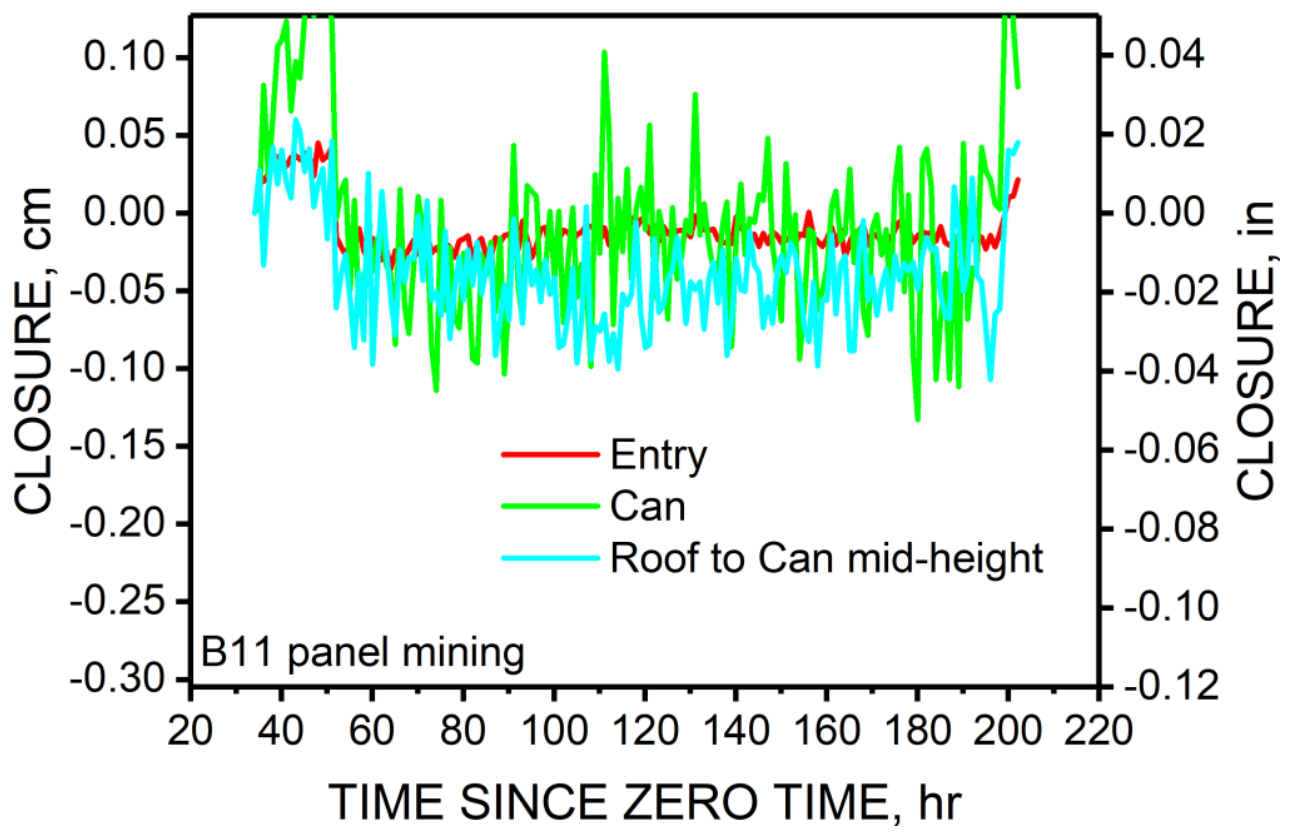

Figure G3. Closure with time as measured with string potentiometers at and near support Can at Phase 1 site of T5 in B-11 panel tailgate at Mine B. 


\section{T16 instrument site}

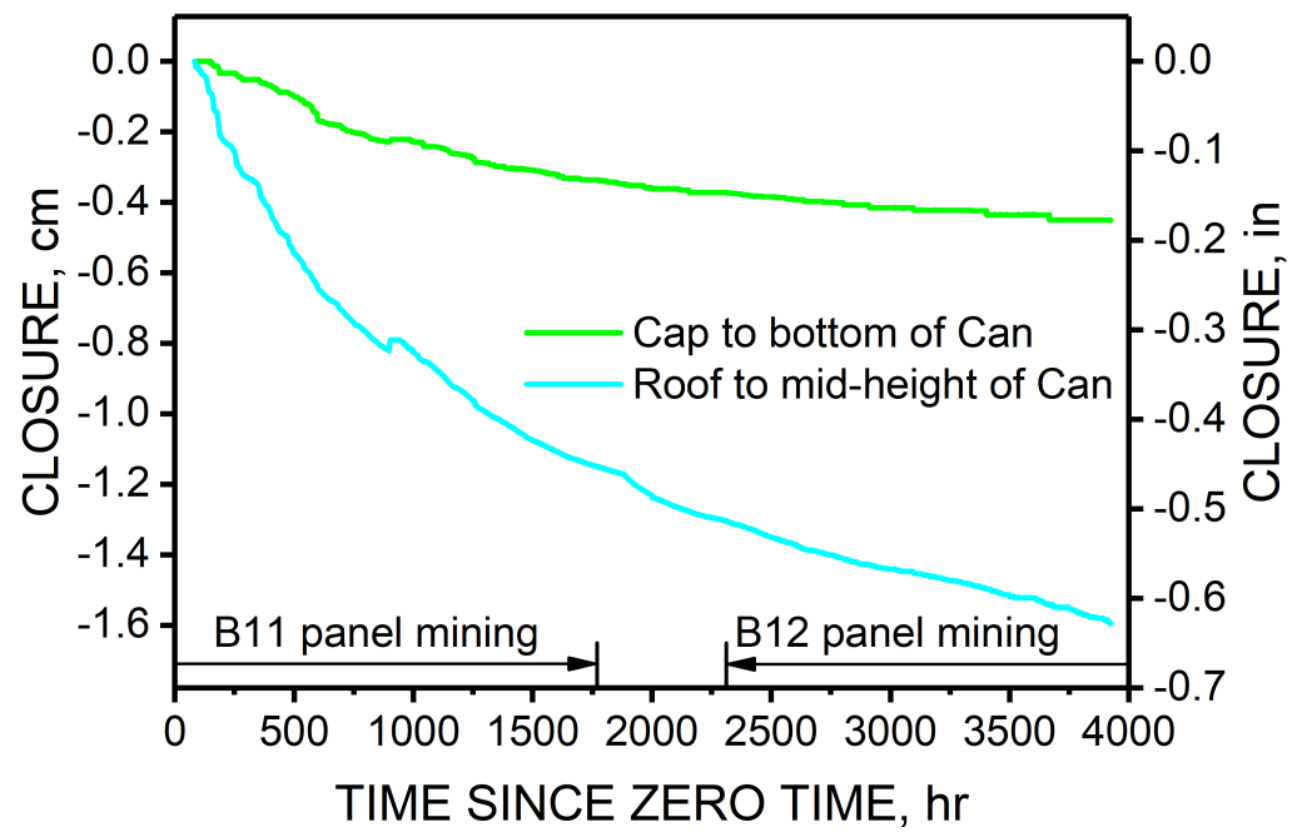

Figure G4. Closure with time as measured with string potentiometers at and near support Can at Phase 1 site of T16 in B-11 panel headgate at Mine B.

\section{T15 instrument site}

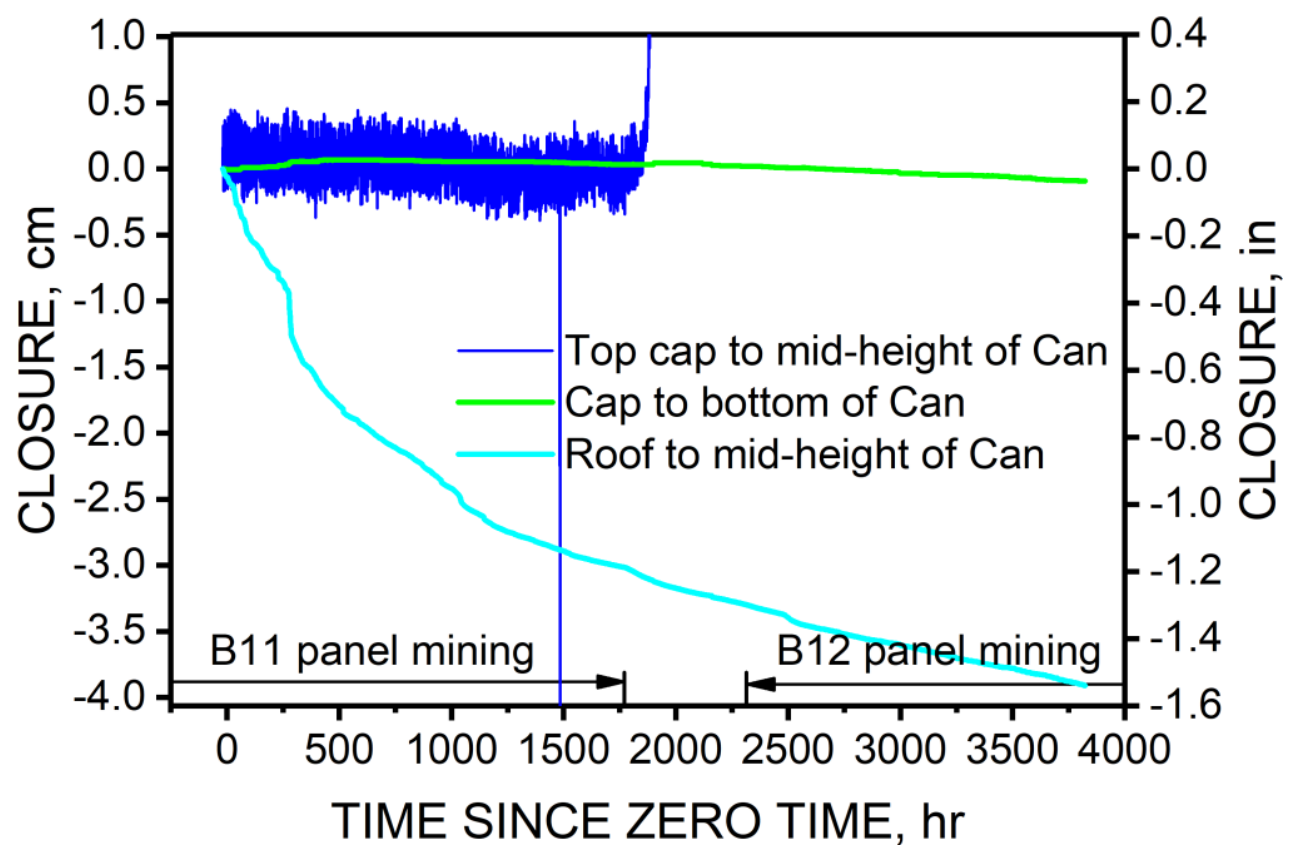

Figure G5. Closure with time as measured with string potentiometers at and near support Can at Phase 1 site of T15 in B-11 panel headgate at Mine B. 


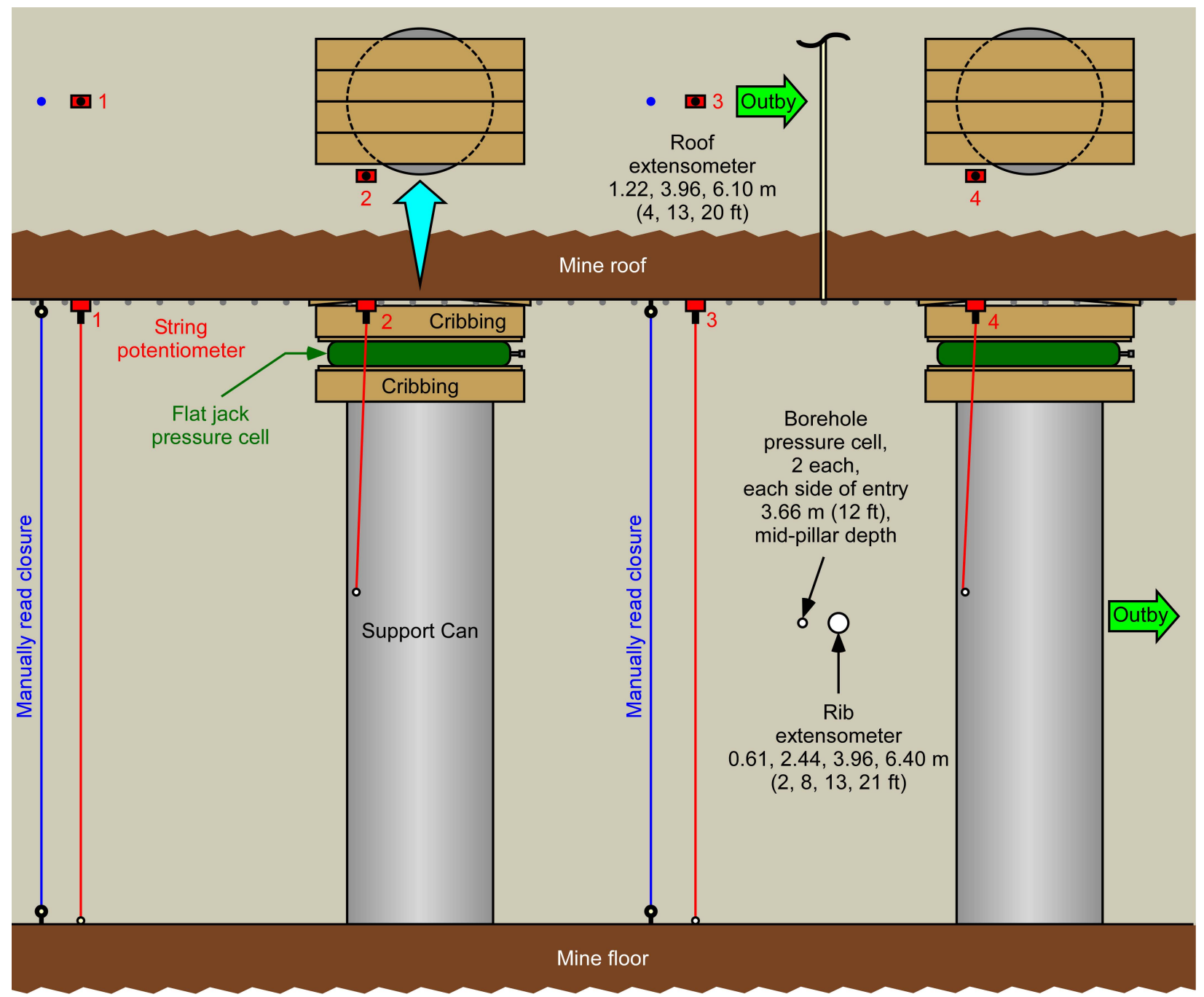

Figure G6. Target closure measurements with string potentiometers, shown along centerline of entry, in phase 2 of the field study at Mine B, for (1) entry closure, inby set; (2) Can closure from near roof to mid-height of Can, inby set; (3) entry closure, outby set; and (4) Can closure from near roof to mid-height of Can, outby set. Roof and rib extensometers were installed only at $\mathrm{H} 42$ site. Can bladders were installed only in the B-12 headgate. String potentiometer closures were not installed in the B-12 headgate, but this configuration was used only at Phase 2 sites in the B-12 tailgate.

String potentiometer closures were only installed in the B-12 panel tailgate. The order of instruments varied from site to site, but in the figures to follow, measurements 1 and 2 were the outby closures, and measurements 3 and 4 were the inby closures, as opposed to the target configuration shown in Figure G6. Figure G7 shows closures at T39. This site was too close to the startup room to give clear indication of first arrival of abutment stress. However, two of the potentiometer measurements show closure resulting from mining. The inby Can closure was too noisy, inconsistent, and with the wrong trends to be believable.

Figure G8 shows closure at T34. The outby closures show consistent early trends of closure, followed by an increase in the rate of closure when abutment stress began to have effect.

Therefore, these two outby closures are candidates for determination of distance from the face at which abutment stress first arrived. 


\section{T39 instrument site}

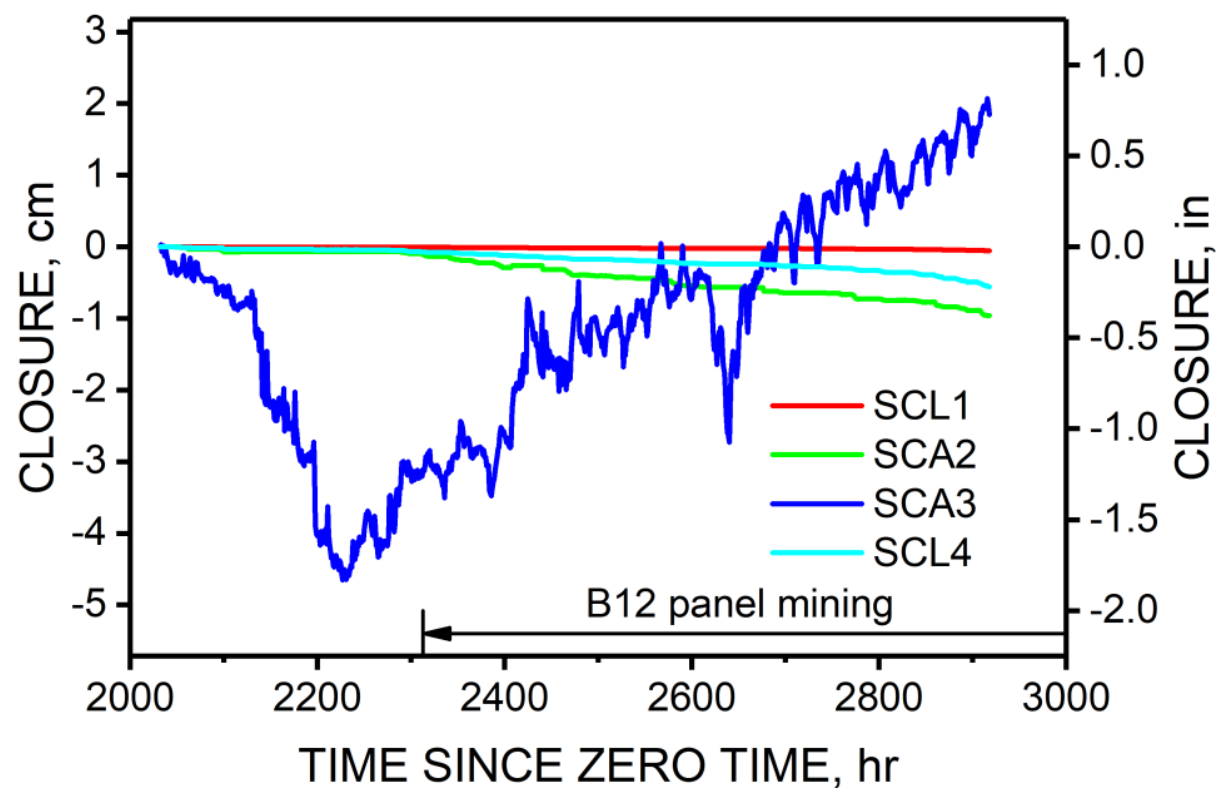

Figure G7. Closure with time as measured with string potentiometers at and near support Can at T39 in B-12 panel tailgate at Mine B. SCL1 = outby entry closure, SCA2 = outby Can closure, SCA3 = inby Can closure, SCL4 = inby entry closure.

\section{T34 instrument site}

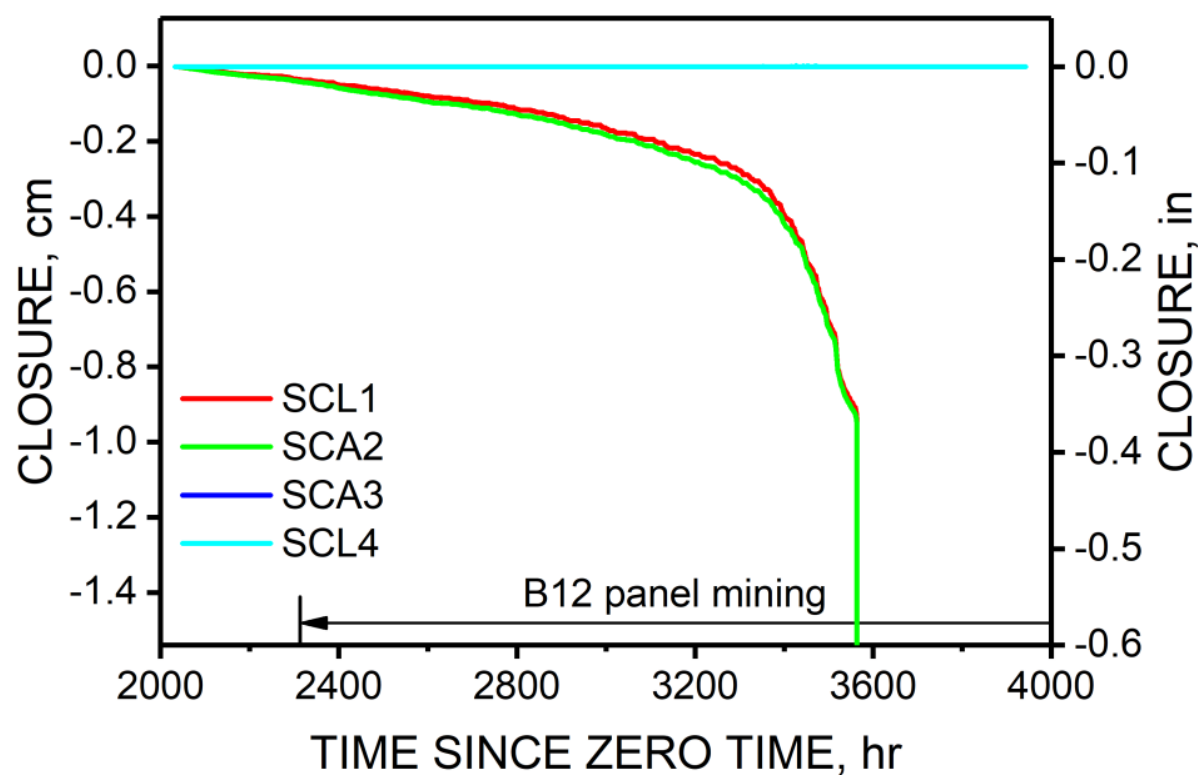

Figure G8. Closure with time as measured with string potentiometers at and near support Can at T34 in B-12 panel tailgate at Mine B. SCL1 = outby entry closure, SCA2 = outby Can closure, SCA3 = inby Can closure, SCL4 = inby entry closure. 
The closures measured at T33, in Figure G9, are not all shown. Measurements taken after 2,917.5 hrs were lost for unknown reasons. Likely, MIDAS datalogger files were accidentally overwritten. Unfortunately, the data lost includes the portion of the curves when arrival of abutment stress might have been first indicated.

Closures measured at T21, in Figure G10, even if noisy, show some unexpected initial trends. Those trends start to show some degree of consistency, but something happened that either took the string pots suddenly to the end of their ranges (but some would have had to be wired in reverse) or compromised the circuitry inside of the MIDAS datalogger. Unfortunately, first arrival of abutment stress would be expected somewhere between 3,600 and 4,000 hrs. Therefore, none of these measurements are candidates for determining the distance to the face from the measurement site at which the abutment stress was first detected.

At T20, shown in Figure G11, the outby closure measurements are not useful, but the inby measurements show an increasing rate of closure during the expected time of arrival. Therefore, the inby closures are candidates for determining distance from the measurement site to the face at which arrival of mining-induced abutment stress is first detected.

Figure G12 shows manual measurements by crosscut location. The purpose of these measurements is verification of the string potentiometer closures. That comparison was made against those closures measured by string potentiometers that are candidates to determine distance to the face from the measurement site at which mining-induced abutment stress was first detected. Figure G13 shows that comparison. The manual measurements showed change in the wrong direction. A number of factors could have affected the manual measurements, including cleanup of the floor and accidental jarring of the floor anchors by personnel and equipment. It can be concluded that manual measurements were not a good way to verify entry closure measurements conducted with string potentiometers. 


\section{T33 instrument site}

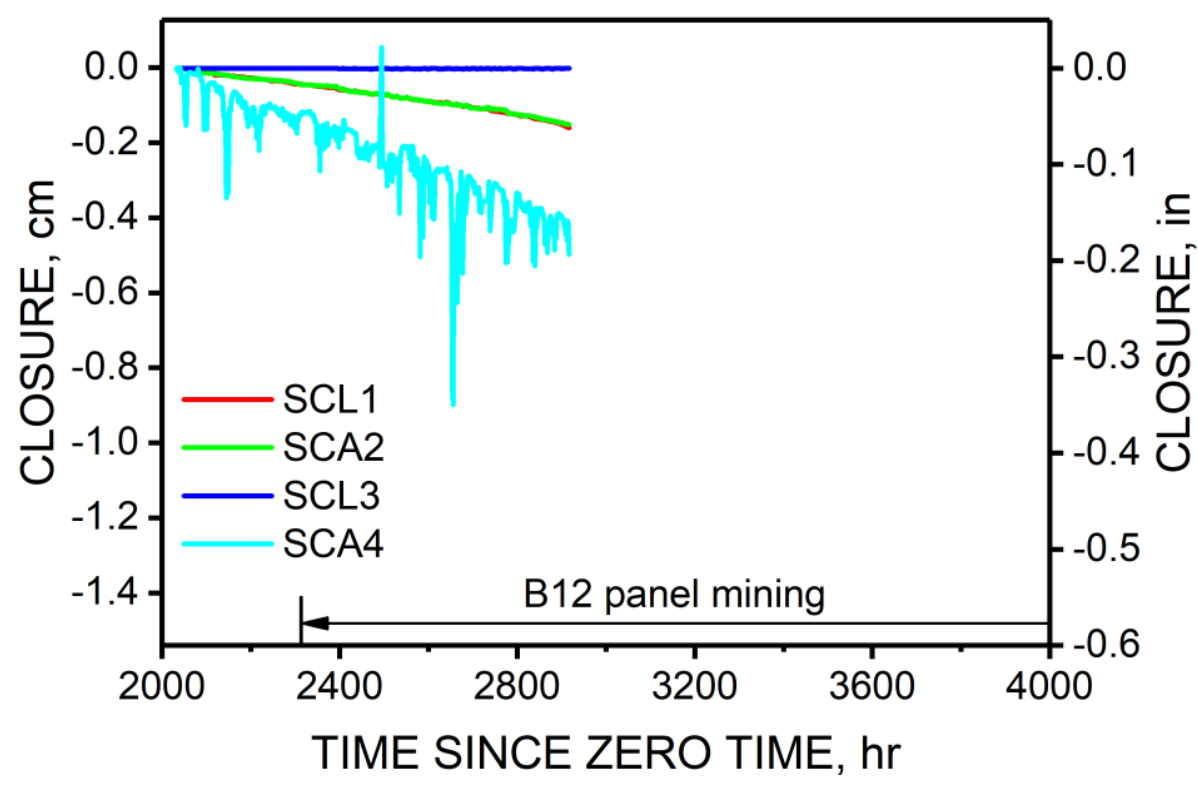

Figure G9. Closure with time as measured with string potentiometers at and near support Can at T33 in B-12 panel tailgate at Mine B. SCL1 = outby entry closure,

SCA2 = outby Can closure, SCL3 = inby entry closure, SCA4 = inby Can closure.

\section{T21 instrument site}

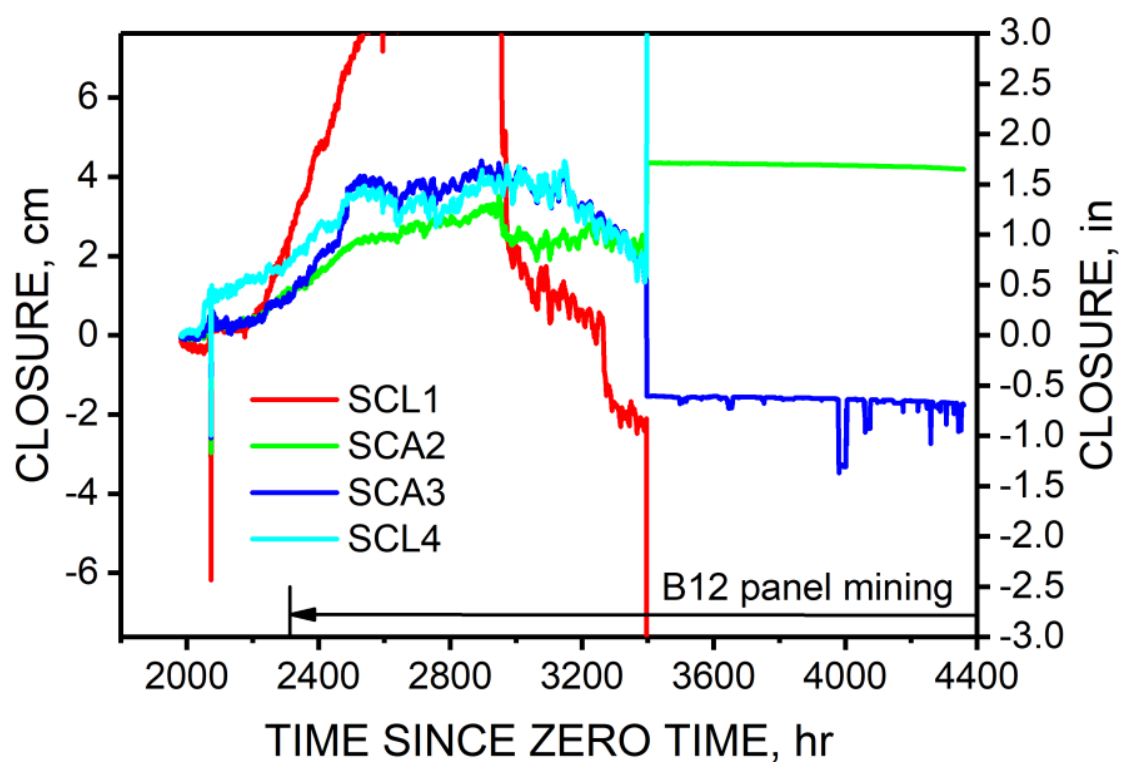

Figure G10. Closure with time as measured with string potentiometers at and near support Can at T21 in B-12 panel tailgate at Mine B. SCL1 = outby entry closure, SCA2 = outby Can closure, SCA3 = inby Can closure, SCL4 = inby entry closure. 


\section{T20 instrument site}

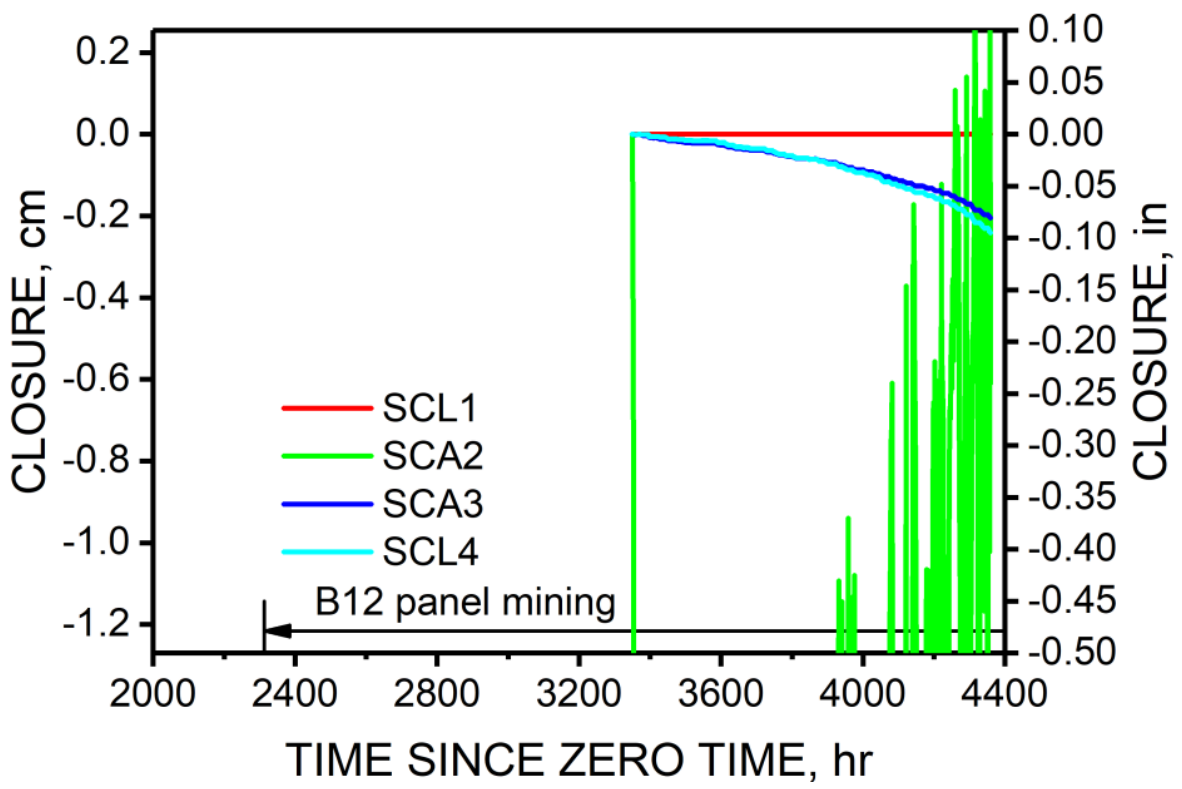

Figure G11. Closure with time as measured with string potentiometers at and near support Can at T20 in B-12 panel tailgate at Mine B. SCL1 = outby entry closure, SCA2 = outby Can closure, SCA3 = inby Can closure, SCL4 = inby entry closure.

Manually measured entry height

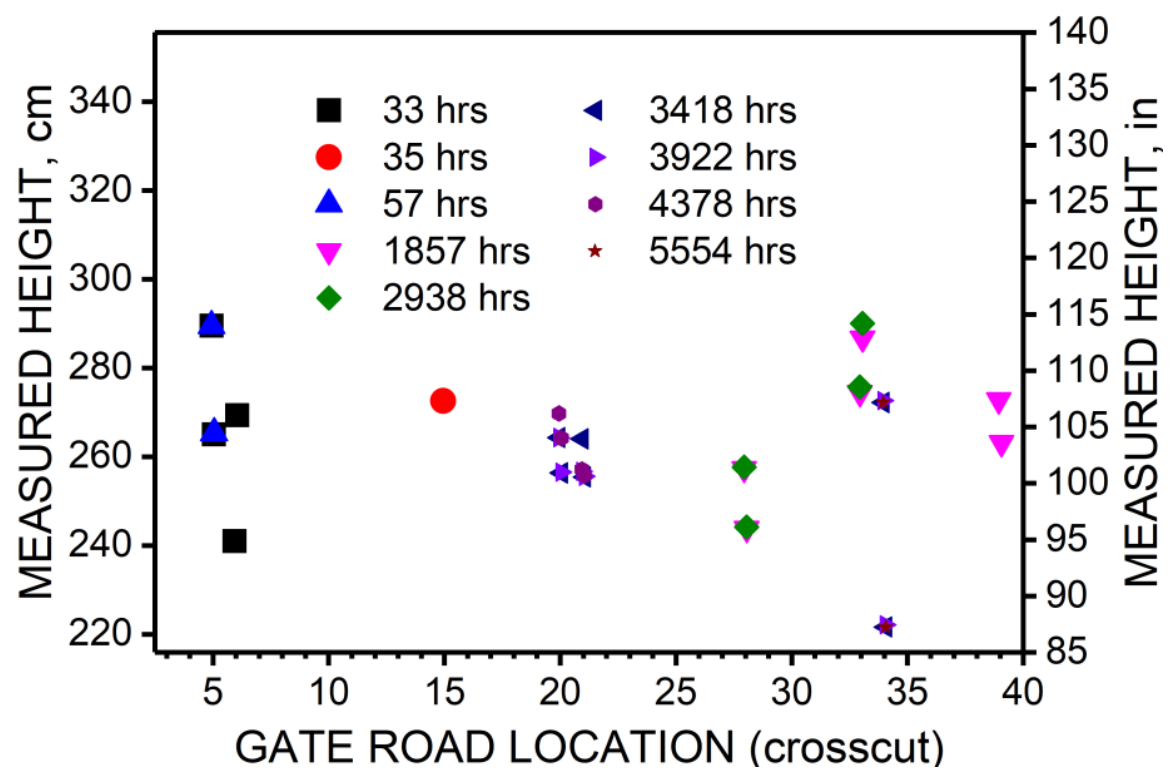

Figure G12. Manually measured entry height (floor anchor to roof anchor) plotted with location, with symbols indicating time of measurement. Measurements near crosscuts 5 and 6 were taken in the B-11 panel tailgate at Mine B. All other measurements were taken in the B-11 panel headgate. 


\section{String potentiometer closures vs. manually measured closures}

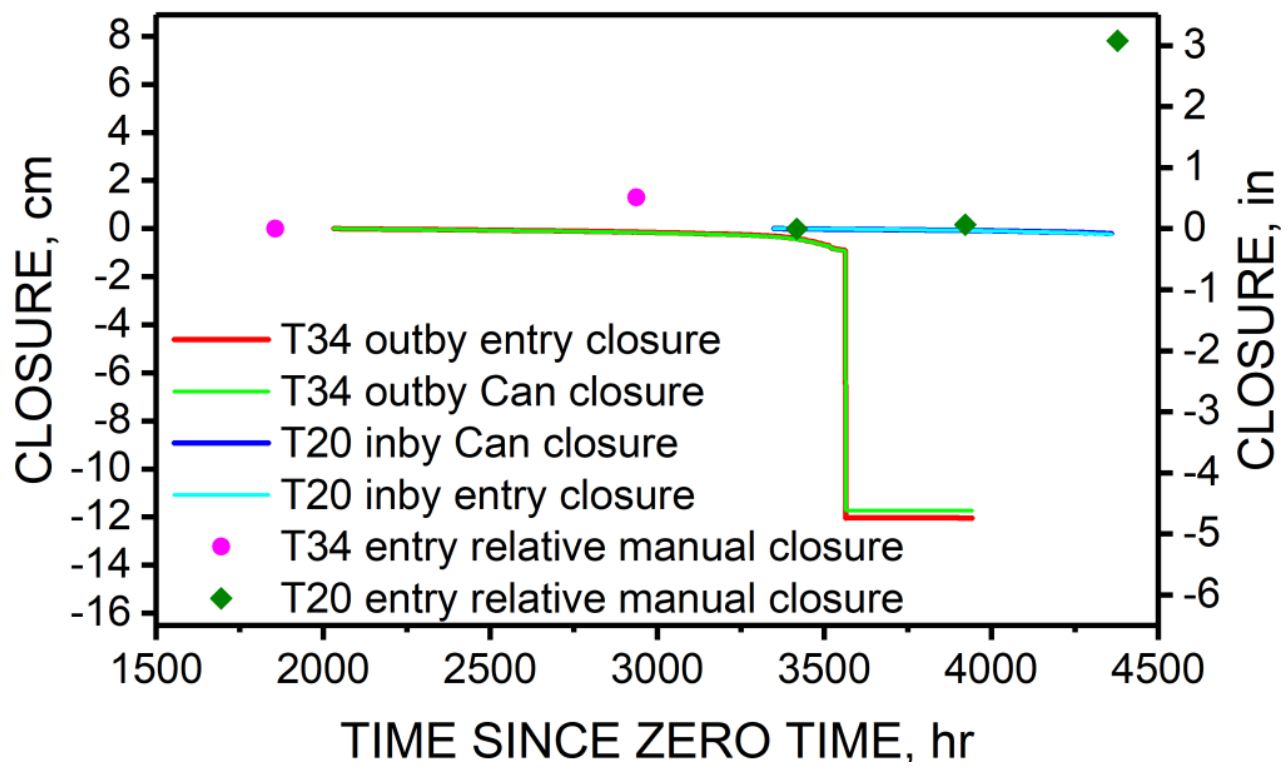

Figure G13. String potentiometer closures versus manually measured entry closures at Mine B. 


\section{Appendix H: Mine B-Miscellaneous Measurements: Ground Condition Surveys, and Roof and Rib Extensometers}

\section{Description}

Measurements shown here are for completeness of the data set, but they add no helpful information for model calibration.

Few ground condition surveys were conducted, and only the gate roads of the B-11 panel were surveyed. Figure $\mathrm{H} 1$ shows the ratings for a survey of the entry \#3 of the tailgate. Figure $\mathrm{H} 2$ shows the ratings in the entry \#3 of the headgate. Although these ratings document the condition of the \#3 entry of each gate road, one or two surveys are not enough to establish trends to pinpoint deterioration of ground conditions resulting from the arrival of mining-induced abutment stress.

Figure H3 shows roof extensometer measurements at the $\mathrm{H} 42$ site in the B-12 headgate/B-13 tailgate. The two extensometers consistently indicate that the majority of roof sag occurred

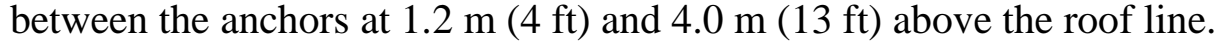

Figure $\mathrm{H} 4$ shows measurements from a rib extensometer at the H42 site. There is very little displacement, and nearly all of it was between the collar and the anchor at $0.6 \mathrm{~m}(2 \mathrm{ft})$ of depth. However, the rib conditions at this particular site were exceptionally good, while within only a few meters all around this site, rib conditions were poor-showing rubblized failure and frequent hourglass profiles. Again, the H42 site was too close to the startup rooms of the B-12 and B-13 panels to be of any use for model calibration. 


\section{B11 tailgate}

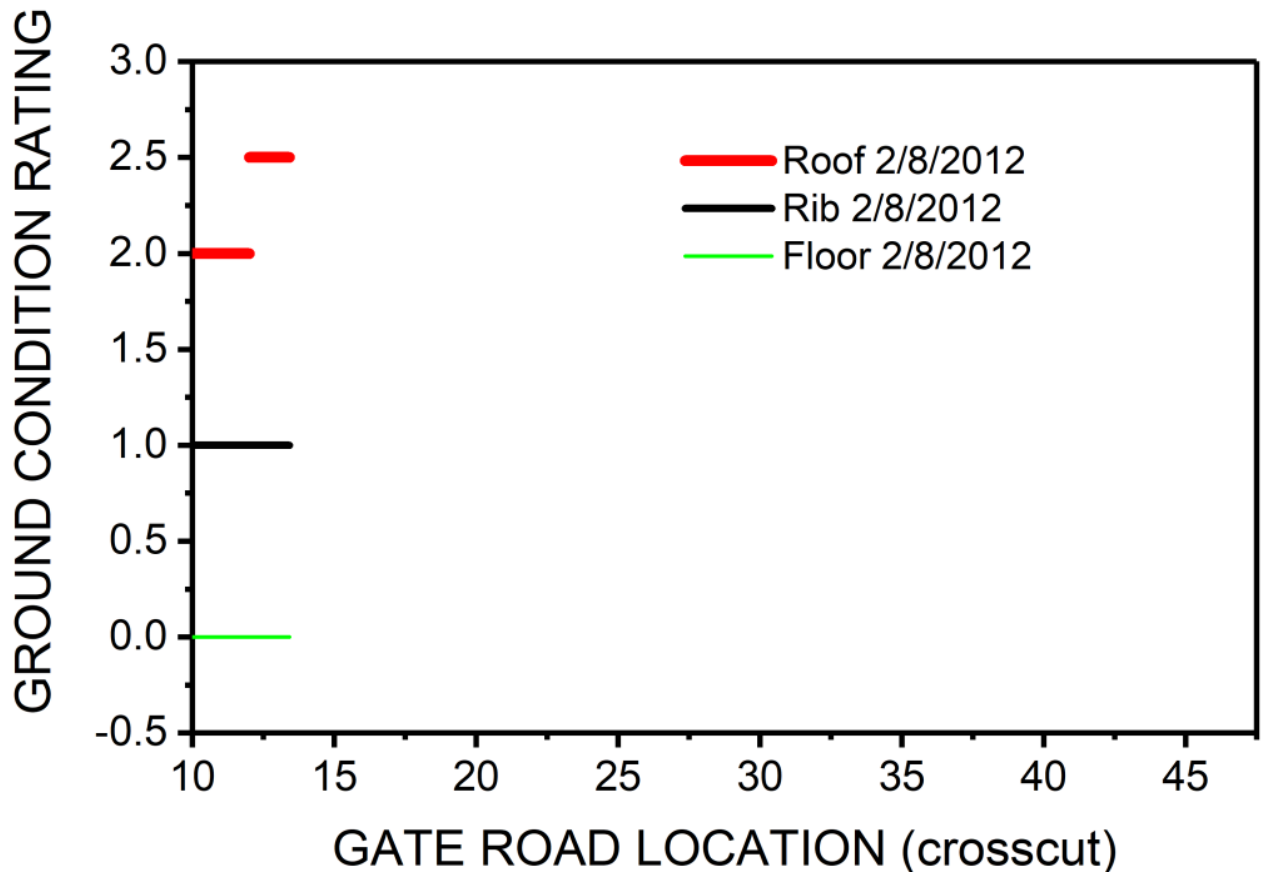

Figure $\mathrm{H} 1$. Ground condition ratings plotted with location in the B-11 tailgate at Mine B. The B-11 panel face was between crosscuts 13 and 14 at the time of this survey.

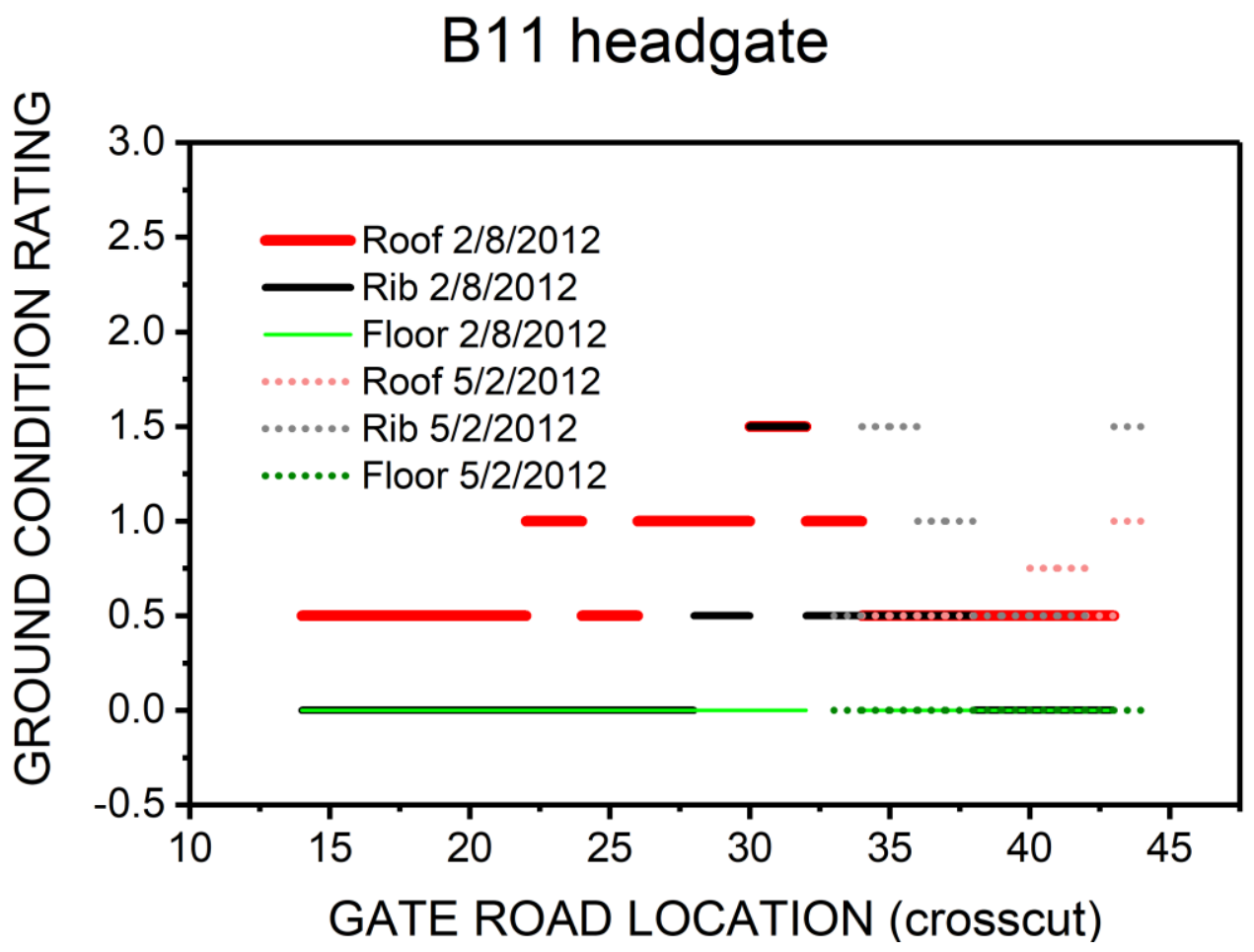

Figure H2. Ground condition ratings plotted with location in the B-11 headgate at Mine B. The B-11 panel had been completed several days earlier at the time of this survey. 


\section{H42 station roof extensometers}

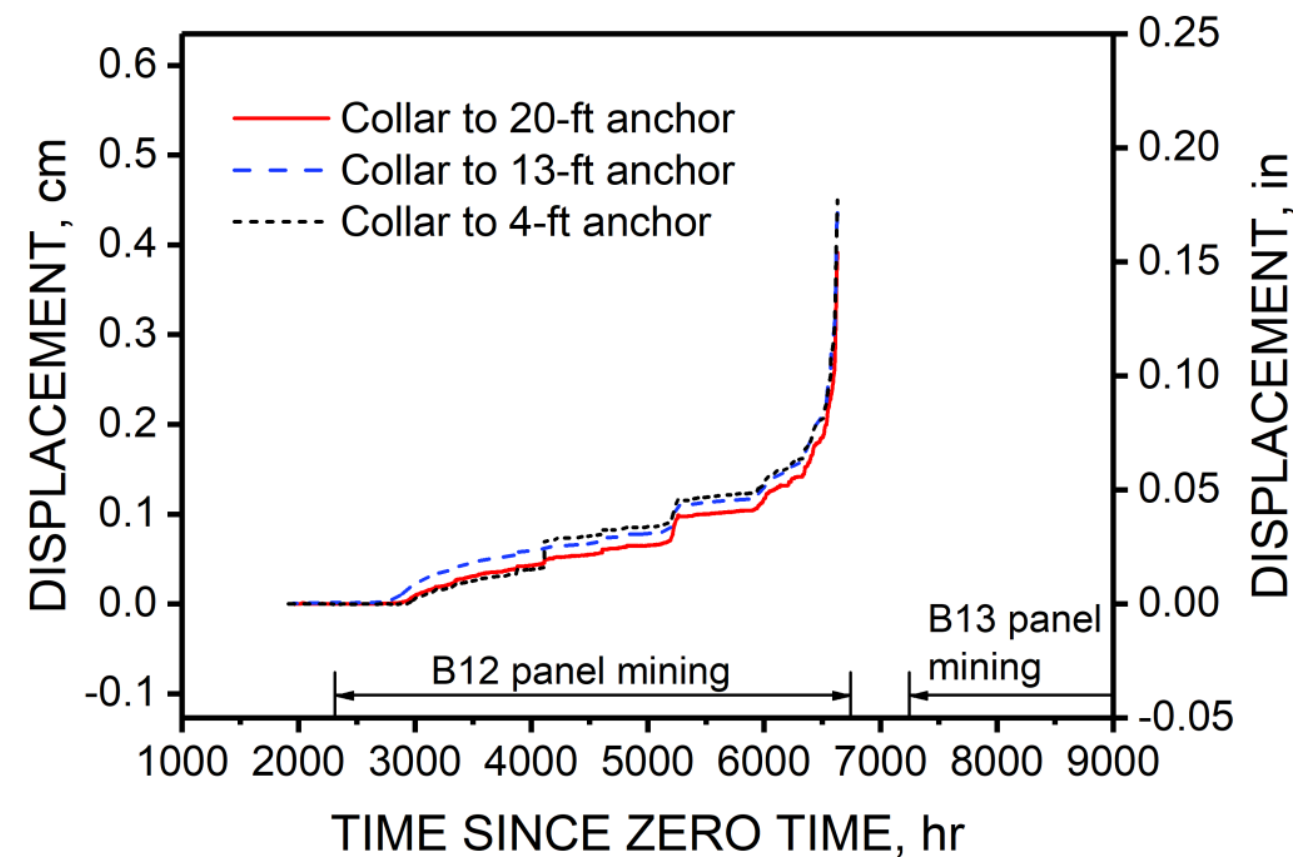

Figure H3. Displacement between collar and roof extensometer anchors at $\mathrm{H} 42$ at Mine B, plotted with time.

\section{H42 station rib extensometers}

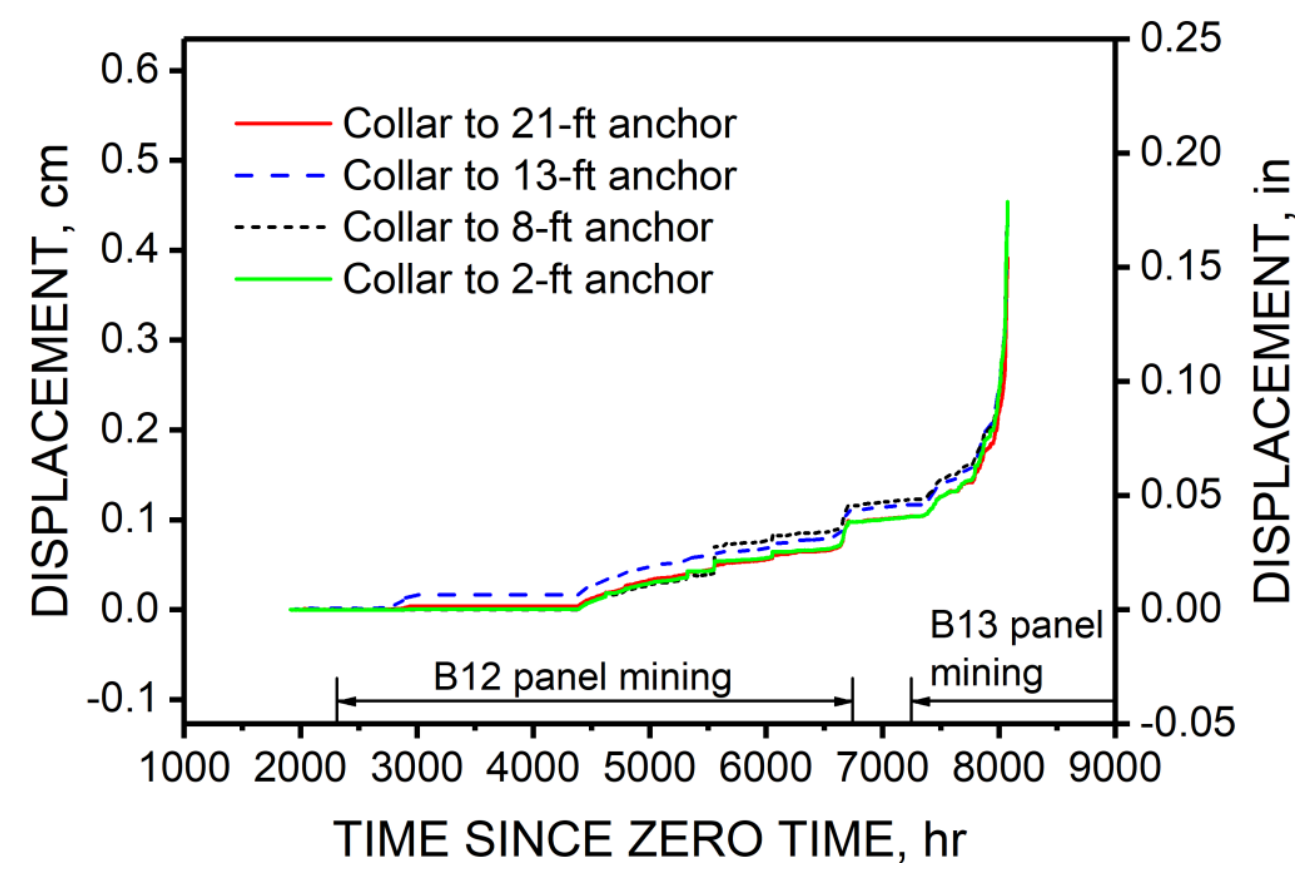

Figure H4. Displacement between collar and rib extensometer anchors at $\mathrm{H} 42$ at Mine B, plotted with time. 
Promoting productive workplaces through safety and health research

DHHS (NIOSH) Publication No. 2020-103

DOI: https://doi.org/10.26616/NIOSHPUB2020103 